\title{
الشرف العالي
}

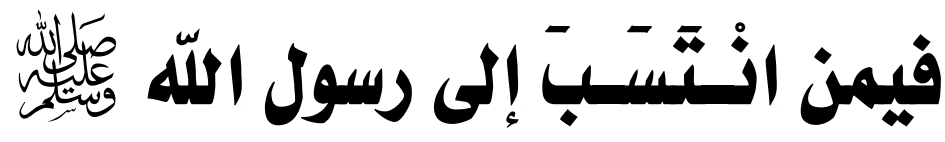

$$
\text { " من الخدم والموالى }
$$

$$
\begin{aligned}
& \text { بقلم دكتور | } \\
& \text { الحسيني يوسف عبد العال أحمد لئد } \\
& \text { هدرس الحديث وعلوهه } \\
& \text { كلية الدراسات الإسلامية والعربية للبنات بالإسكندرية } \\
& \text { جاهعة الأزهر }
\end{aligned}
$$




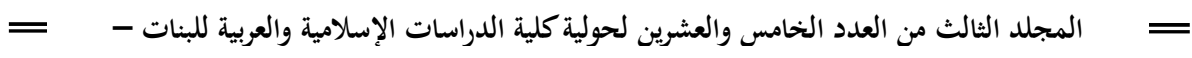

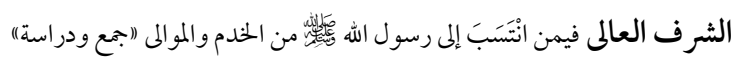

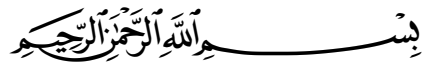

\section{الاقدهة}

إن الحمد لله نحمده ونستعينه ونستغفره، ونعوذ بـاله مـن شـرور أنفسنا

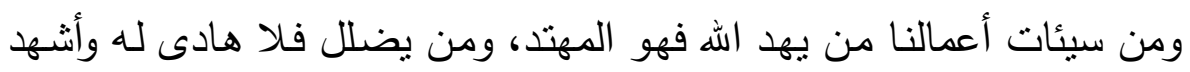

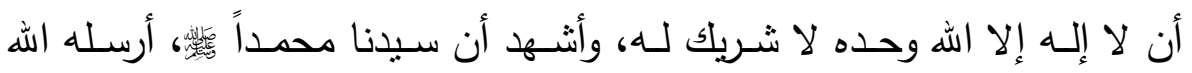

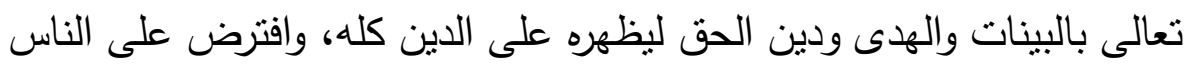

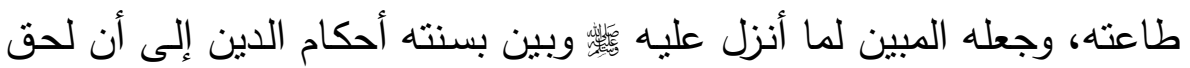

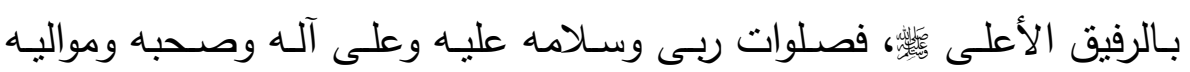
وخدمه وسلم.

\section{وبعد ....}

فإن مرتبة السنة النبويـة فى الحجية تلى القرآن الكريم، إذ هـى مفسرة لنصوصده، ومبينة لمعناه، بتخصيص عامة، وتقييد مطلقه، وتوضيح مشكله، وتعيين مبهمه، وتقسير محكمه، واتباعها واجب كالقرآن الكريم لقوله تعالى:

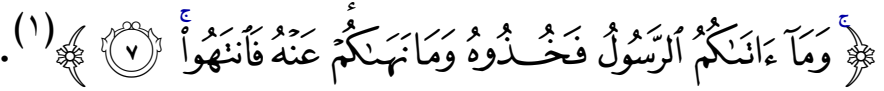

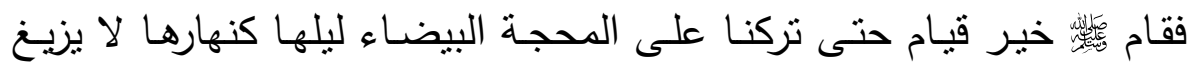
عنها إلا هاللك.

ومسن بعده الصـحابة: الـذين رفعـوا رايـة السـنة فـأعلوا شـأن الروايـة،

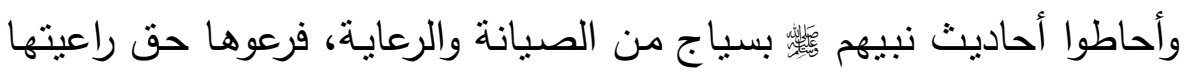
فحفظوها فى الصدور وبلغوها لمن بعدهم بيضاء نقية كما تحملوها وحكموها فى حركاتهم وسكناتهم، وطبقوها فى حياتهم رضى الله عنهم.

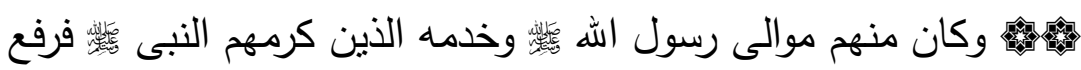

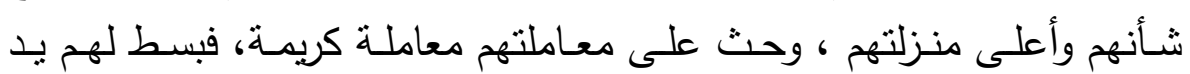

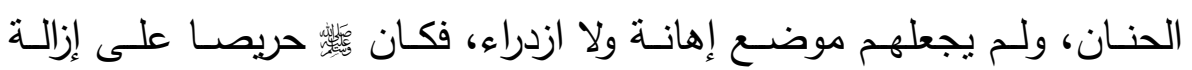




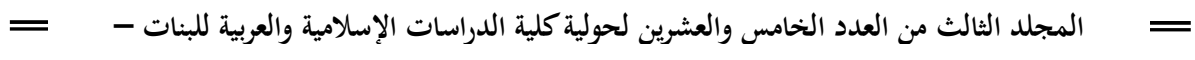

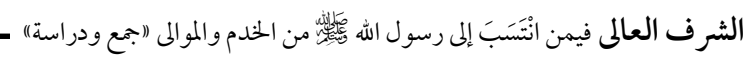

الفوارق بينه وبينهم حتى قبل البعثة، أعتق مولاه زيد بن حارثة وتبناه، وكان

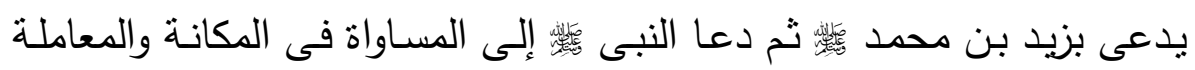

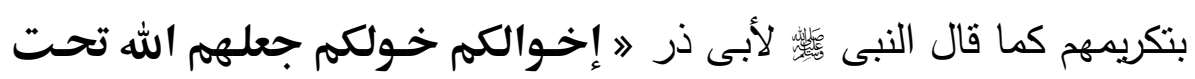

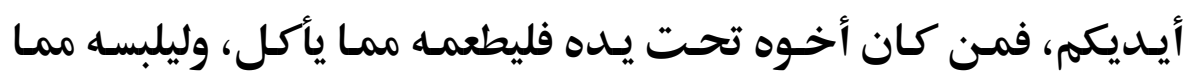
يلبس، ولا تكلفوهم ما يخلبهم فإن كلفتموهم فأعينوهم " في (') فلنَ رفع الله بعض النـاس على بعض فقد أوجب حسن المعاملـة بين الجميع فى معاملـة الموالى والخدم، ونهى عن تكليفه بأعمال تفوق طاقاتهم فما أجل هذا التشربع

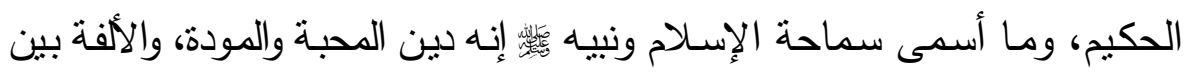
الناس فما أحوجنا له في هذه الأيام.

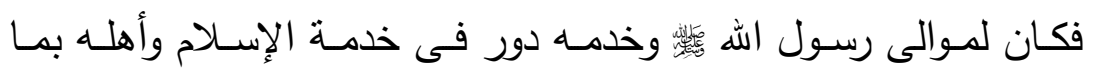
قدموه وبذلوه فى نواحى الحياة، وخاصة فى خدمة السنة النبوبة المطهر تحمـاً وأداءً رضى الله عنهم. فكانت هنالك مدارس ومراكز علمية ودينية وكان على رأسها خادم رسول

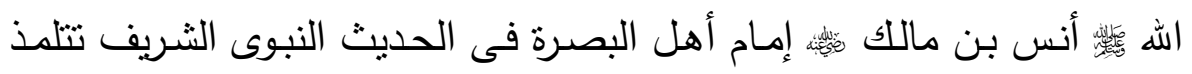
على يديه الكثير

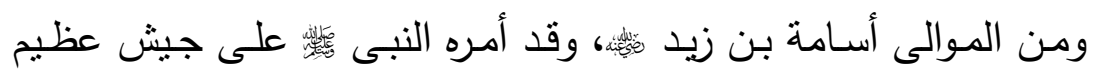

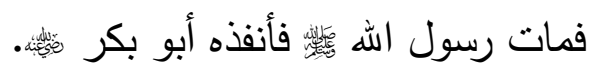

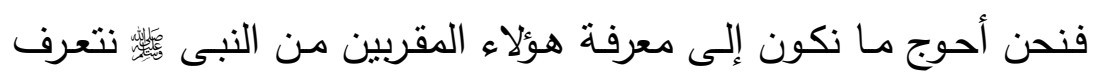

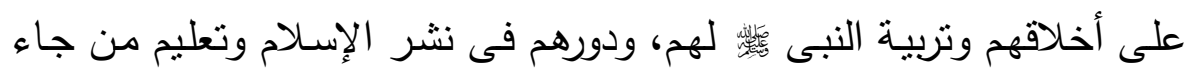
بعدهم من الأمـة أموراً لم بطلـع عليها غيرهم وأخلاق لـ بعرفها سواهم. فهى مناط احترام واجلاءل لهم رضى الله عنهم.

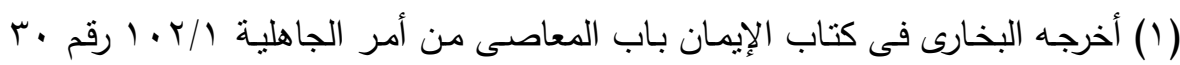

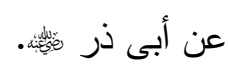




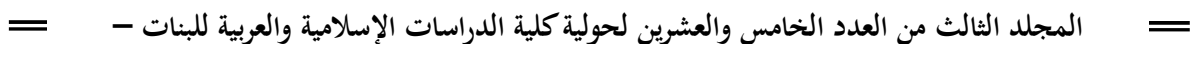

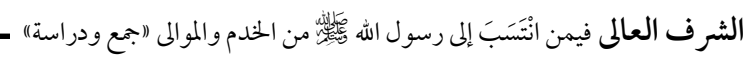

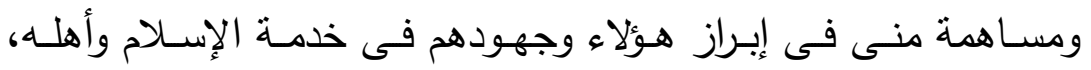

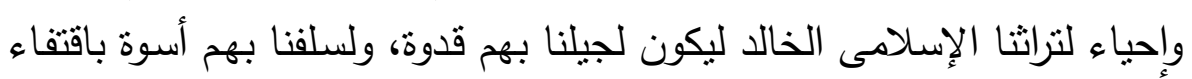

$$
\text { آثارهم انطلاقا من ميراث النبوة. }
$$

أخهو

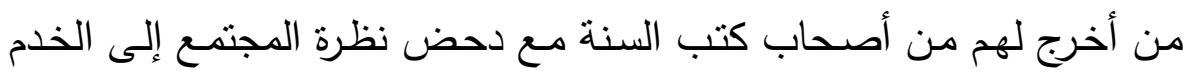

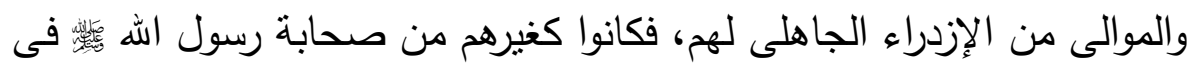

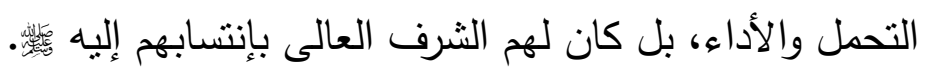

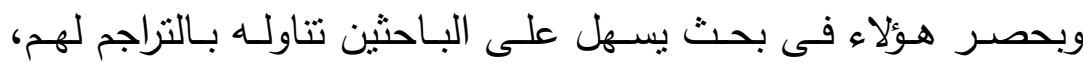

والجوانب المختلفة فى شخصيته فقد قسمت هذا البحث إلى فصلين:-

\section{الفصل الأول:-}

\section{التعريف بالموالى وفيه مبحثنان:-}

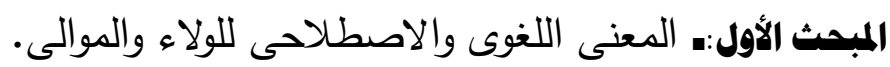

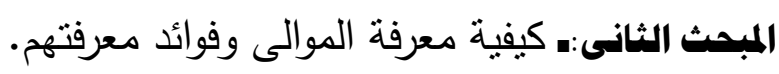

الفصل الثانى:-

موالى رسول الله

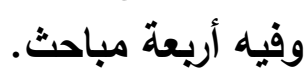

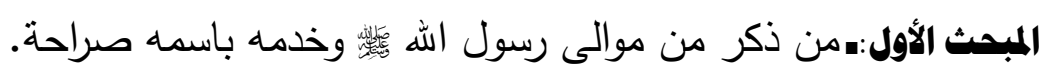

المبحث الثانى:ـ من ذكر من موالى رسول الله وخدمه بكنية أو لقب.

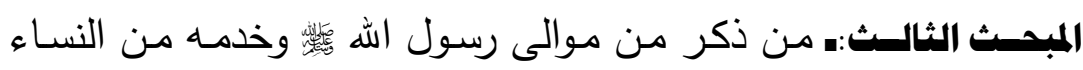

$$
\text { باسمها صراحة. }
$$

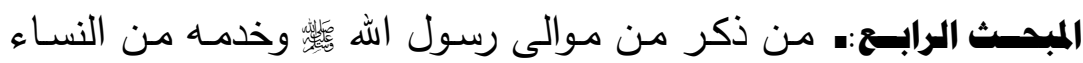

$$
\text { بكنية أو لقب. }
$$

الخاتمة، فهرس المصادر والمراجع، وفهرس الموضوعات. 


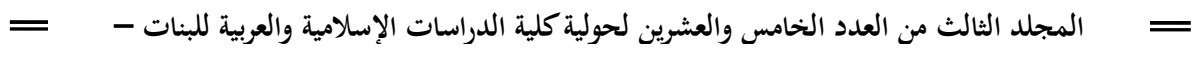

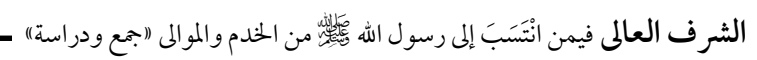

\section{هنهبى فى هذا البحث:.}

\section{اتبعت فى هذا البحث المنهج الأتى:-}

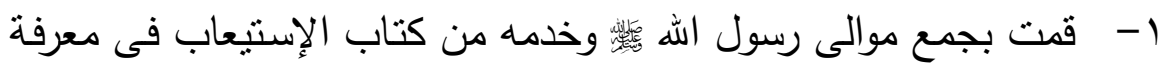

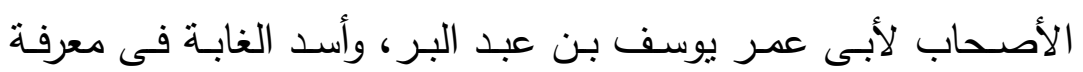

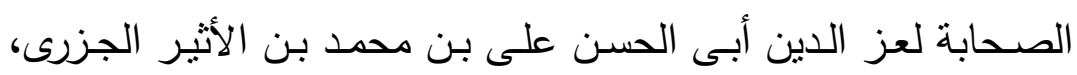

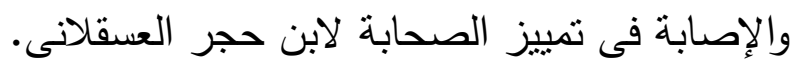

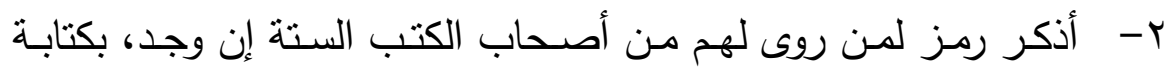
اسمه، والصفة التى اتصف بها فى أعلى الصفحة.

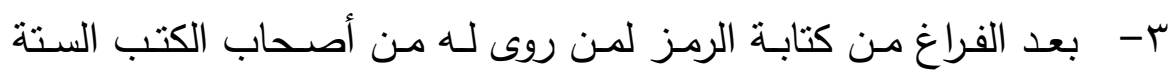

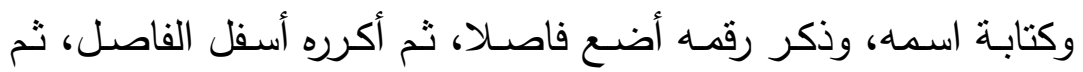
أترجم لهم، مع التتصيص على أقوال من ذكر أنه مولى رسول الله فئس

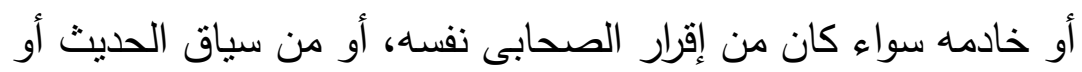

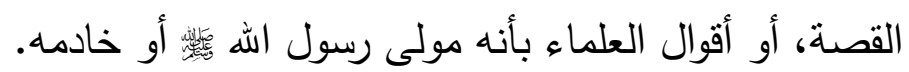

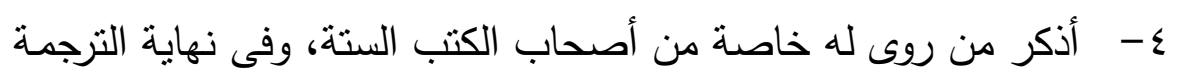

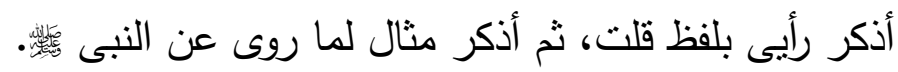

والله أسأل أن يوفقنى لإتمام هذا العمل بحا يرضيه وصلى الله على سيدنا حممد و آله ومواليه وخدمه وسلم.

د /الحسينى يوسف عبد العال أحمد 


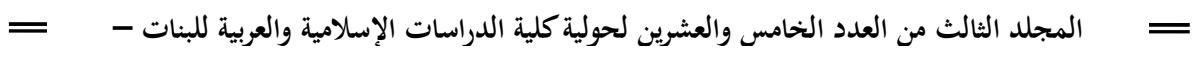

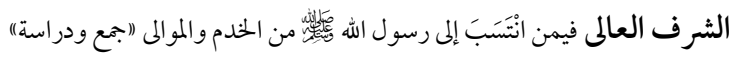

\section{الفصل الأول

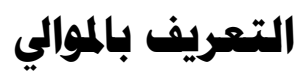 \\ المبحث الأول البمرل \\ المعنى اللغوى والإصطلاحي للاولاء والموالي}

المعنى اللغوى للولاء والموالي (').

من خلال البحث فى مادة " ولى " ومشتقاتها فى قواميس ومعاجم اللغة

العربية اتضح لى معان كثيرة منها:-

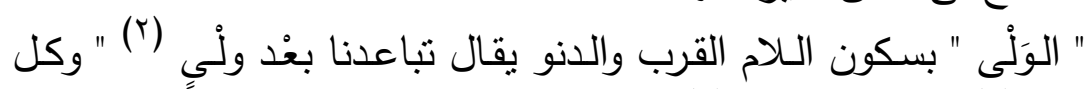

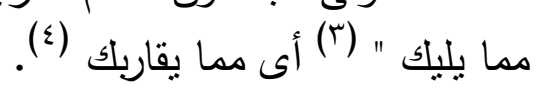

وولى المرأة: من يتولى عقد النكاح عليها ولا يدعها تستبد عقد النكاح

من دونه، وولى اليتيم: الذى يلى أمره ويقوم بكفايته (0)

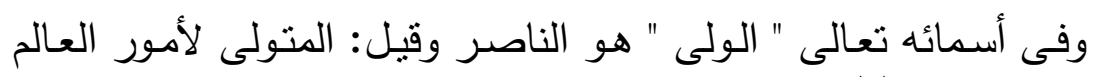

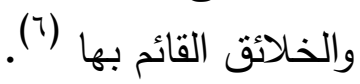

(1) لسـان العرب لابن منظور 1/1/ • ـ مـادة ولى ط صـادر بيروت، مختار الصحاح

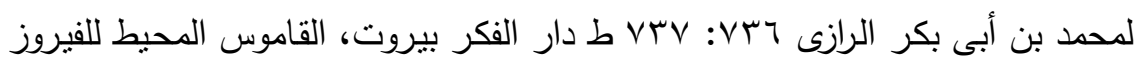

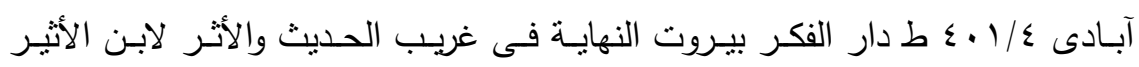


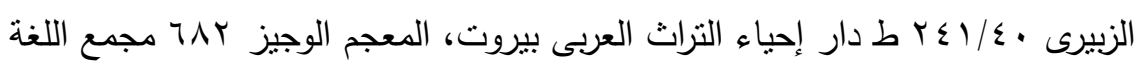

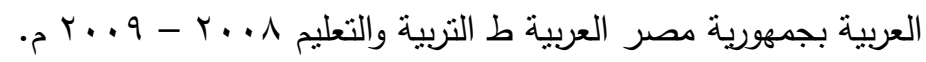

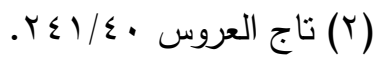

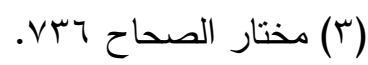

(؛) أخرجه البخارى "بفتح البارى" كتاب الأطعدة باب كل مما يليك 0/90 0 حديث رقم

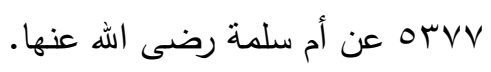

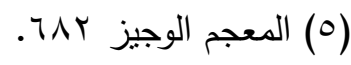

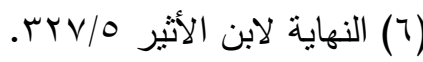




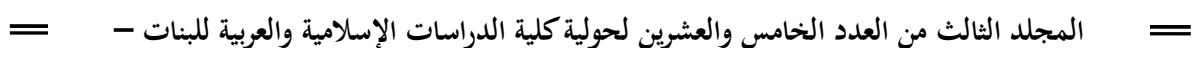

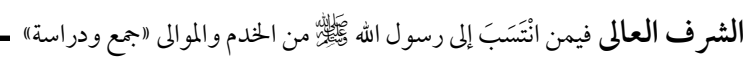

والولى له معان كثيرة: فمنها: " المحب " وهو ضد العدو : اسم من ولاهُ

ومنها " الصديق " ومنها " النصير " من والاه إذا نصره.

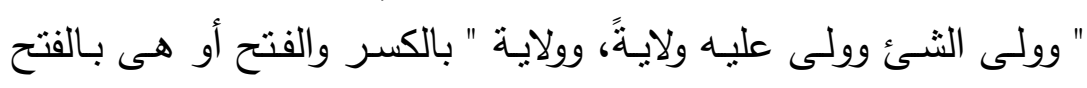

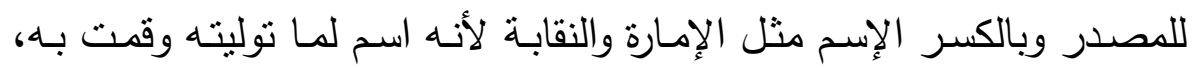
وقيل الولاية بالكسر الخطة والإمارة، وقال ابن السكيث: الولاية بالكسر السلطان

وكأن الولاية تشعر بالتدبير والقدرة على الفعل، وما لم يجتمع ذلك فيها

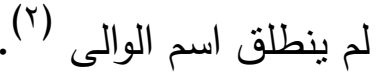 \\ قال ابن الأثير:-}

وقد تكرر ذكر " المولى " فى الحديث وهو اسم لما يقع على جماعة

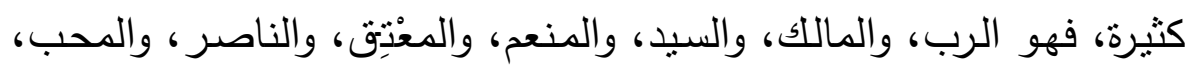

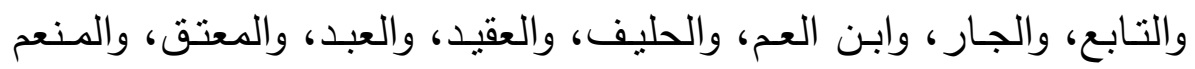

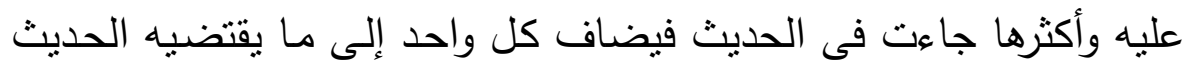

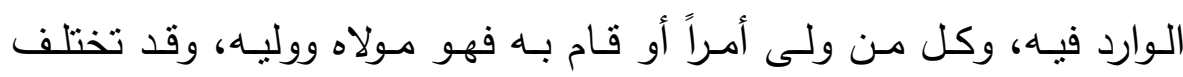

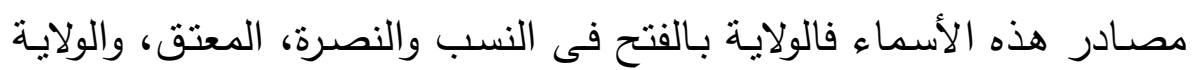

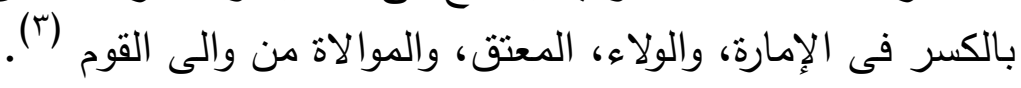
والموالي:- بالير.

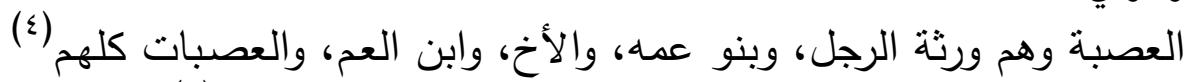

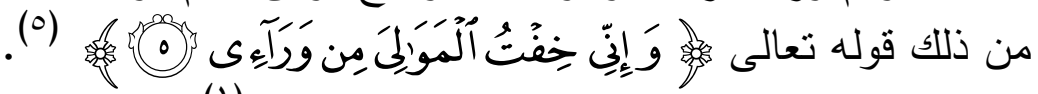
وقوله ذأس

$$
\begin{aligned}
& \text { (1) تاج العروس • • (1) }
\end{aligned}
$$

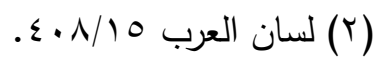

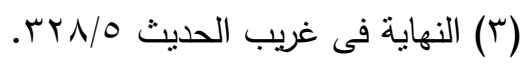

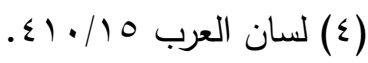

$$
\begin{aligned}
& \text { (0) سورة مريم آية رقم } 0 .
\end{aligned}
$$




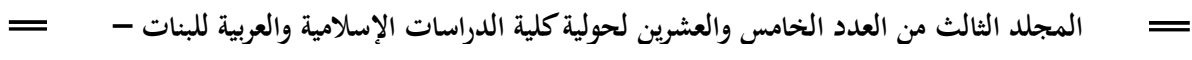

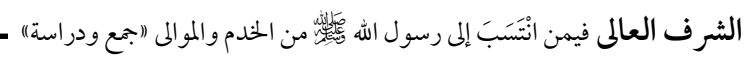

" والموالاة " ضد المعاداة، ويقال " والى " بينهما " ولاء " بالكسر أى

تابع " وتوالى " عليهم شهران تتابع (r)

- أقول:

نستخلص من هذه الأقوال فى مادة " الولى " ومشتقاتها أنها تدور حول

السيادة والقرابـة، والنصـرة، والإسترقاق، وأنها من الأضداد ؛ وذلك لأنها تدل

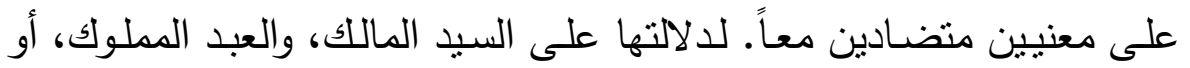
على المنعِم والمنعَم عليه.

\section{والمهنى الاصطلاحى للاولاء والموالي:-}

لقد اكتسب " المولى " معنى اصطلاحيا عند مؤرخى الإسلام قصدوا به:كل من أسـلم من غير العرب سواء استرق أو لم يسترق لأنهم إمـا أن الن موته يكونوا فى أصلهم أسرى حرب استرقوا ثم اعتقوا فصاروا موالى، وامـا أن يكونوا من البلاد المفتوحة وهؤلاء حينما بسلمون ينضمون إلى العرب وبتحالفون معهم

لكى يعتزوا بقولهم فيصبحوا موالى بالحلف والموالاة (r). وقال الطحان أن المولى اصطلاحا:-

هو الثخص المحالف، أو المعتق أو الذى أسلم على بد غيره (ء). قات:وون هنا يتضح لنا الفرق بين الموالى، والخدم.

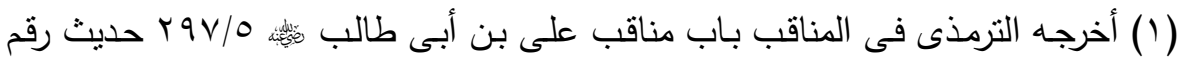

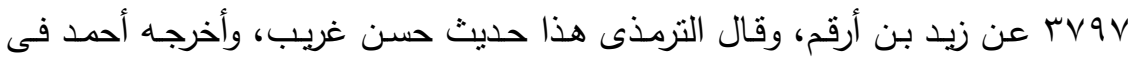

$$
\begin{aligned}
& \text { مسنده / / / عن زيد بن أرقم منله. } \\
& \text { V VY (Y) مختار الصحاج }
\end{aligned}
$$

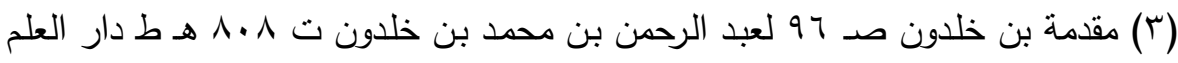
بيروت.

(ع) تيسير مصـلح الحديث صـ ، بr للدكتور /محمود الطحسان مكتبـة المعـارف والنشـر

$$
\text { والتوزيع والرياض - السعودية. }
$$




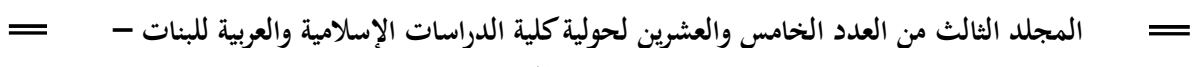

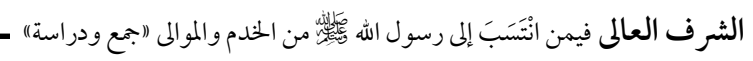

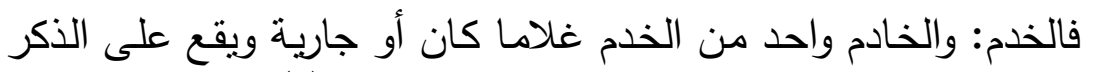

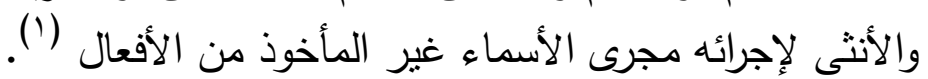

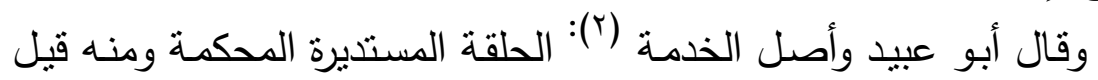

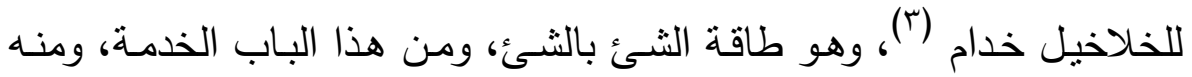

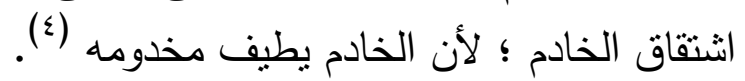
وعلى هذا يكون الخدم من الأحرار ، والموالى يكونون من الأرقاء. 第然然

( (1) تيسير مصطلح الحديث صـ • • r للدكتور/محمود الطحان مكتبة المعارف والنشر

$$
\begin{aligned}
& \text { والتوزيع وبالرياض - السعودية. }
\end{aligned}
$$

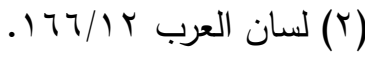

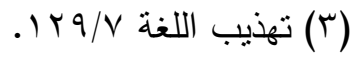

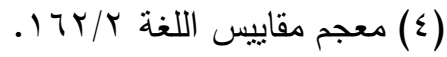




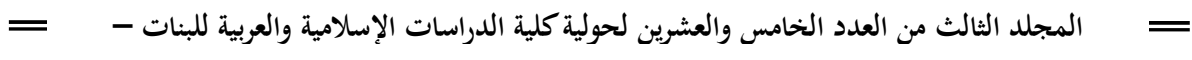

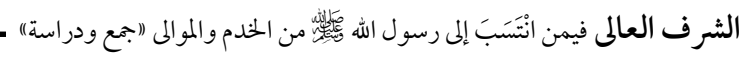

\section{المبحث الثانى

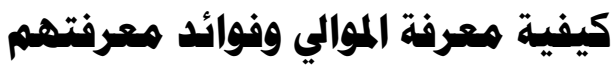 \\ إن معرفة موالى العتق تتم بطرق مختلفة منها:-- \\ أولا:ـ إقرار المولى نفسه بما بدل على ولائه مثل:-}

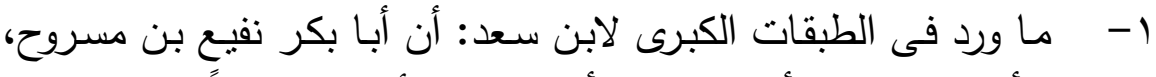

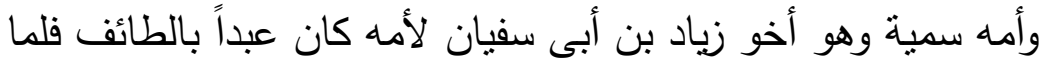

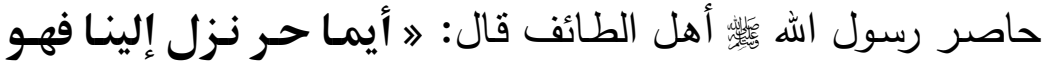

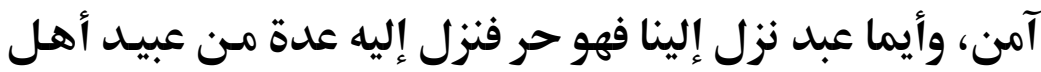

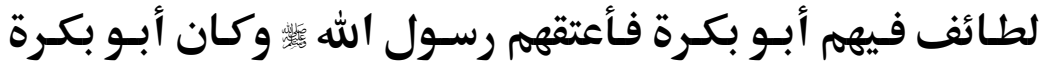

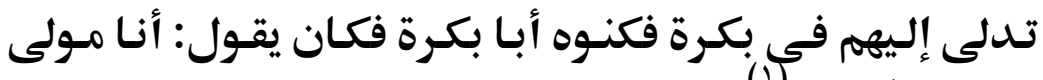

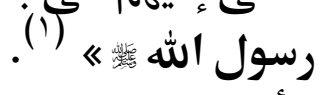

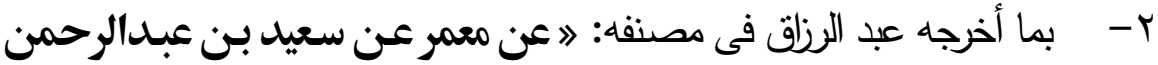

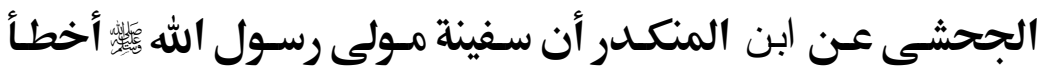

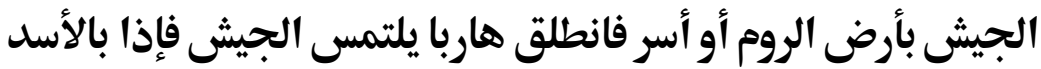

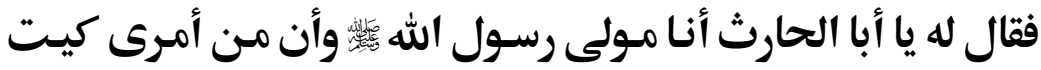

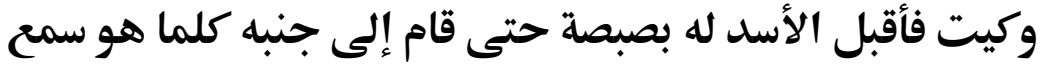

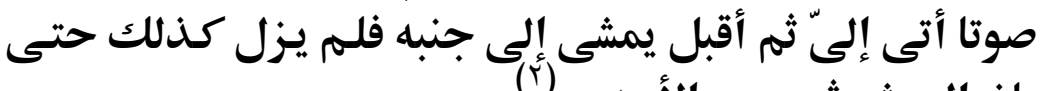

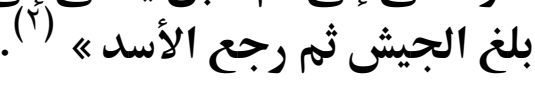

(1) أورده ابن سعد فى الطبقات الكبرى 10/V1، وأورده ابن الجوزى فى كتاب تتوير الغبش

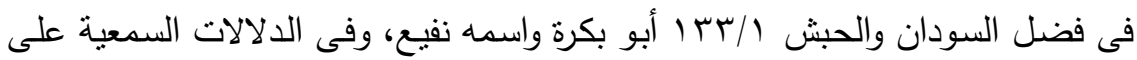

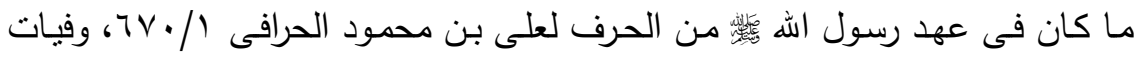

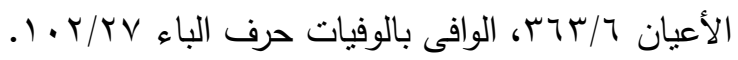

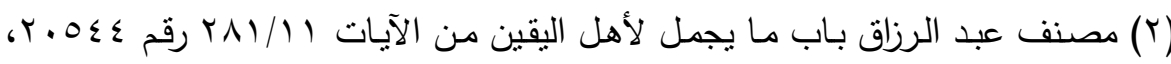

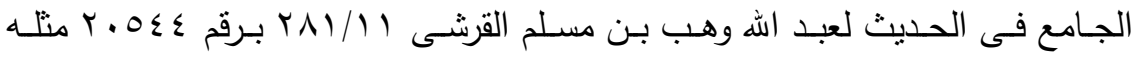

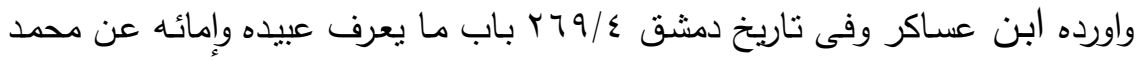

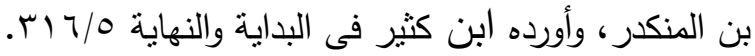




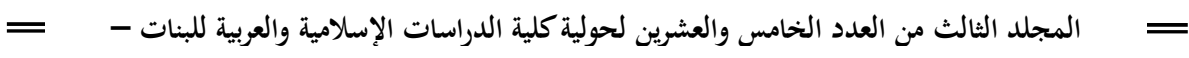

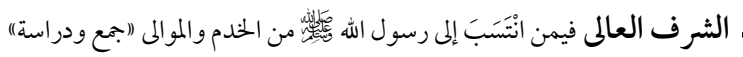

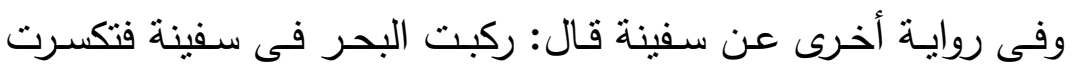

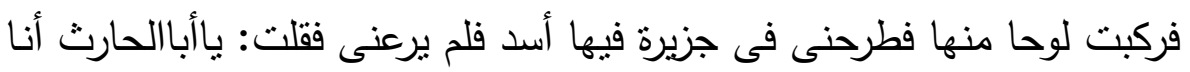

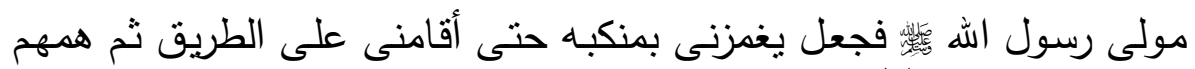

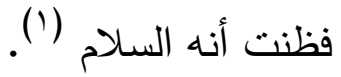

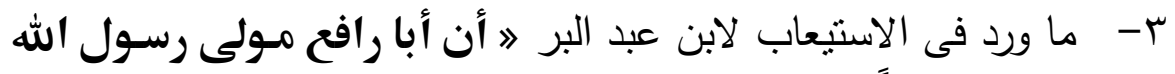
ئاس

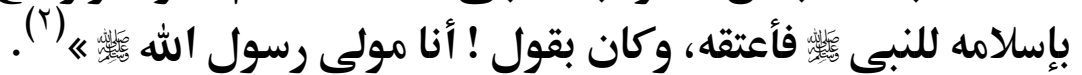

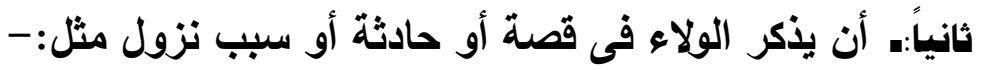

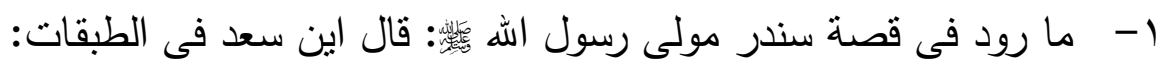

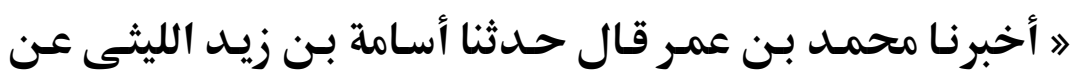

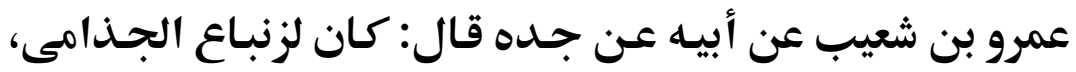

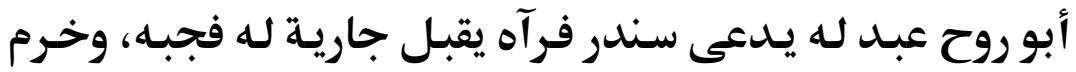

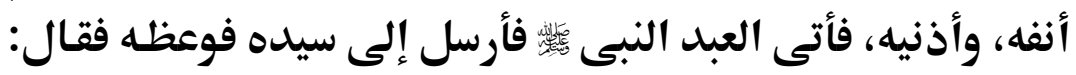

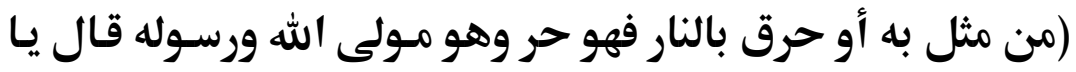

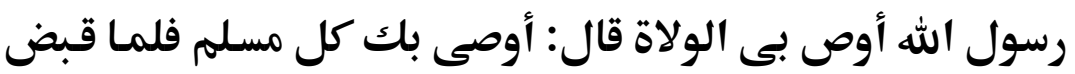

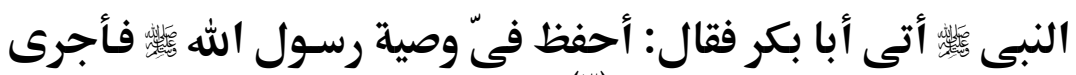
عليه القوت حتى مات....) « (r).

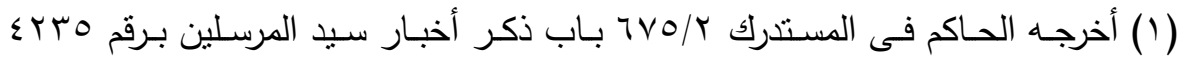

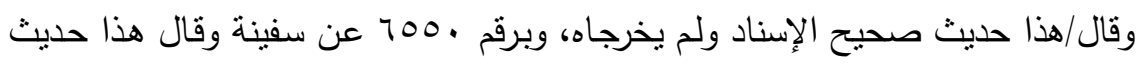
صحيح على شرط مسلم ولم بخرجاه.

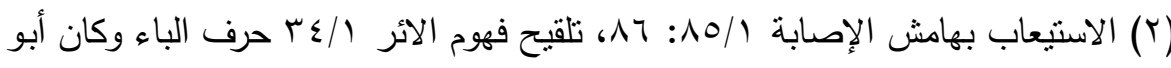

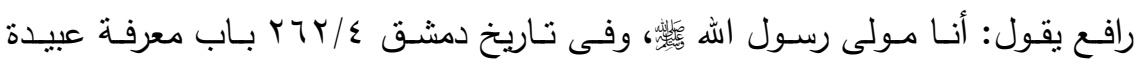
وإمانه...

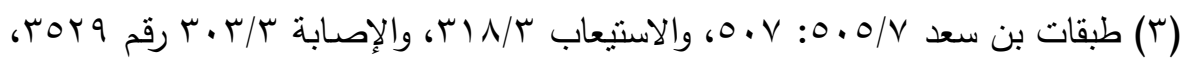

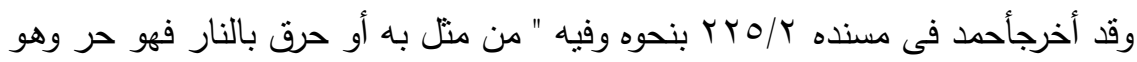
مولى الله ورسوله قال: فأنى برجل قد خصى يقال له سندر «. 


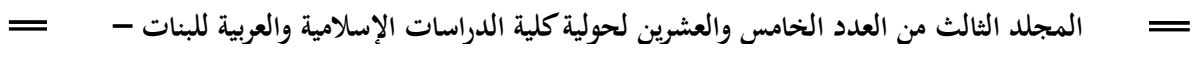

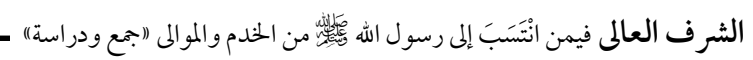

r- بما رواه بـن سـد (')، عن ابن عباس رضـى الله عنهما قـال حدنثى

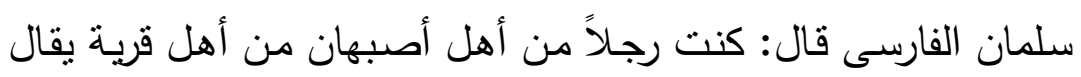

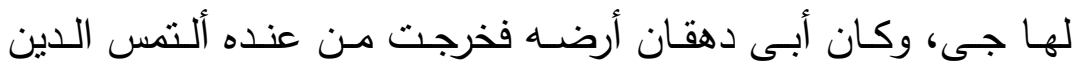

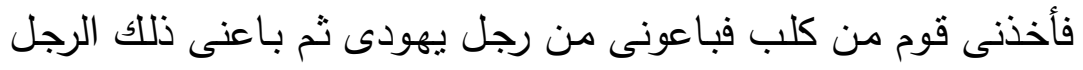

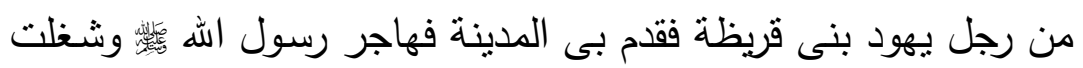

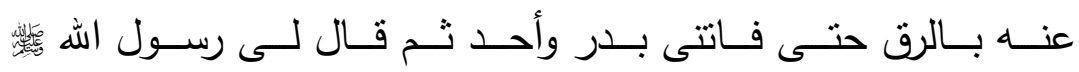

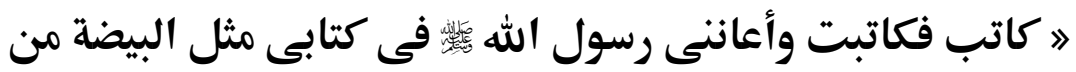

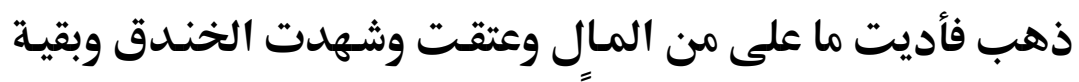

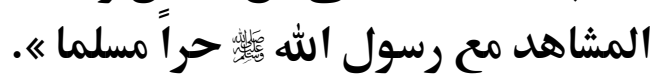

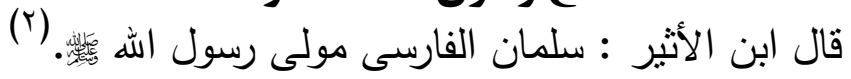

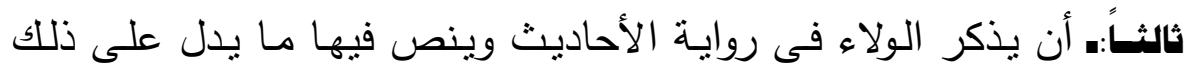
منل:1- أخرج البخارى بسنده قال حدثتا أبو نعيم حدثنا عبد الواحد بن أبى أيمن

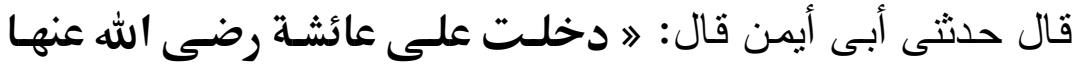

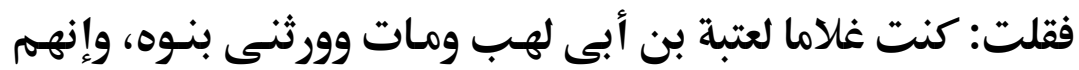

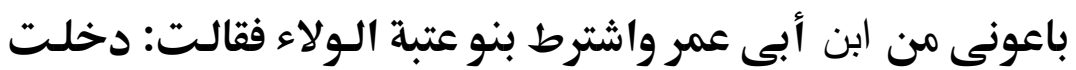

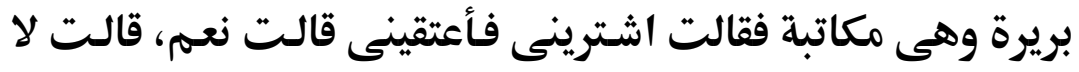

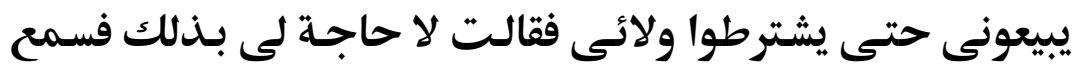

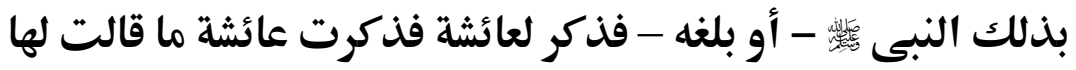

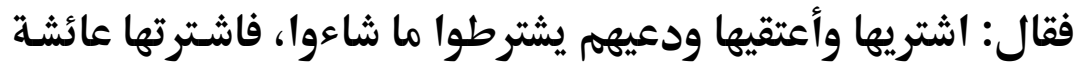

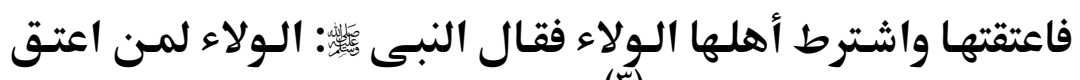

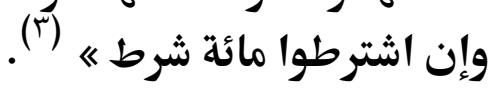

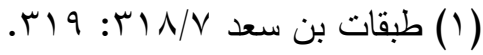

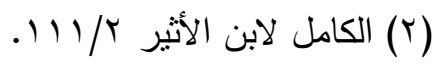

(r) أخرجه البخارى "بفتح البخارى" فى كتاب المكاتب باب إذا إنال الشترنى وأعتقنى فاشتراه

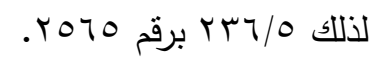




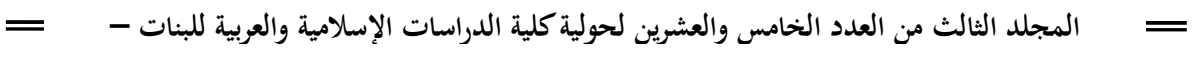

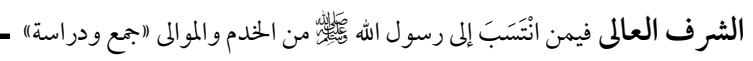

r- - وأخرج البخارى بسنده قال حدثنا أيوب بن سليمان قال حدثنا أبو بكر

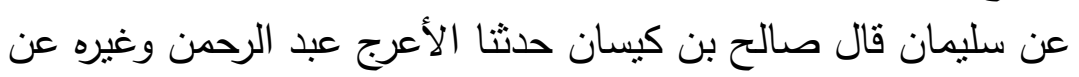

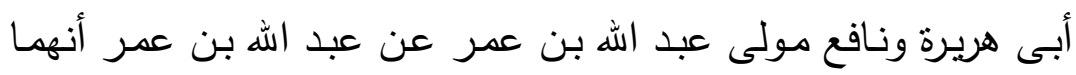
حدثاه عن رسول الله هئس

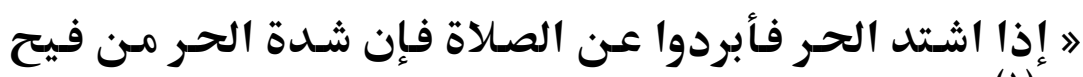
جهنم " (1)

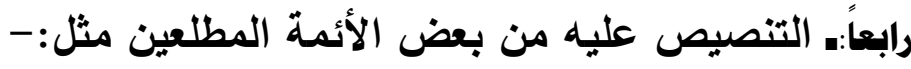

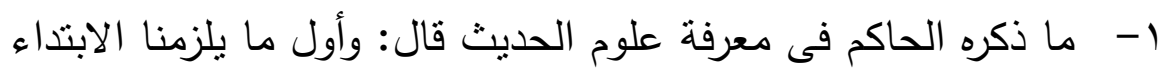

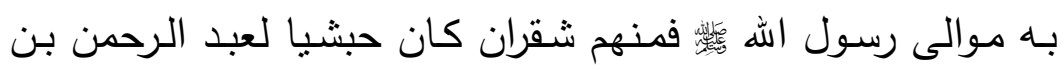

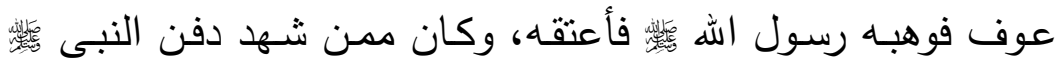

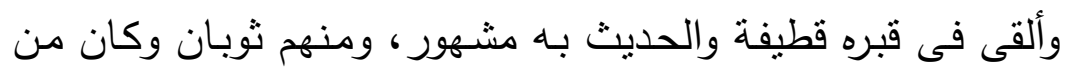

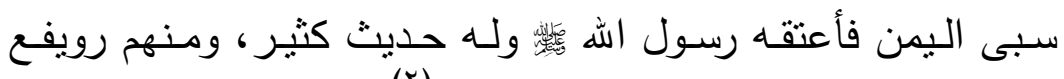

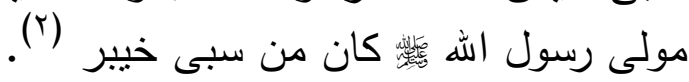
r- ـ وذكر ابن كثير أسماء أهل بدر وذكر فيهم: " أنسـة الحبشى مولى له رسول الله

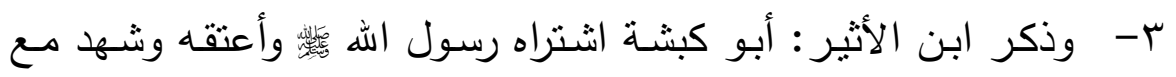

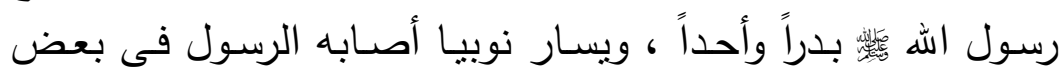

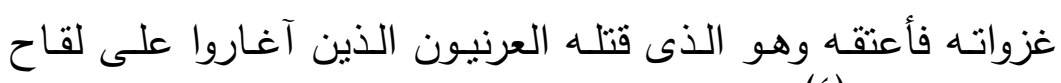
رسول الله

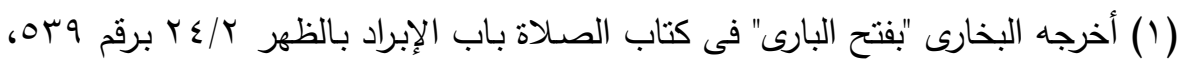

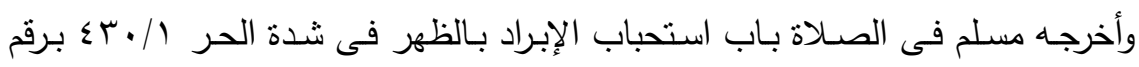
ا 17 مثله.

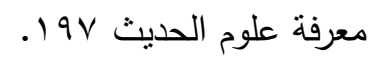

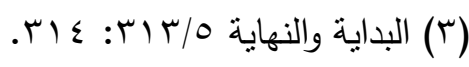

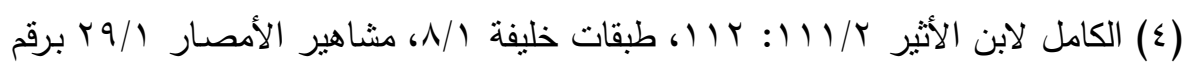




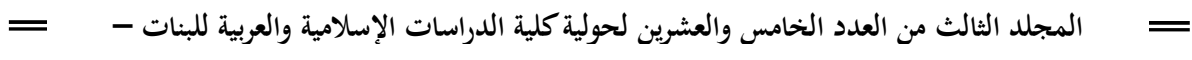

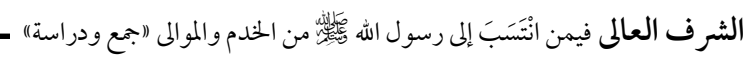

\section{أنواع الموالي في الإسلام عاهة ثلاثة وهى (1)":}

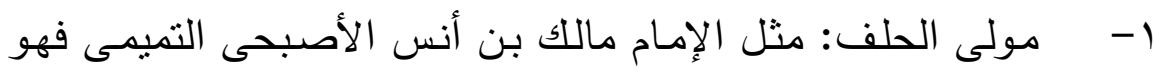

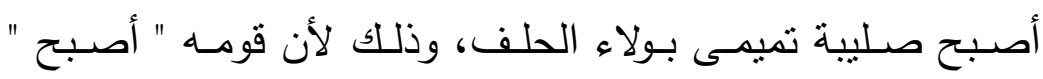
موالى لتيم قريش بالحلف.

r- مولى العثاقة: مثل أبو البخترى الطائى التابعى واسمه سعيد ابن

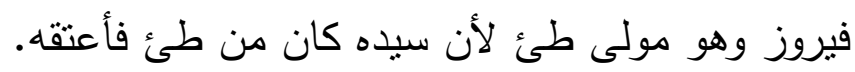

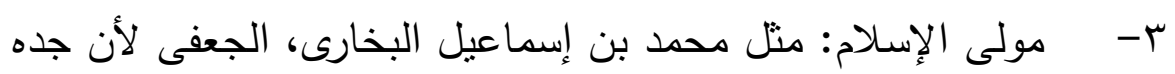

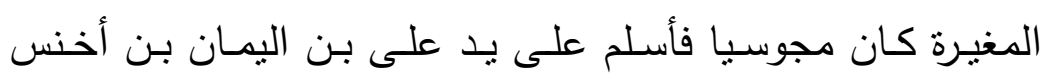
الجعفى فنسب إليه. - الئان

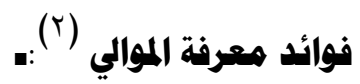

1- الأمن من اللبس ومعرفة المنسوب إلى القبيلة نسباً أو ولاء ومن ثم

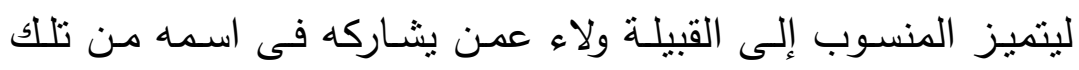

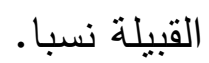

r- حتى لا يترتب على ذلك خلل في الأحكام الثـرعية فى الأمسور

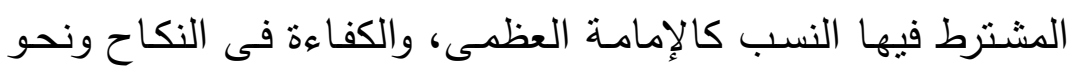

ذللك.

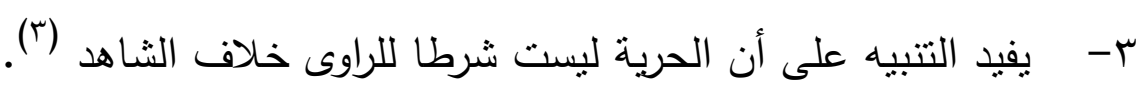

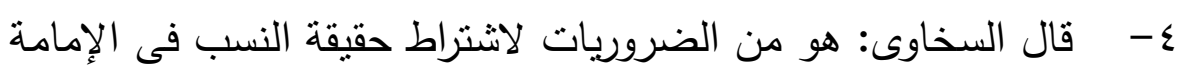

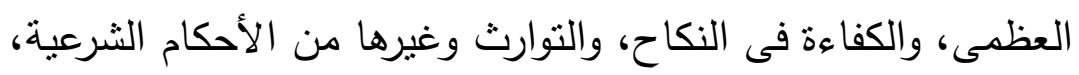

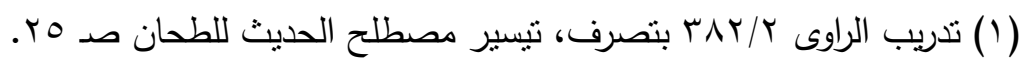

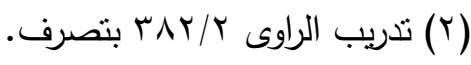

$$
\begin{aligned}
& \text { (r) رسوم التحديث فى علوم الحديث الحاوى والخمسون / V ابتصرف. } \\
& 19
\end{aligned}
$$




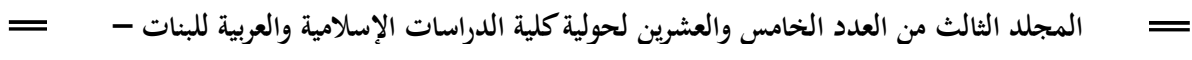

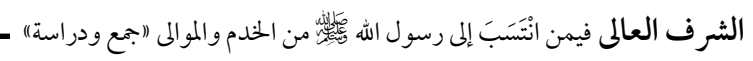

ولاستحباب التقديم به فى الصـلاة وغيرها، وإن كان ورد فى الحديث

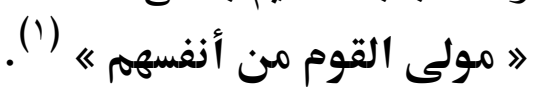

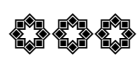

(1) فتح المغيث الموالى من العلماء والرواة / / 9 ب، توجيه النظر إلى أصول الأثر باب ذكر موالى رسول اله له

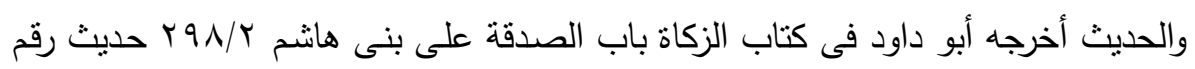

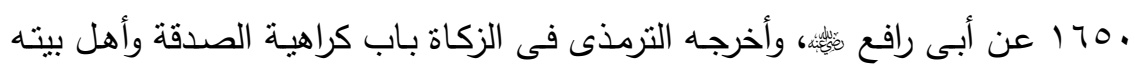

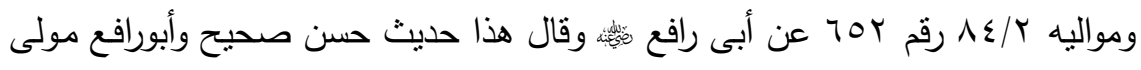
النبى 


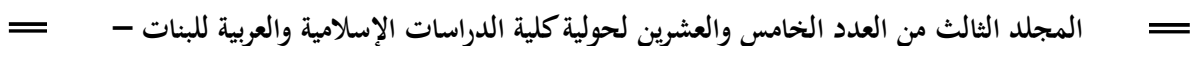

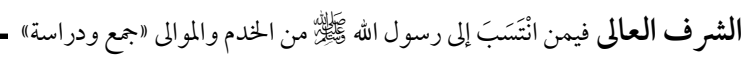

\section{النصال الثانى

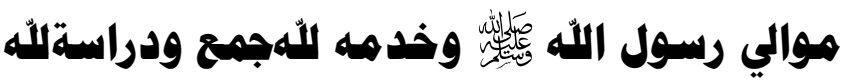 المبحث الأول وند}

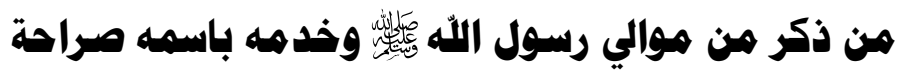

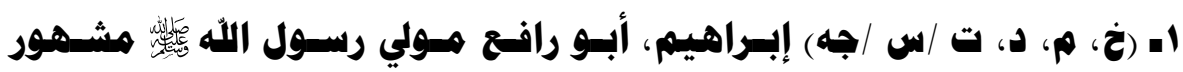

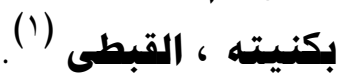

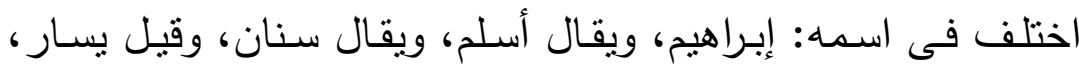

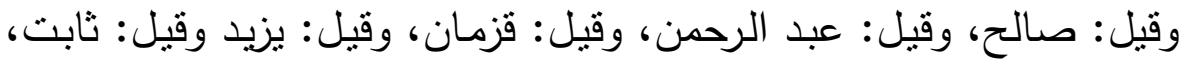

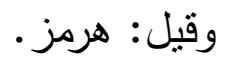
ولقبه: بريه، وهو تصغير : إبراهيم، ونسبه القبطى. وكان إسلامه قبل غزوة بدر ولم يشهدها، وشهد أحداً وما بعدها. روى عن النبى وهي

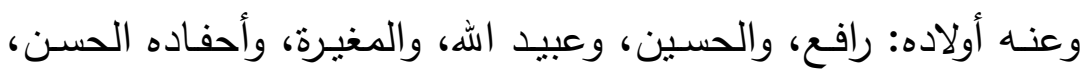

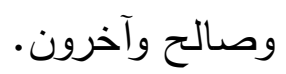

قيل: كان مولى للعباس بن عبد المطلب فوهبه للنبى فئس فأعتقه النبى 

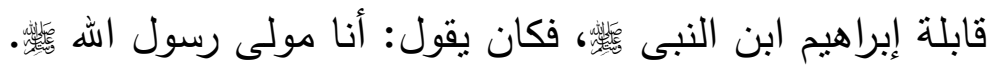

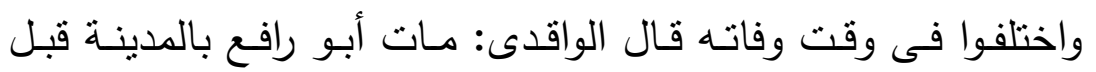
عثمان بيسير أو بعده، وقال ابن حبان: مات فى خلافة على بن أبى طالب أب أبه

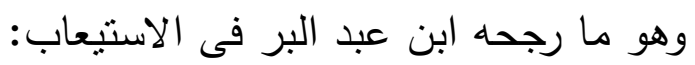

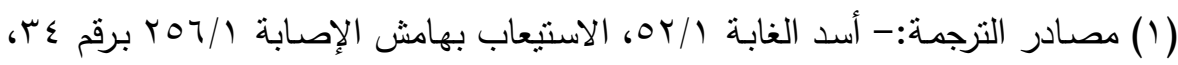

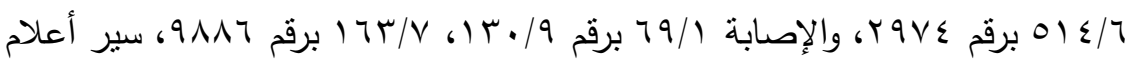

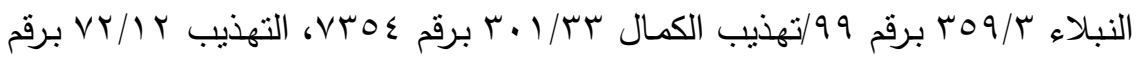

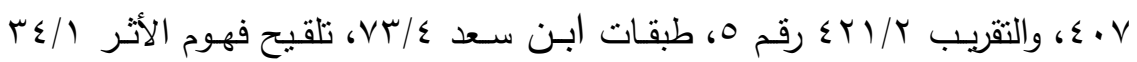
حرف الباء. 


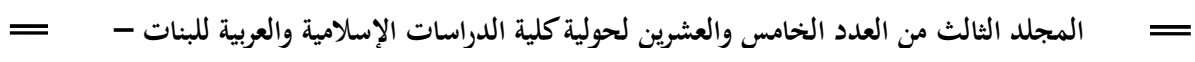

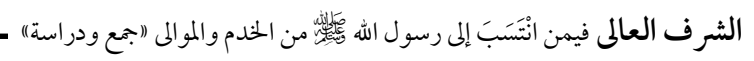

قلت: إبراهيم أبو رافع نئئه روى له أصحاب الكتب الستة، ونص عليه

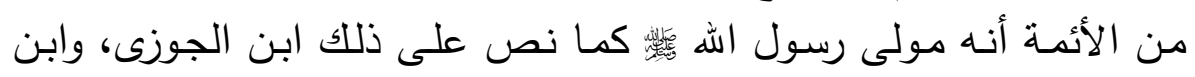

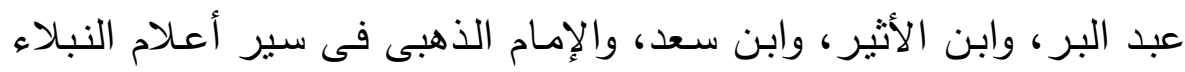

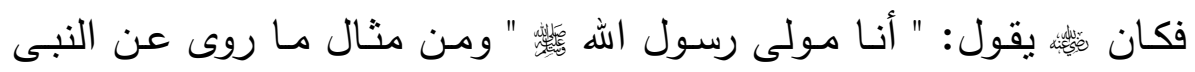
- : 䠛

1- ما أخرجه الإمام مسلم رحمه الله تعالى بسنده قال حدثنا قتيبة بن

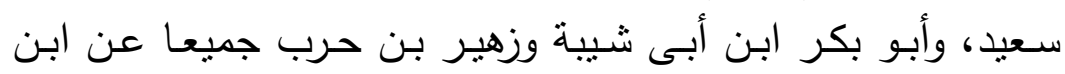

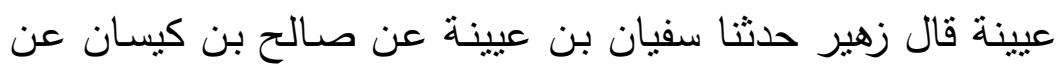

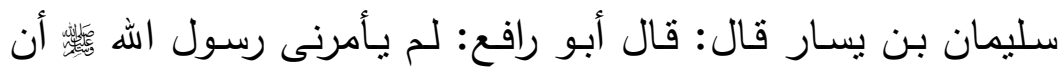

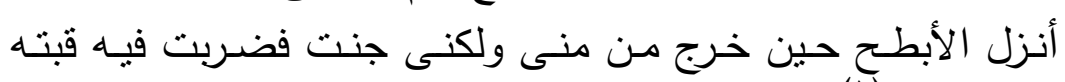

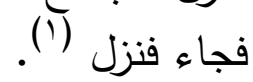

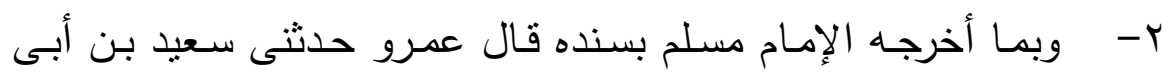

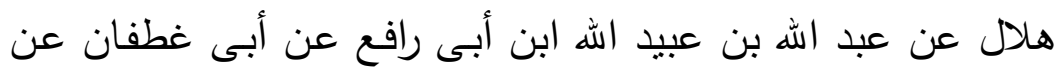

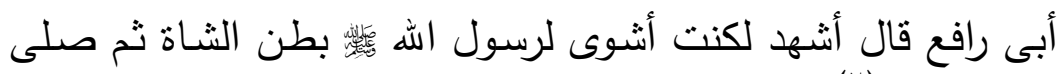

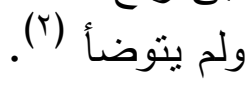

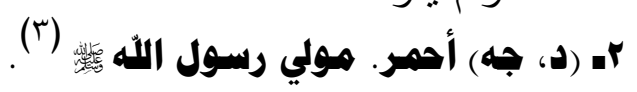

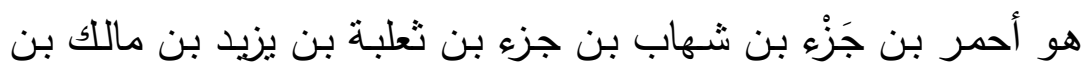

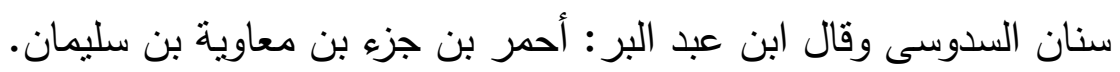

(1) أخرجه مسلم فى كتاب الحج باب استحباب النزول بالمحصب يوم النضر والصلاة بـه

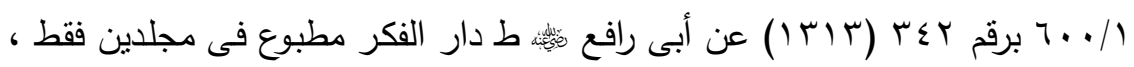

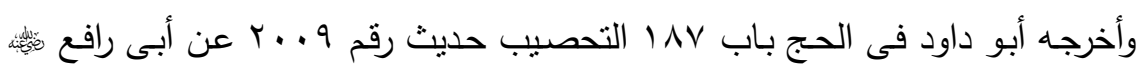
منله.

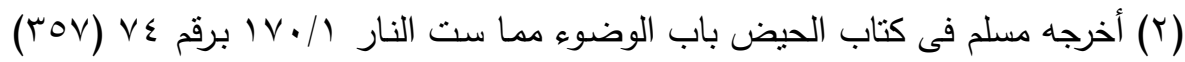

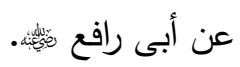

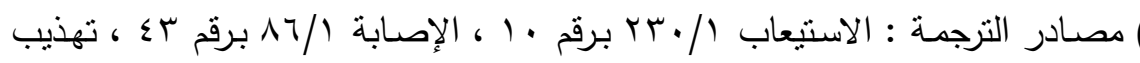

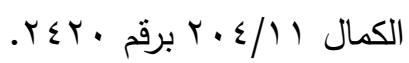




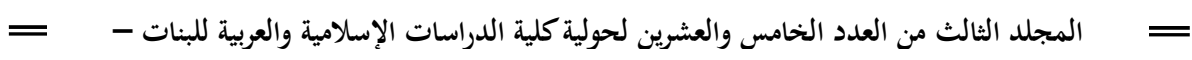

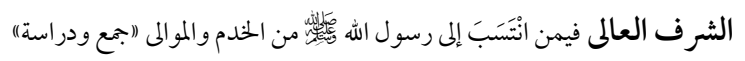

يكنى: أبا جزء له صحبه، وروى عنه الحسن البصرى ولم يرو عنه غيره

فيما علمت.

وقال عباد بن راثد عن الحسن البصرى: حدثنى أحمر مولى رسول الله

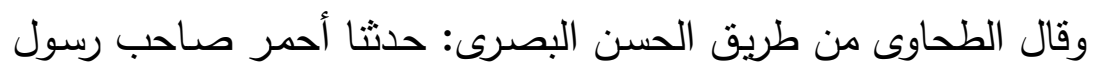

الله

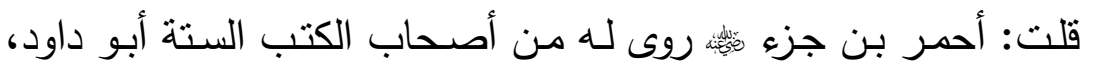

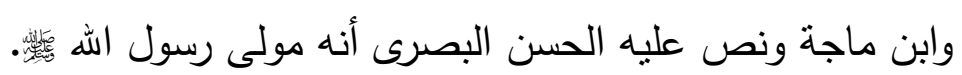

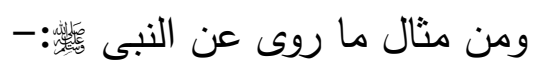

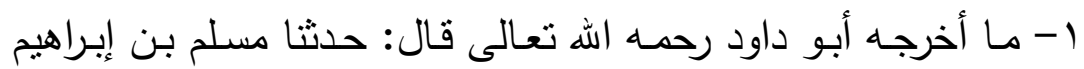

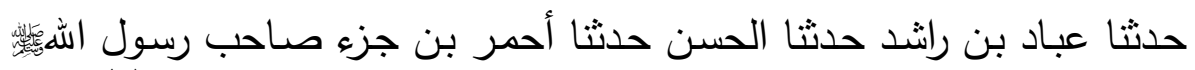

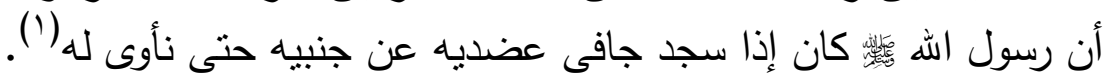

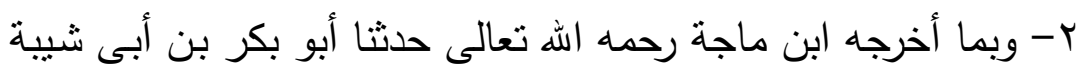

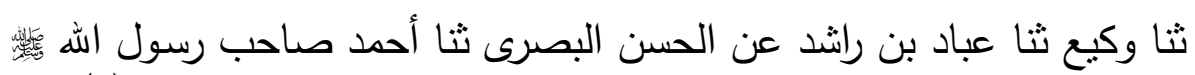

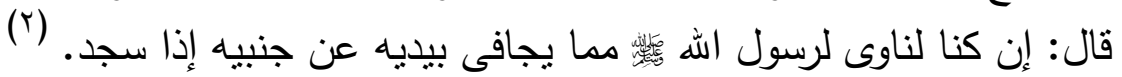

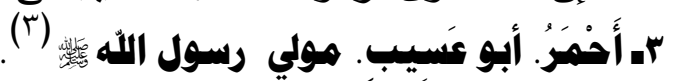

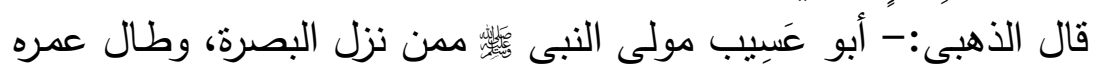

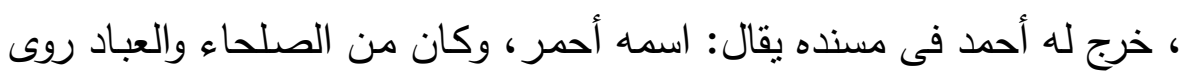

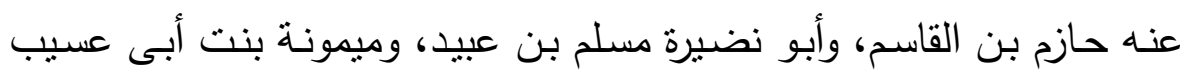

(1) أخرجه أبو داود فى كتاب الصلاة باب صفة السجود 1/1 / 000 حديث رقم . .9.

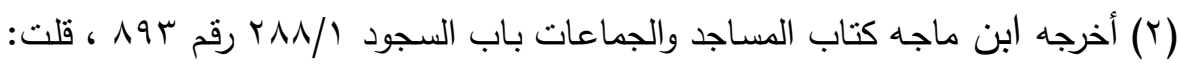

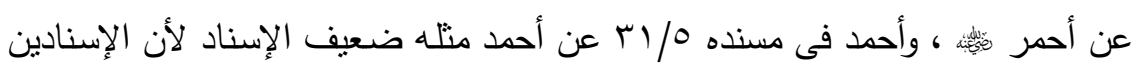

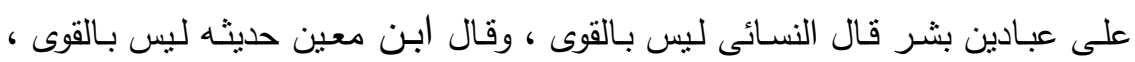

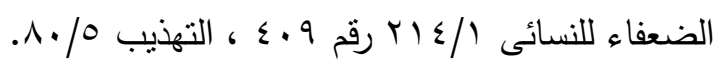

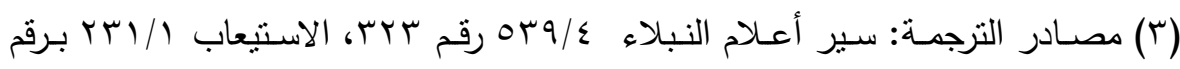
l///

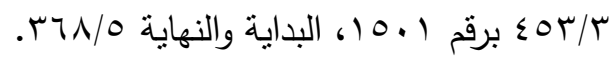
ar 


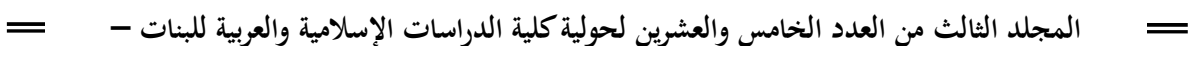

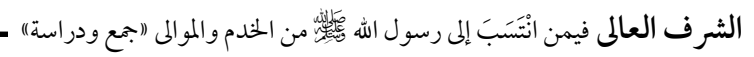

وقالت: كان أبى بواصل بين ثلاث فى الصيام، وبصلى الضحى قائما فعجز

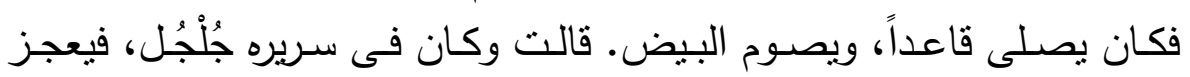
صوته حتى يناديها به فإذا حركه جاءت وند

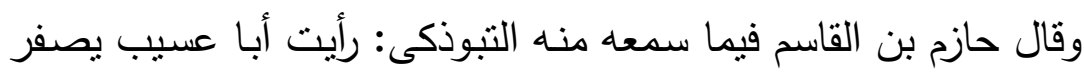

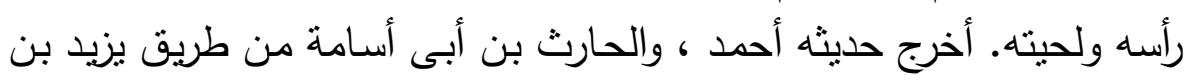

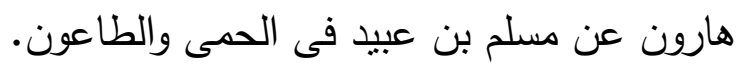
وقال ابن حجر : مشهور بكنيته.

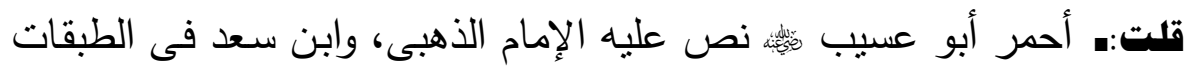

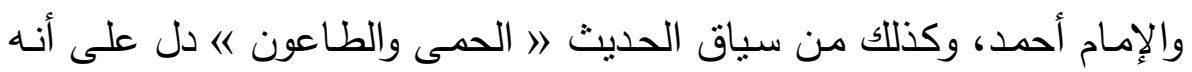
• مولى رسول الله

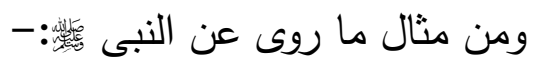

قال الإمام أحمد رحمه الله تعالى:- ثنا بزيد مسلم بن عبيد البيد أبو نصبرة

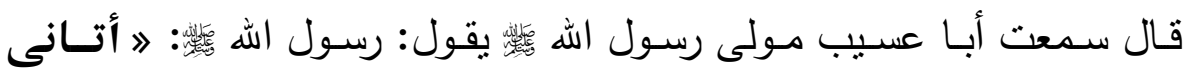

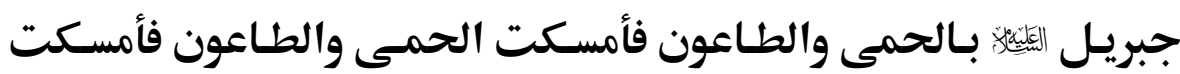

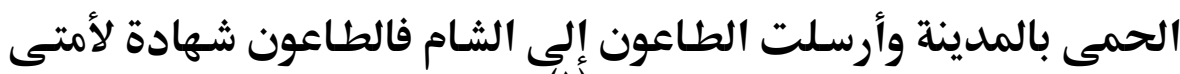

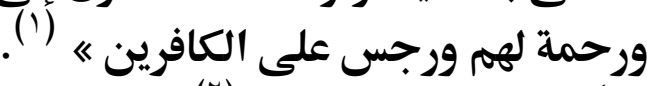

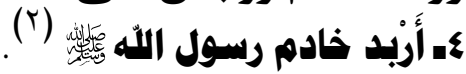
ذكره ابن مندة فى تاريخه من طريق أصبخ بن زيد عن سعيد بن راثند

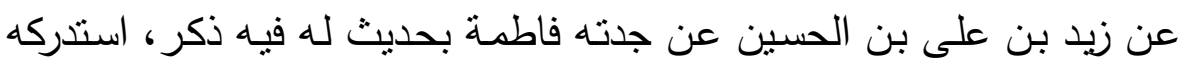
أبو موسى نع

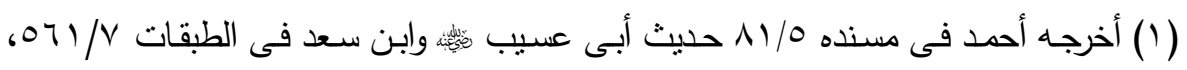

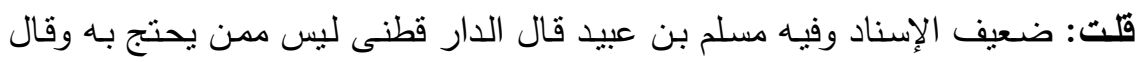

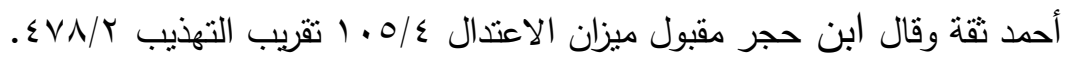

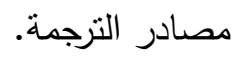
الإصابة / / ـ 1 برقم V، أسير الغابة // آس، ولم أقف على تخريج حديثه. 


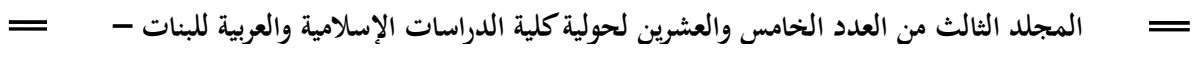

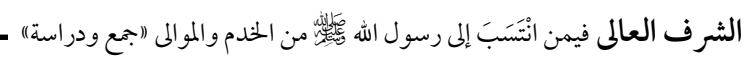

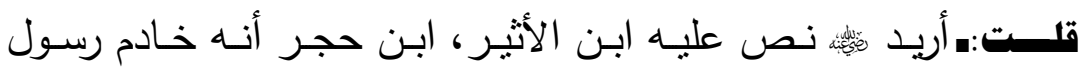

الله

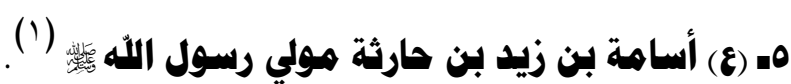

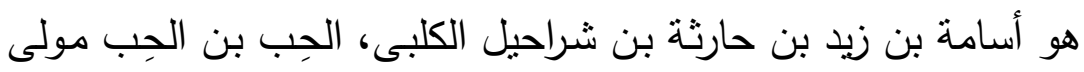

رسول الله

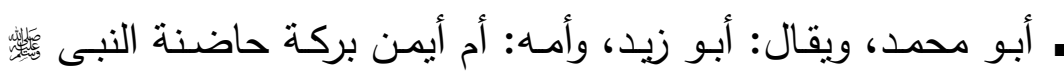

ومولاته.

روى عن النبى

وعنه: أبو هريرة، وابن عباس، ومن كبار التابعين أبو عثمان النهدى ابهى وعن النه

وآخرون.

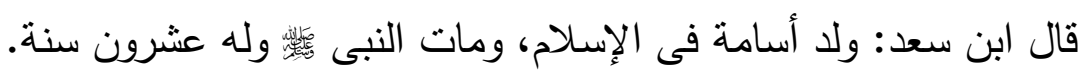

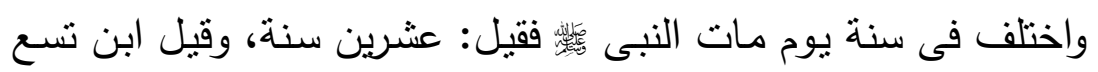

عشرة، وقيل: ابن ثمان عشرة.

وكان النبى

فأنفذه أبو بكر ، وكان عمر يجله ويكرمه، وفضله فى العطاء على ولده عبدالله

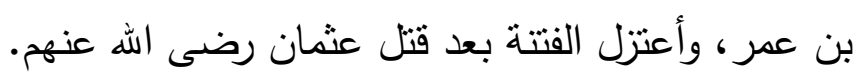
وكان قد سكن المزه من عمل دمشق ثم رجع فسكن وادى القرى، ثم نزل إلى المدينة فمات بالجرف فى آخر خلافة معاوية.

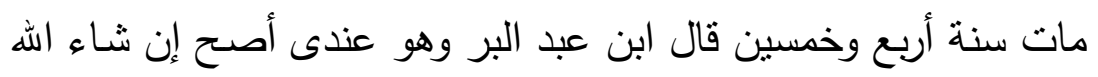

تعالى.

مصادر الترجمة:-

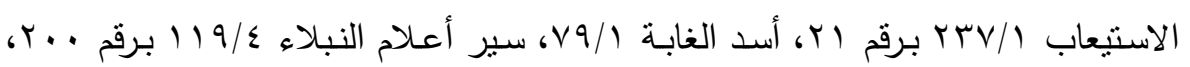

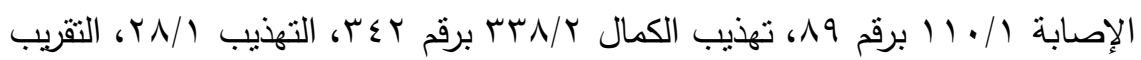
1/1/ 


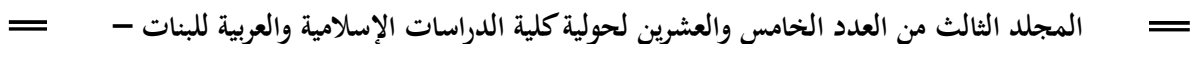

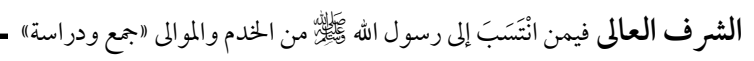

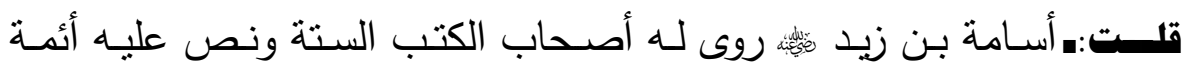

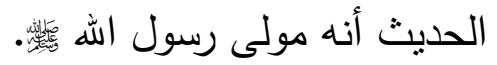
ومن مثال ما روى عن النبى مولى رسول

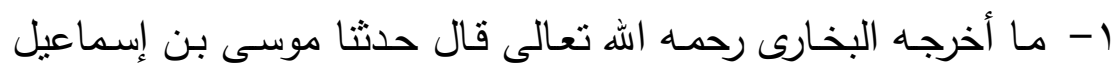

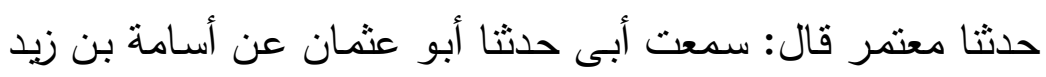

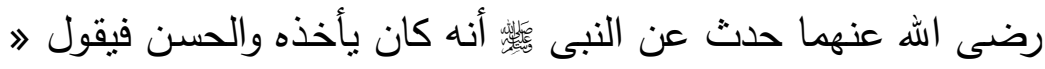
اللهم أحبهما فإنى أحبهما « (1).

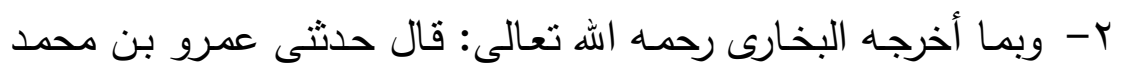

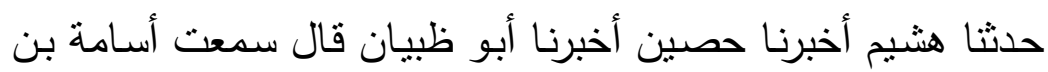

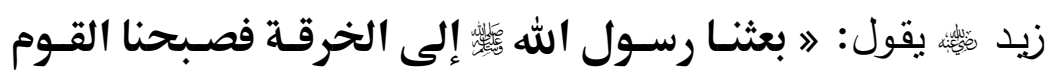

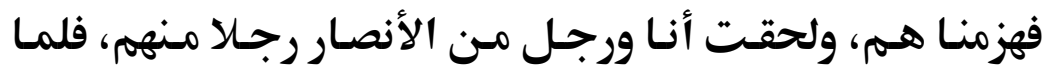

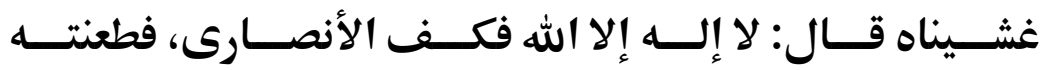

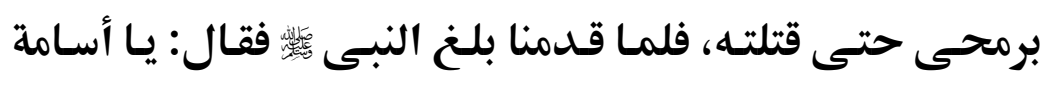

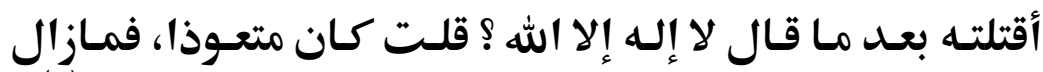

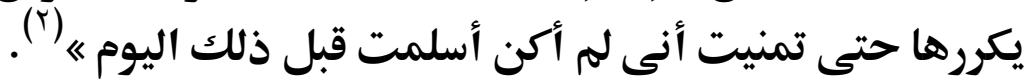

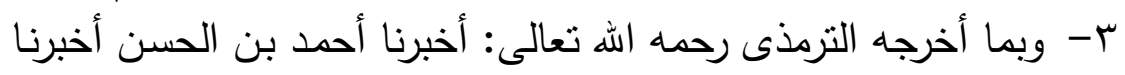

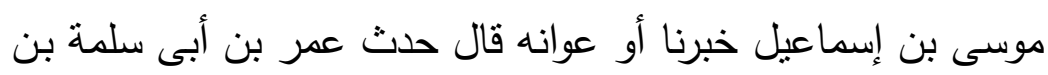

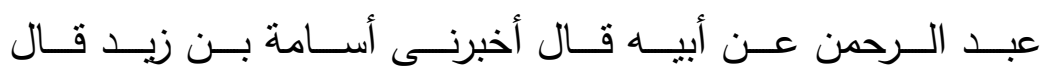

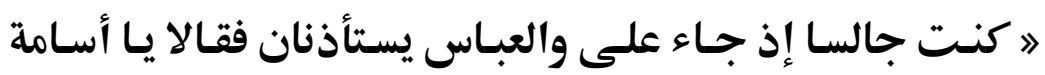

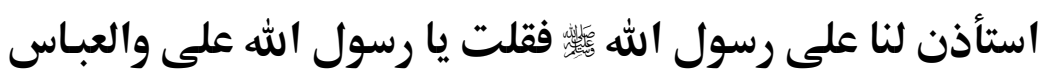

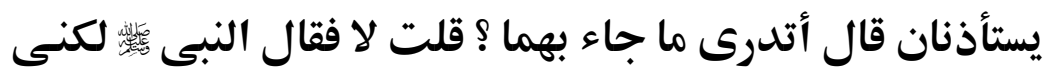

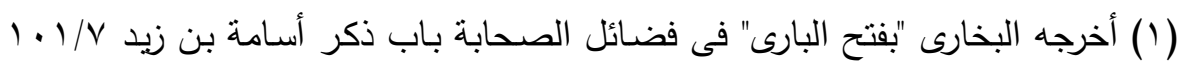
رقم סTVז.

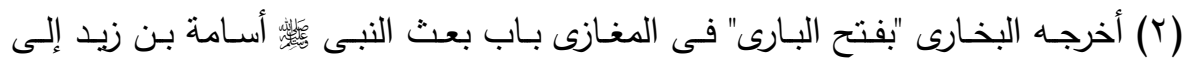

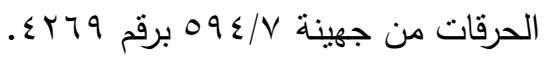




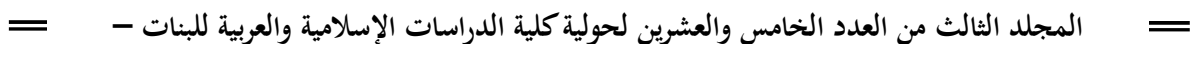

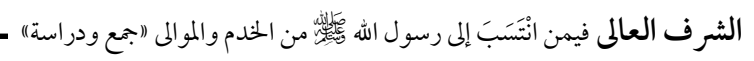

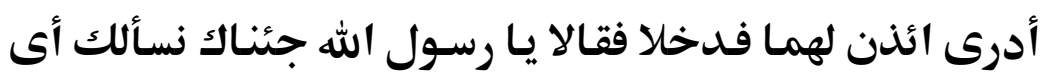

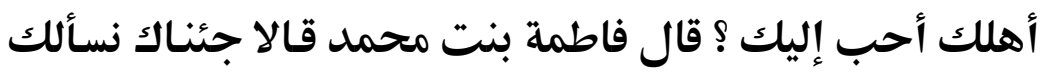

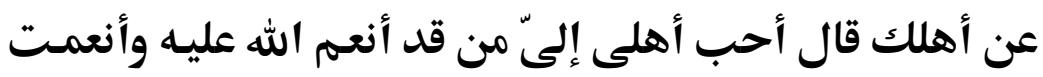

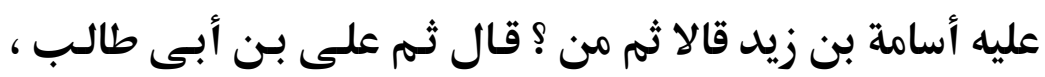

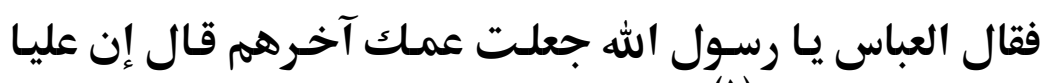

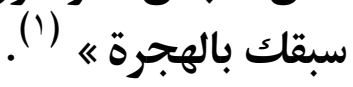

14. أسد. هولي رسول الله (ז).

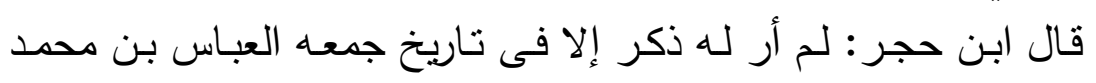

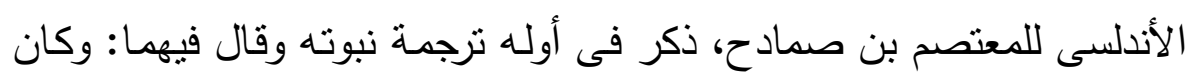
أنس ابن مالك ومولاه أسد بستأذنان عليه.

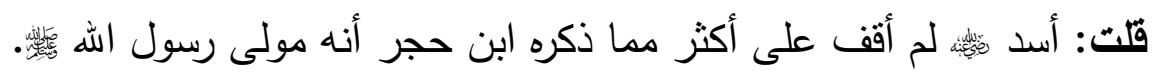

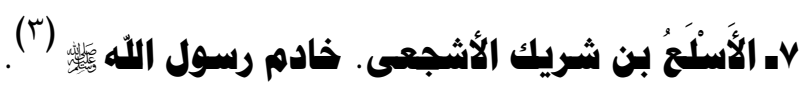

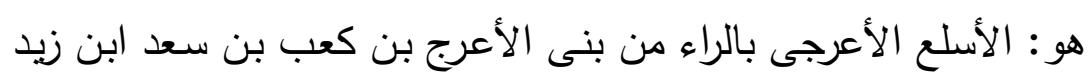

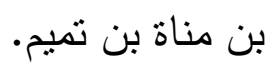

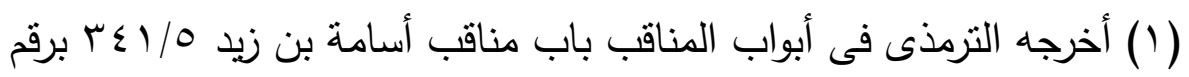

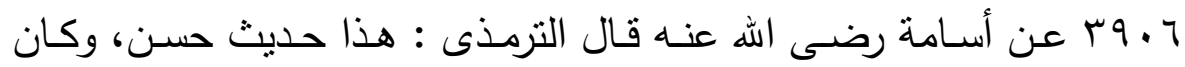
شعبة يضعف عمر بن أبى سلمة.

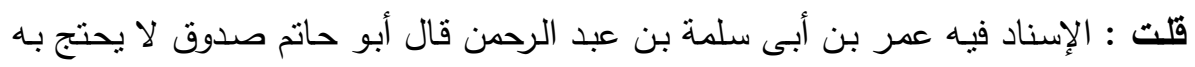

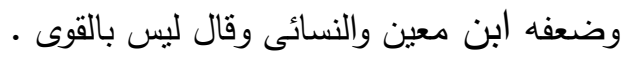

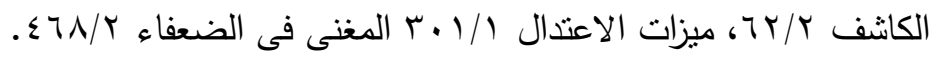

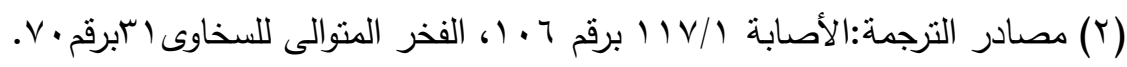

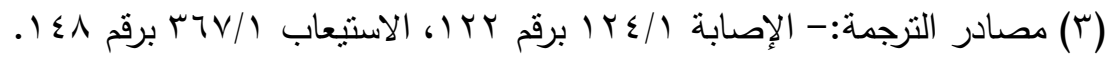
ar 


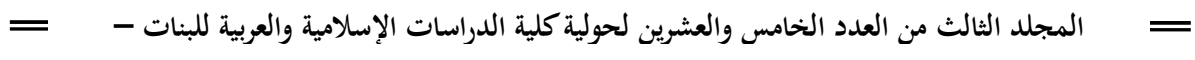

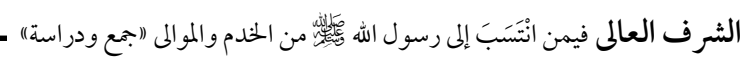

وقال الطبرانى فى الترجمة الأسلع بن شريك الأثجعى ثم ساق حديثه

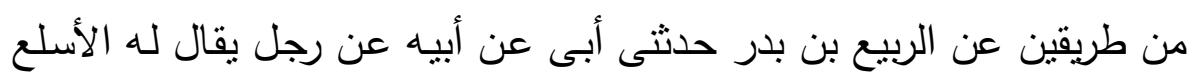

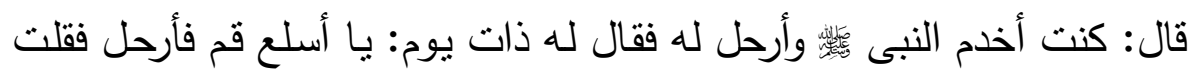
يا رسول الله أصسابتتى جنابـة فسكت رسول اله لها

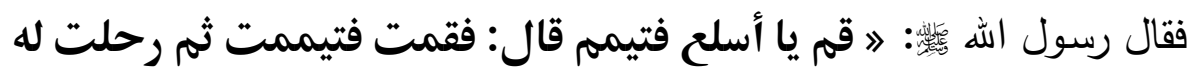

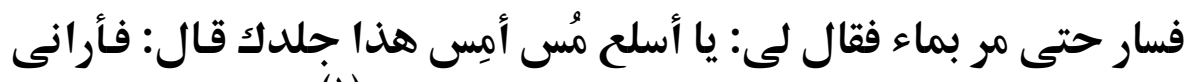

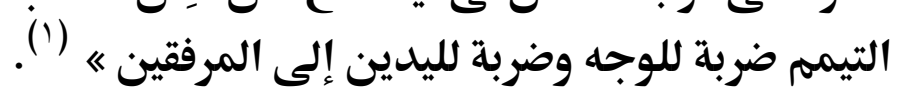

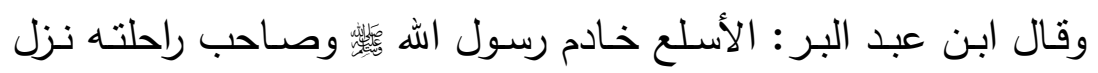
البصرة، وروى عنه زريق المالكى. وقال خليفة فى تاريخه: ومن بنى العرج بن كعب الأسلع بن شريك روى رئ عن النبى

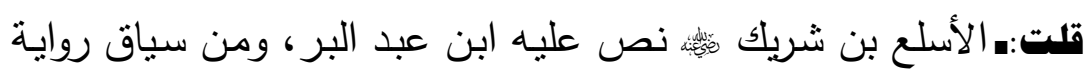

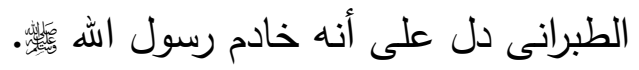

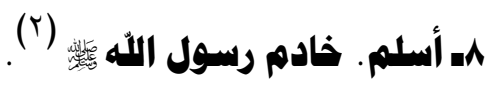
قـال ابـن منـده: روى إسـحاق بـن سـليمان عن سـعيد بـن عبد الرحمن

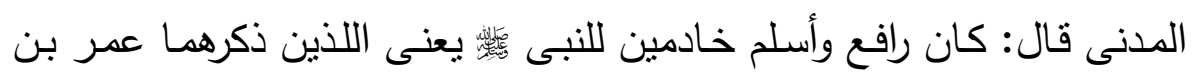

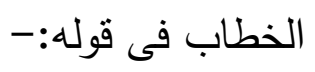

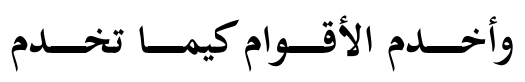

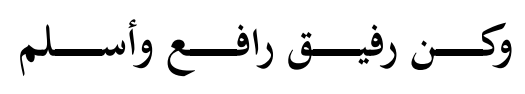

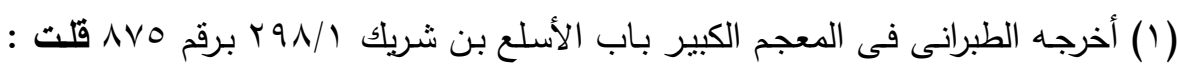

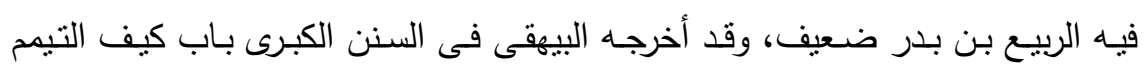

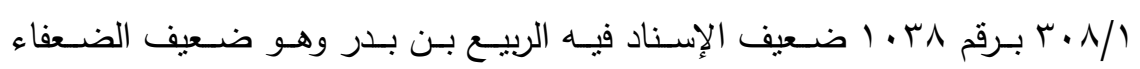

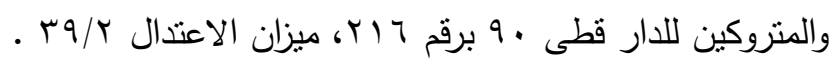

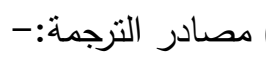

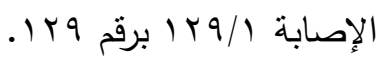




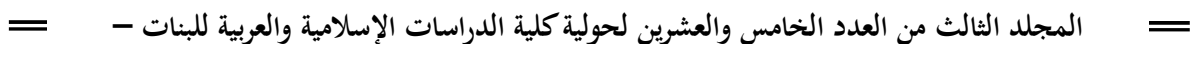

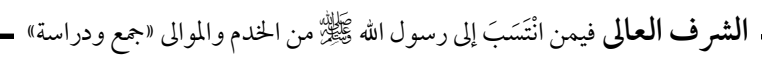

وهو خبر رواه ابن وهب عن عبد الرحمن بن زيد بن أسلم عن أبيه عن

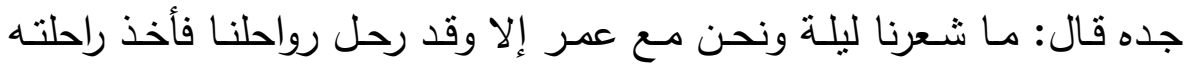

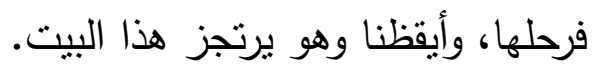

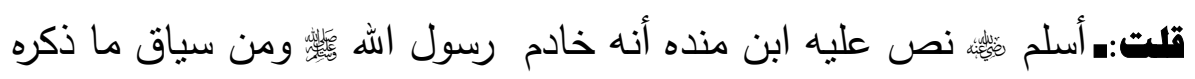

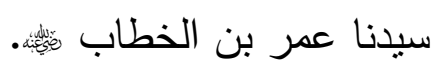

\section{9ـ أسلم بن عبيدة. هولي راسول اللهـ (1)}

هو أبو خالد، وقيل: أبو زيد العدوى، وقال وابول ابن سعد: حبشى بيحاوى. قال ابن حجر : ذكره الدمياطى فى موالى رسول الله فئس

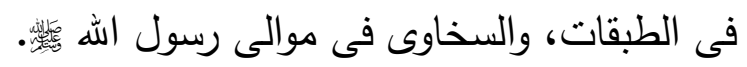

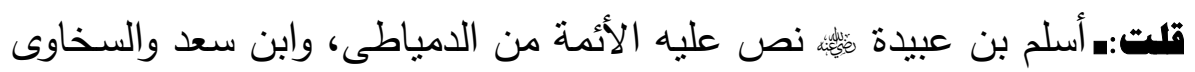
، وابن الأثير أنه مولى رسول اله بله

\section{• اـ أفلح. هولي ريسول الالهه (r).} قال أبو عمر : مذكور في مواليه. قال ابن منده: روى حديثه يوسف بن خالد عن مسلم بن بشير أنه سمع

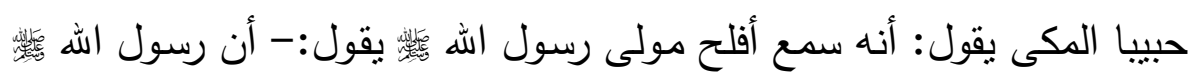

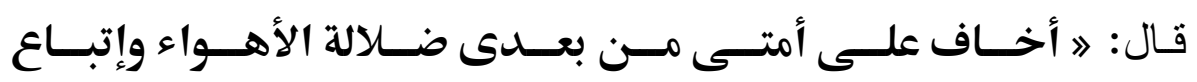
الشهوات « قال ونسبت الثالثة. انتهى رواه الحكيم الترمذى فى نوادره من هذا

(1) مصادر الترجمة:-

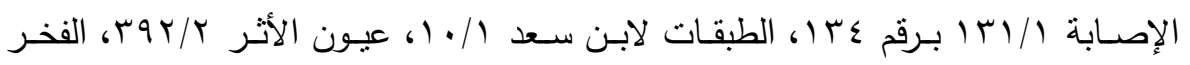

$$
\text { المنوالى الس برقم } 9 .
$$

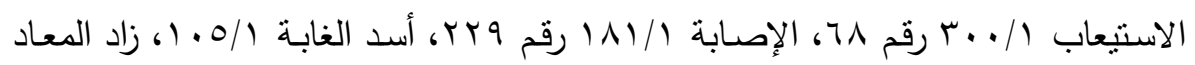




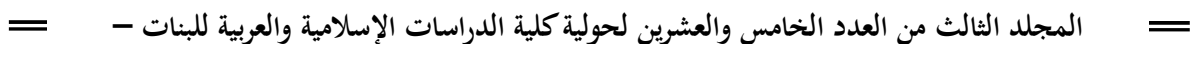

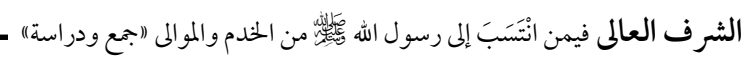

الوجه وسمى الثالثة: العُجْبَ (1) • ورواه ابن شـاهين، فسمى الثالثة (الغفلة بعد

المعرفة) - موجه

ومداره على يوسف بن خالا وهو السمتى: متروك الحديث.

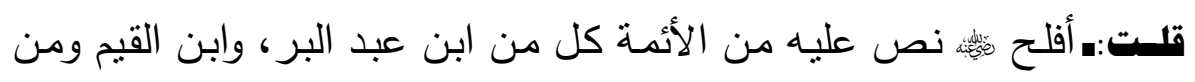

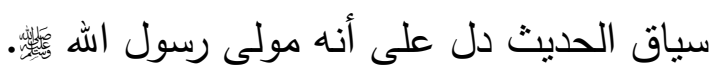

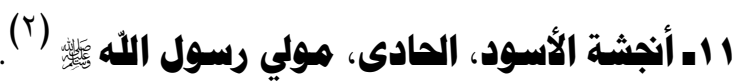

كنيته:ـ أبو مارية، وكان حسن الصوت، الحداء، وقال البلاذرى: كان حبثيا.

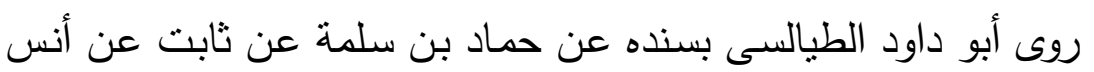

قال: كان أنجشة يحدو النساء، وكان البراء بن مالك، يحدو الرجال فإذا أعتقب

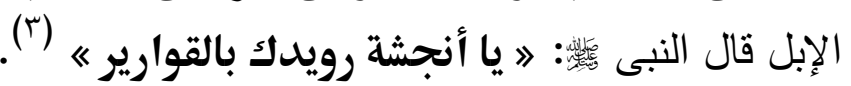

وقال أبو عمر : أنجشة العبد الأسود كان يسوق أو يقود بنا النبى لئس حجة الواداع، وكان حسن الحداء، وكانت الإبل تزيد فى الحركة بحدائه فقال

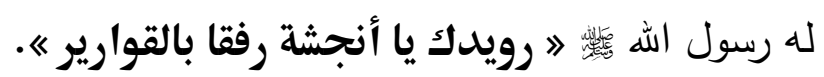

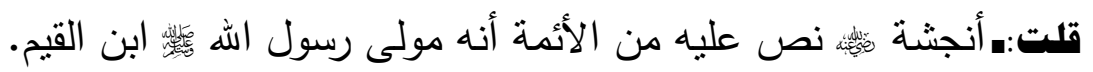

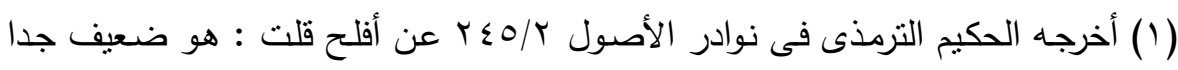
لأن فيه يوسف بن خالد متروك الحديث.

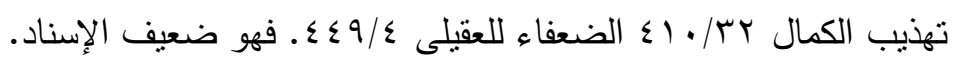

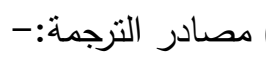

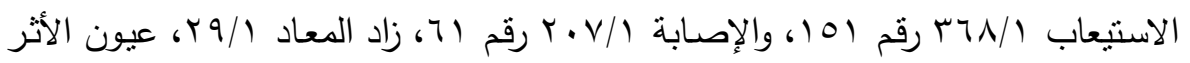
$. r q \mu / r$

(r) أخرجه البخارى "بفتح البارى" فى كتاب الأدب باب ما يجوز من الشعر والرجز والحداء

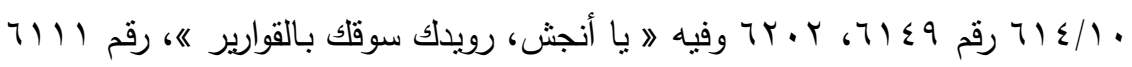
وفيه " لا تكسر القوارير "، ومسلم فى الفضائل رقم • V، VY، والدار فى الاستئذان 70، وأحمد 


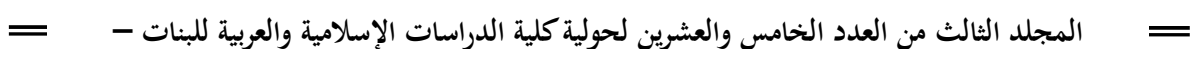

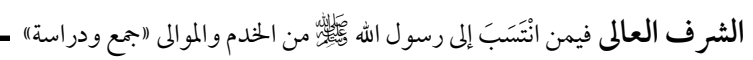

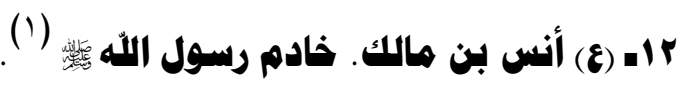

هو أنس بن مالك بن النضر الخزرجى النهى، أمه أم سليم، وكنيته: أبو حمزة

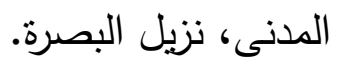

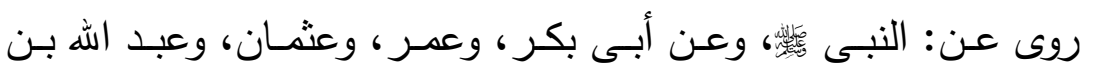
رواحة وفاطمة الزهراء، وأمه أم سليم وآخرون.

وعنه: الحسن وسليمان التيمى، وعن العزيز بن صهيب وآئه وطائفة.

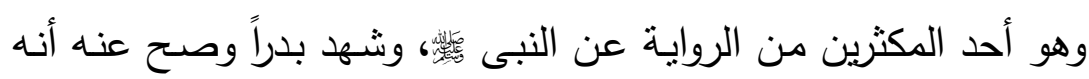

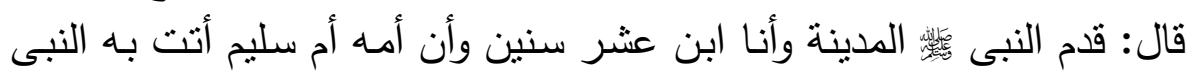
.

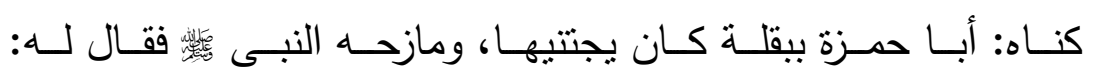

يا ذا الأذنين (ن)

قال أنس: قالت أم سُّليم: يارسول اله ادع اله لأنس فقال: ه اللهم أكثر

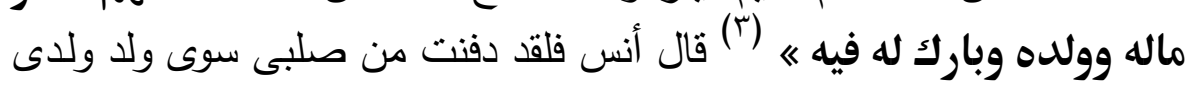

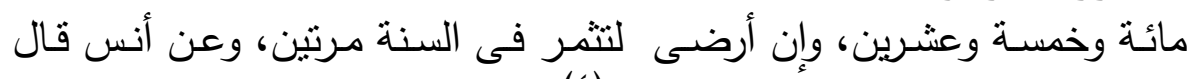
كنائى النبى وخى

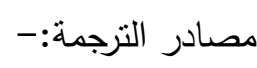

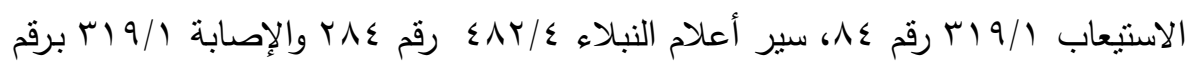

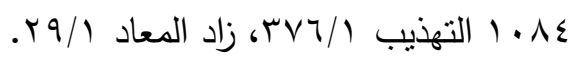

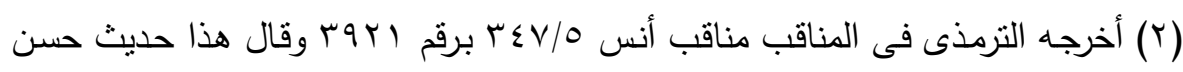

$$
\text { غريب صحيح. }
$$

(ז) أخرجه البخارى "بقتح البارى" فى كتاب الدعوات باب الدعاء بكثرة المال والدفع البركة

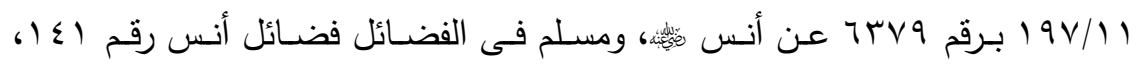

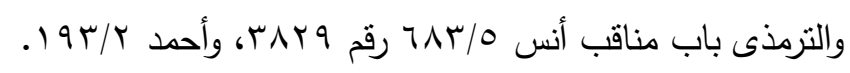

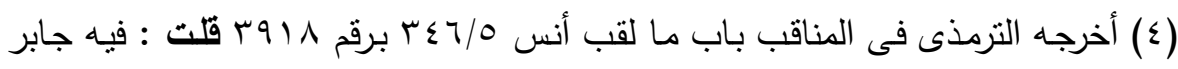

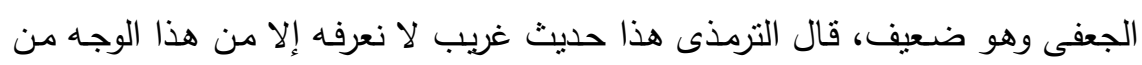

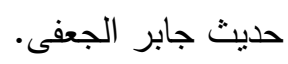




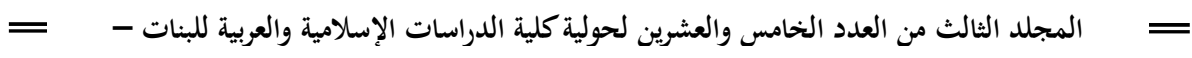

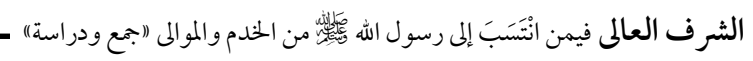

مات ثمئئة سنة اثتنين، وقيل ثلاث وتسعين، وقد جاوز المائة.

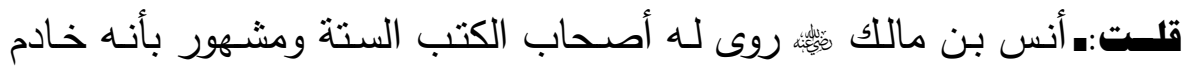
النبى ومن مثال ما روى عن النبى

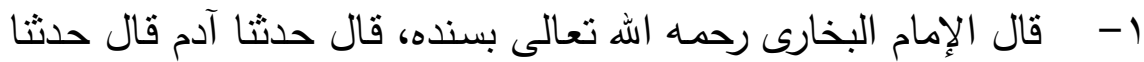

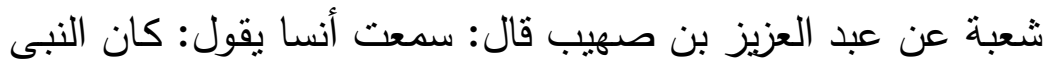

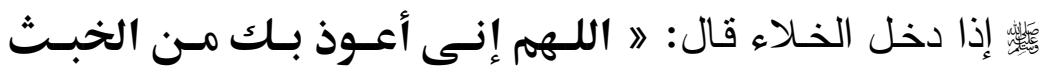
والخبائث 《 تابعه ابن عرعرة عن شعبة، وقال غندر عن شعبة: إذا إداء

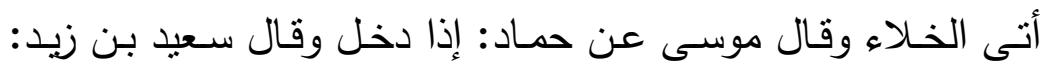

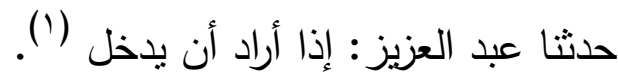

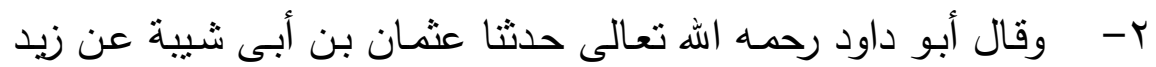

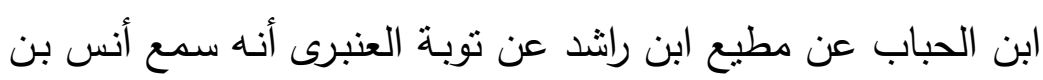

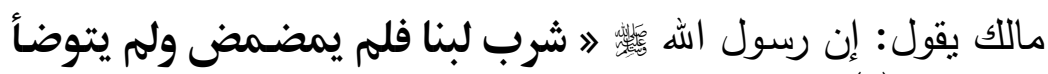
وصلى 《 (r) قال زبد: دلنى شعبة على هذا الثيخ.

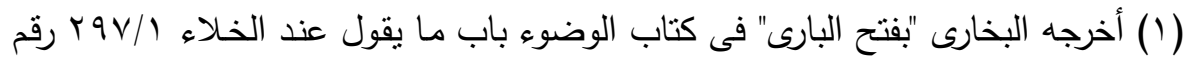

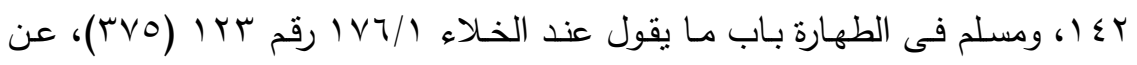

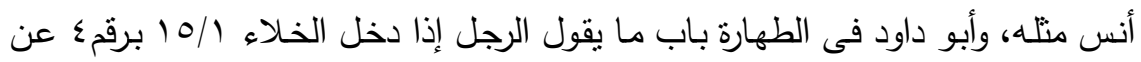

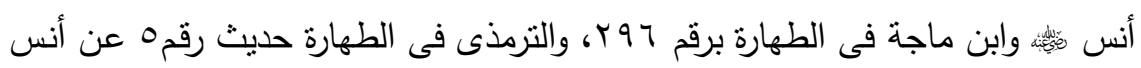

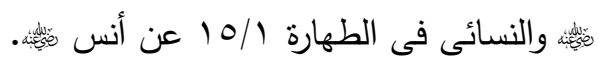

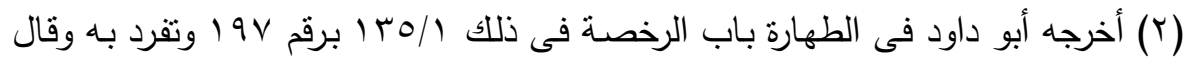

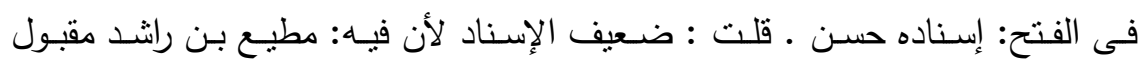

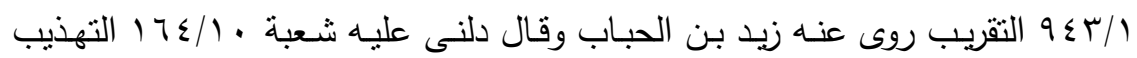
 


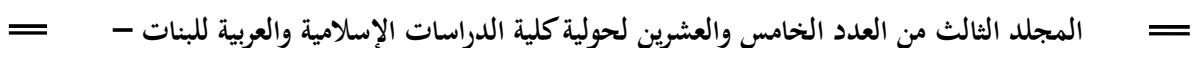

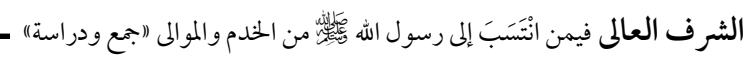

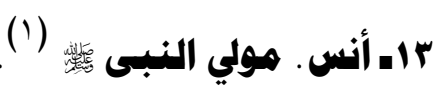

قال الواقدى: عن ابن أبى الزناد عن محمد بن يوسف فال: مات أنس أنس

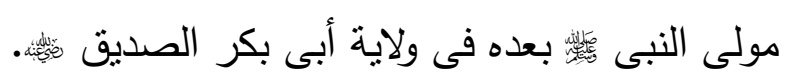

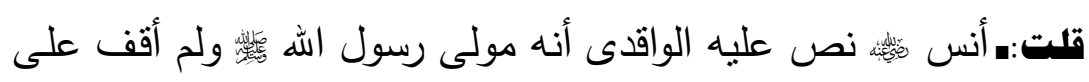

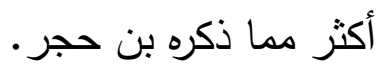

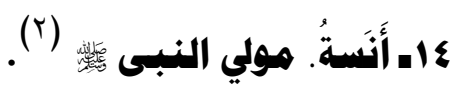

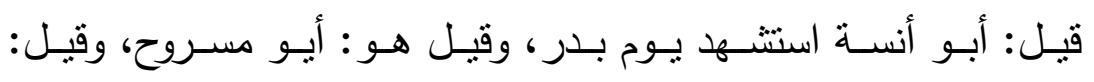

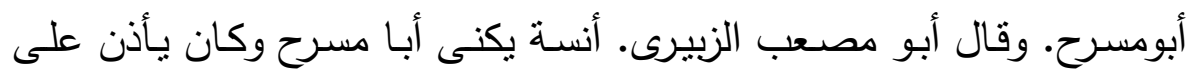

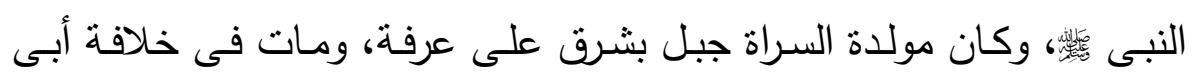
بكر .

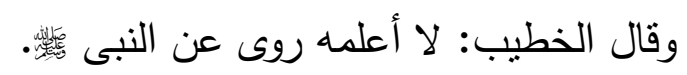

ذكره موسى بن عقبة عن ابن شهاب فيمن شهر بدراً واستنشه بها.

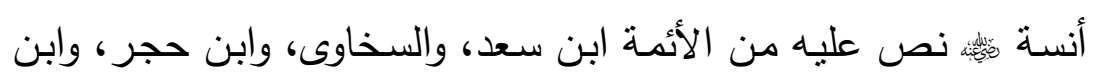

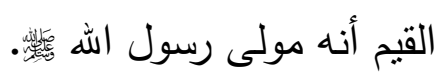

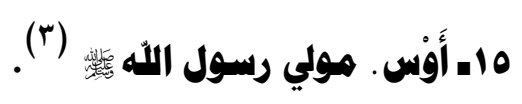

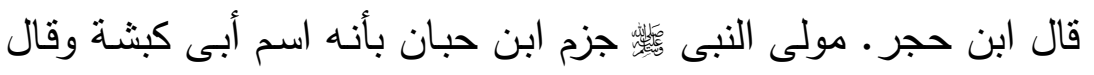

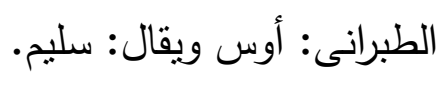

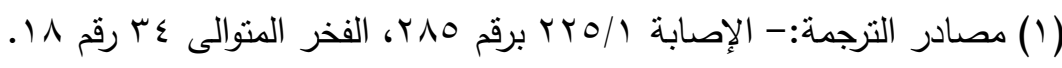

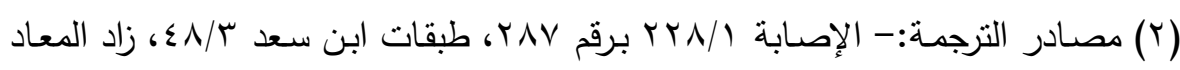

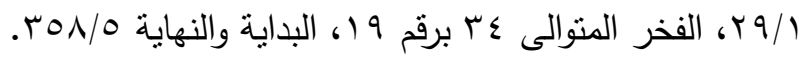

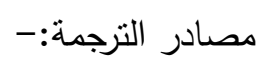

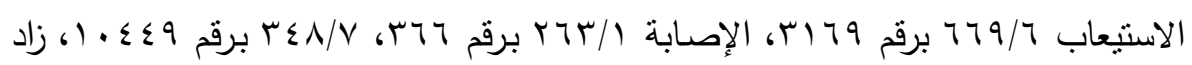

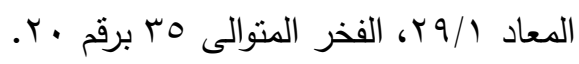

$\overline{=} 1 \cdot r$ 


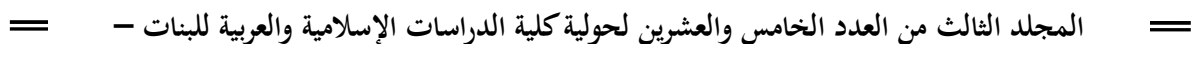

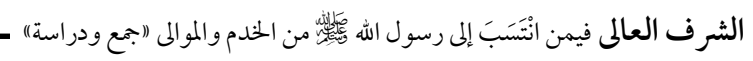

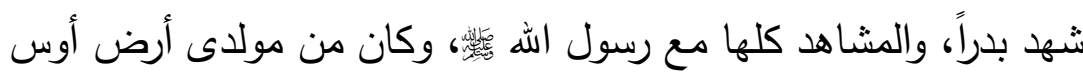

توفى سنة ثناث عشرة فى اليوم الذى استخلف فيه عمر ابن الخطاب.

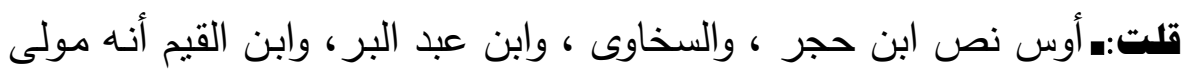
رسول الله

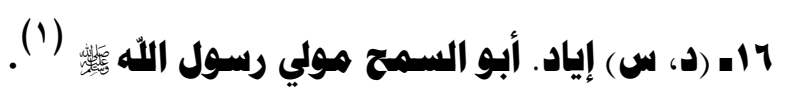

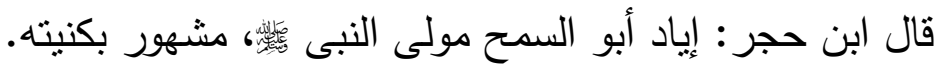

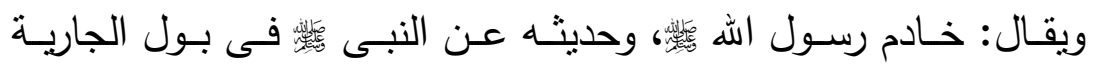

والغلام.

قال ابن عبد البر ويقال: إنه ضل ولا يدرى أين مات.

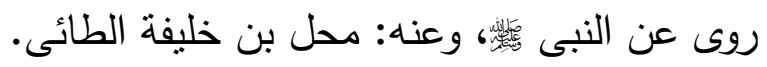
قال أبو زرعة: لا أعرف اسمه ولا أعرف له رواية غير حديث واحد. قلت:ـإياد أبو السمح روى له من أصحاب الكتب الستة، أبو داود، والنسائى، وابن ماجة ونص عليه ابن حجر أنه مولى رسول الهه اله

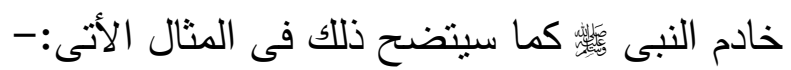

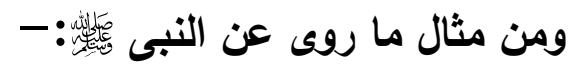

ا - قال أبو داود رحمه الله تعالى: حدثنا مجاهد بن موسى وعباس بن

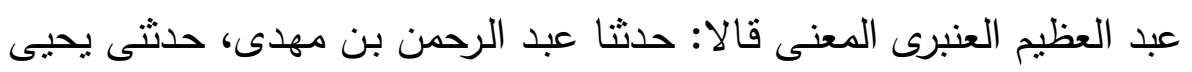

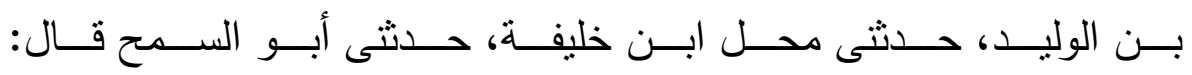

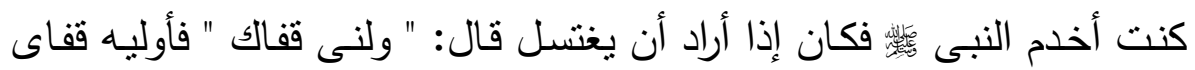

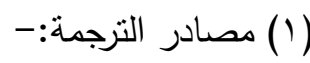

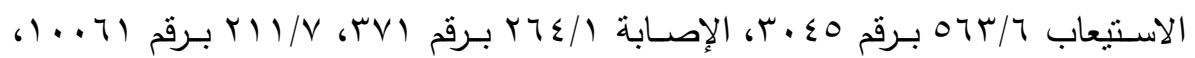

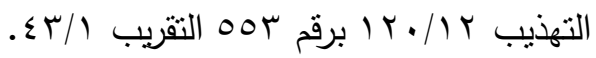
$1 \cdot \varepsilon$ 省 


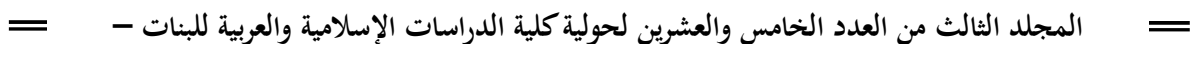

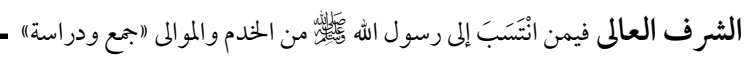

فأستره بـه فأتى بِحَسـن أو حُسـين رضـى الله عنهمـا فبـال على صـدره فجئت

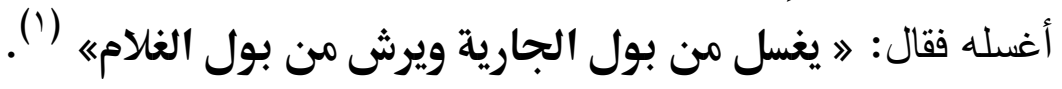

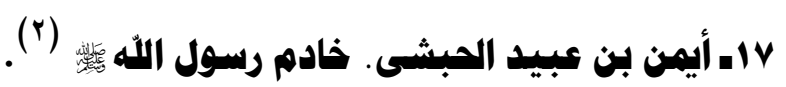

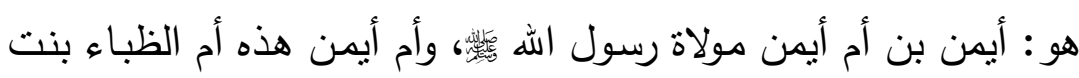

ثعلبة ابن عمرو بن حصن بن ماللك، وهى أم أسامة بن زيد بن حارثة.

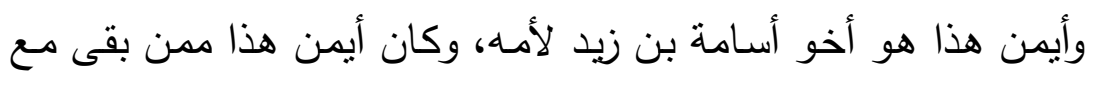
رسول الله قال ابن القيم: كان على مطهرته وحاجته.

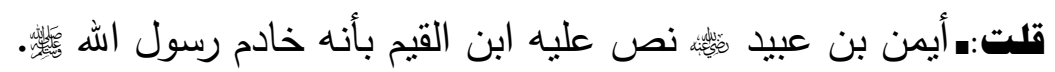

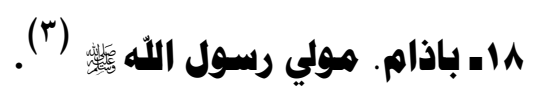

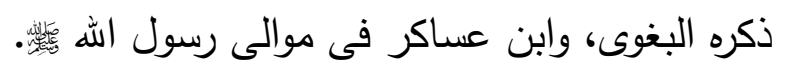

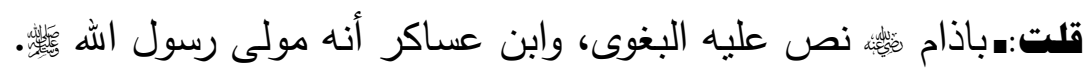

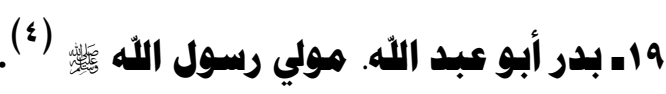
روى محمد بن جابر بن عبد الله عن أبيه حديثا يتحرز فى التجريد.

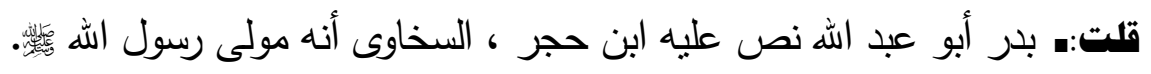

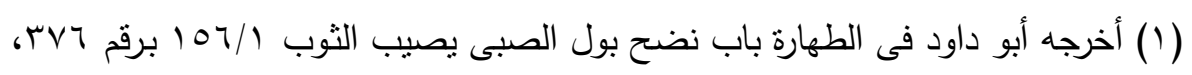

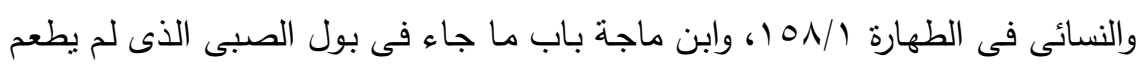

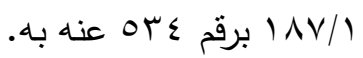

$$
\begin{aligned}
& \text { مصادر الترجمة:- }
\end{aligned}
$$

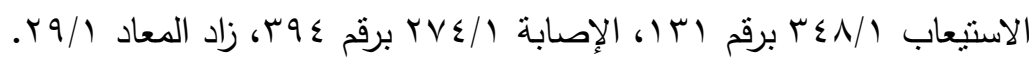

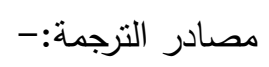

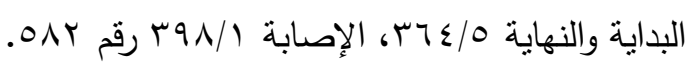

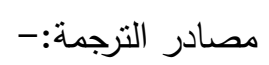

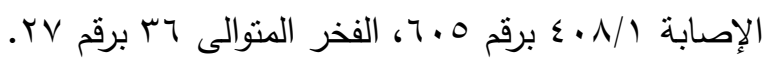




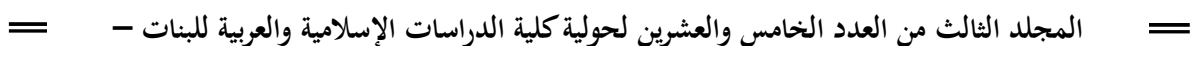

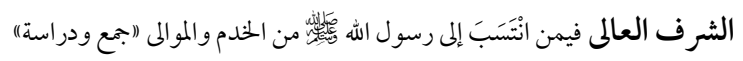

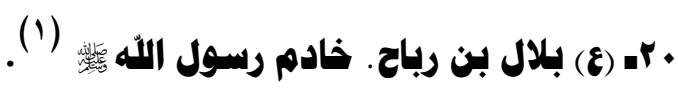
هو : بلال بن رباح التيمى، مولالهم، المؤذن، أبو عبد الله، ويقال: أبوعبد الرحمن وقيل غير ذللك.

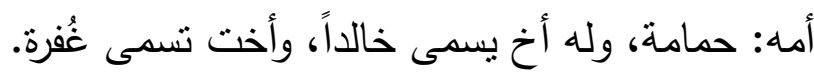

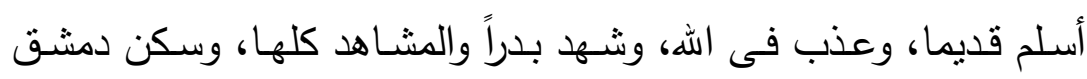
وهو مولى أبى بكر ثم أعنقه، وكان له خازنا، ولرسول الله مؤذنا.

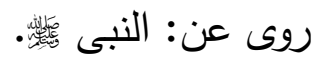
وعنه: أبو بكر ، وعمر ، وأسامة بن زيد، وكعب بن عجرة وغيرهم.

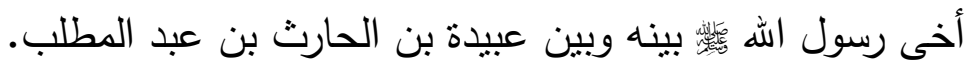
وكان آدم شديد الأدمة، نحيفا، طوالا أجنى خفيف العارضين الحين.

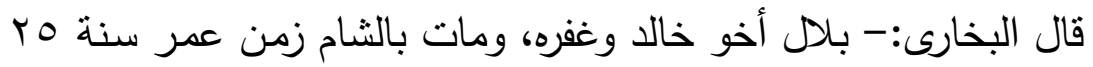

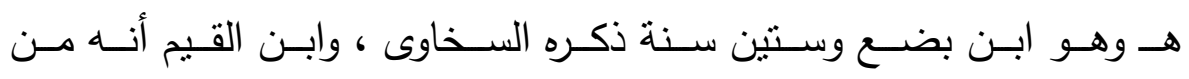
خدمه

قلت:ـبلال بن رباح قائه، روى له أصحاب الكتب الستة ونص عليه من الأئمة

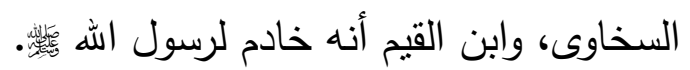

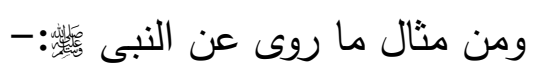

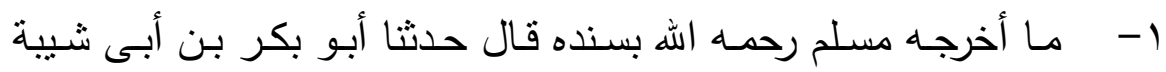

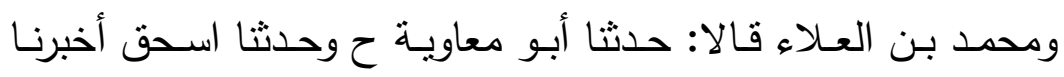

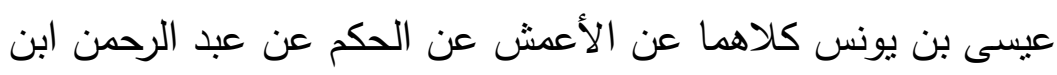

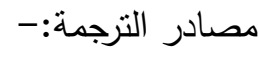

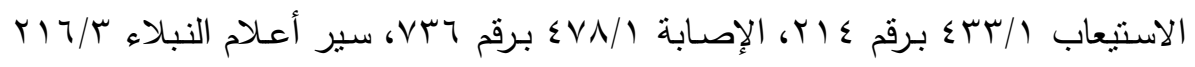

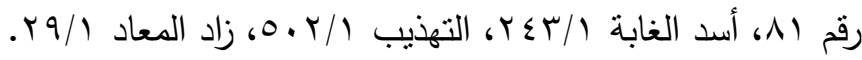




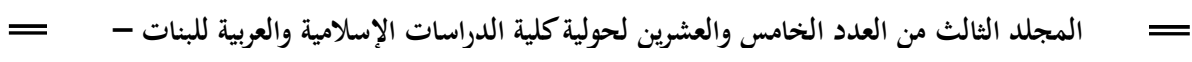

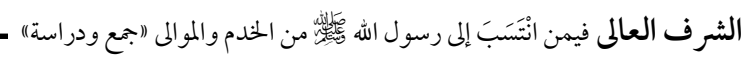

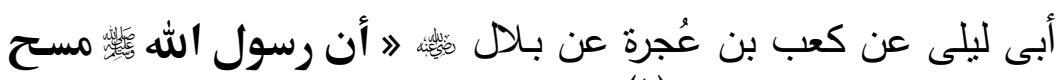
على الخفين والخمار « ( ').

r - وبما أخرجه الترمذى رحمه الله تعالى قال حدثنا أحمد بن منيع حدثنا

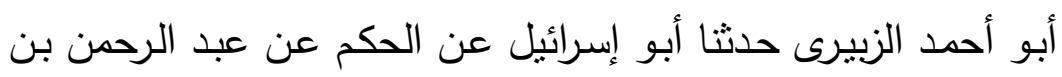

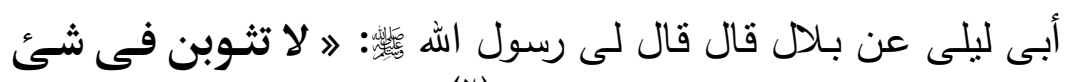

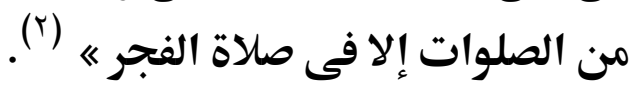

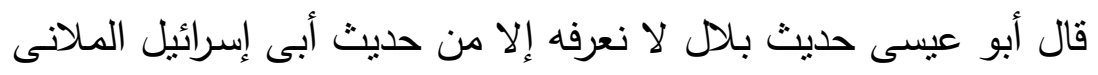

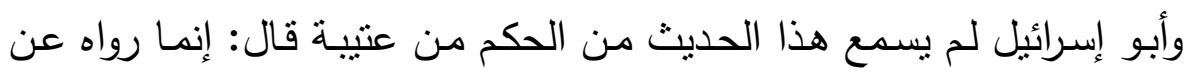

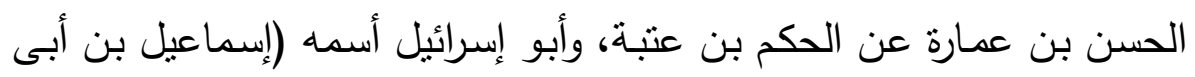
إسحاق) وليس هو بذاك القوى عند أهل الحديث.

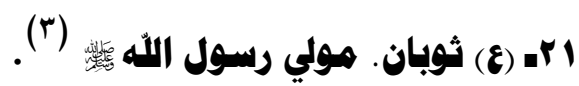
هو : أبو عبد الله، وقيل: أبو عبد الرحمن، وأبو عبد الله أصح.

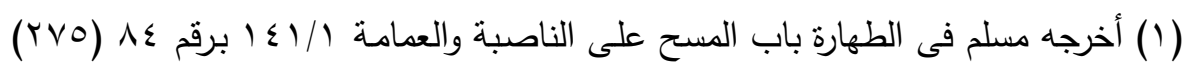

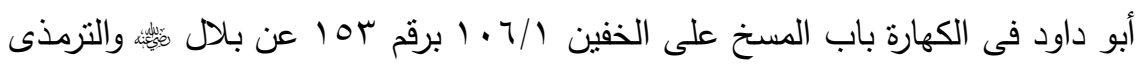

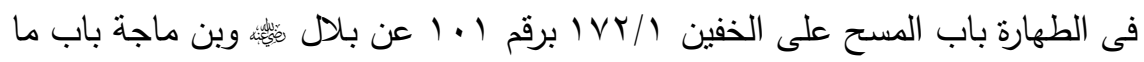

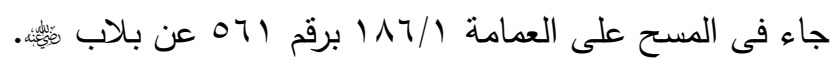

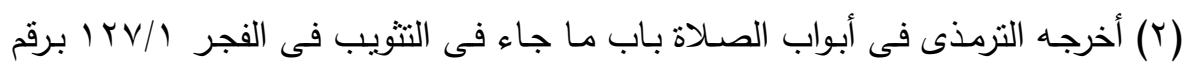

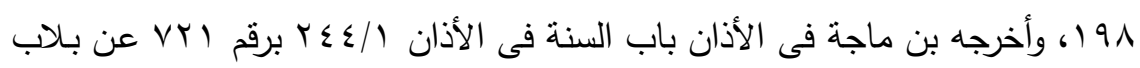

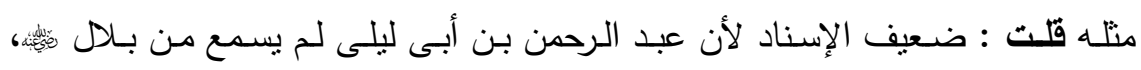

$$
\text { والتتويب " الصلاة خير من النوم ". }
$$

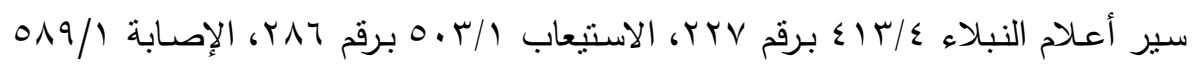

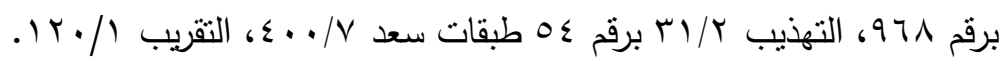




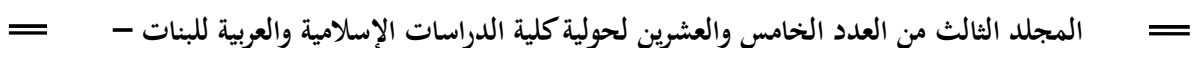

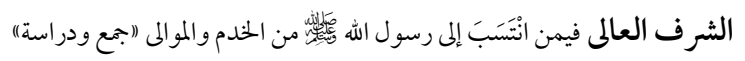

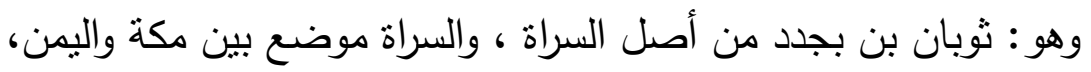

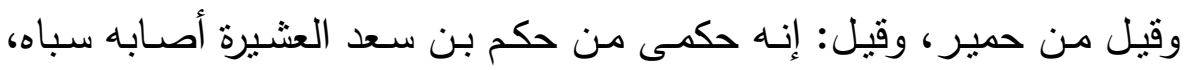

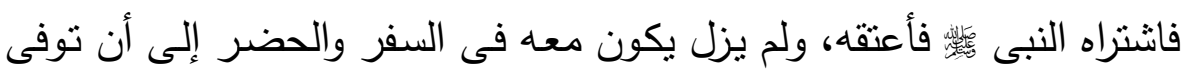

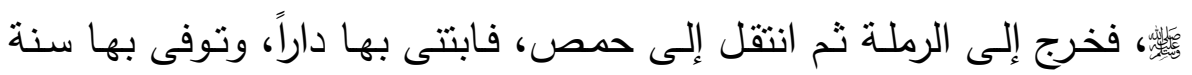

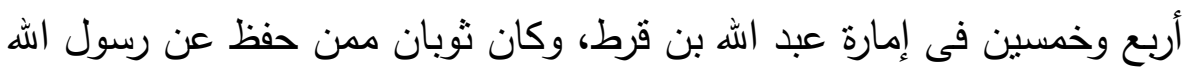
.

روى عنـه جماعـة مـن التابعين: جبير بـن نفير الحضـرمى، وراثـد بن

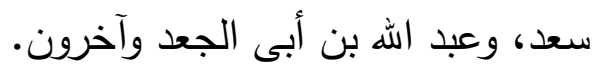
مات بحمص سنة أربع وخمسين.

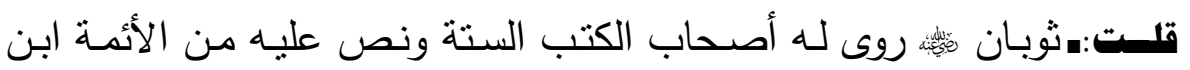

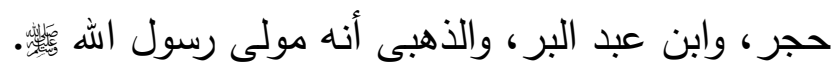

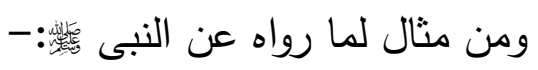

قال الإمـام أبو داود رحمـه الله تعالى :- حدثنا سليمان بن حن حرب حدثنا

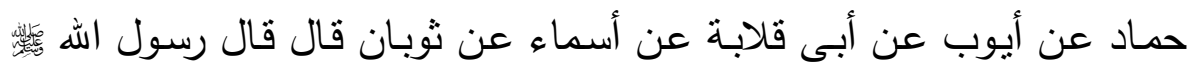

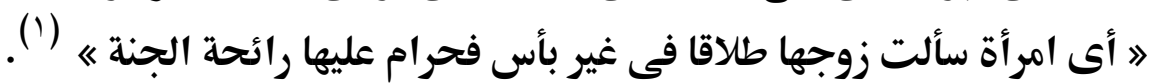

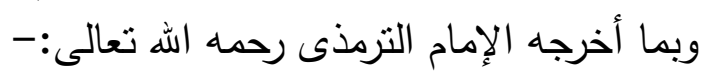

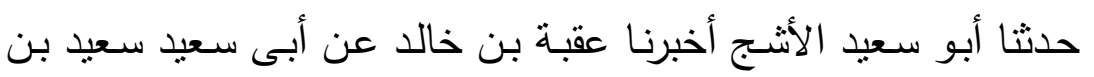

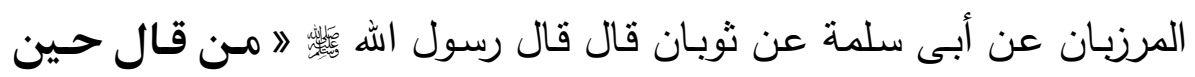
يمسى رضيت باله ربا وبالإسلام دينا وبمحمد نبياً كان حقا عله الهى اله أن أن

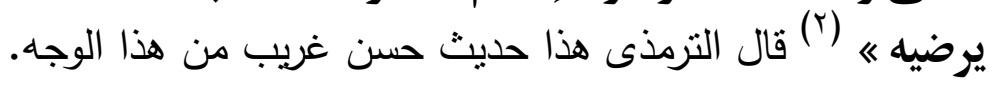

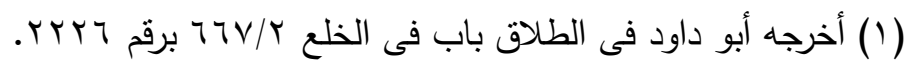

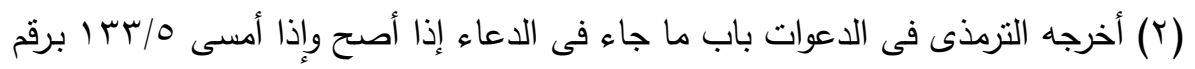

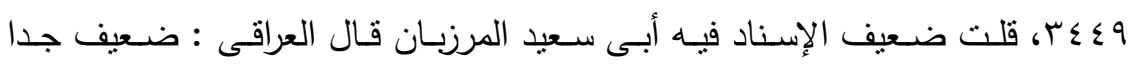

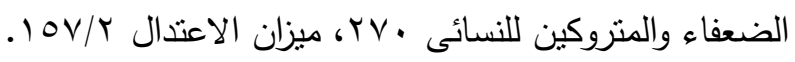




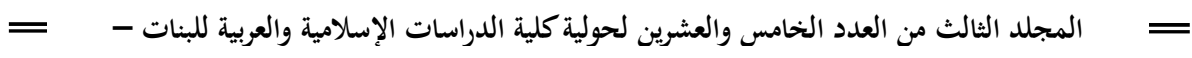

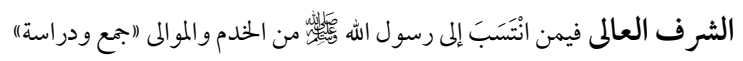

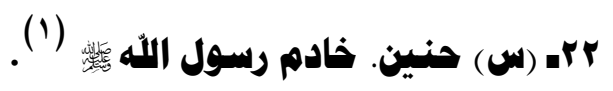

هو والد عبد الله مولى ابن عباس عن على فى النهى عن لباس القسى وغيره.

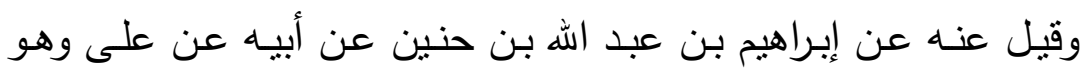

المحفوظ رواه النسائى فى " الإختلاف ".

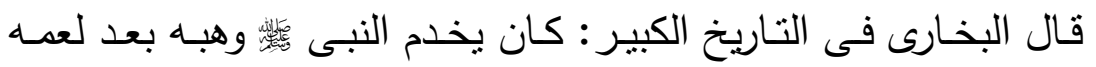

العباس فأعتقه، كذا قال أبو حاتم الرازى.

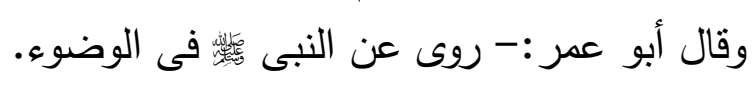

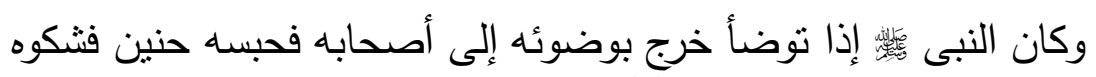

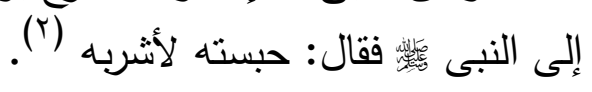

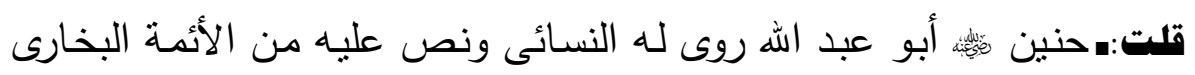
وابن حجر أنه خادم النبى عنى أسئ.

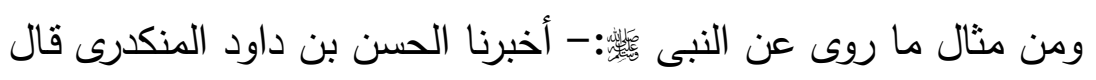

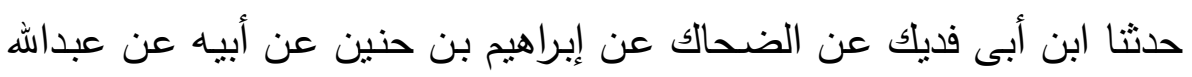

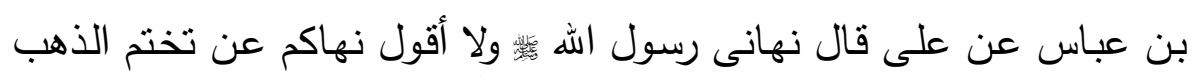

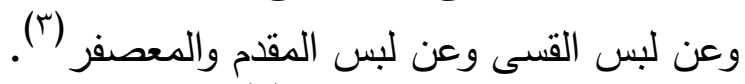

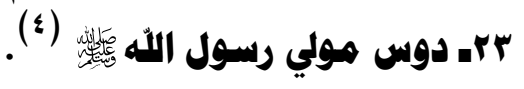
قال ابن منده لـه ذكر فى حديث رواه ماه محمد بن سليمان الحرانى عن

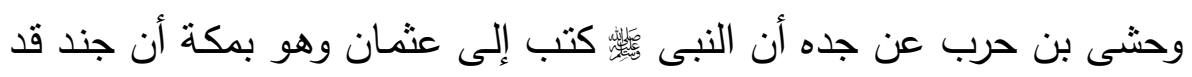

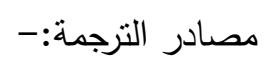

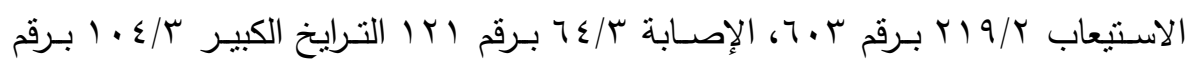

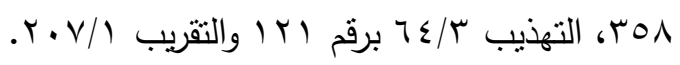

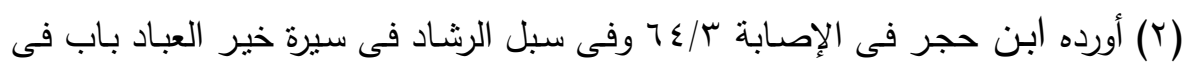
ذكر عبيدة 1//7/ ، ع ولم أقف على على تخريجه.

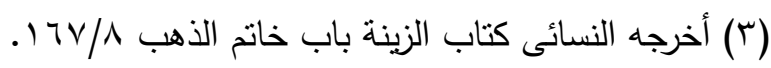

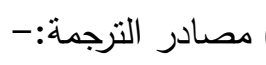

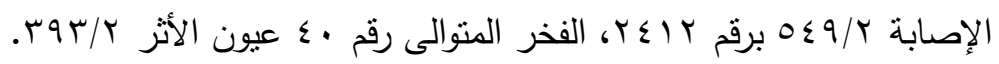




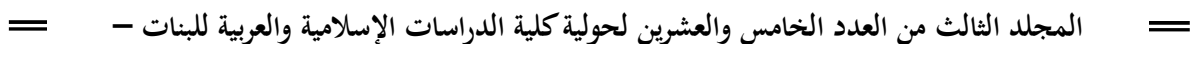

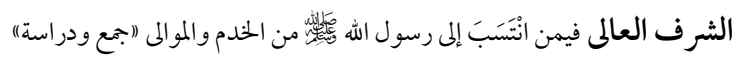

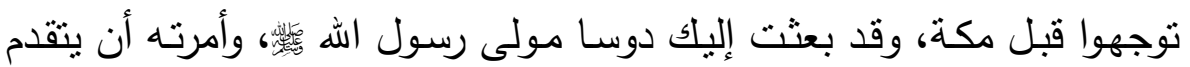

بين يديك اللواء (1).

قاست:ـ دوس هنائة من سياق الحديث داخل الترجمة دل عليه أنه مولى رسول

اله له

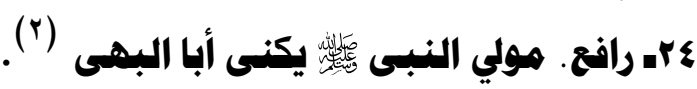

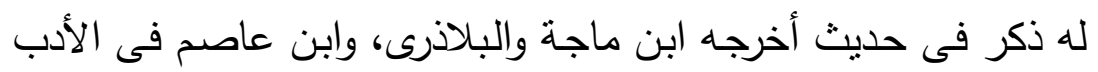

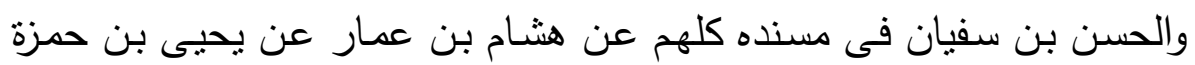

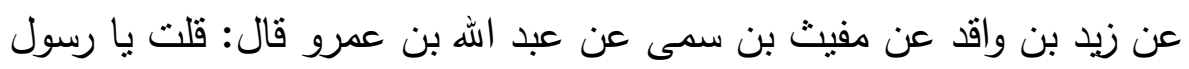

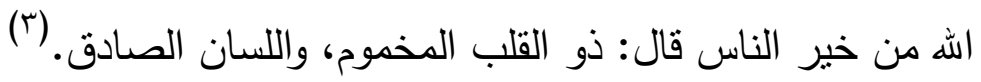

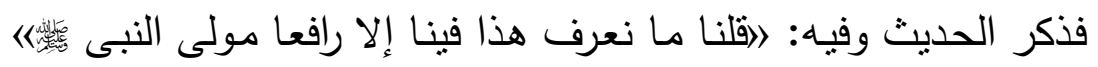
وهذه الزيادة ليست فى ابن ماجة.

قلت:ـ رافع أبو البهى هِئِ من سياق الحديث دل على أنه مولى رسول الله

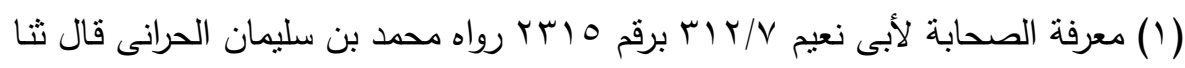

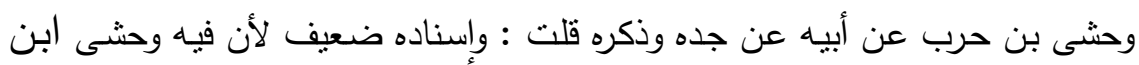

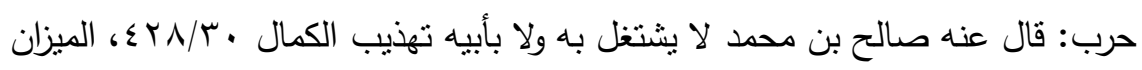

$$
\text { ع / اسب. }
$$

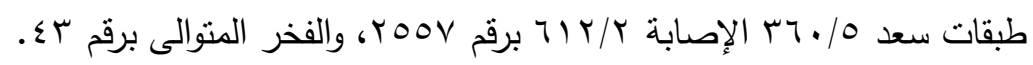

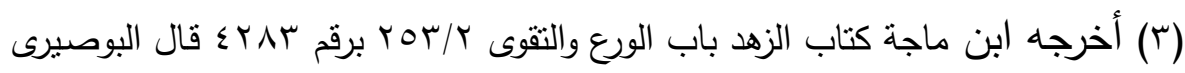

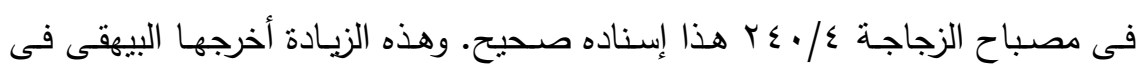

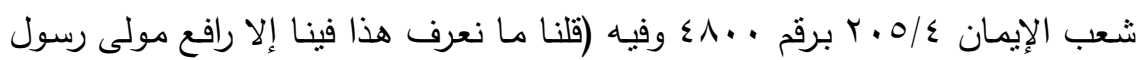

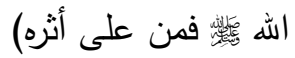
= 11 . 


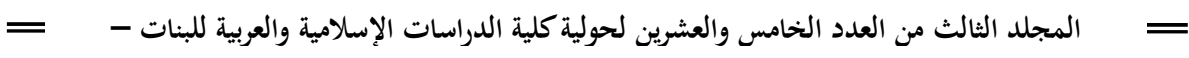

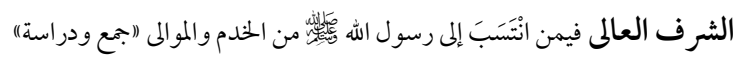

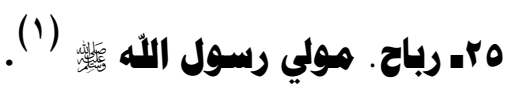

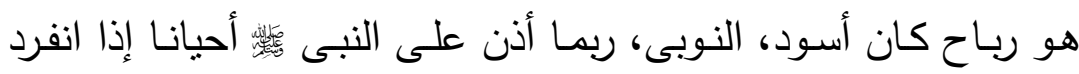

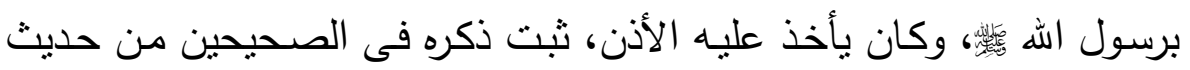

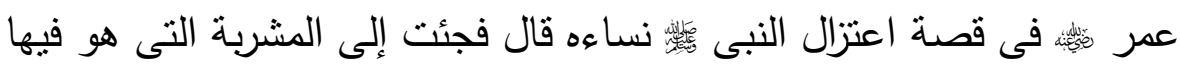

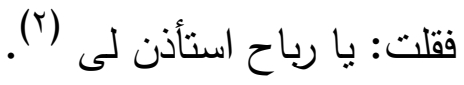

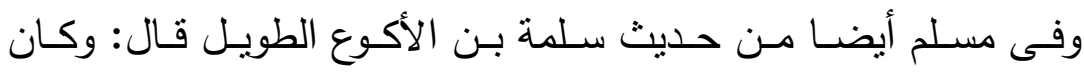
للنبى

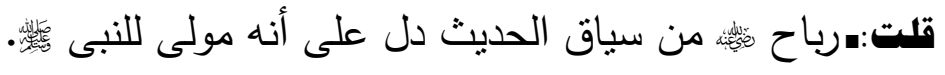

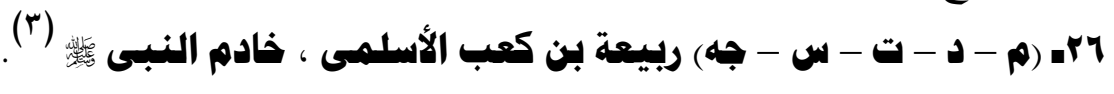

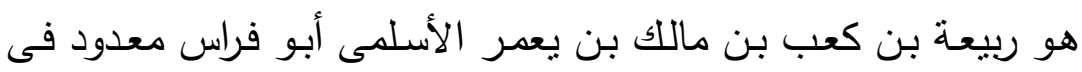

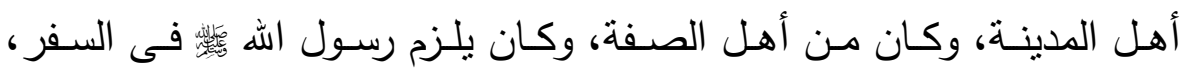
والحضر وصحبه قديما، وعمر بعده، مات بعد الحرة سنة ثلاث وستين.

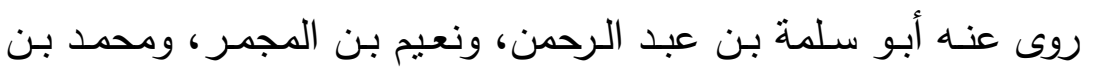

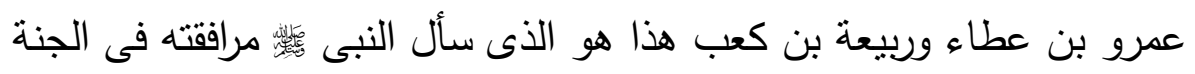

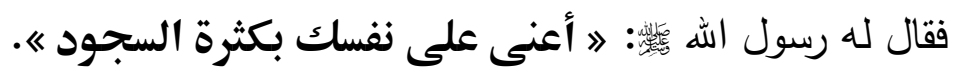

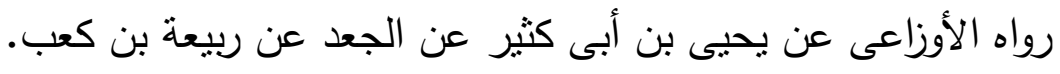

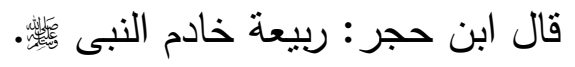

$$
\text { (1) - (1) مصادر التزجمة:- }
$$

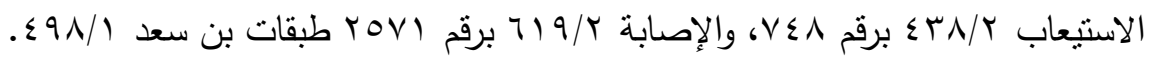

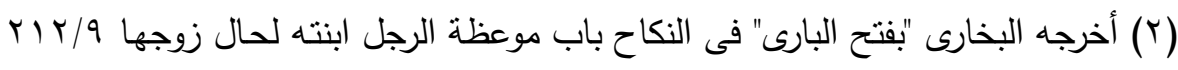

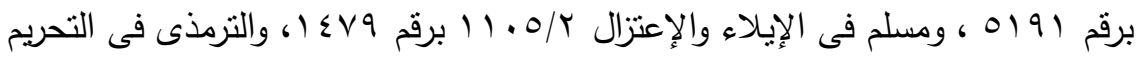

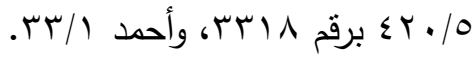

$$
\begin{aligned}
& \text { (Y) مصادر التزجمة:- }
\end{aligned}
$$

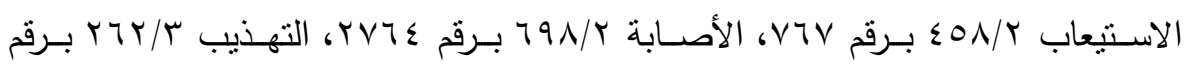




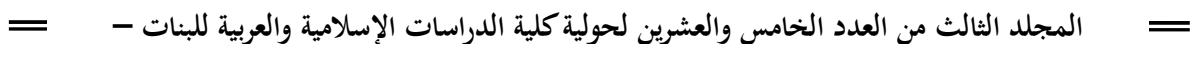

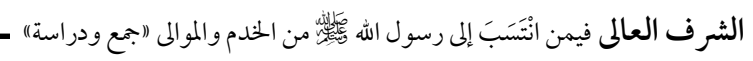

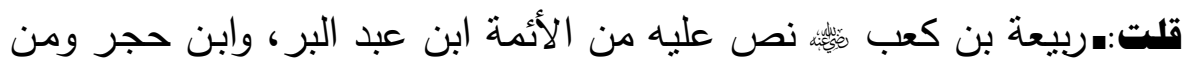

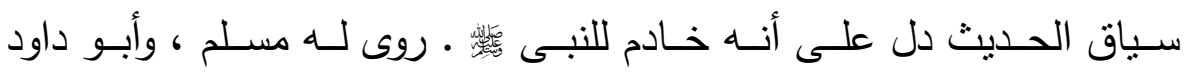
والترمذى، والنسائى، وابن ماجة.

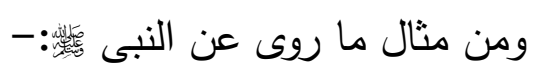

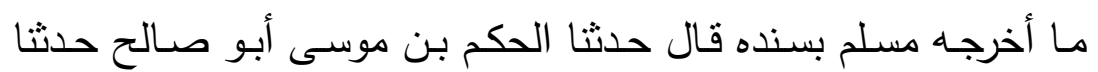
هيكل بن زياد قال سمعت الأوزاعى قال حدثنى يحيى بن أبى كثير حدثنى أبو

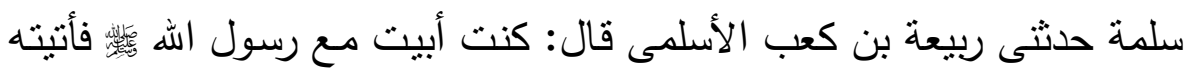

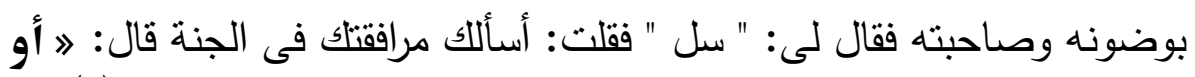

غير ذلك ؟ قلت هو ذاك: قال فأعنى على نفسك بكثرة السحود « ('). rr

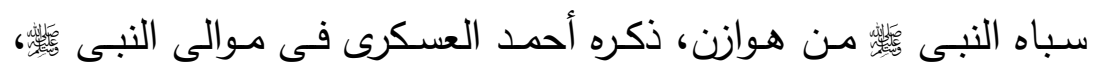

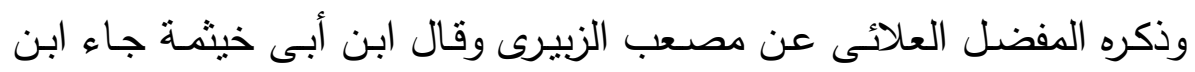
رويفع إلى عمر بن عبد العزيز يعرض له، ولا عقب لله حكاه ابن عساكر وقال

$$
\text { لا أعلم أحداً ذكره غيره. }
$$

رويفع مولى رسول الله

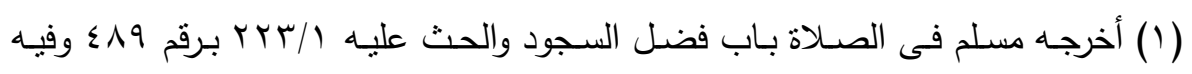

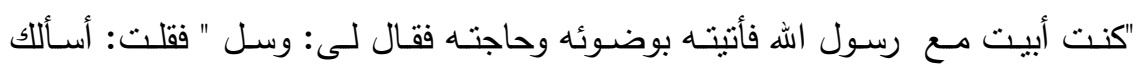
مرافقتلك فى الجنة، أو غير ذلك ؟ قلت هو ذاك فال: فأعنى على نفسك بكثرة السجود"

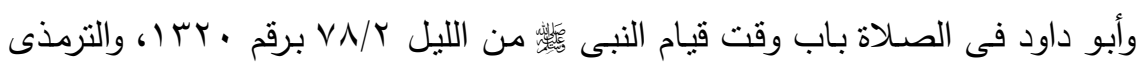

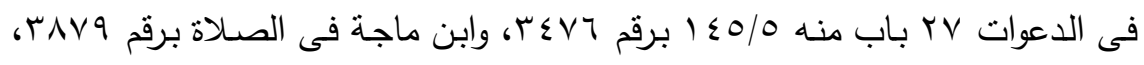

$$
\begin{aligned}
& \text { وأحمد } \\
& \text { مصادر الترجمة:- }
\end{aligned}
$$

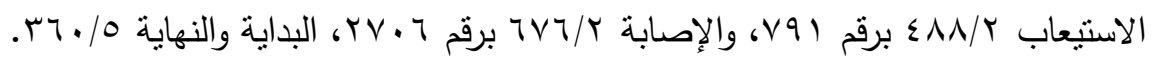




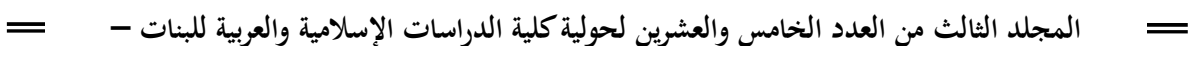

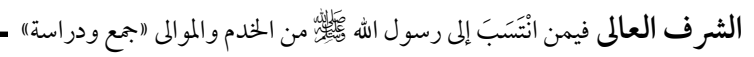

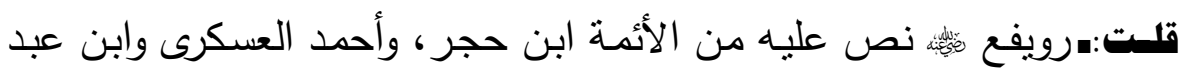

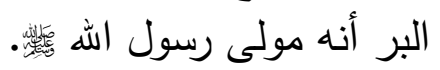

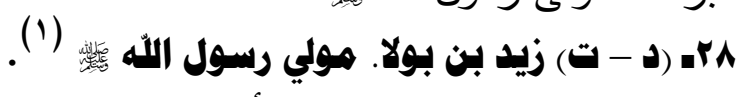

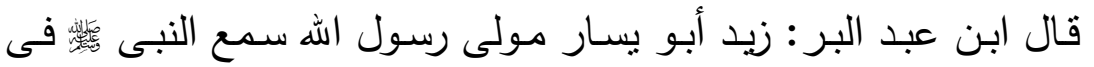

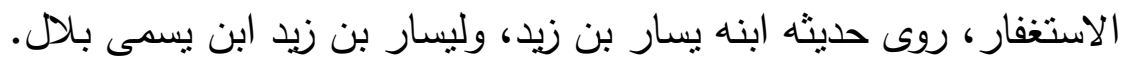

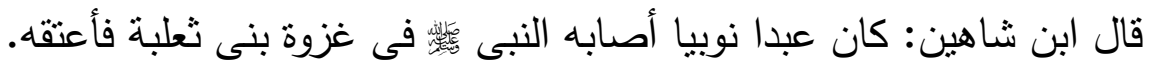

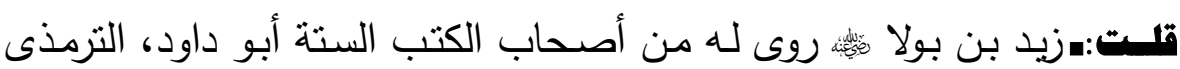

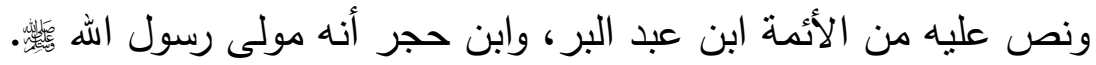

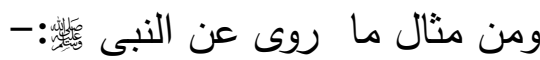

قال أبو داود: حدثنا موسى بن إسماعيل حدثنا حفص بن عمر عمر بن سمره

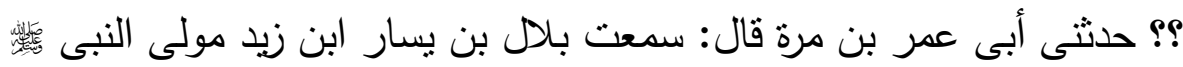

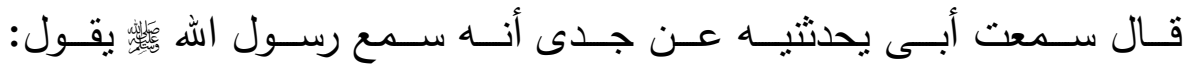

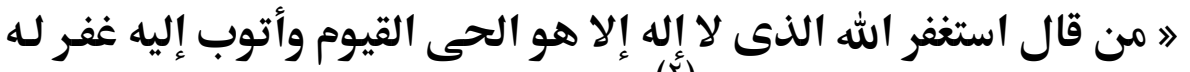

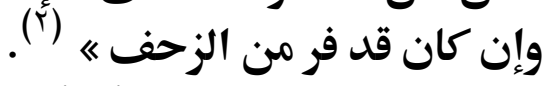

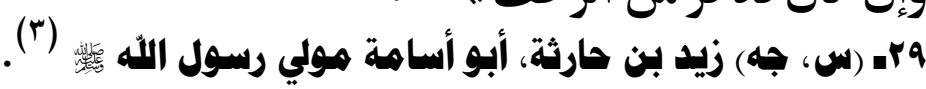

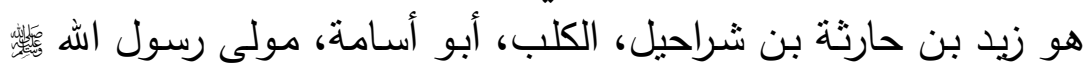

شهد المشاهد كلها، وكان من الرماة المذكورين. روى عن النبى

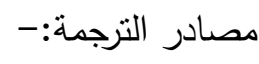

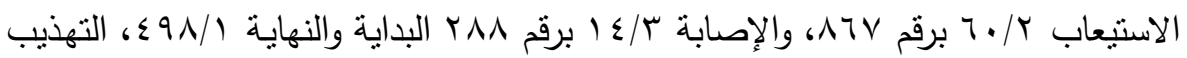
ا

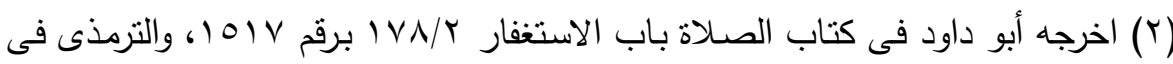

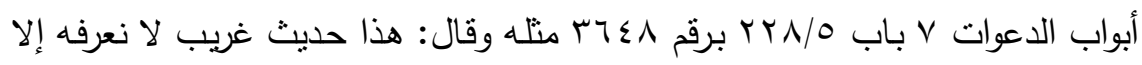
من هذا الوجه.

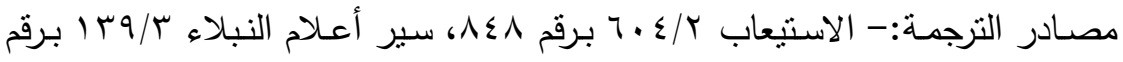

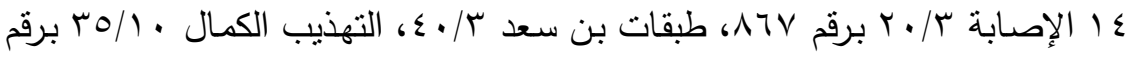

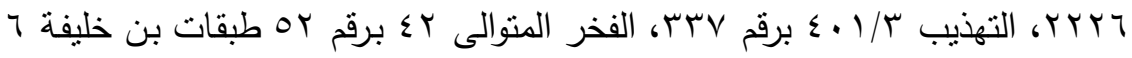
برقم ·. 


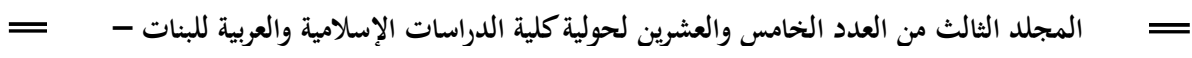

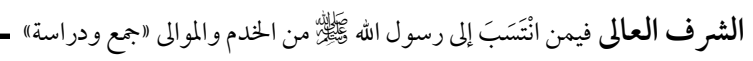

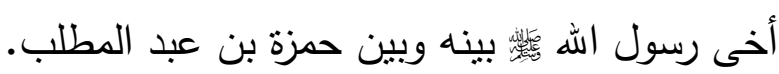

وقال عبد الله بن عمر غئئه : ما كنا ندعو زبد بن حارئة إلا زبد بن محمد حتى

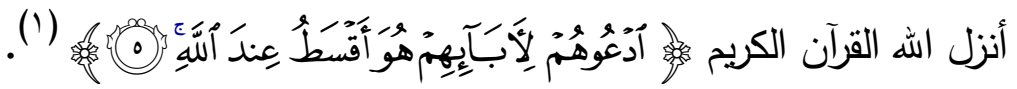

قال الزهرى:- ما علمنا أحداً أسلم قبل زيد بن حارثة.

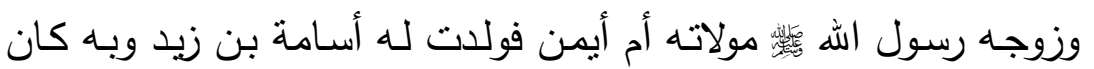

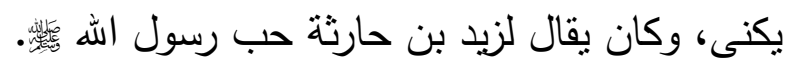

استشهر يوم مؤتة سنة ثمان وهو ابن خمس وخمسين.

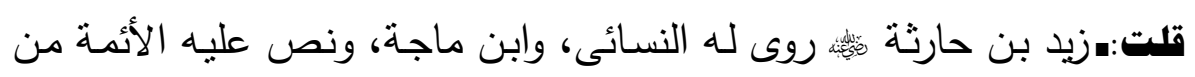

خلال الآيات القرآنية والأحاديث النبوبة أنه مولى رسول الله فئسئ. ومن منال ما روى عن النبى

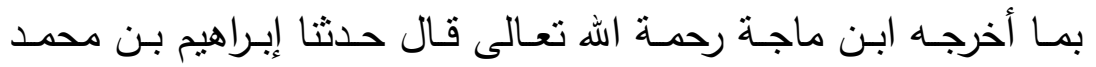

الفريابى حدثثى حسان بن عبد الله حدثنا ابن لهيعة عن عقيل عن الزهرى عن

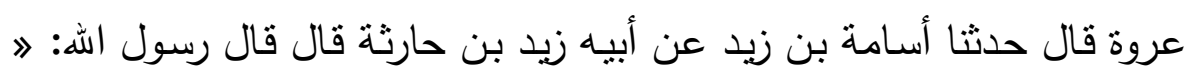
علمنى جحر ائيل الوضوء وأمرنح أن أنضح تحت ثوبى لمـا تحرج مـن البول بعل الوضوء

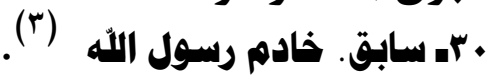

ذكره خليفة بن خياط فى الصحابة، وفى موالى النبى

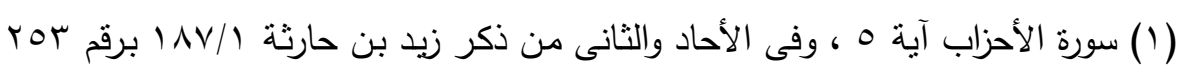

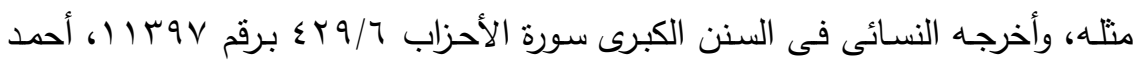
فى مسنده

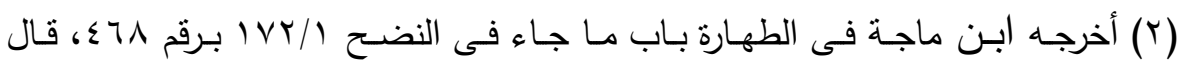
السيوطى وفى الزوائد ضعيف لضعف ابن لهيعة.

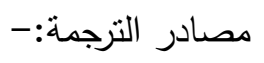

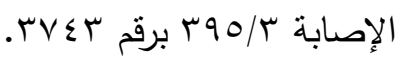




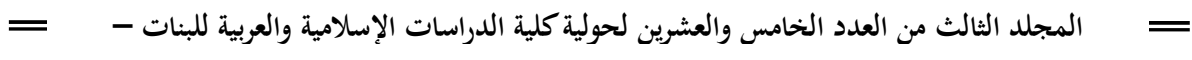

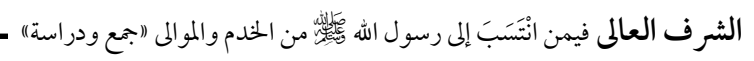

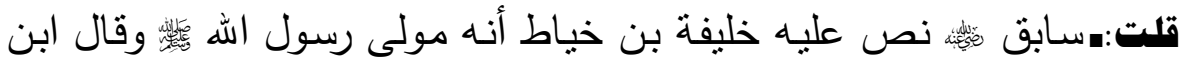

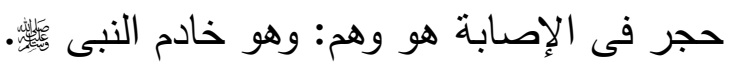

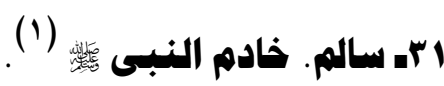
قلت:ـلم أقف على سوى ما ذكره ابن حجر في الإصـابة: أنه خادم رسول الله . 龊

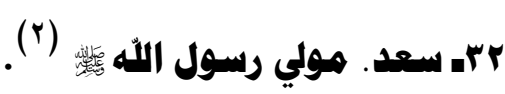
يقال له: أبو عبيد، روى عنه أبول عثمان النهانه النهى.

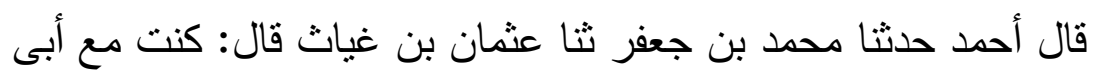

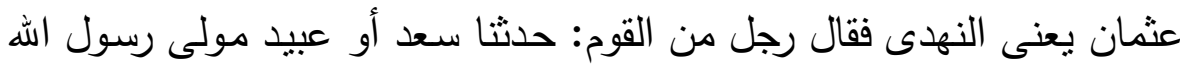


الجهر الحديث (r).

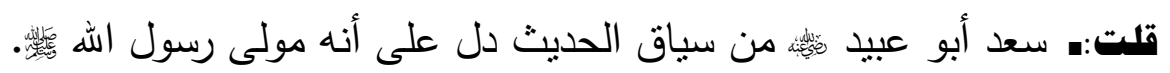

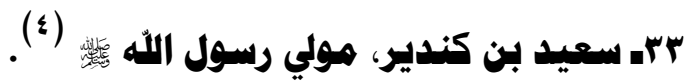
قيل هو : سليمان بن ربيعة كنيته أبو كندير . قلت:-

سعيد بن كندير أبو كندير ذكره السخاوى بأنه مولى رسول الله

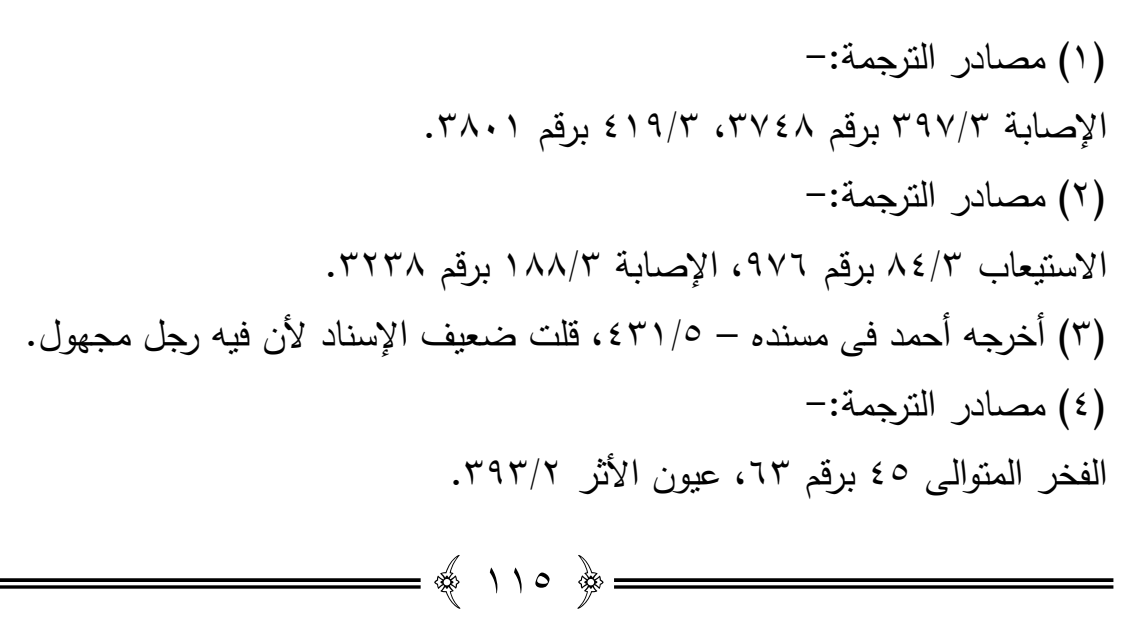




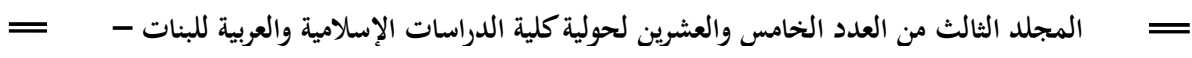

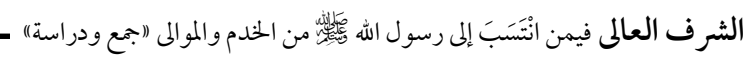

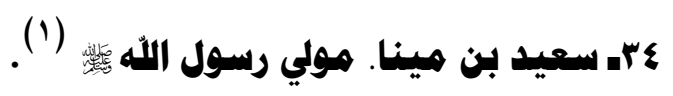

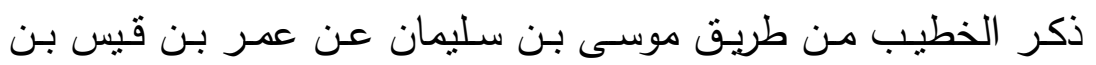

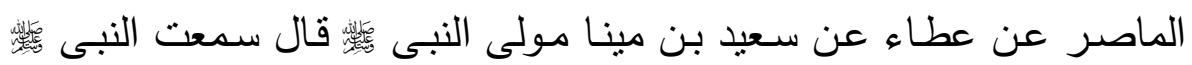

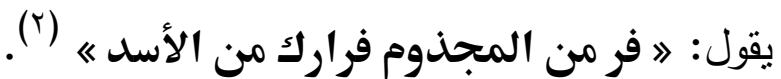

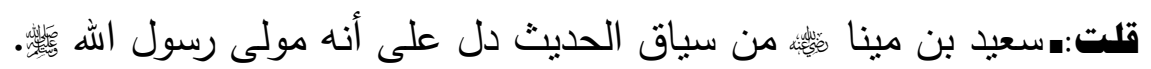

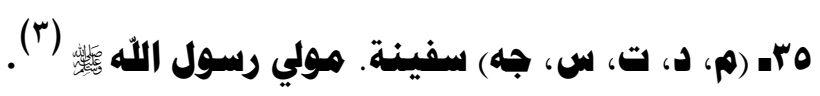

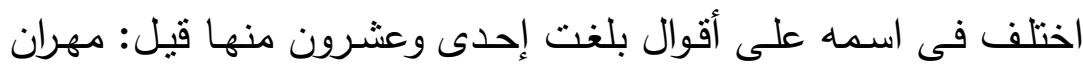

وقيل: طهمان، وقيل: مروان.

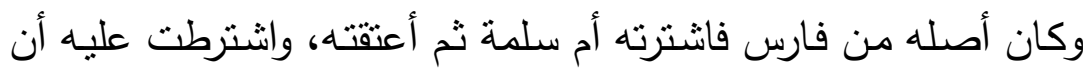

يخدم النبى

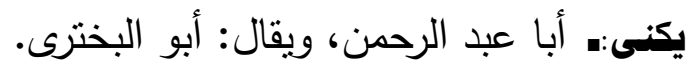

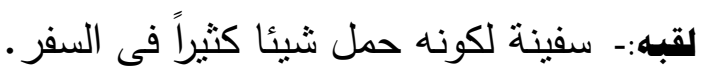

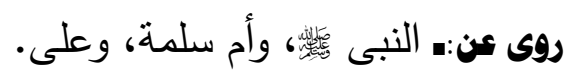

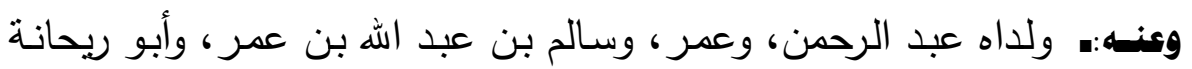

وآخرون.

مصادر الترجمة:-

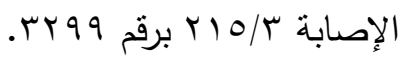

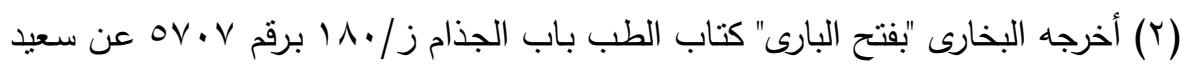

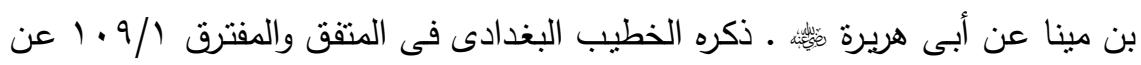

$$
\begin{aligned}
& \text { سعيد بن مينا . } \\
& \text { (باد) مصادر الترجمة:- مينا. }
\end{aligned}
$$

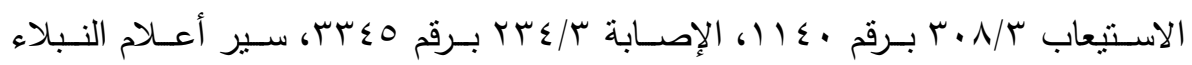

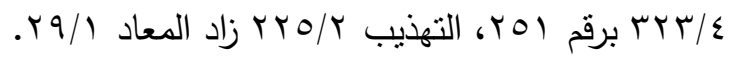

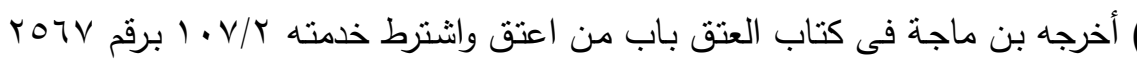

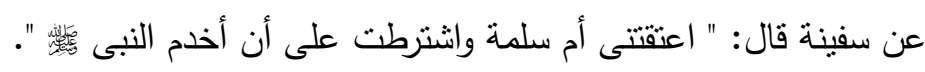




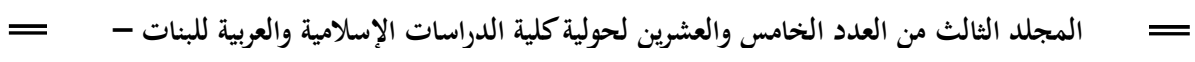

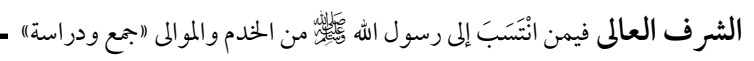

قال حماد بن سلمة عن سعيد بن جمهان عن سفينة كنت مع النبى فئس فى سفر فكان بعض القوم إذا أعيا ألقى على ثوبه حتى حملت من ذلى ذلك شيئا

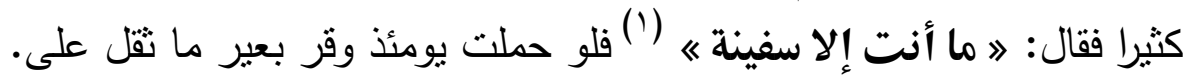

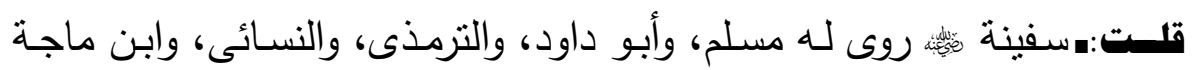

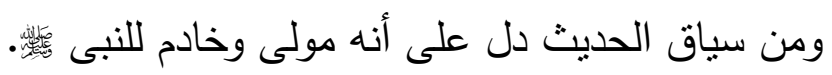

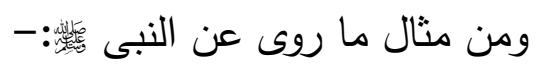

قال الإمام مسلم رحمه الله تعالى قال: حدثنا أبو كامل حدثثا بشر حدثثا

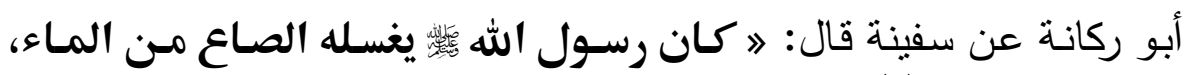

ويوضؤه المد « (r).

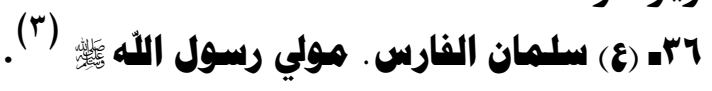

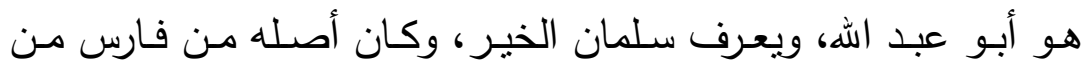
رامهر مز ويقال لها : جى.

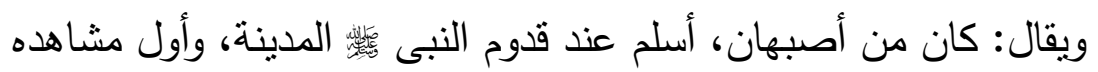
الخندق والمشاهد كلها.

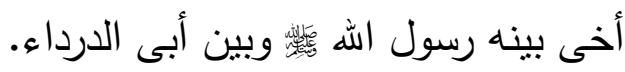

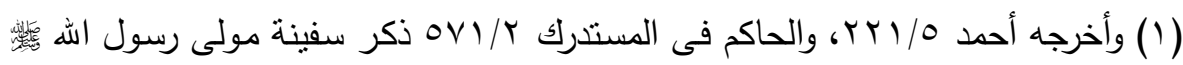

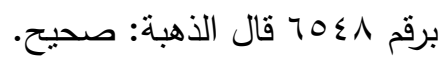

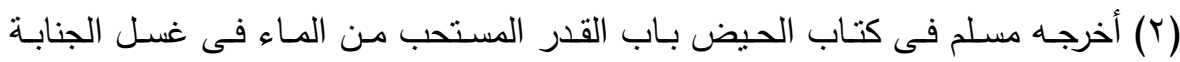

$$
\text { 109/1 }
$$

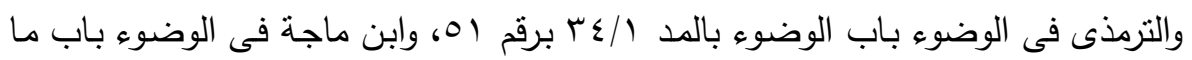

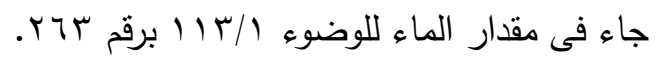

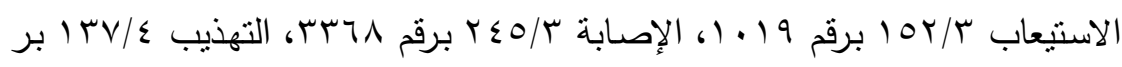

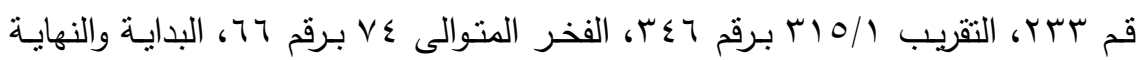
TrY/O 


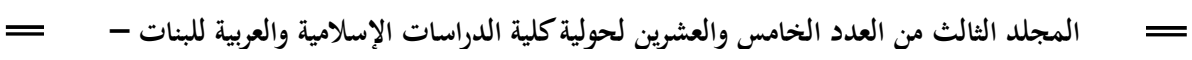

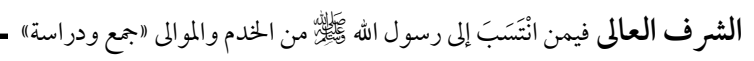

قال ابن عبد البر : روى من وجوه أن رسول الله فئس اشتراه على العتق،

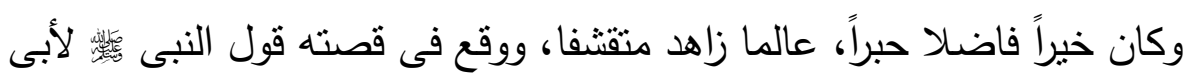

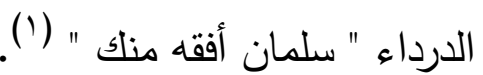
روى عـن النبـى عباس، وأبو سعيد وآخرون.

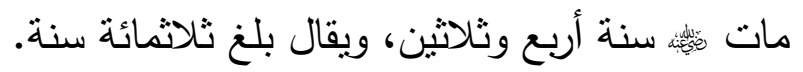

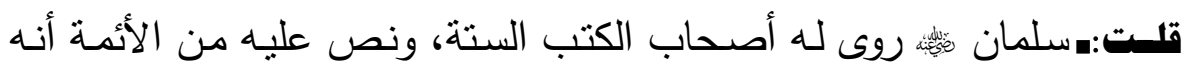
مولى رسول الله

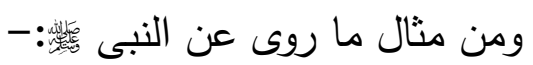

قال الإمام مسلم رحمه الله تعالى حدثنا أبى بكر بن أبى شيبة حدثنا أبى أبو

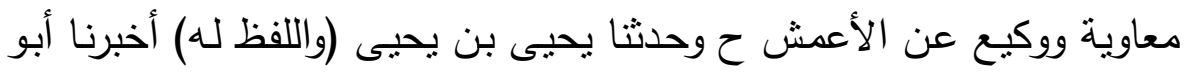

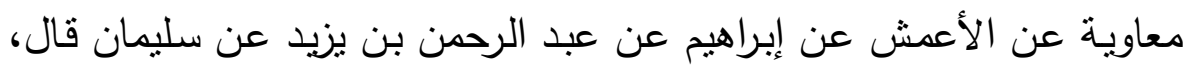
قيل له، قد علمكم نبيكم

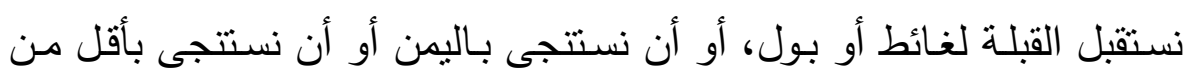

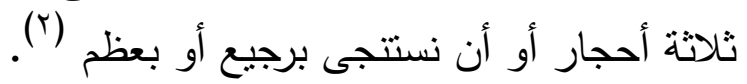

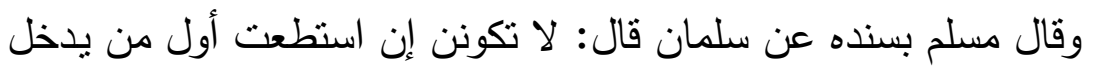

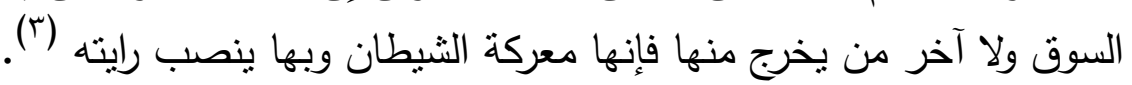

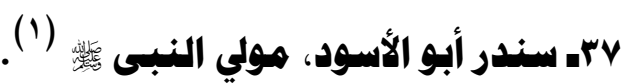

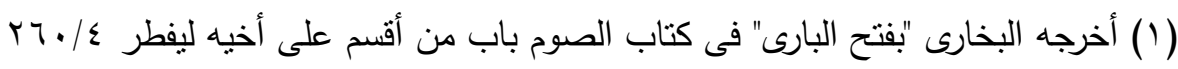

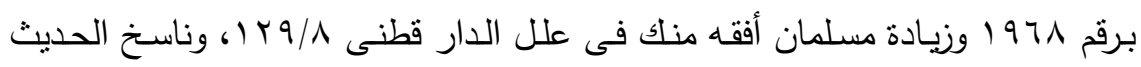
ومنسوخه /T// ب حديث آخر فى صوم يوم الجمعة منفردا.

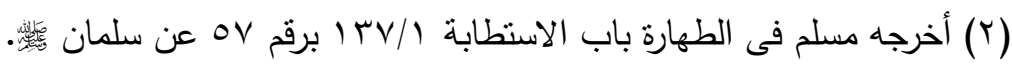

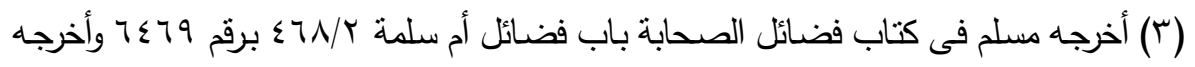

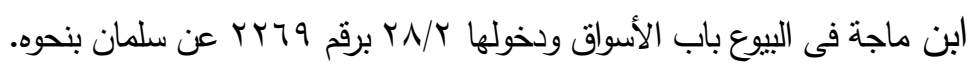




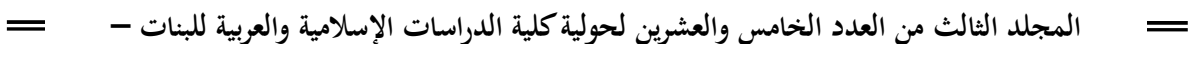

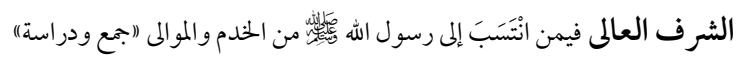

هو سندر مولى زنباع الجذامى. قال ابن عبد البر له صحبة حديثه عن

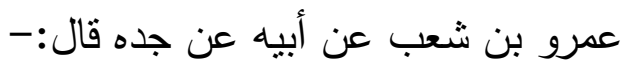

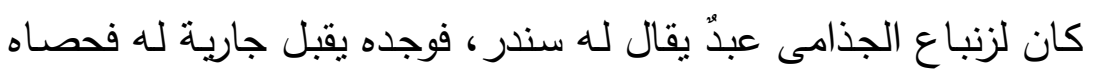

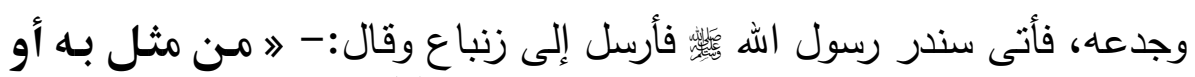

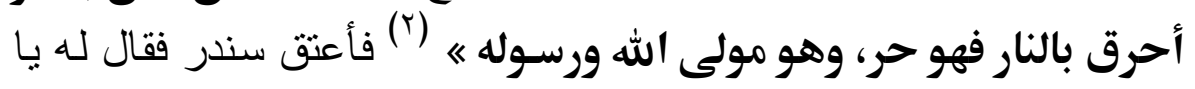

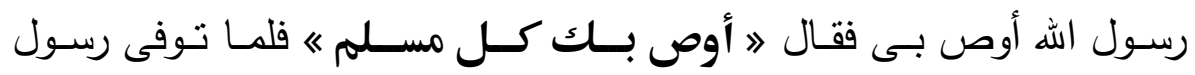

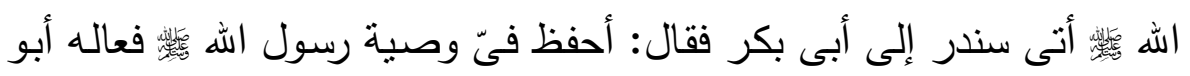

$$
\text { بكر حتى توفى: ثم أتى بعده إلى عمر ... «. }
$$

وقال ابن حجر :- ذكر محمد بن الربيع الجيزى فى الصـحابة الذين

دخلوا مصر أن لأهل مصر عن سندر حديثين.

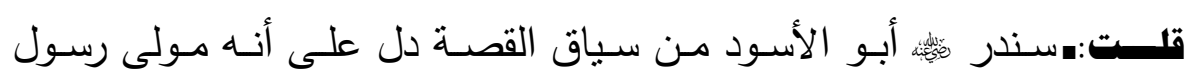

اله ه

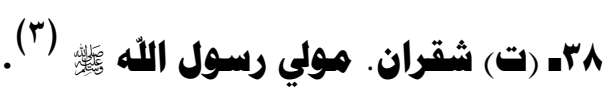

$$
\text { قيل: اسمه صالح بن عدى. هوان. }
$$

قال مصعب الزبيرى: كان عبداً حبشياً لعبد الرحمن بن عوف فوهبهـ

الرسول الهه

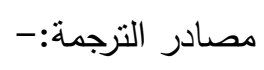

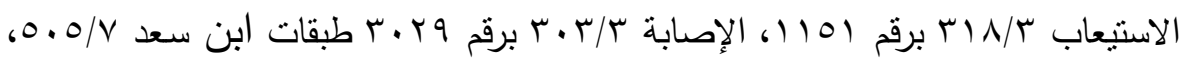

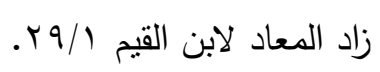

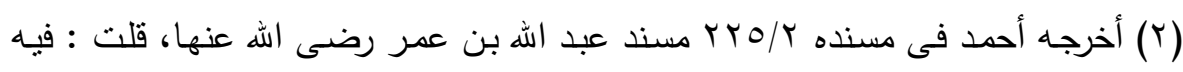

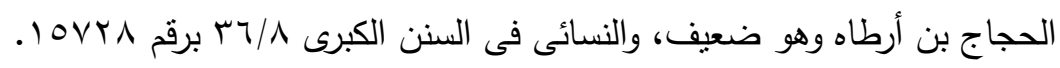

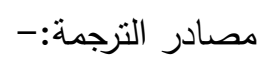

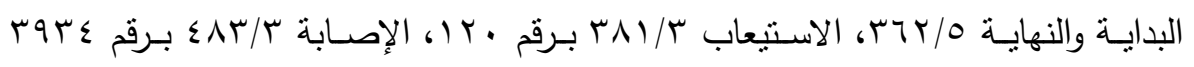

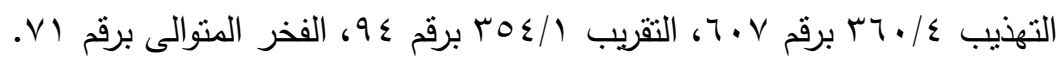




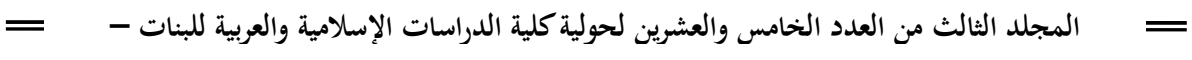

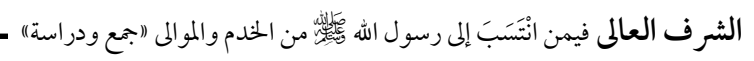

وقال أبو معشر:-- شـه شقران بدراً، وكان يومئذ عبداً فلم يسـهم لـه، سكن

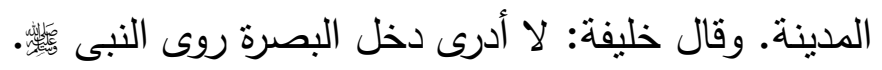

وعنه:- عبيد الله بن رافع، يحيى بن عمارة المزنى، وأبو جعفر محمد بن على وكان ممن حضر عسل النبى

وقال أبو معشر: شهد شقران بدرا، وكان يومئذ عبدا فلم بسهم له.

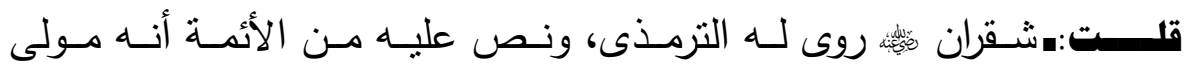
رسول الله ابن عبد البر، وابن حجر، والسخاوى.

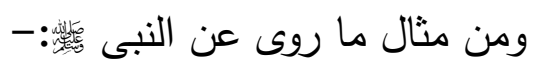

مـا أخرجهـ الترمذى بسـنده قال جعفر وأخبرنى ابـن رافع قال: سـمعت

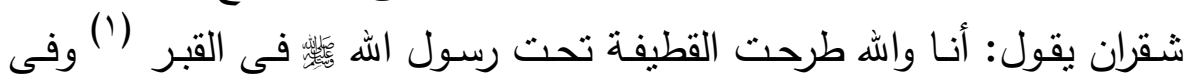
الباب عن ابن عباس.

قال أبو عيسى: حديث شقران حديث حسن صحيح غربب.

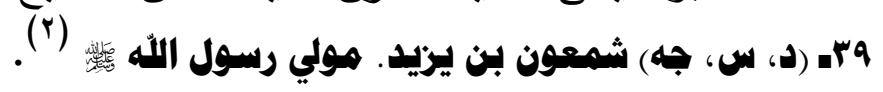
هو : شمعون بن يزبد بن خنافة القرظى من بنى قربظة، أبو ربحانة، الأنصارى، الخزرجى، حليف لهم.

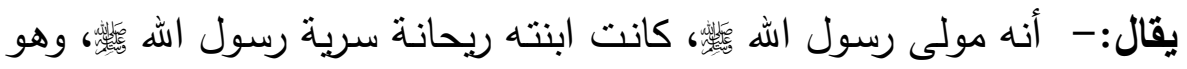

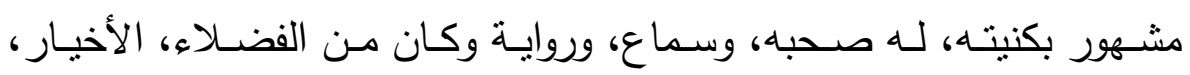
النجباء، الزاهدين فى الدنيا، الراجين ما عند الله، نزل الثام روى عنه الثاميون

(1) أخرجه الترمذى فى الجنائز باب الثوب الواحد يلقى تحت الميت فى القبر / / ب ب برقم ror 1 و وقال أبو عيسى: حديث شقران حديث حسن صحيح غريب.

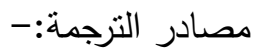

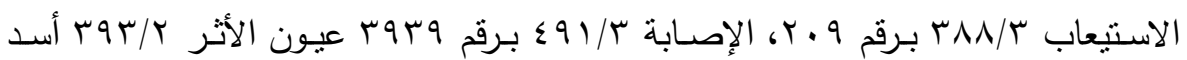

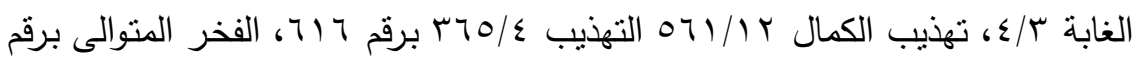

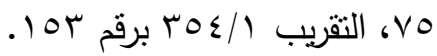
= 1 . 


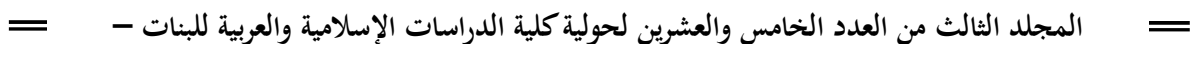

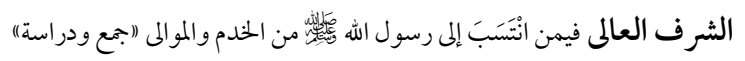

روى عن النبى

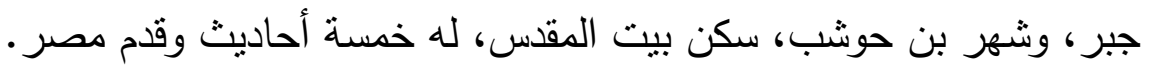

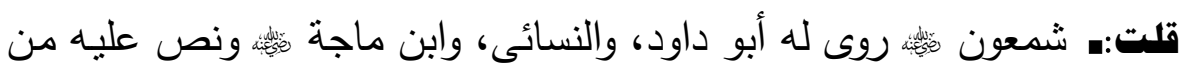
الأئمة أنه مولى رسول الله

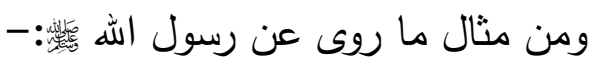

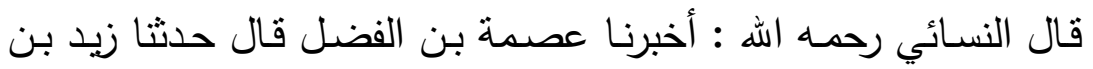
الحباب عن عبد الرحمن بن شريح قال سمعت محمد بن شمير الرعينى سمعت

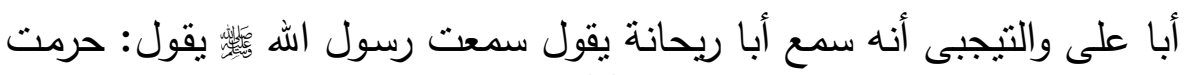
عين على النار سهرت فى سبيل الله (')

• ع - صالح. هولي رسول الاله.

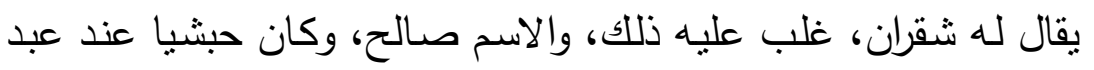

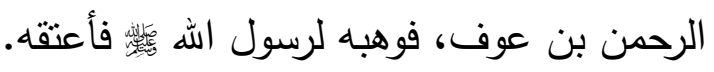

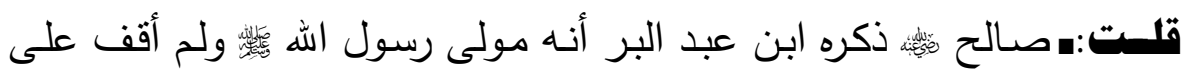

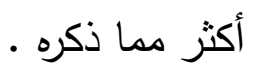

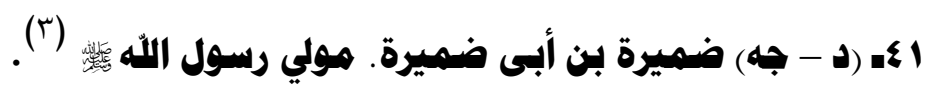

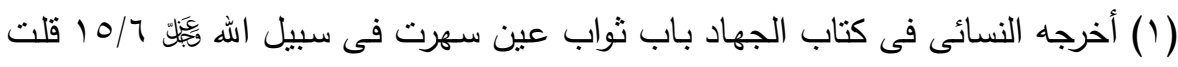

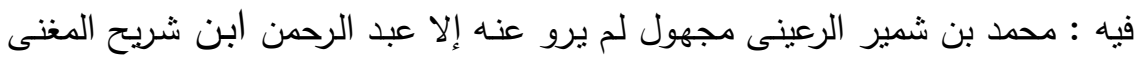

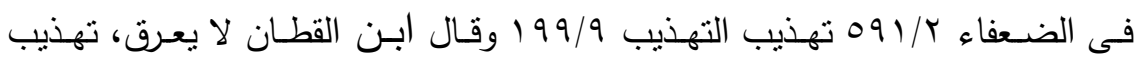

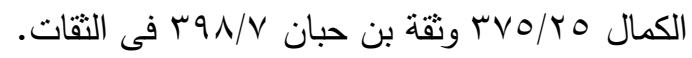

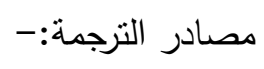

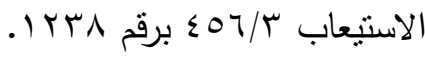

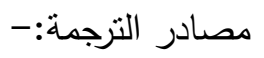




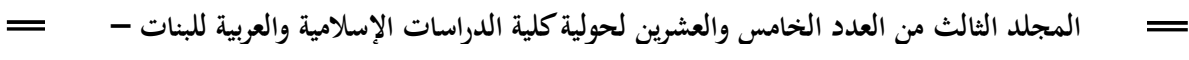

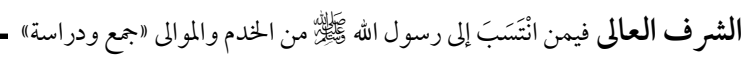

لله ولأبيه صسحبة، وهو جد حسين بن عبد الله بن ضميرة بعد فى أهل المدينة شهد هو وابنه سعد حنينا.

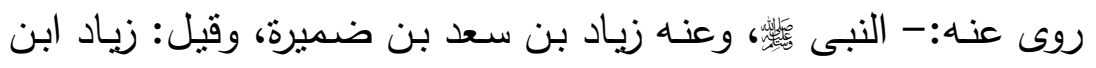

ضميرة ابن سعد وقيل غير ذلك.

ذكر ابن مصعب قال أخبرنى بن أبى ذئب عن حسين بن عبد الله بن

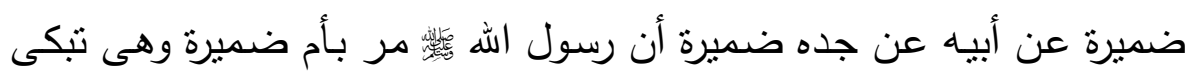
فقال: ما يبكيك ؟ أجائعة أنت أم عاربة ؟ قالت: يا رسول الله فرق بينى وبين

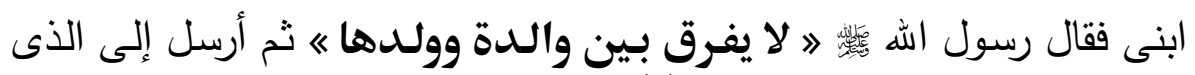

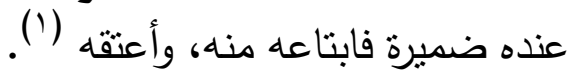
قات:ـضمير بن أبى ضميرة روى لله أبو داود، وابن ماجة، ومن سباق القصة

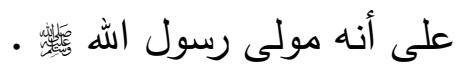

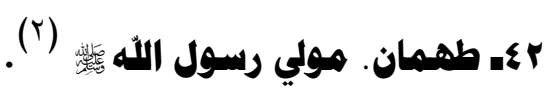
روى حديثه عطاء بن السـائب فى الصدقة، واختلف فيه فقيل طهمان، وقيل: ذكوان، وقيل غير ذلك.

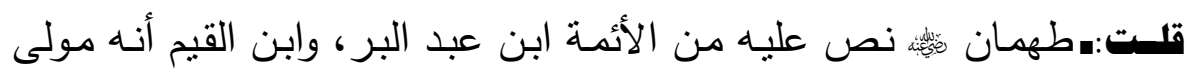
رسول الله

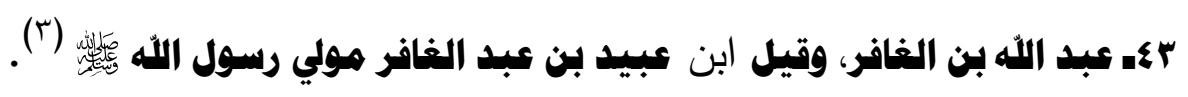

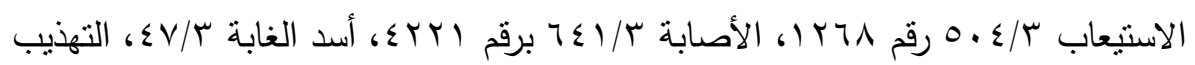

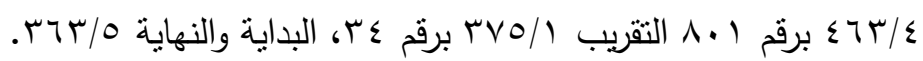

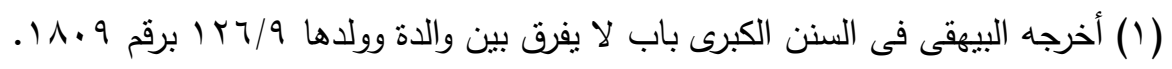

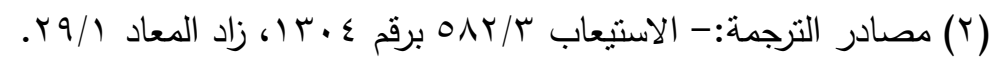

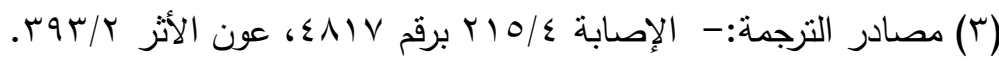




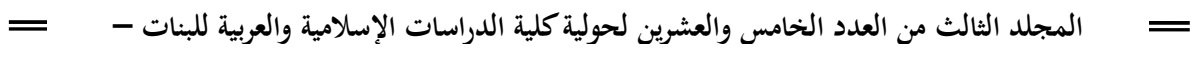

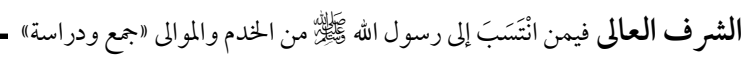

روى أبو موسـى من طريـق على بن محمد المنجورانى عن حمـاد بن

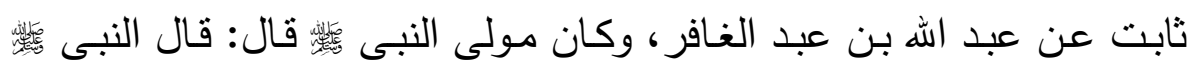

》 إذا ذكر أصحابى فأمسكوا.... « (1)

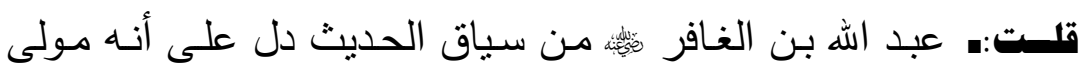

رسول الهة

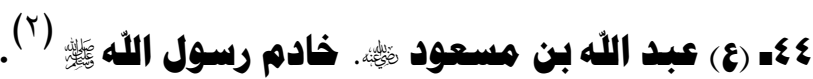

هو : عبد الله بن مسـود بن غافل بن حبيب بن شـخ بن مخزوم بن

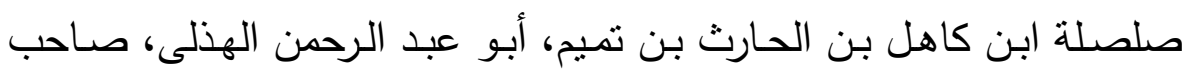
نعله، وسواكه.

أمه: أم عبد بنت عبد ابن سوار بن هذبل.

زوجته:- زبنب بنت عبد الله الثقفية.

أسلم بمكة قديما، مهاجر الهجرتين، وشـه بدرا، والمشـاهد كلها، وكان

صاحب نعل رسول الله

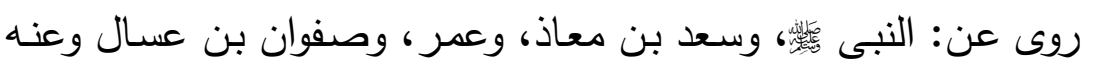

$$
\text { ابناه عبد الرحمن، وأبو عبيدة، وآخرون. }
$$

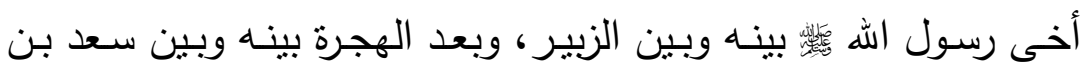

معاذ مات بالمدينة قبل عثمان سنة بم هـ وقيل مات سنة سب هـ بالكوفة.

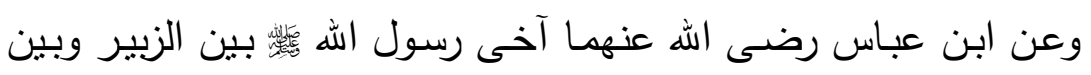

$$
\text { عبد الله بن مسعود رضىى الله عنهما. }
$$

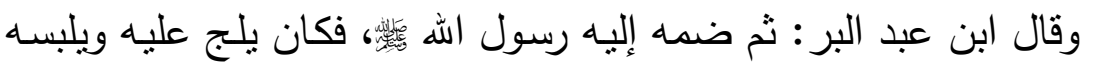

نعليه ويمشى أمامه، ويستره إذا اغتسل، ويوقظه إذا نام.

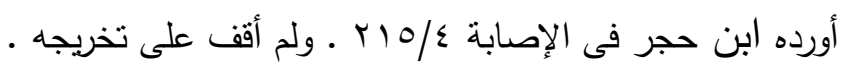

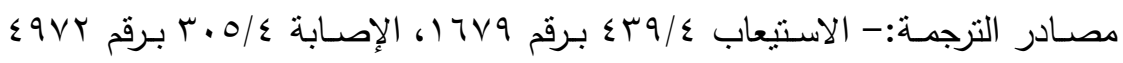

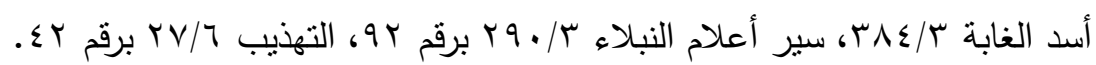




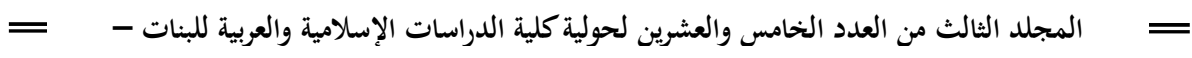

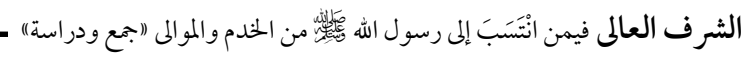

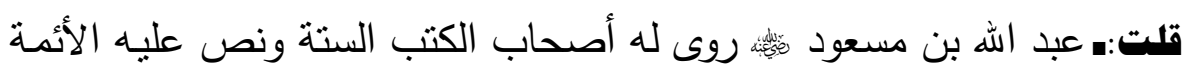

أنه خادم رسول الله

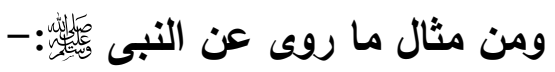

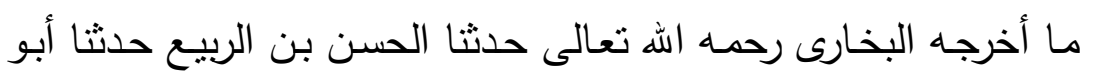

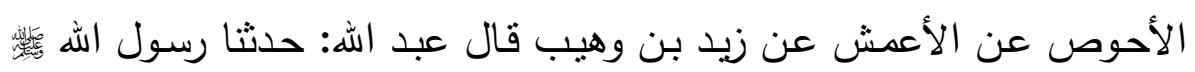

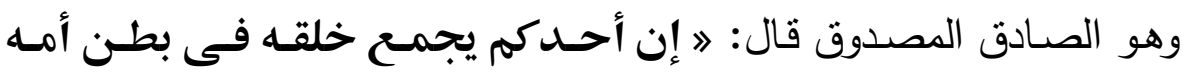
أربعين يوما، ثم يكون علقة مثل ذلك، ثم يكـون مضغة مثل ذلك ذلك، ثم

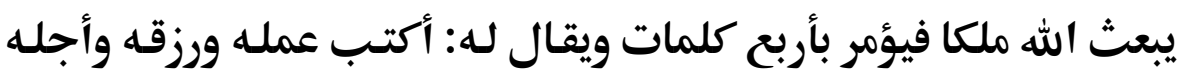

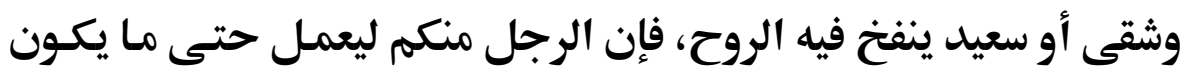

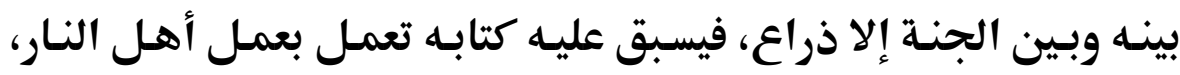

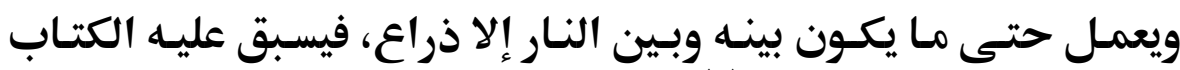

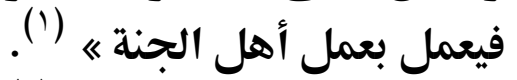

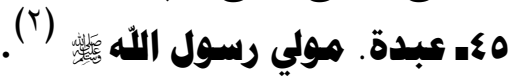

ذكره ابن شاهين، وأخرج من رواية المبارك عن سليمان التيمى عن رجل

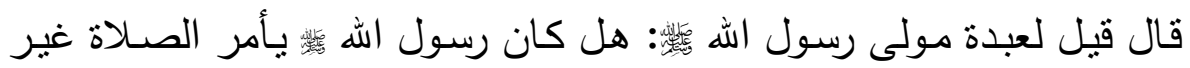
المكتوبة قال: بن المغرب والعشاء. لمولئ

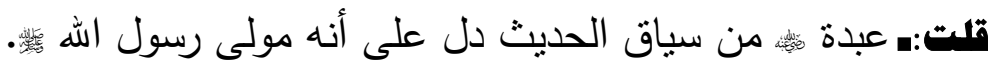

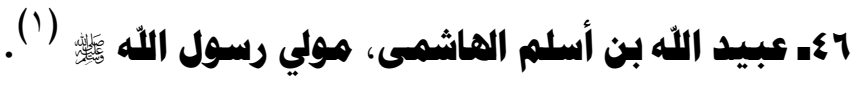

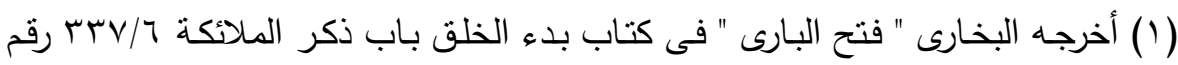

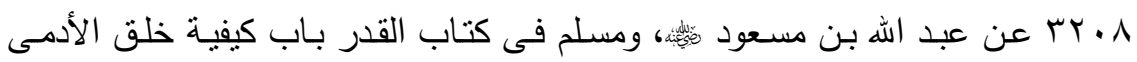

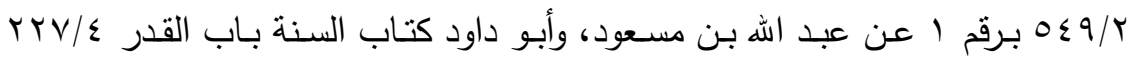

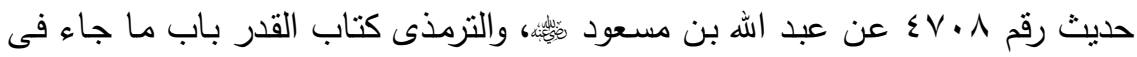

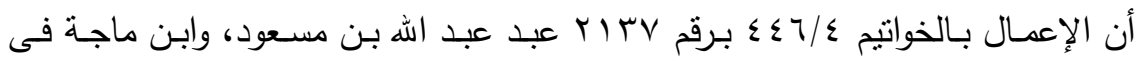

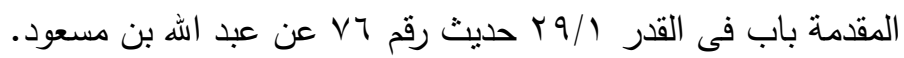

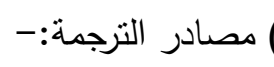

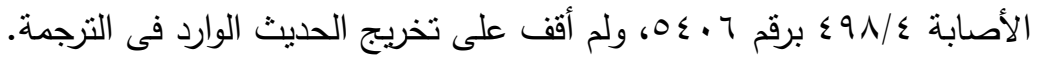




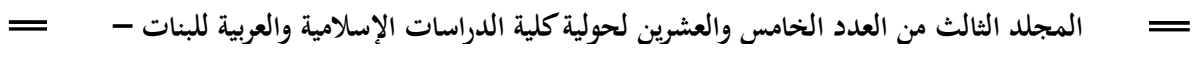

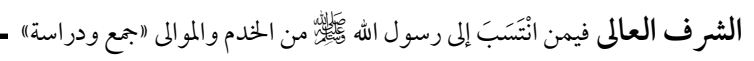

ذكره البغوى وغيره والصحابة، وأخرج أحمد وغيره من طريق بن لهيعة

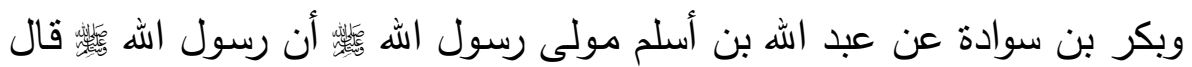

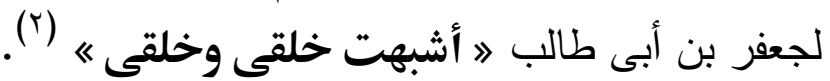

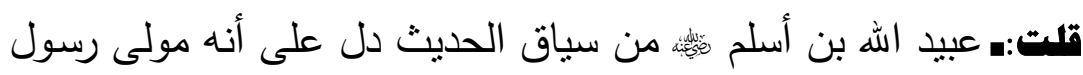

اله

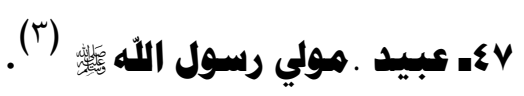
هو : ابن حبان له صحبة ، وذكره ابن السكن فى الصحابة ولم يثبت حديثه

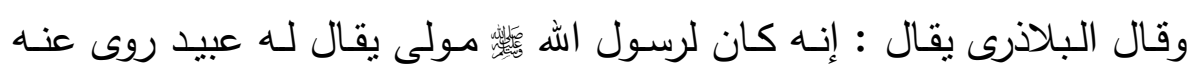
حديثين وفان

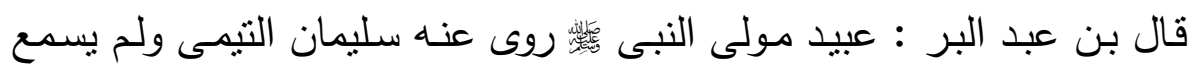

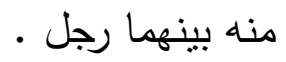
قلت : عبيد نابه نص عليه من الأئمة ابن عبدالبر ، وابن حجر على أنه مولى • رسول الله

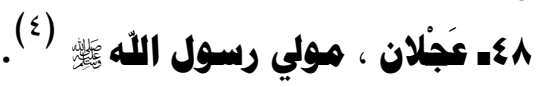

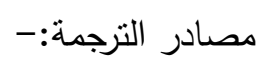

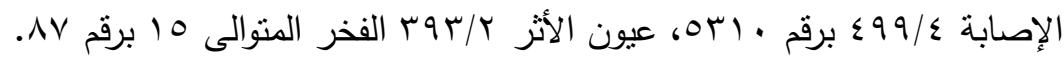

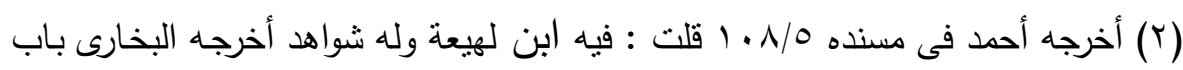

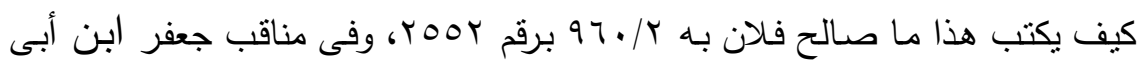

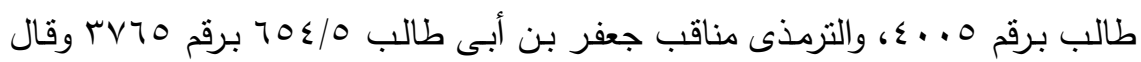

$$
\text { أبو عبسى حديث حسن صحيح. }
$$

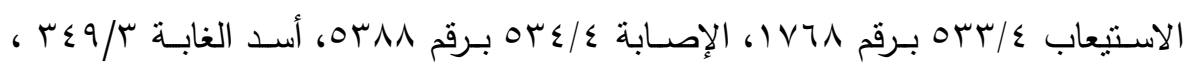

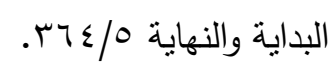

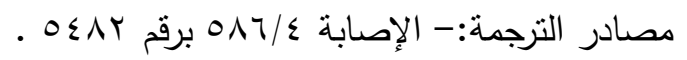

$\overline{=}$ 1 ro 


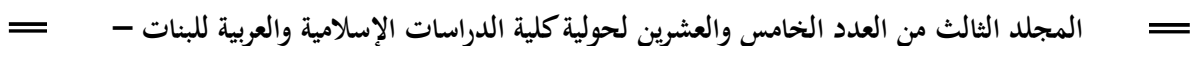

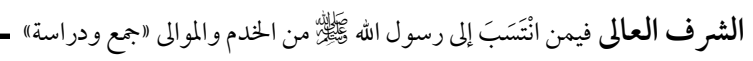

روى عنه حديث : القضاة ثلاثثة . وعنه ابنه .

أخرجج عبد الصـمد بـن سـعبد فى طبقات الحمصـيين مـن طربـق عمـرو بن شرحبيل الخولانى سمعت عجلان بهذا .

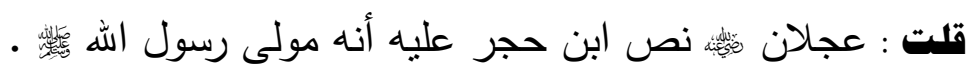

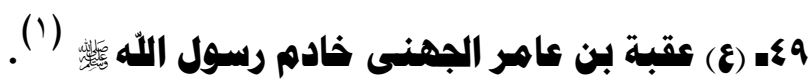

هو: عقبة بن عامر بن عيسى الجهنى، من جهينة بن زيدا بن سود ابن

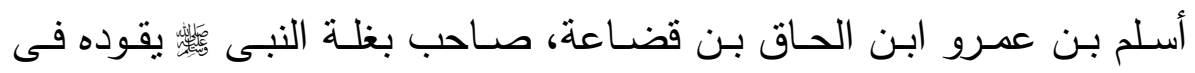
الأسفار

بكنى: أبا حماد، وقيل ! أبا سبد، وقيل: أبا عمرو، وقيل: أبا سعد روى

عن النبى

وعنه أبو أمامة، وابن عباس، وقيس بن حازم وآخرون.

قال الذهبى:- ولى إمرة مصر ، وكان يخضب بالسواد، وقبره بـالمقطم

مات سنة ثمان وخمسين.

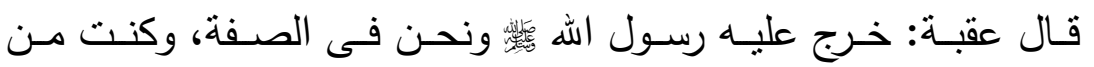

أصحاب الصفة، وكان عقبة من الرماة المذكورين.

قات:ه عقبة بن عامر نَّئيَّ روى له أصحاب الكتب الستة ونص عليه ابن

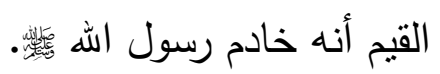

ومن مثال ما روى عن التبى

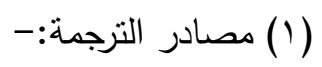

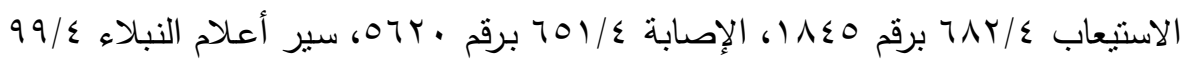

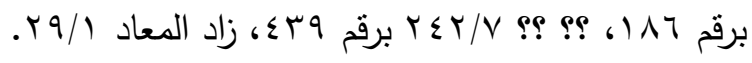

$\overline{=197}$ 


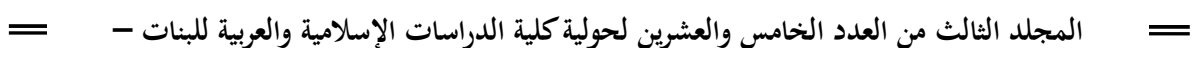

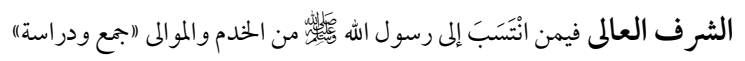

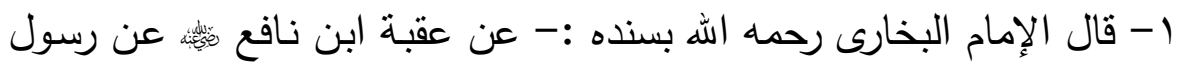

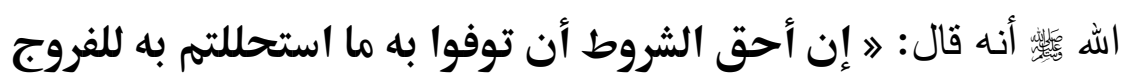

r- وبمـا رواه الإمـام مسـلم رحمـه الله قـال: حـثثا زكريـا، يحيـى بـن صـالح

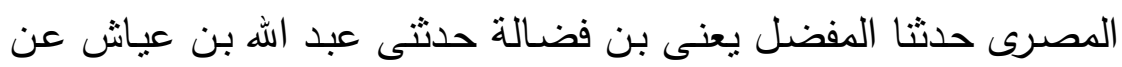

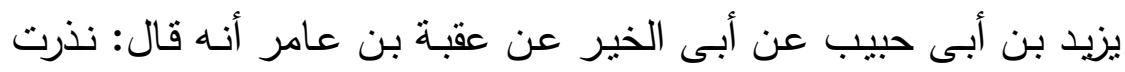

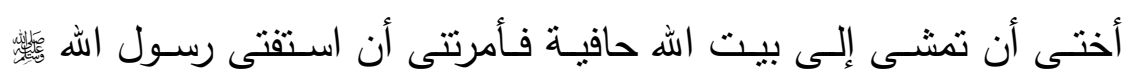

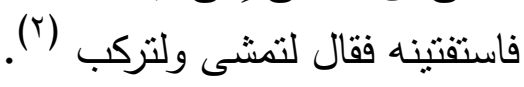

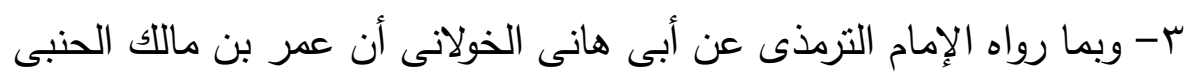

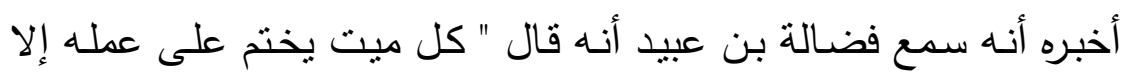

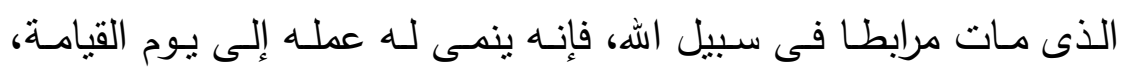

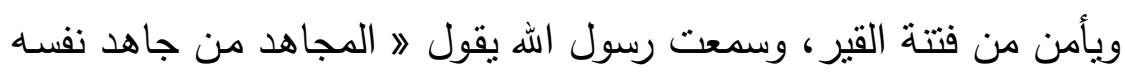

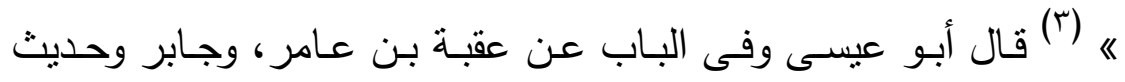
فضالة حسن صحيح.

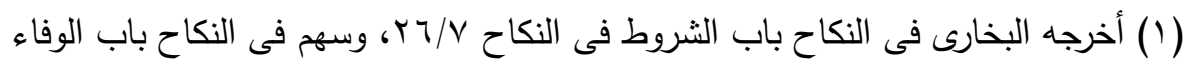

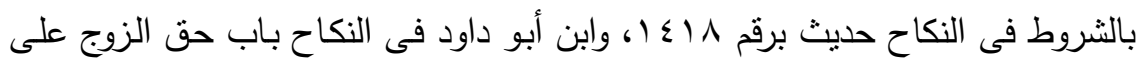

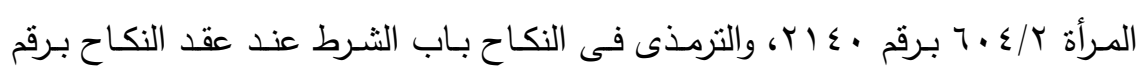

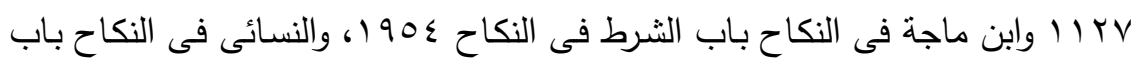

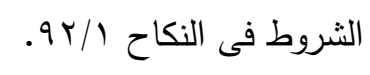

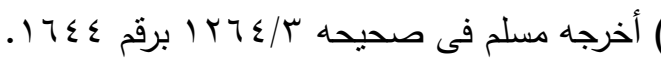

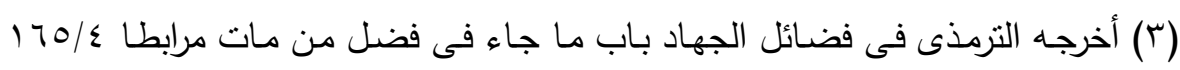

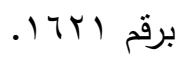




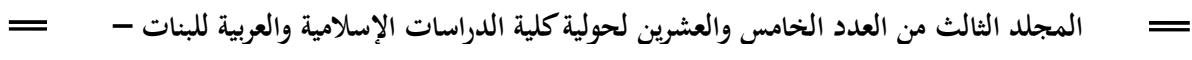

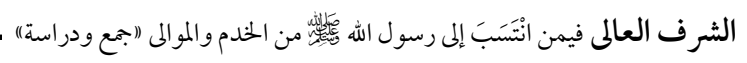

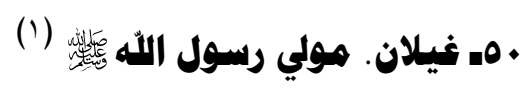
ذكره ابن السكن. وقال روى عنه حديث واله واحد.

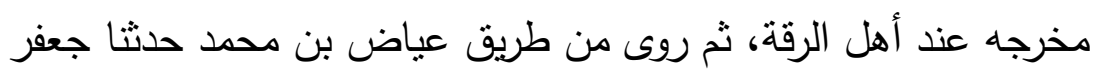

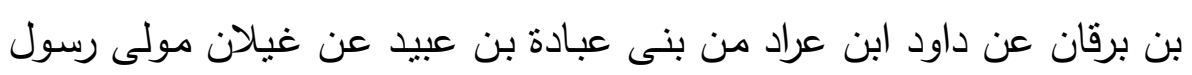
:

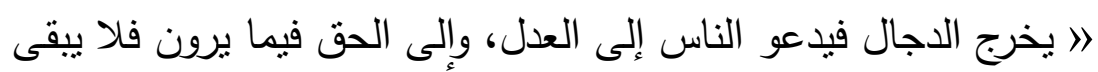

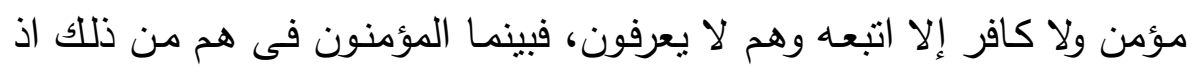

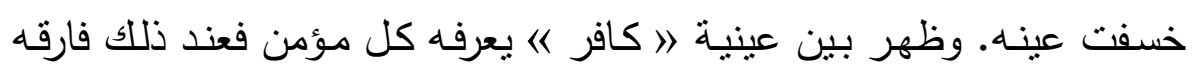
المؤمنون واتبعه الكافرون.

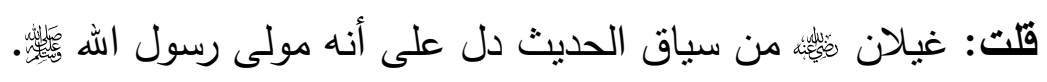

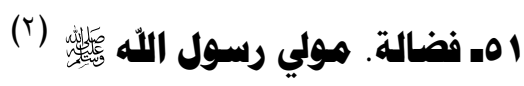

من أهل اليمن نزل بالثشام وأن أبا بكر محمد بن حزم ذكره في موالى

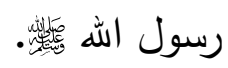
وقال ابن عبد البر فضالة غير منسوب، مذكور فى موالى رسول اله

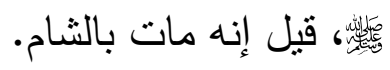

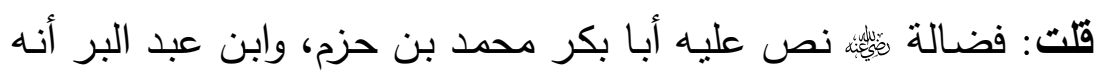

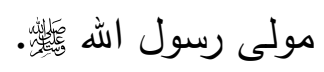

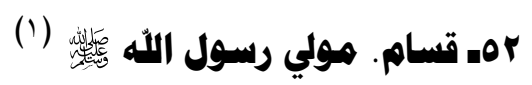

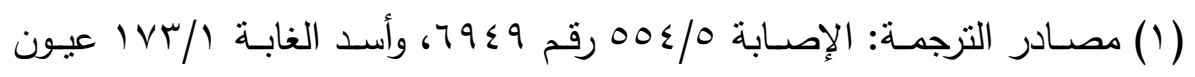

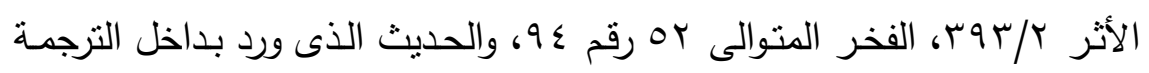

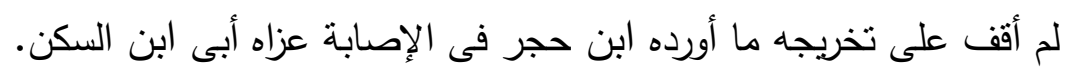

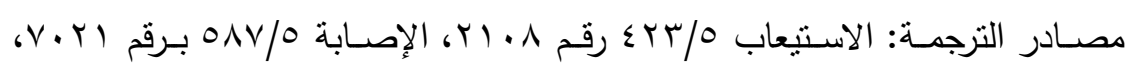

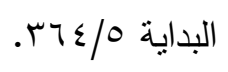

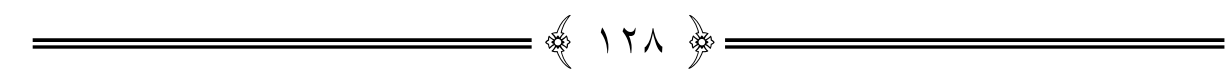




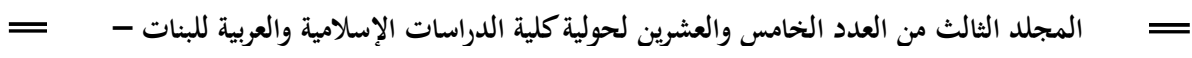

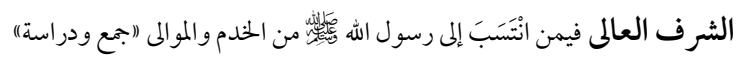

ذكره ابن القيم فى موالى رسول الله

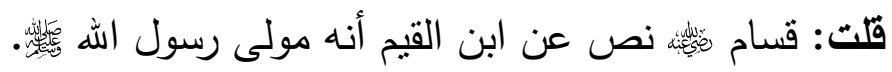

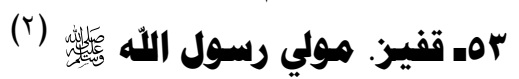

ذكره ابن شـاهين فى الصحابة. وأخرج هو وأبو عوانة فى صحيحه من

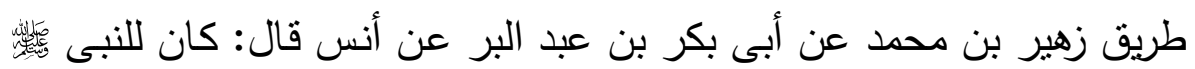

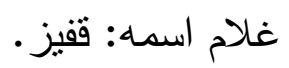

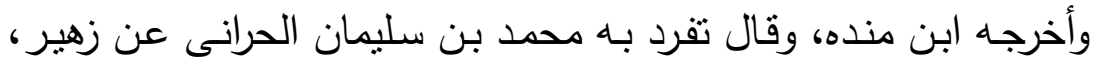

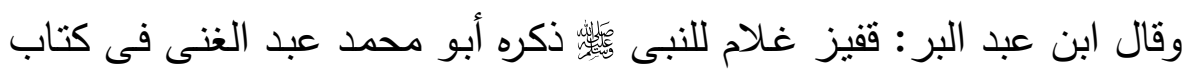

المختلف والموئلف.

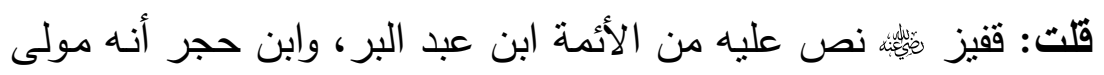

رسول الله

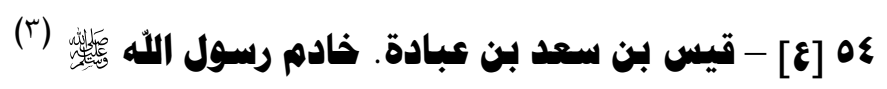

هو قيس بن عبادة بن دُلَّم بن حارثة الأنصارى الخزرجى، أبو عبد الله، وبقال: أبو عبد الملك ويقال أبو الفضل المدنى، أمسه فكيهة بنت عبيد بن دليم

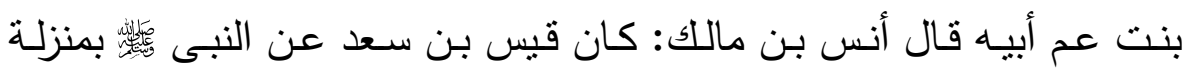
صاحب الثرطة من الأمبر •

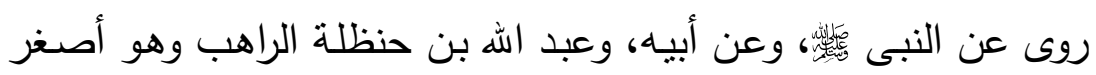

sid

روى عن أنس، وعبد الرحمن بن أبى ليلى وآخرون

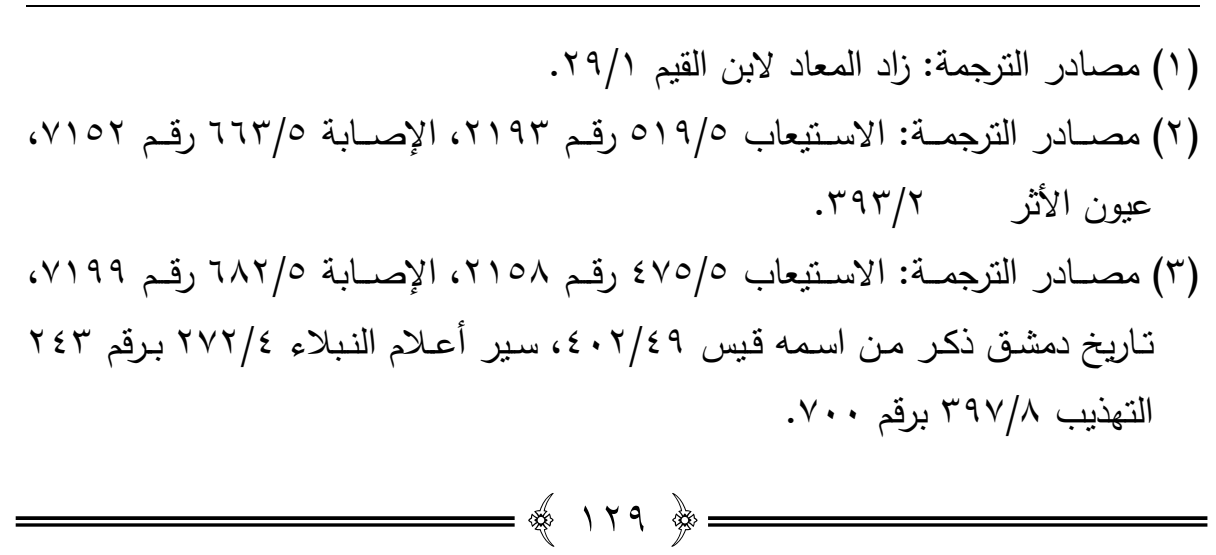




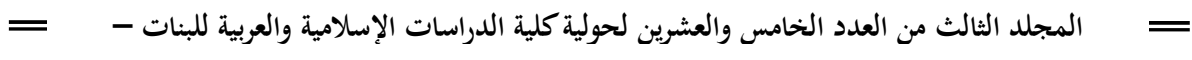

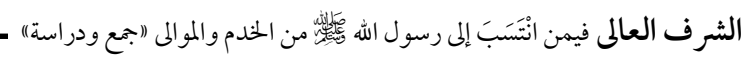

قال أبو نعيم الحافظ: قيس بن سعد بن عبادة بن دليم، خادم رسول الله

ئ

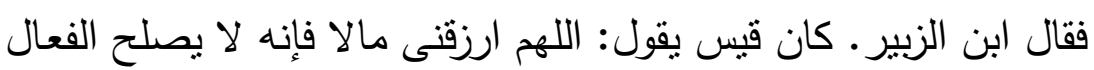
إلا بالمال. وقال الواقدى: كان سخيا كريما داهية.

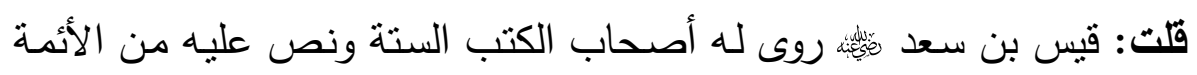

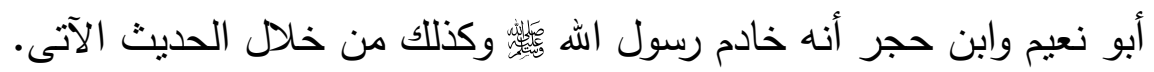

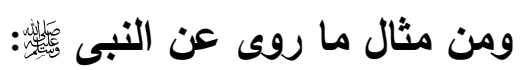
مـا أخرجه الترمذى قال حدثنا محمد بن المثنى أخبرنـا وهب بن جن جرير

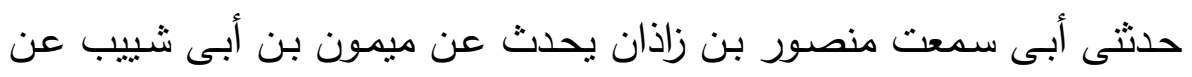

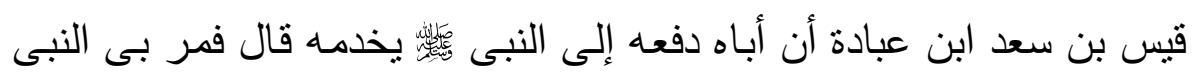

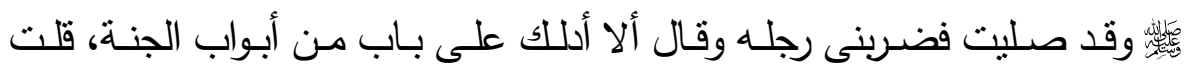

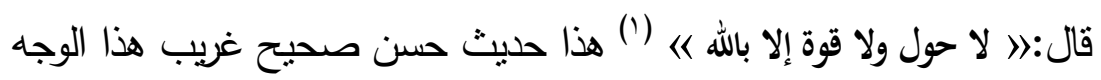

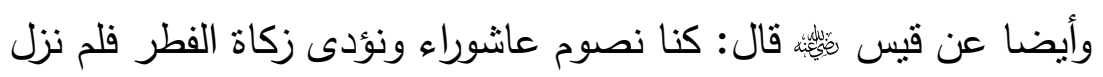

رمضان ونزلت الزكاة لم نؤمر به ولم ننه عنه وكنا نفعله (؟).

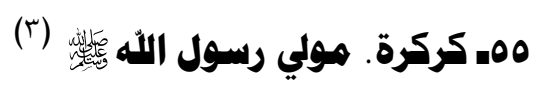
كان نوبيا أهداه له هوذة بن على الحنفى، اليمامى، فأعتقه.

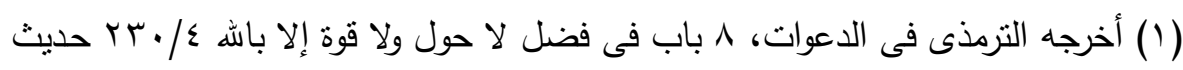
رقم عن قيس بن سعد قئئ.

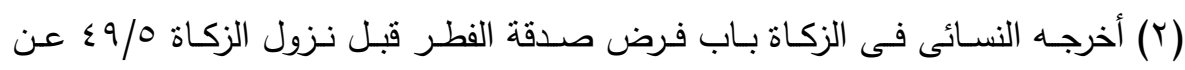
قيس

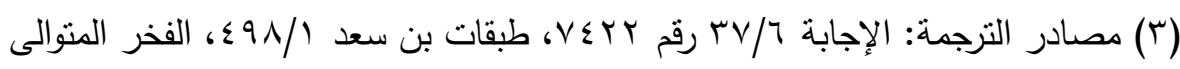

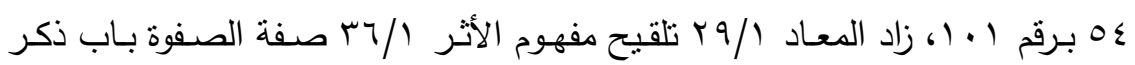
موليات رسول الله

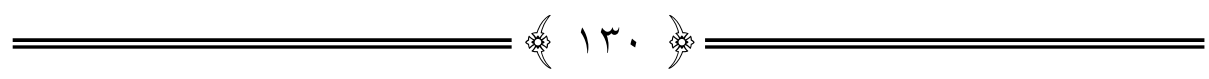




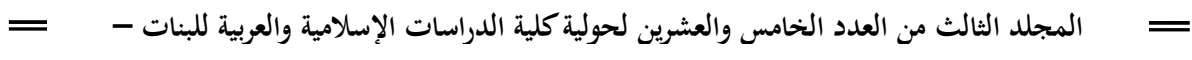

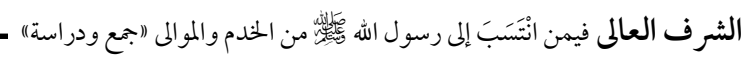

ذكر ذلك أبو سعيد النيسابورى فى شرف المصطفى، وقال ابن منده: لله

$$
\text { صحبة ولا تعرف لله رواية. }
$$

وقال الواقدى: كان يمسك دابـة النبى

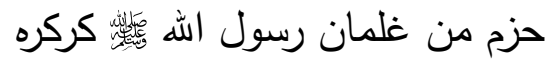

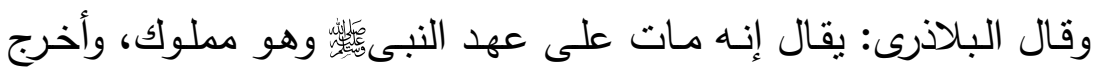
البخارى من حديث عبد الله بن عمرو بن العاص قال: كان على بغلة قال:

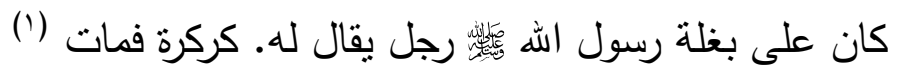

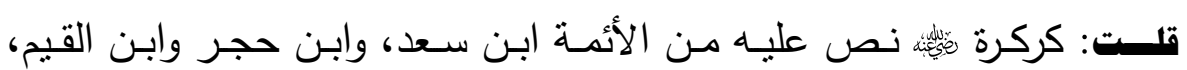

والسخاوى وابن حزم انه مولى رسول الله

(r)

$$
\text { ذكره عبدان المروزى فى الصحابة }
$$

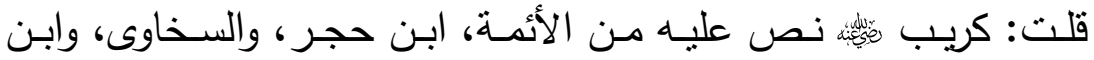

الأثير أنه مولى رسول الله

(r) مـ كيسان. أو ههران هولي رسول الله

ويقال له هرمز ، ويكنى أبا كيسان.

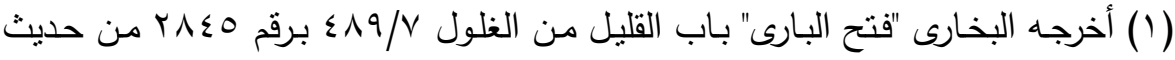

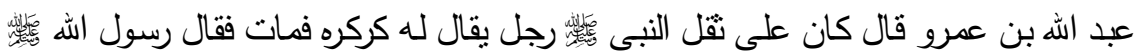
هو فى النار فذهبوا بنظرون إليه فوجدوا عبادة قد غلها، وابن ماجه باب الغلول r / / 90

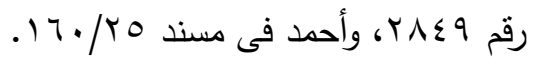

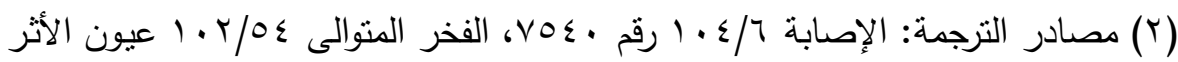

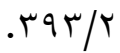

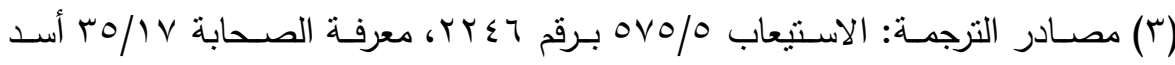

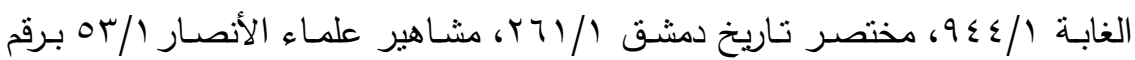




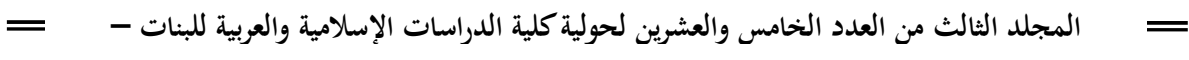

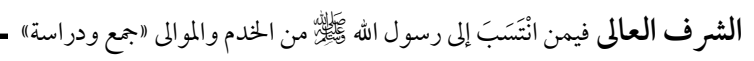

اختلف فيه على عطاء بن السـائب فقيل مهران، وقيل: طهمان، وقبل

ذكوان. كل ذللك فى حديث تحريم الصدقة على آل النبى عنى

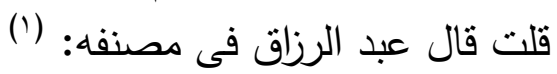

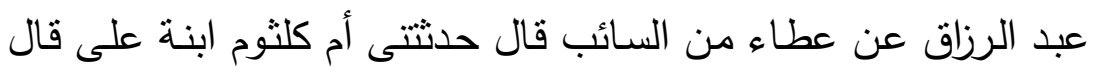

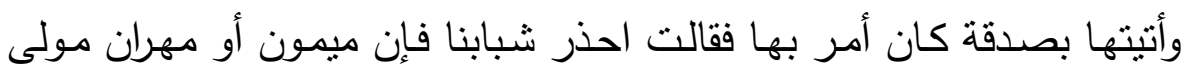
النبى

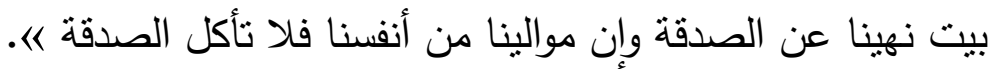

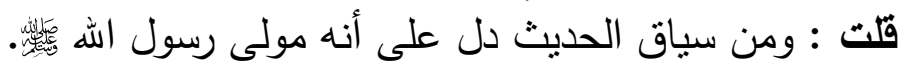

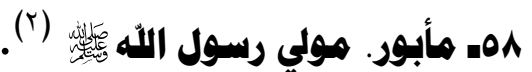

مأبور القبطى، قريب ماريـة القبطية، شيخ كبير لأنـه أخوها، قدم معها

$$
\text { من مصر عن مصعب الزبيرى. }
$$

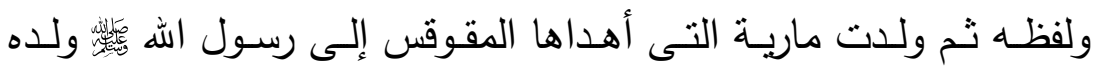

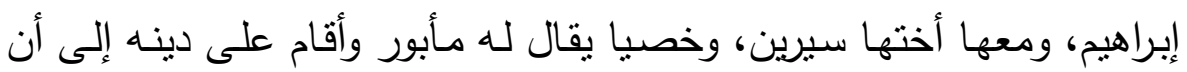

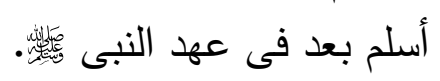

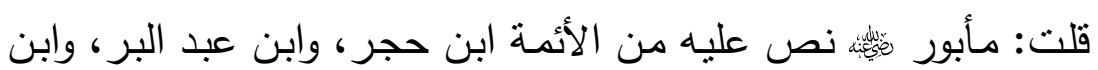

الأثير ، وابن القيم أنه مولى رسول الهه ماله

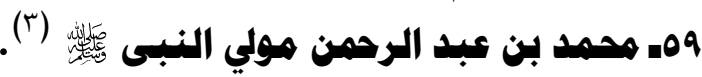

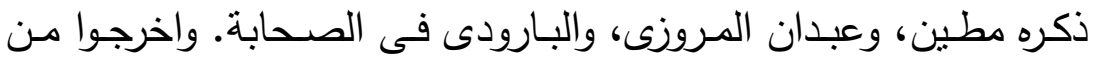

طريق يحيى بن أيوب عن عبيد الله ابن أبى جعفر عن صفوان ابن سليم عن البردي

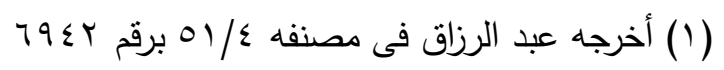

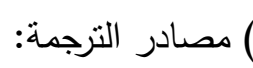

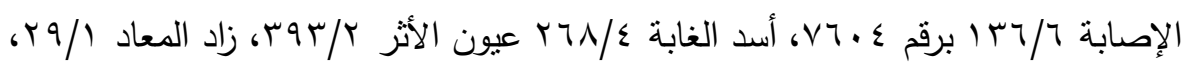

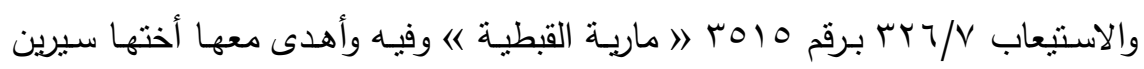

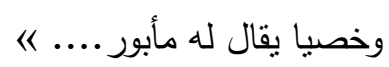

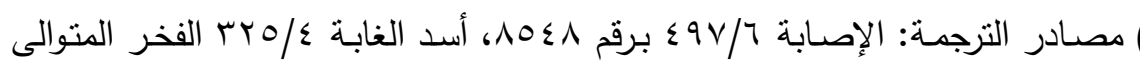

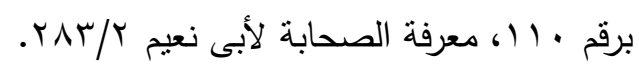

$=$ ITr 


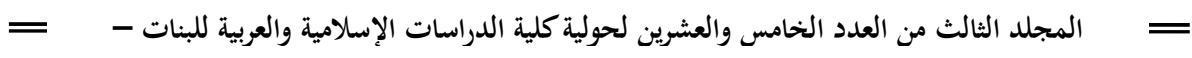

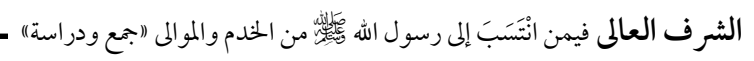

عبد البر بن يزيد بن أبى جعفر عن محمد بن عبد الرحمن مولى رسول الله

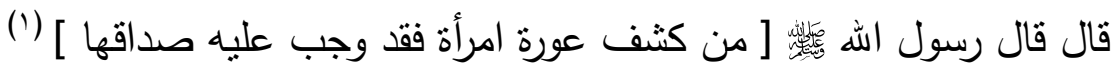

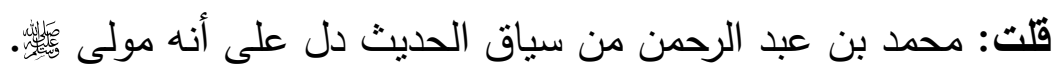

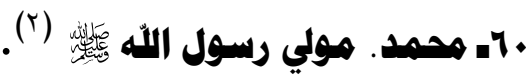

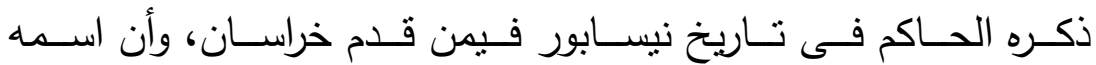

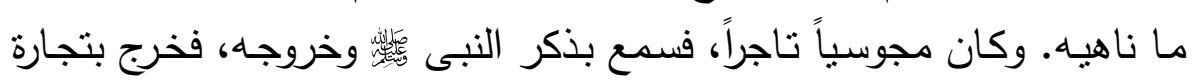

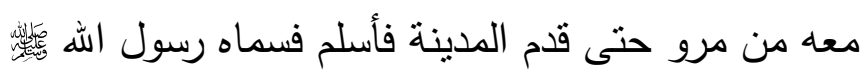

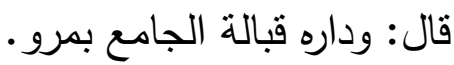

وأورده أبو موسى وداره فباره فيالة الجامع بمرو •

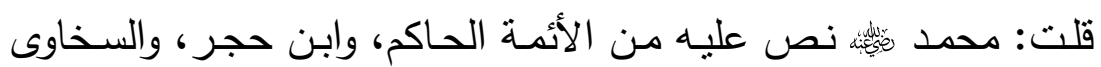

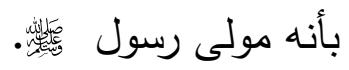

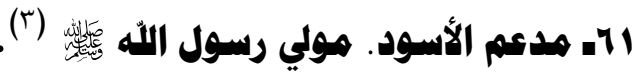

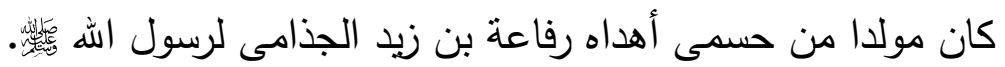

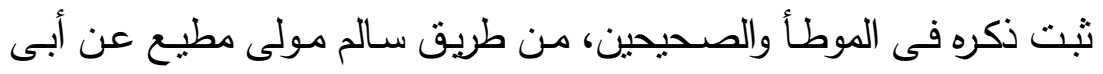

هريرة فى فتح خيبر فذكر الحديث وفيه (أن مدعما أصابه غائر فقتله)(؛).

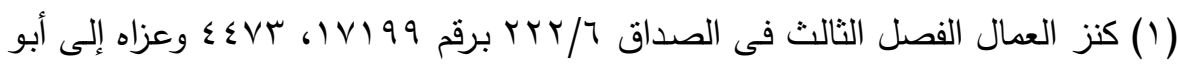

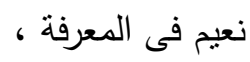

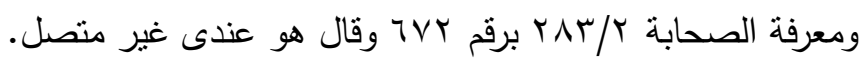

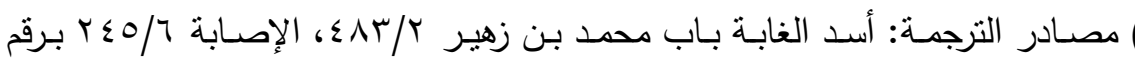



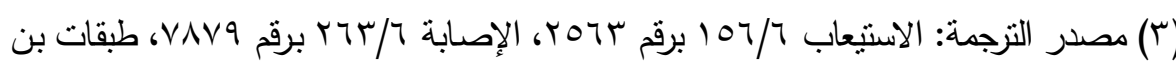

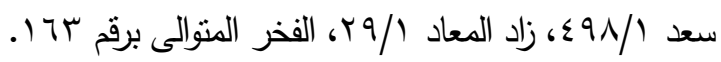

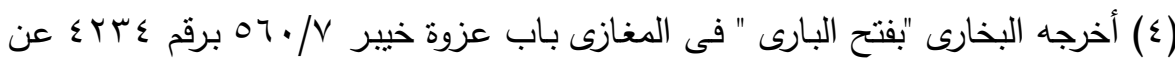

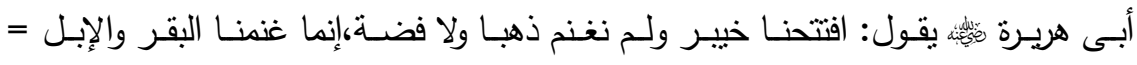

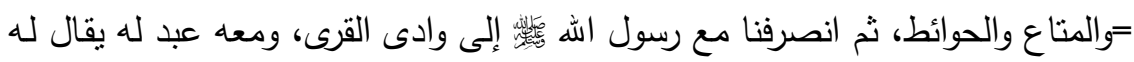

$\overline{=}$ 


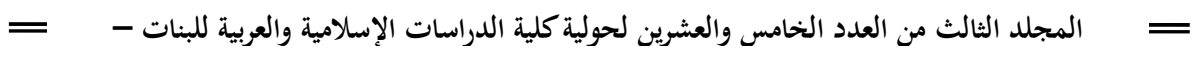

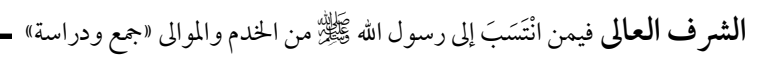

$$
\text { ويقال: إنما أهداه فروة بن عمرو الجزامى. }
$$

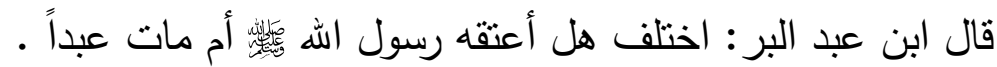

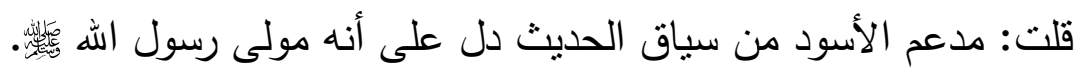

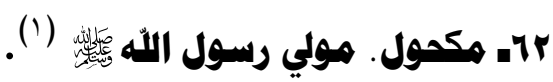

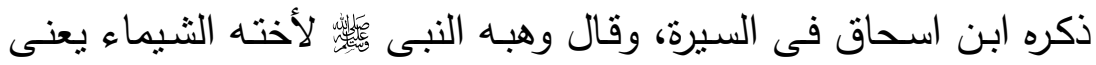

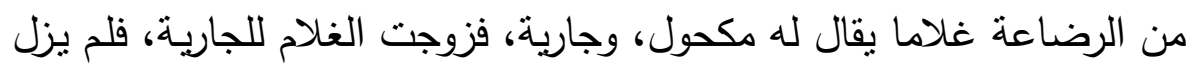
من نسلهم بقية والله أعلم.

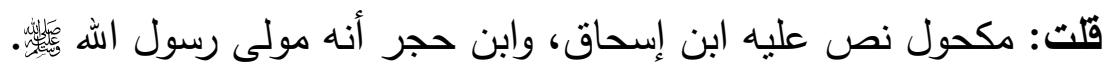

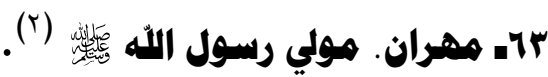

قال الثورى عن عطاء بن السائب قال: أتيث أم كلثوم بنت على الثـئ

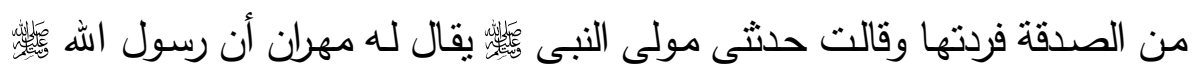

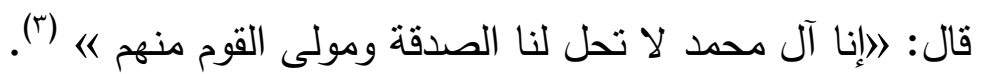
وقال البخارى عن أبى نعيم عن سفيان. يقال له مهران أو ميمون.

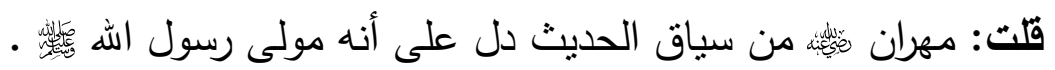

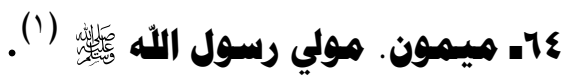

مدعم أهداه له أحد بنى الضباب فبينما هو يحط رجل رسول الله فئس إذ جاءه سهم غائر

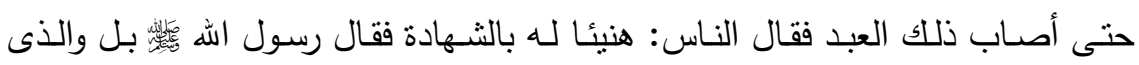
نفسى بيده إن الثملة التى أصابها يوم خيبر من المغانم لم تصبها المقاسم لتتتعل عليه

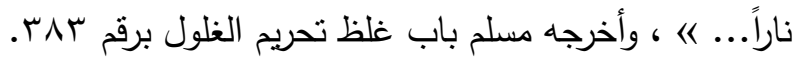

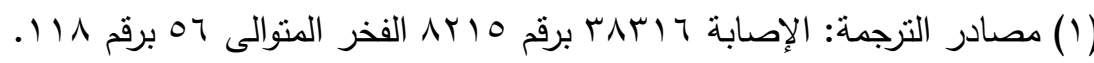

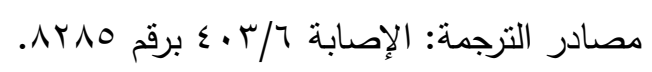

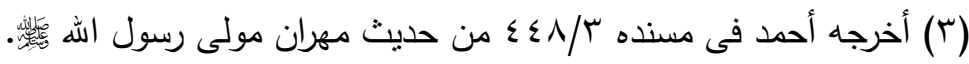




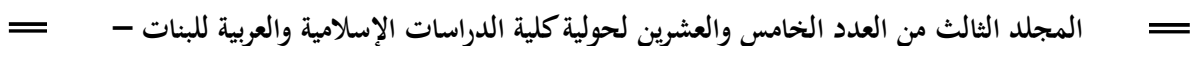

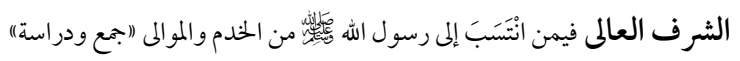

قال ابن حجر : تقدم فى مهران

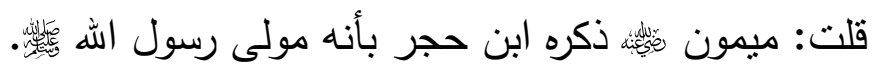

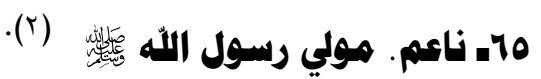
ذكره العسكرى فى الصحابة، وقال: لا أعلم لله حديثا مسنداً وأخرج من

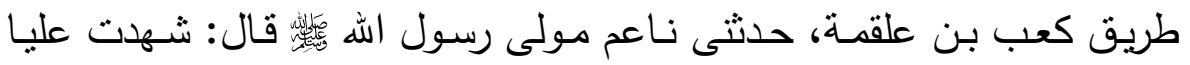
خطب على بعير فتقدم، ثم نزل فدعا بكبش أقرن فذبحه فقال: هذا عن على وآل على.

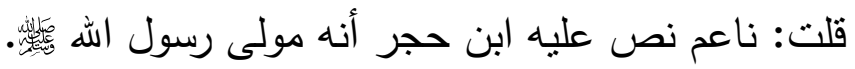

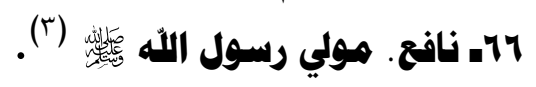

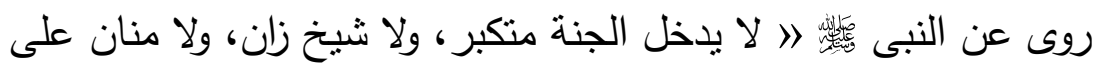

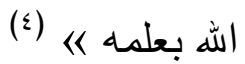

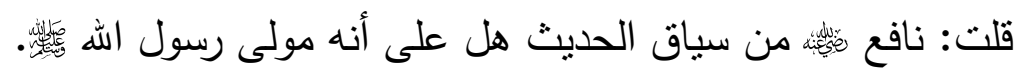

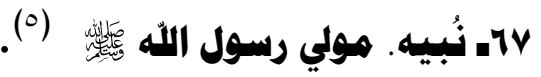
قال ابن عبد البر • لا أعرفه بأكثر من أن بعضهم ذكره فى موالى النبى

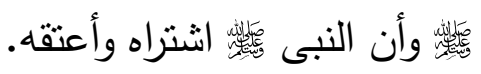

$$
\begin{aligned}
& \text { مصادر الترجمة: الإصابة ؟// (اء برقم } 9 \text {. بر. }
\end{aligned}
$$

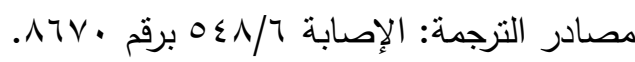

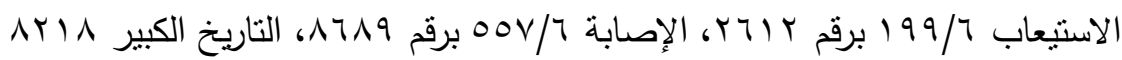

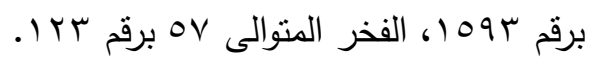

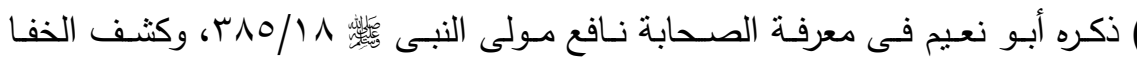

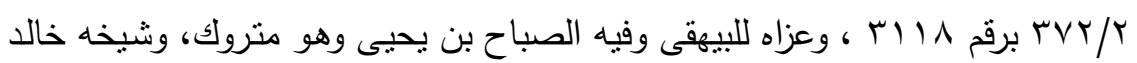

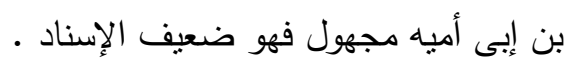

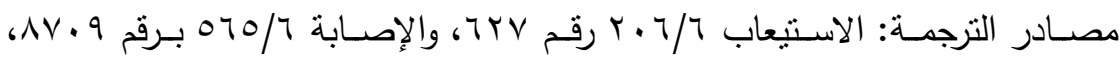

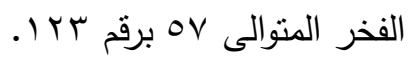




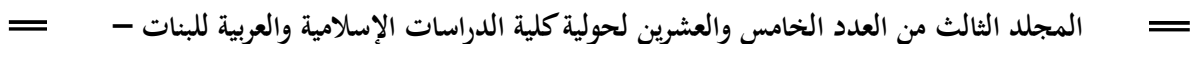

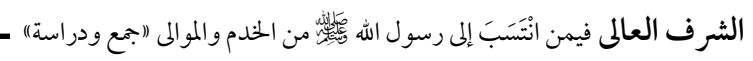

وقد قيل فى نبيه هذا مولى النبى

كان من مولدى السراة.

واختلط فى ضبطه: فقيل بالتصغير ، وقيل بوزن عظيه.

قلت: نُبيه

رسول الله

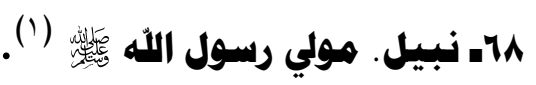

قلت: ذكره ابن سيد الناس، والسخاوى أنه مولى رسول الله ئسئ.

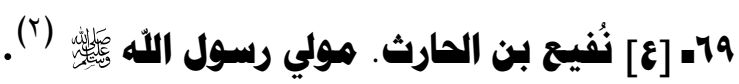

هو : نفيع بن الحارث بن كلدة بفتحتين ابن عمرو الثقفى أبو بكرة

يقال: ابن مسروح، وهو ممن غلبت بن عليه كنيته.

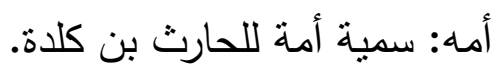

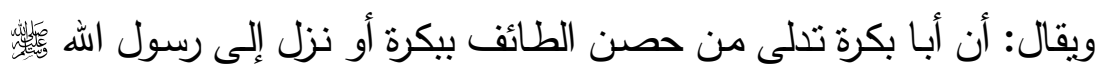
فمكناه رسول الله

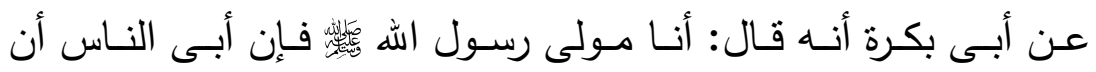
ينسبونى فأنا نفيع بن مسروح.

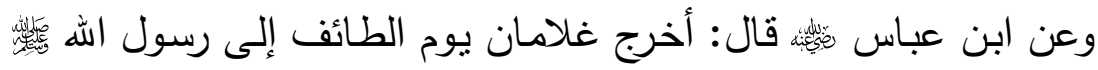
فاعتقها أحدهما أبو بكرة فكانا من مواليه.

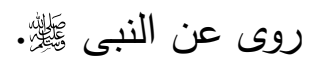
وعنه: أولاده عبد الله، وعبد الرحمن، وعبد العزبز ، وآخرون سكن البصرة وأنجب أولادا لهم شهرة.

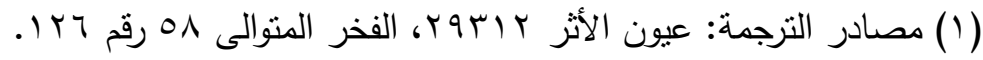

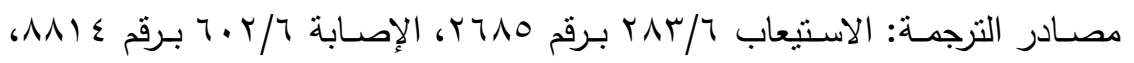

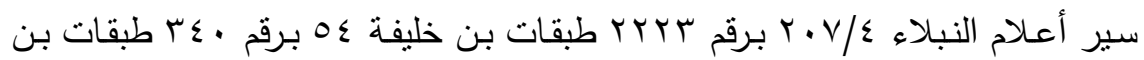




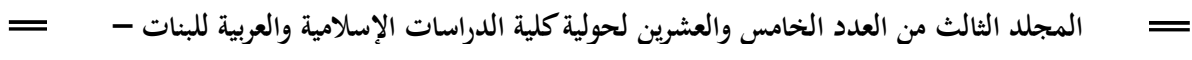

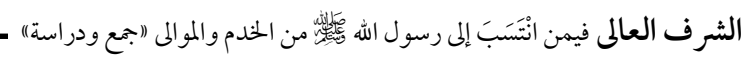

قـال ابن سـد: مـات فى خلافهـ معاويـة بـن أبى سفيان بالبصـرة. سـنة

إحدى وخمسين

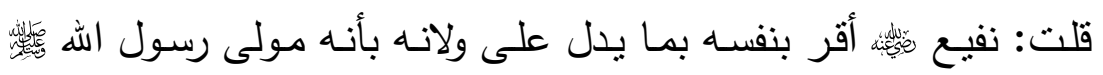

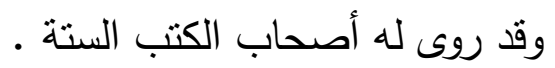

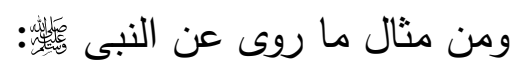

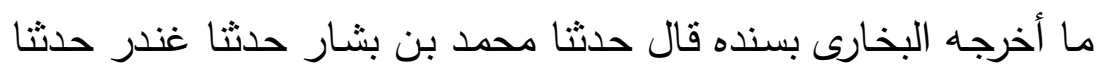

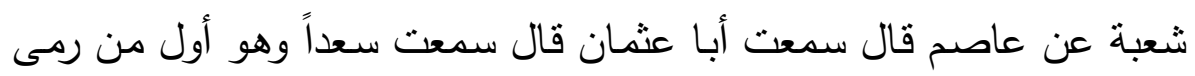
بسهم فى سبيل الله وأبا بكرة وكان تسور حصن الطائف فى أناس فجاء إلى إلى ألى النبى لئس

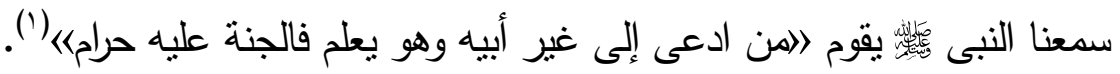

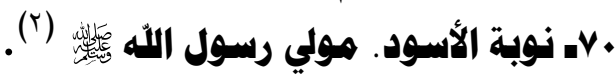

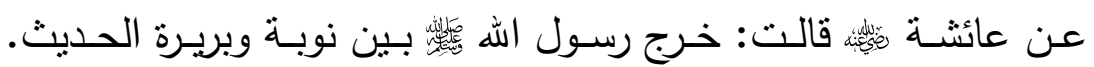

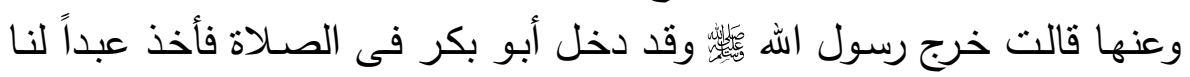
أسود يقول له: نوبة، وبريرة يهاديانه بينهما

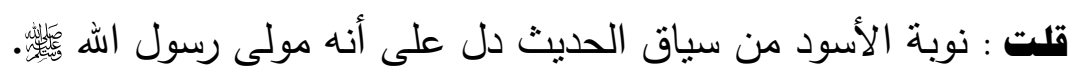

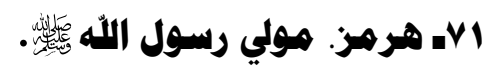

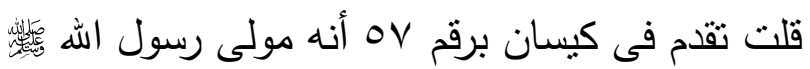

(r) روى حديثه الطبرى، ومطين، وابن منده وغيرهم من طريق الثورى عن

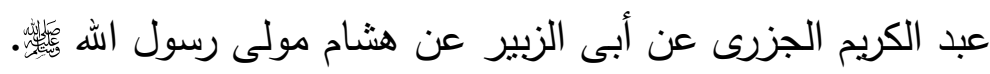
( (1) أخرجه البخارى " بفتح البارى " فى المغازى باب غزوة الطائف سنة ثمان Y Y Y برقم דצY

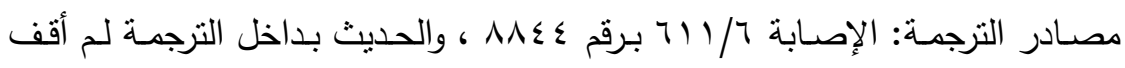

$$
\text { على تخريجه. }
$$

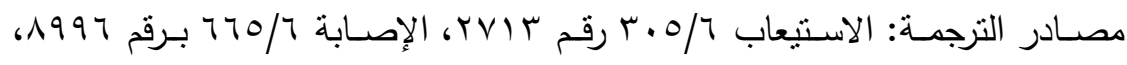

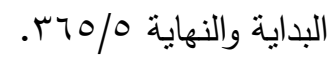




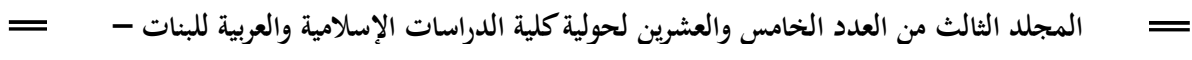

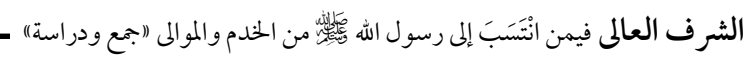

قال جاء رجل إلى النبى

مس قال طلقها... « (1)

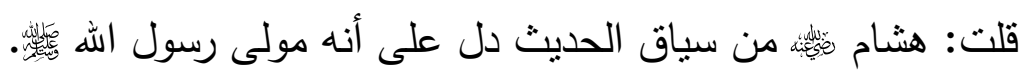

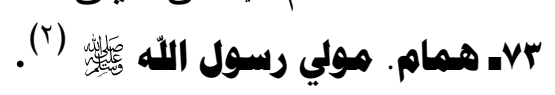

أخرج أبو موسى من طريق جعفر المستغفرى عن البردعى أن أبا الزبير

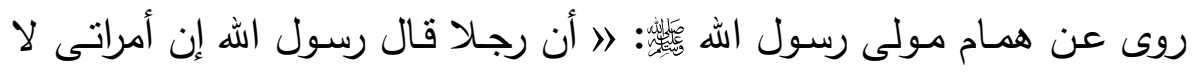

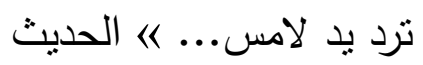

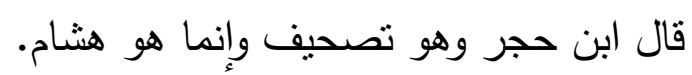

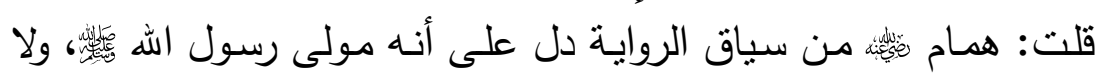

مانع أن يكون الحديث روى مرة عن طريق هشام، ومرة عن طريق همام.

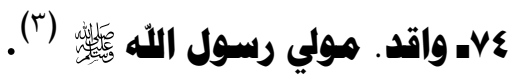

ذكره الحسن بن سفيان في مسنده، والطبرانى في معجمهـه وأخرجا من

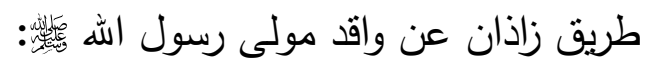

[ من أطاع الله فقد ذكر الله وإن قلت صلاته وصول اله وصيامه..... ] (؛).

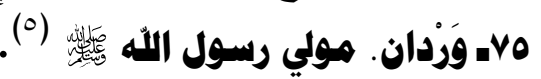
ذكره أبو نعيم فى الصحابة.

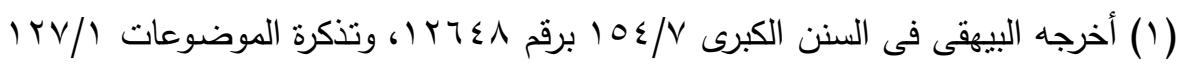

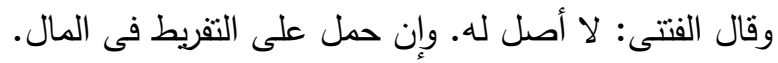

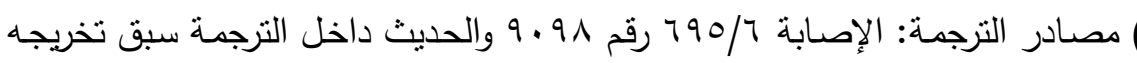

$$
\text { فى ترجمة رقم Y V ولا أصل لها له. }
$$

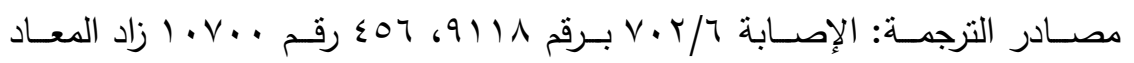

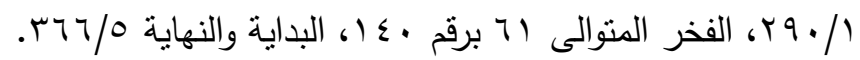

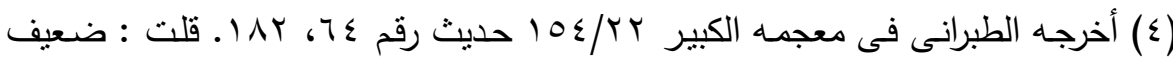

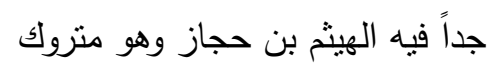

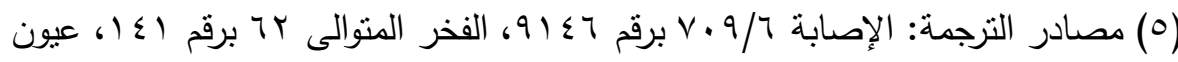
الأثر / 


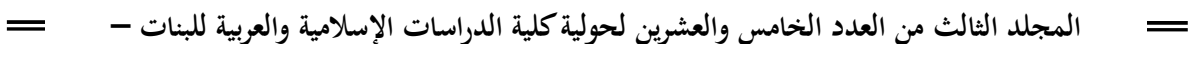

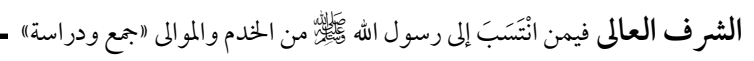

وأخرج من طريق الحسن بن عمارة عن الأصبهانى عن عكرمة عن ابن

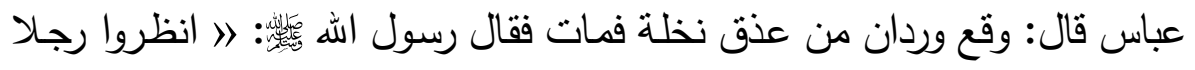

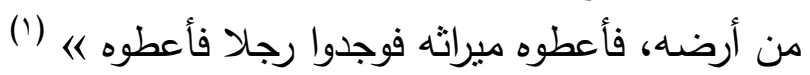

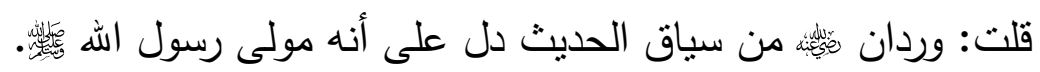

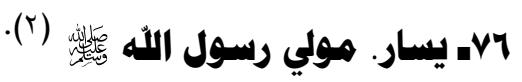

قيل: كان نوبيا. وهو الراعى الذى قتله العرنيون الذين استاقوا ذود رسول

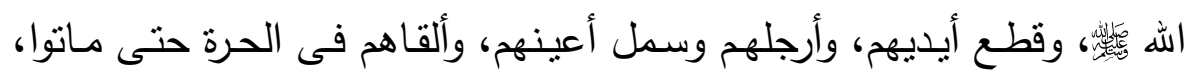

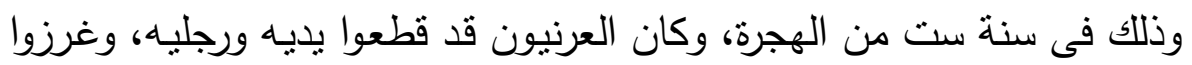
الشوك فى لسانه وعينيه حتى مات. وأدخل المدينة ميتاً وهربوا بالسرح فَأُدركوا وفعل بهم. عن سلمة من طريق الطبرانى قال: كان للنبى ولئي

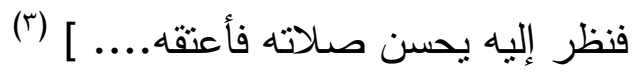

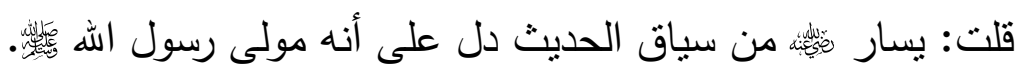

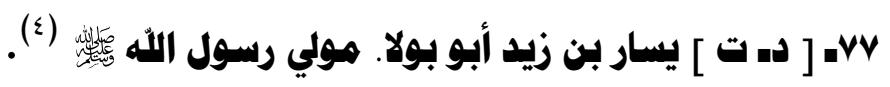

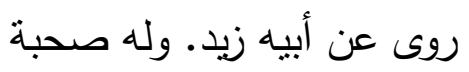

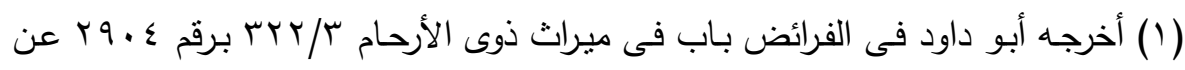

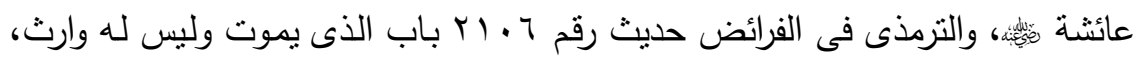

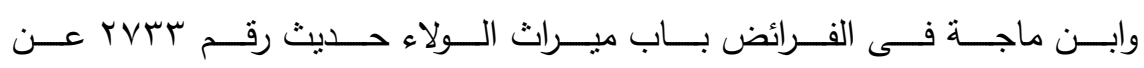

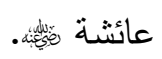

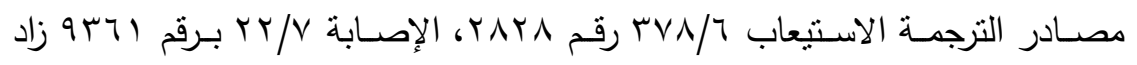

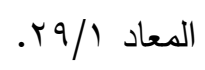

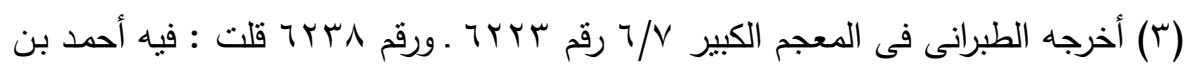

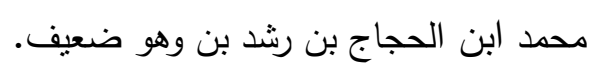

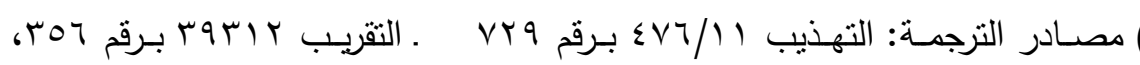

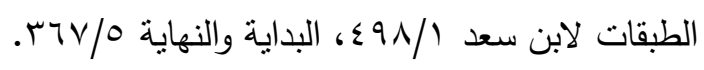




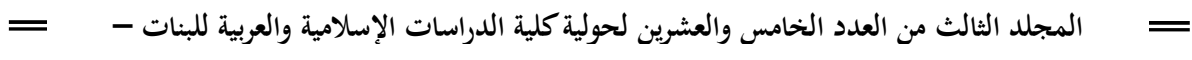

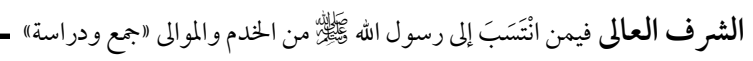

وعنه ابنه : بلال ذكره ابن حبان فى التقات.

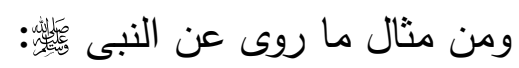

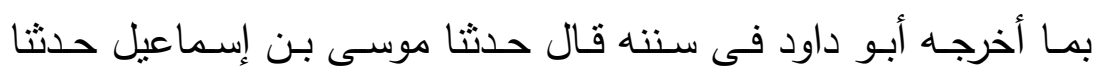

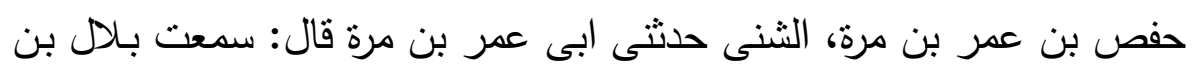

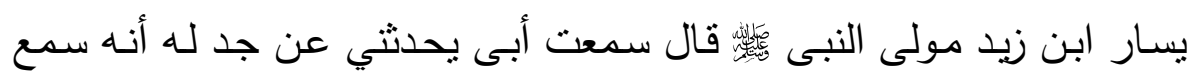
رسول الهة

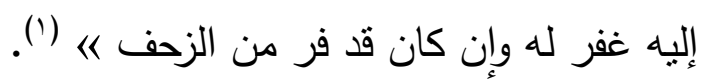

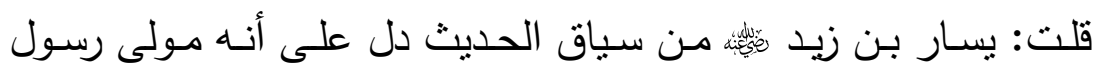
الله 0

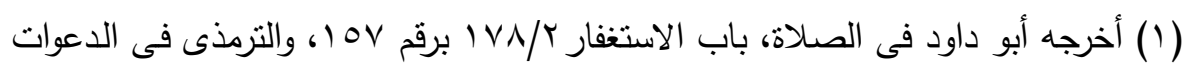

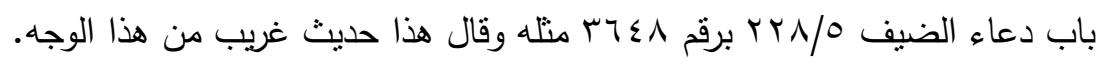

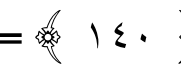




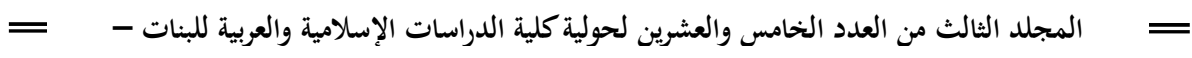

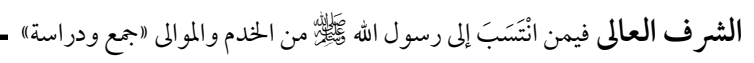

\section{المبحث الثانى}

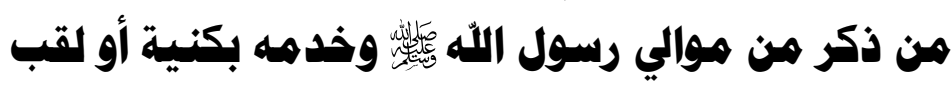

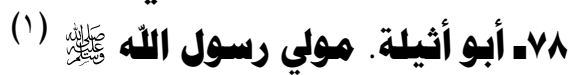

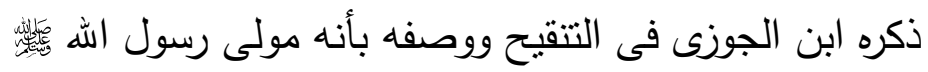

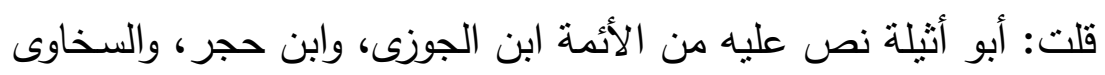
بأنه مولى رسول الله فئل

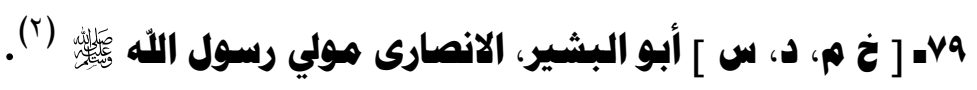

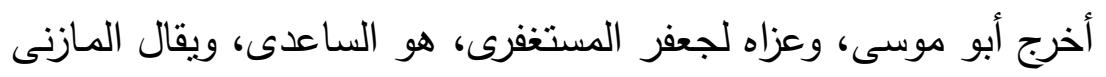

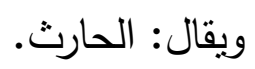

قال: ابن حجر فى التهذيب: ذكره ابن عبد البر عن الواقدى: أبو بشير من موالى النبى عبيد شهر الخندق وما بعدها ويقال جاوز المائة.

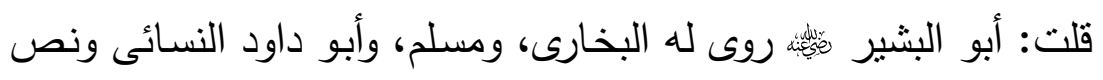

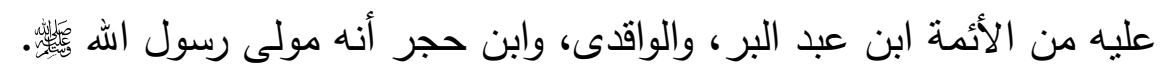

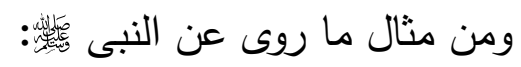

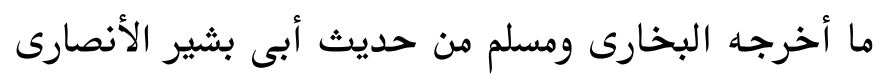

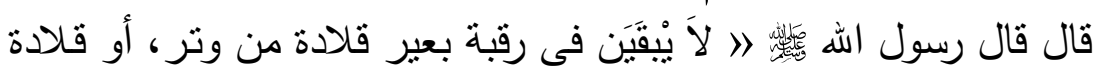

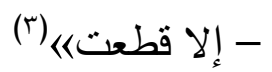

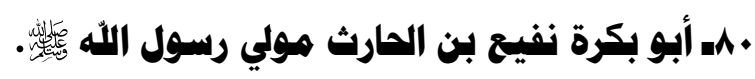

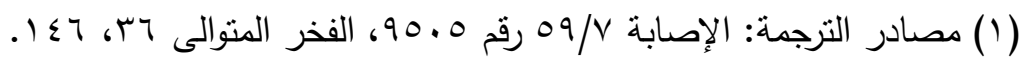

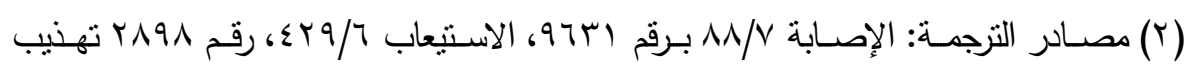

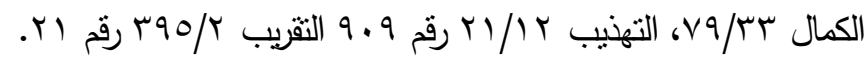

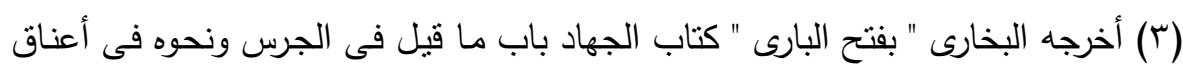

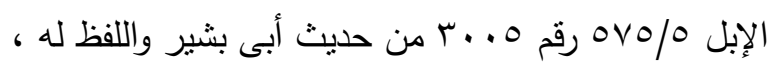

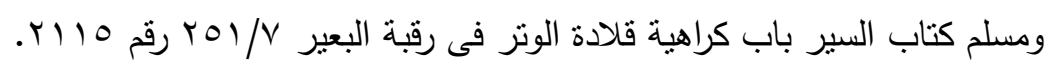

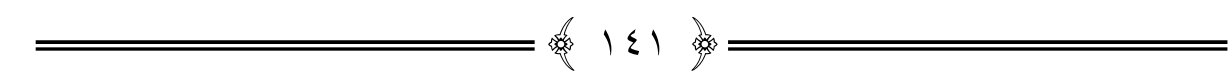




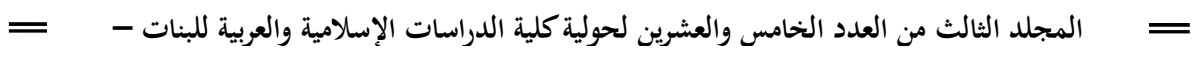

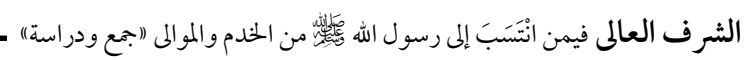

سبق ترجمته برقم 97 بأنه مولى رسول الله

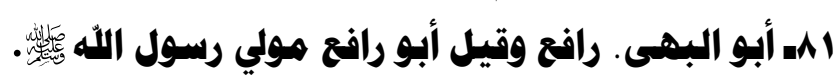

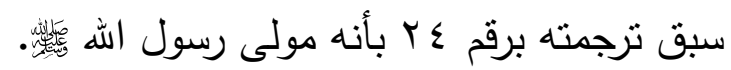

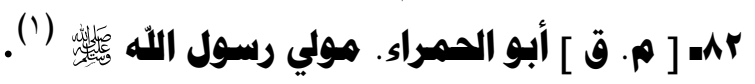

قال ابن عبد البر : قيل اسمه هـلال بن الحارث ويقال هـله بن ظفر

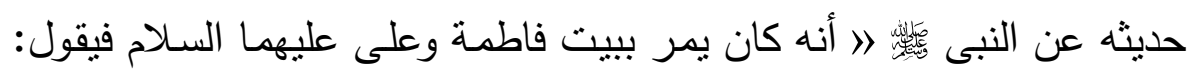

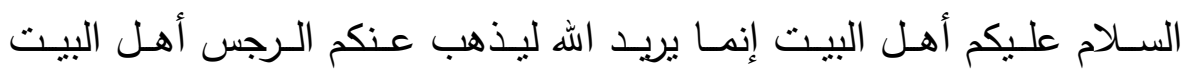
ويطهركم تطهيرا ll.

روى عن النبى لئليّة، وعنه: أبو داود الأعمى، وسعيد بن جبير من طريق ضعيف قال البخارى: يقال له صحبه وحديثه لا يصح نزل حمص.

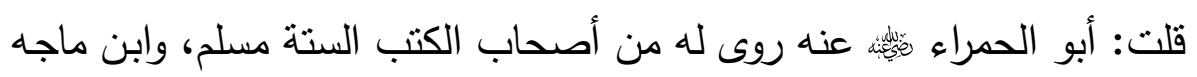

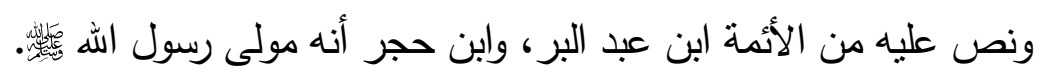

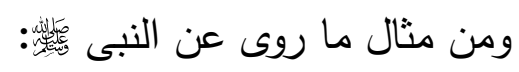

بما أخرجه ابن ماجة قال حدثنا أبو بكر بن أبى شيبة ثنا أبو نعيم ثنا يونس بن أبى اسحاق عن أبى إسحاق عن داود عن أبى الحمراء قال رأبت

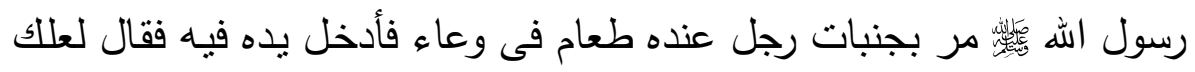

غششت من غشنا فليس منا ای(r)

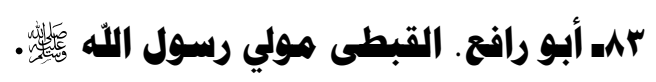

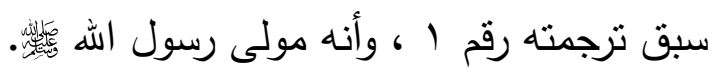

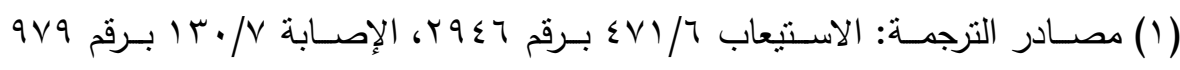

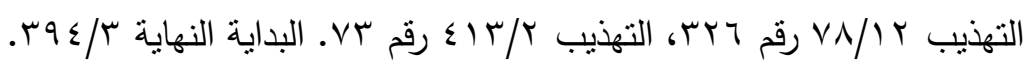

(Y) أخرجه ابن ماجة فى البيوع باب النهى عن الغش r آجr رقم ، بrr عن أبى الحمراء 


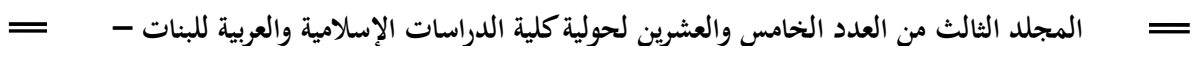

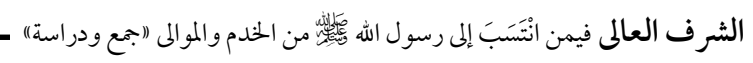

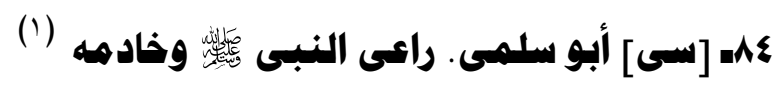

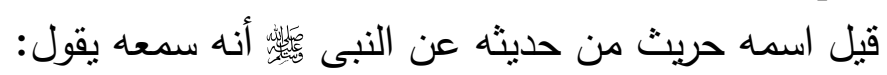

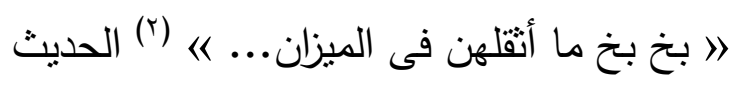

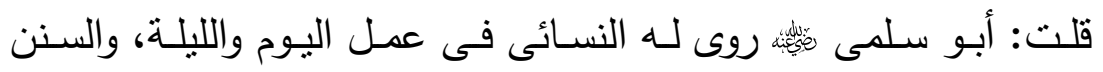

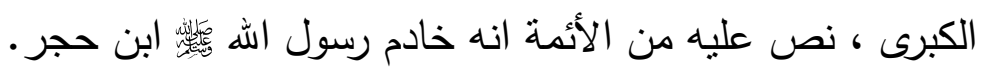

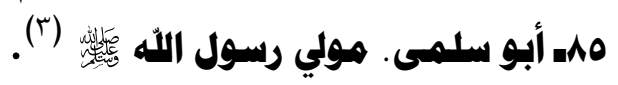

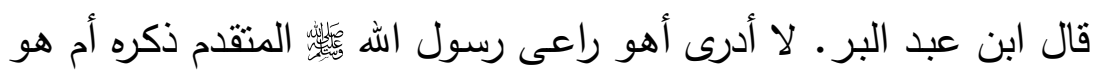
غيره. قلت: أبو سلمى ذكره من الأئعة ابن عبد البر أنه مولى رسول اله على الثك.

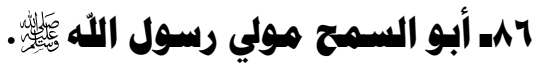

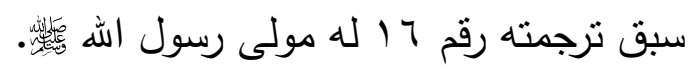

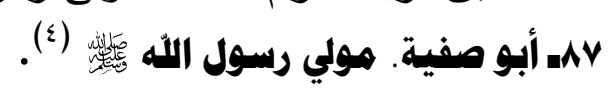
قال البخارى. عداده فى المهاجرين.

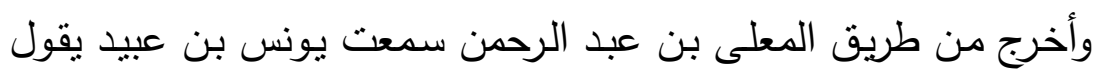

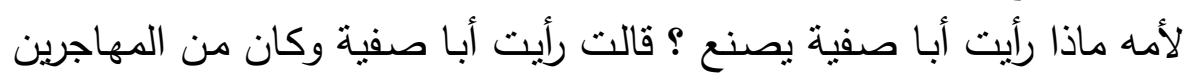

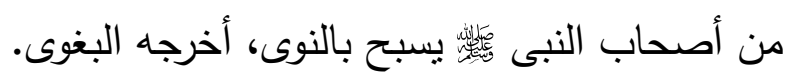

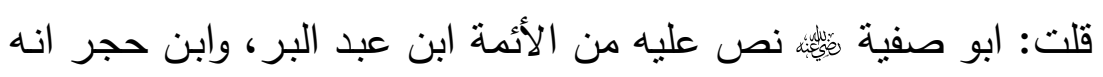
مولى رسول الله

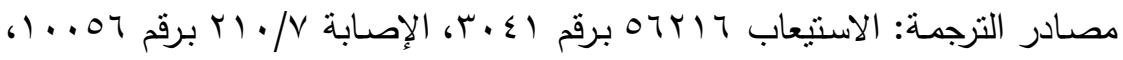

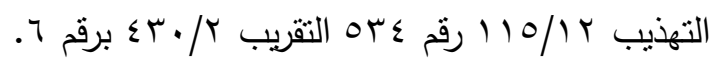

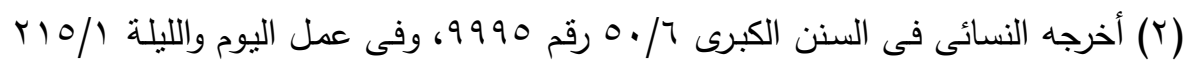
رقم 178

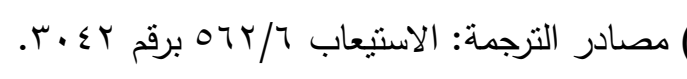

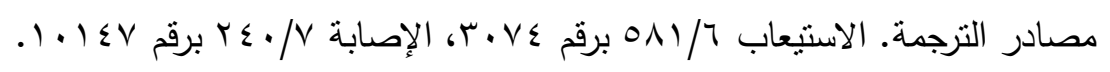




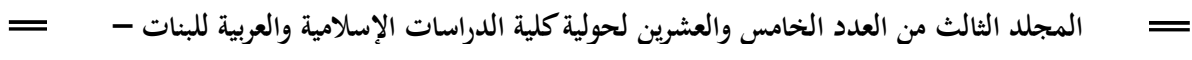

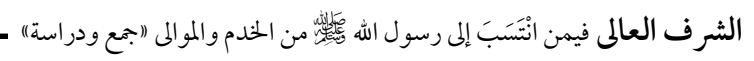

\section{يهـ ابو ضميرة. هولي رسول الله أله}

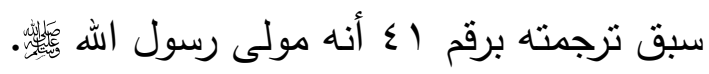

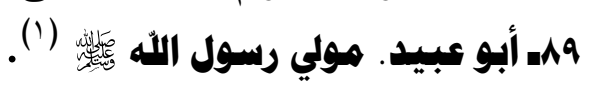

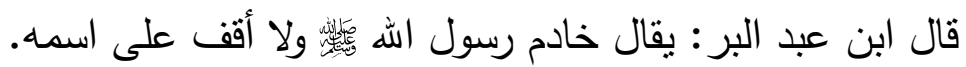

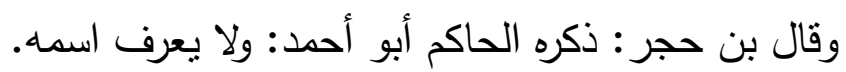

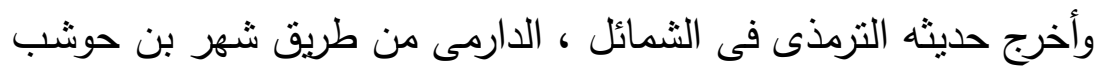

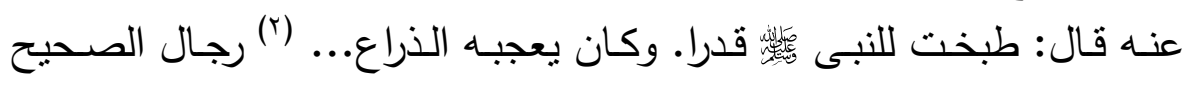

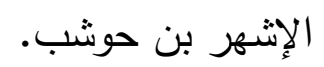

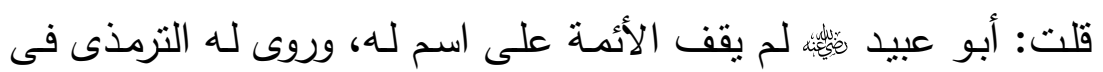

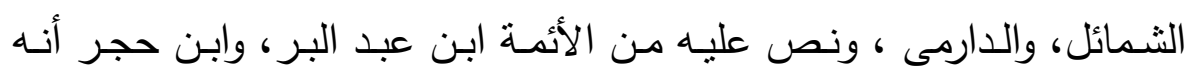
مولى رسول اله له

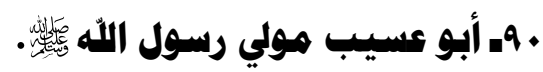
سبق ترجمته برقم ب أنه مولى رسول الله فوله

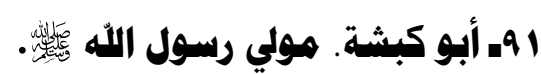

سبق ترجمته برقم 10 بأنه مولى رسول الله

raـ أبو كندير. هولي رسول الاله بَ سبق ترجمته برقم سم بأنه مولى رسول الهوله

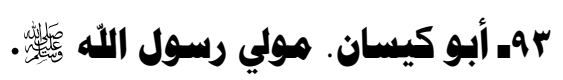
سبق ترجمته برقم OV بأنه مولى رسول الله

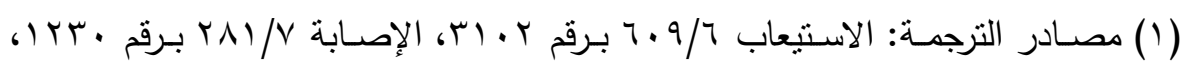

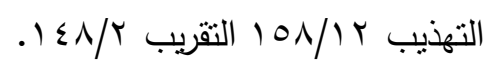

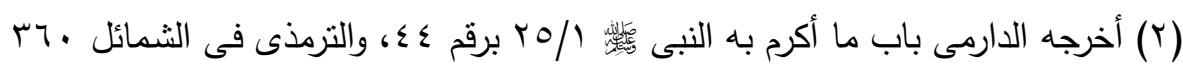
برقم 19. 


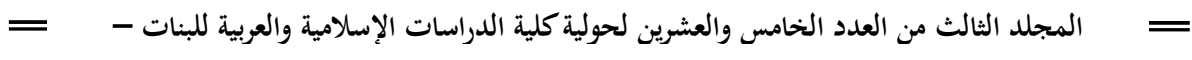

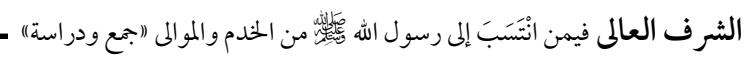

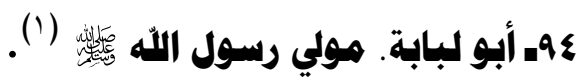
ذكره محمد بن حبيب فى كتابه المحبر .

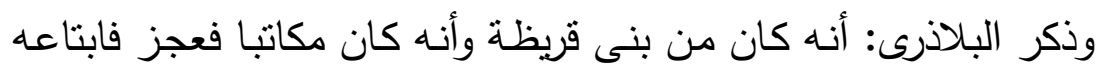
رسول الله

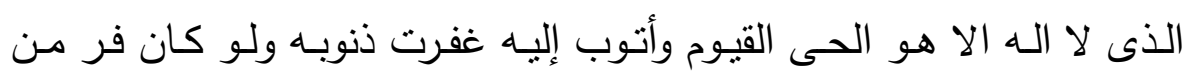

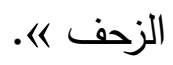

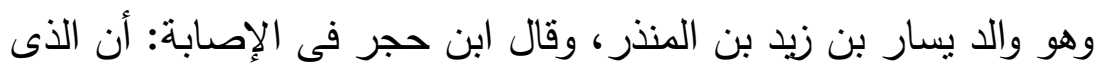

روى الحديث المذكور هو زيد بن مولا.

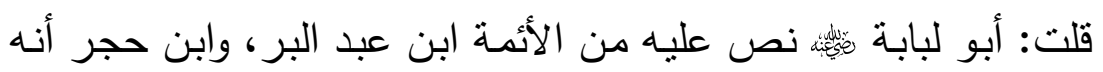

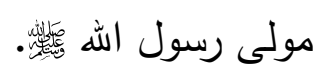

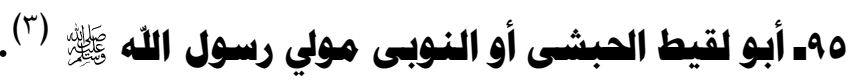

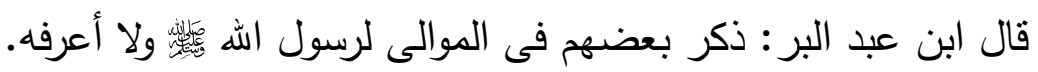

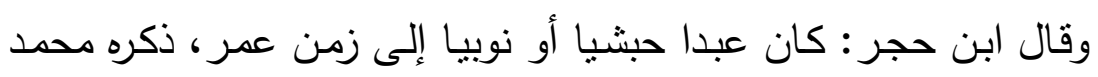

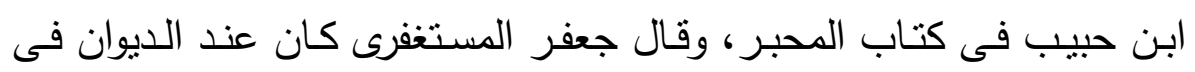
خلافه عمر

قلت: أبو لقيط الحبشى نص عليه من الأئدة ابن عبد البر، وابن حجر

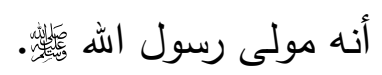

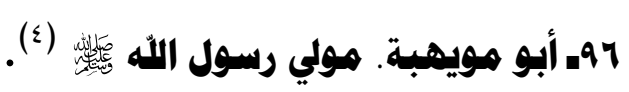

ويقال: أبو موهبة، وأبو موهوبة وهو قول مول الواقدى: مولى رسول اله له

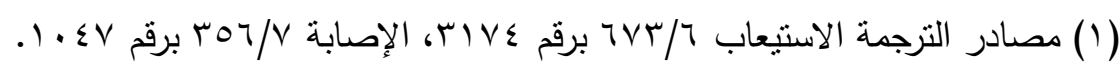

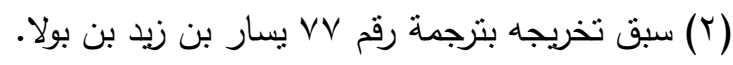

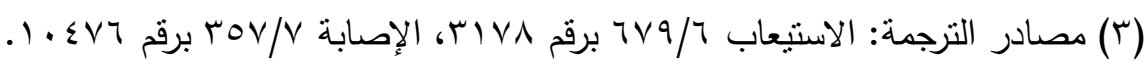

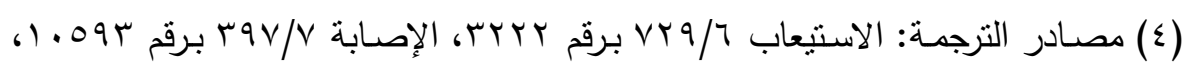

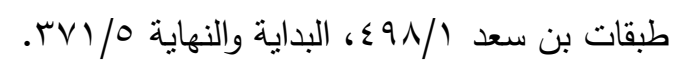




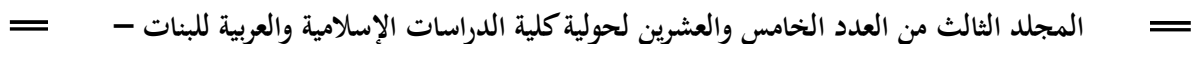

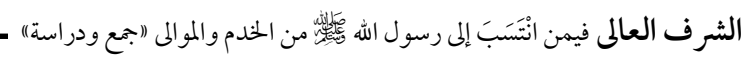

قال البلاذرى: كان من مولدى مزينـة وشـهـ غزوة المريسع وكان ممن يقود لعائشة جملها.

روى عنه: عبد الله بن عمرو بن العاص وهو من أقرانه، أخرج حديثه

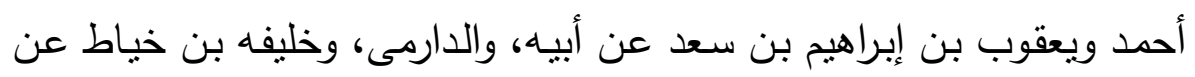

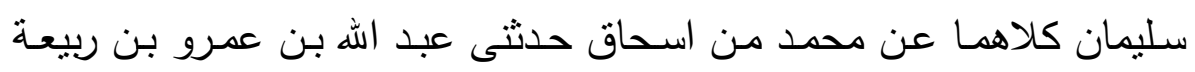

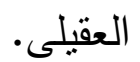

وفى رواية الدارمى حدثنا عبد الله بن عمرو بن العاص عن أبى مويهبة

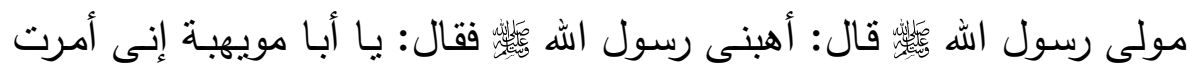
أن استغفر لأهل البقيع... « (").

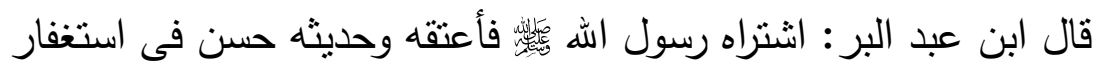

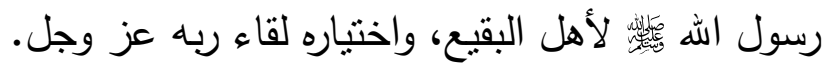

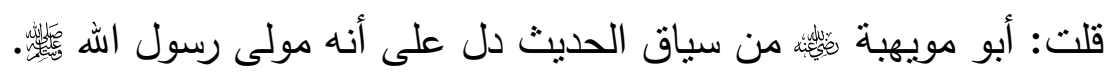

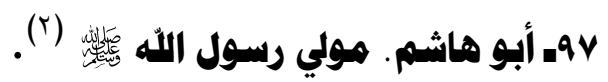

قال: ابن حجر : تابعى أرسل حديثا.

فذكره: أبو موسى فى الذيل على المعرفة، فأخرج من طريق أبى نعيم

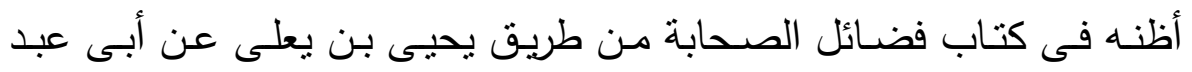

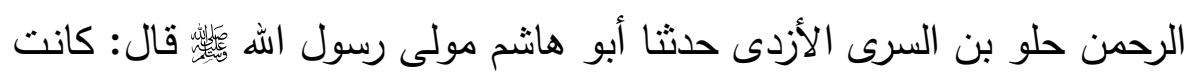

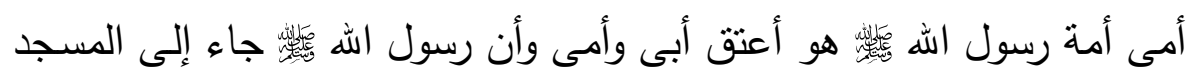
فوجد عليا وفاطمة مضطجعين قد غشيتهما. الثمس فقام عند رؤوسهما وعليه كساء خيبرى فمده دونهم قال: أحب بادر حاضر ، ثناء خدم مرات (r).

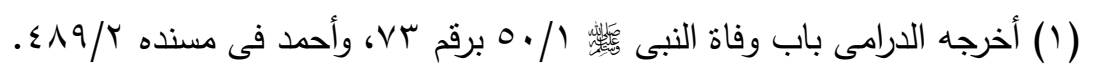

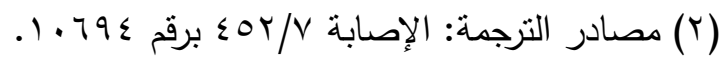

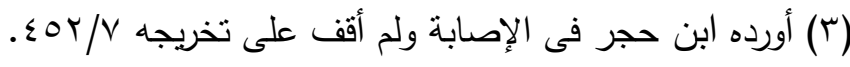




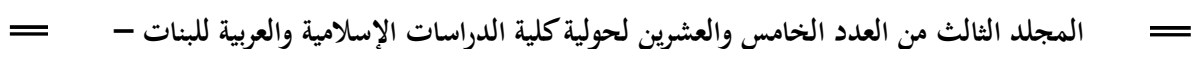

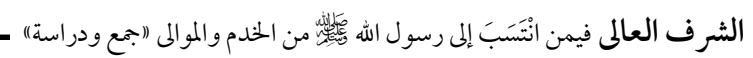

قال: ابن حجر فعلى هذا فالحديث لوالد أبى هاشم، ومن طريق عبد الله

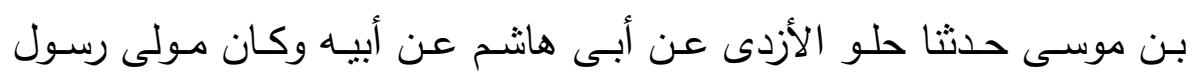
الله

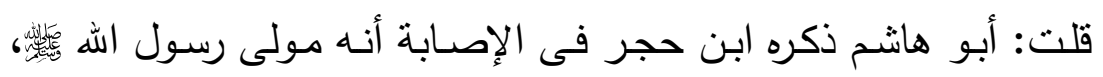

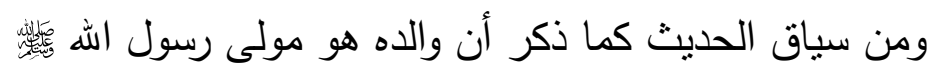

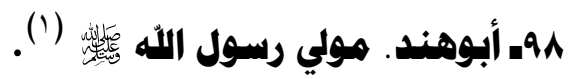

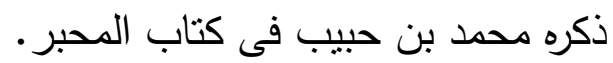

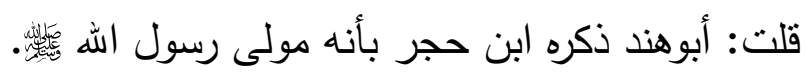

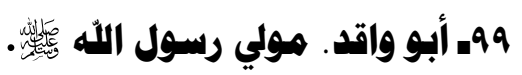

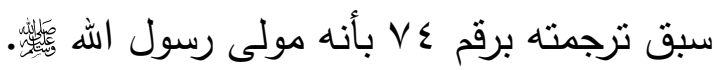

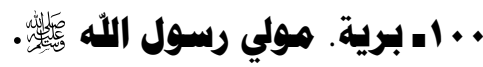
سبق ترجمته رقم ا بأنه مولى رسول الله هوله 0 


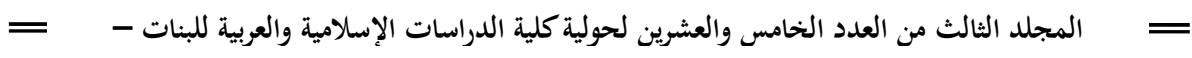

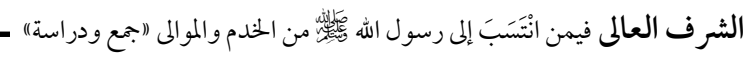

\section{المبحث الثالث}

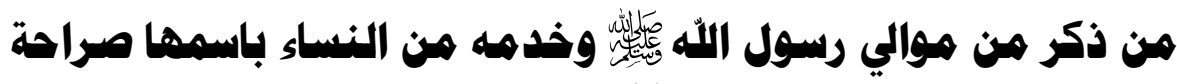

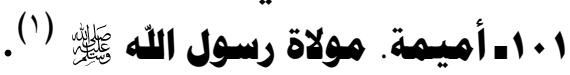
قال ابن عبد البر : روى عنها: جبير بن نفير الحضرمى حديثها عند أهل

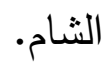

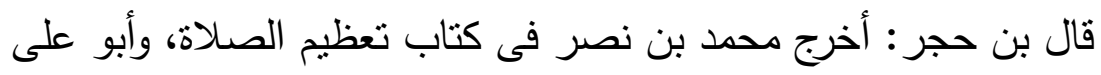
بن السكن، والحسن بن سفيان فى مسنده وغيرهم، وأنشار إليه الترمذى في الئى

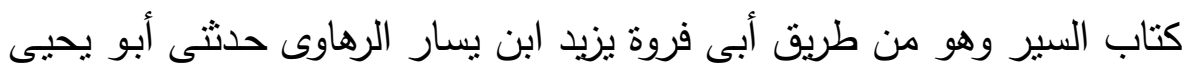

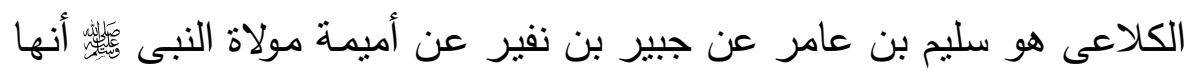

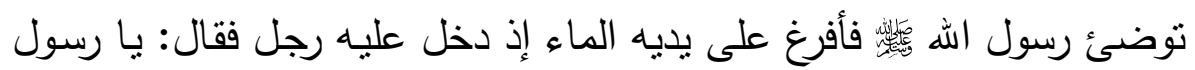

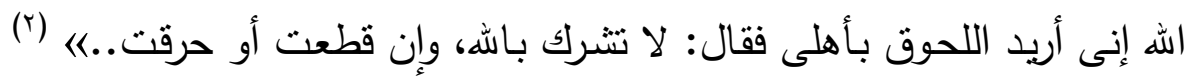
الحديث

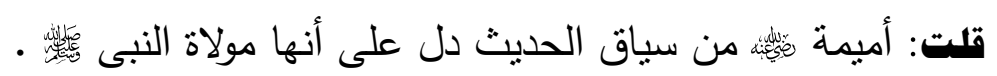

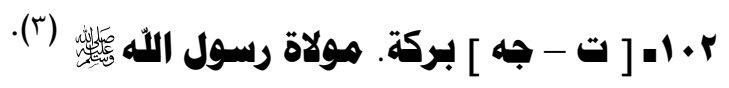

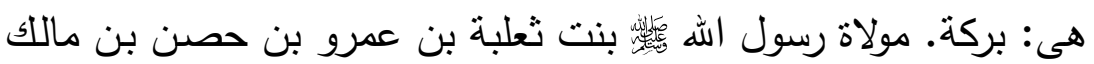

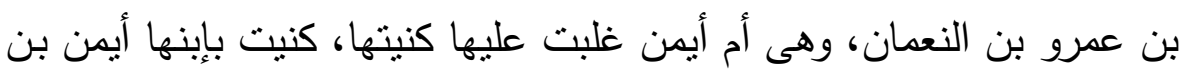

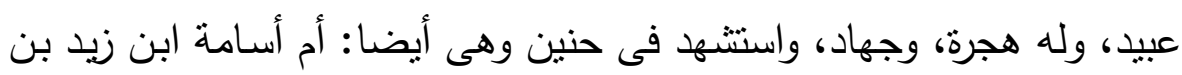
حارثة تزوجها زيد بعد عبيد الحبشى. هاجرت الهجرتين.

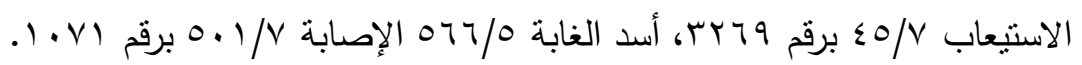

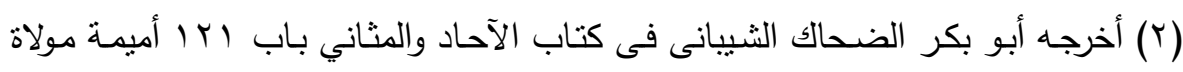

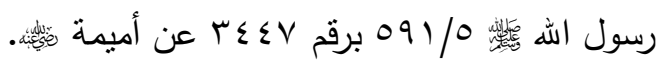

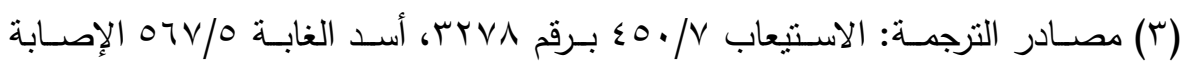

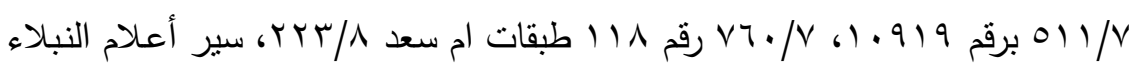

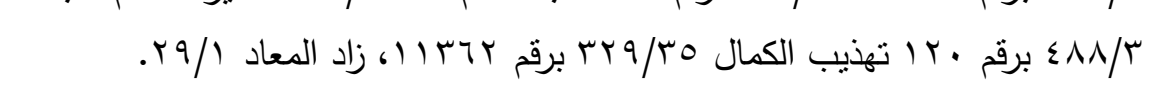




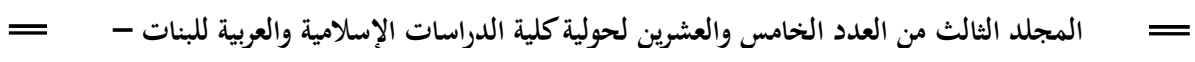

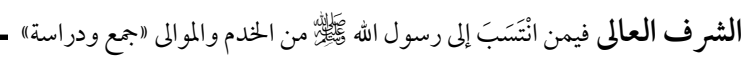

روت عن النبى

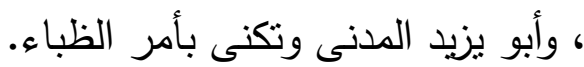

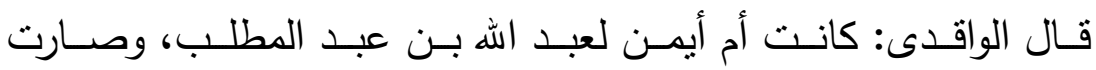

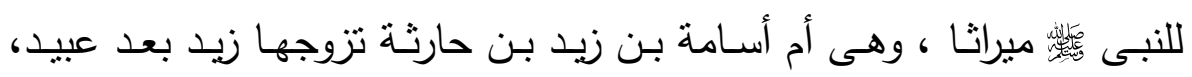
حضرت أحدا، وكانت تسقى الماء، وتداوى الجرحى، وشهدت خيبر ماتت أم أيمن فى خلافة عثمان.

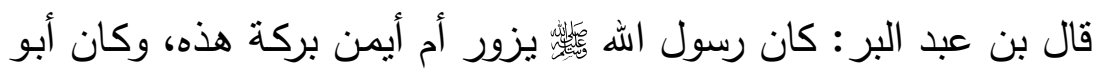

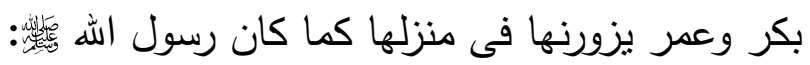

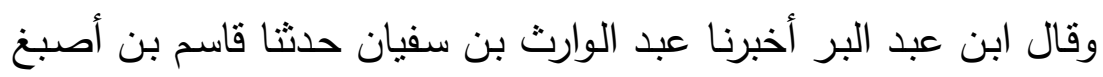
حدثنا أحمد بن زهير حدثنا سليمان ابن أبى شيخ قال: أم أيمن اسمها بركة، أبنا

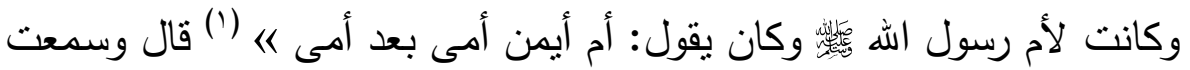

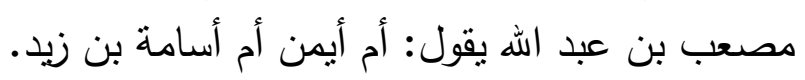

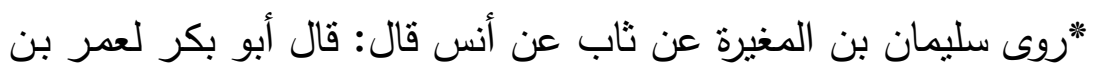

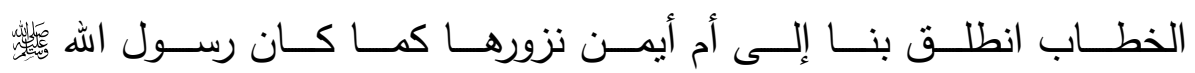

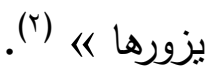

"وأخرج ابن السكن من طريق عبد الملك بن حسين ابى مالك النجعى

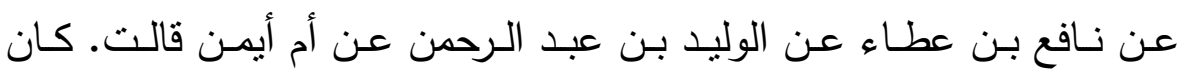
للنبى عطشانة، فغلطت فشربتها فذكر للنبى

هذا « (r) (ن)

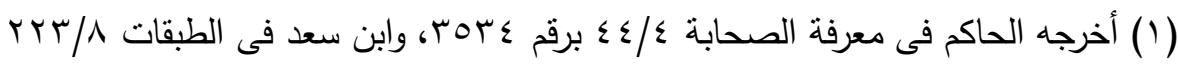

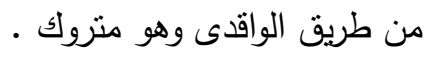

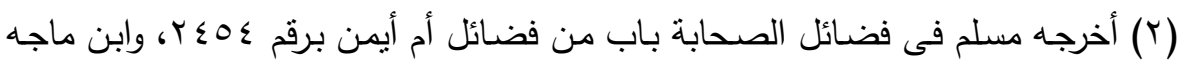

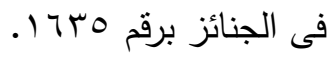

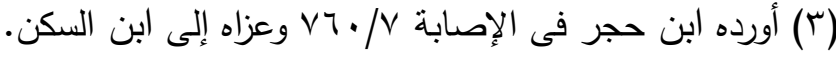
$1 \leq 9$ 


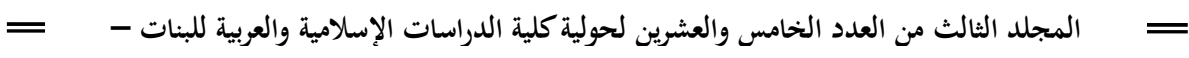

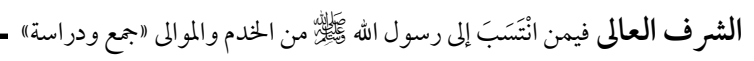

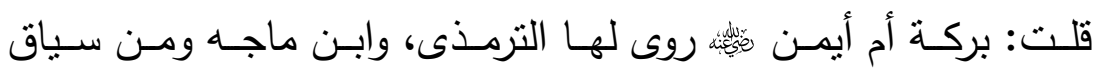

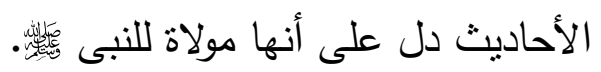

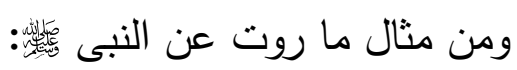

بما أخرجه ابن ماجة رحمه الله تعالى: حدثنا بعقوب بن حميد بن كاسب

حدثنا ابن وهب أخبرنى عمرو بن الحارث أخبرنى بكر بن سوادة أن حنش بن

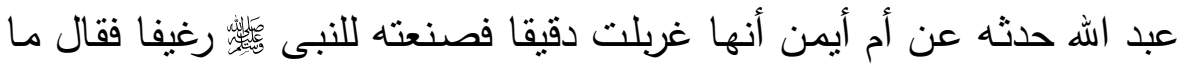
هذا قالت طعام نصنعه بأرضنا فأحببت أن أصنع منه للك رغيفا فقال رديه فيه

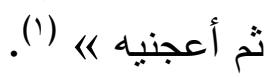

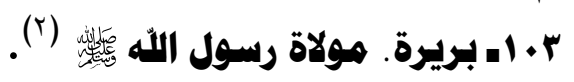

قال ابن أبى شيبة حدثنا وكيع عن المنذر بن ثعلبة عن عبد الله به بريرة

قال: كان رسول الله

بالسوالك اه

قلت: بريرة نِئئه من سياق الحديث دل على أنها مولاة رسول الله

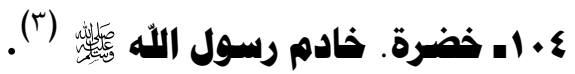

ذكرها ابن سعد، وأسند الواقدى من حديث سلمى أم رافع بسنده إلبها

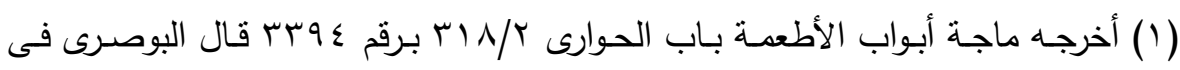

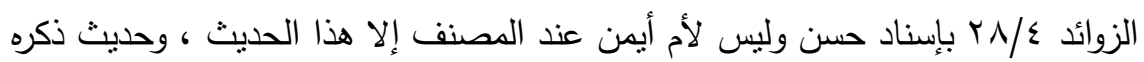

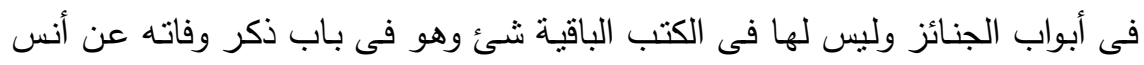

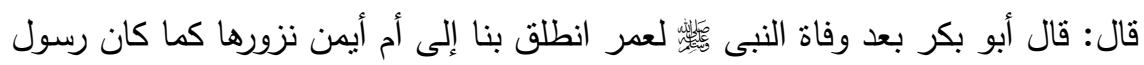

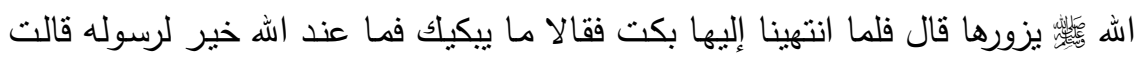
إنى لأعلم أن ما عند الله خير لرسوله ولكن أبكى لأن الوحى انقطع من السماء قال

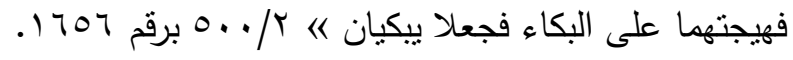

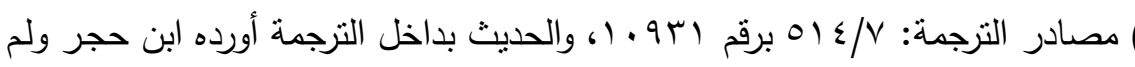
أقف على تخريجه.

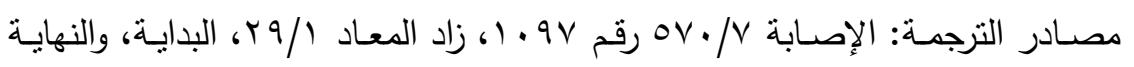

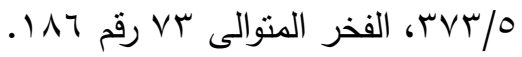

$10 \cdot$ 


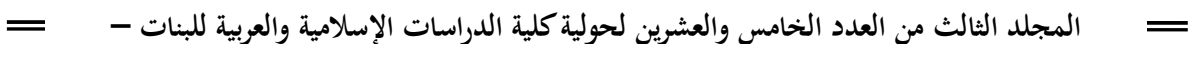

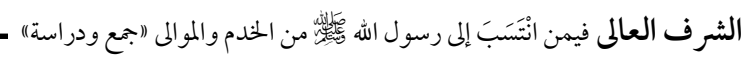

قالت: كان خدم رسول الله

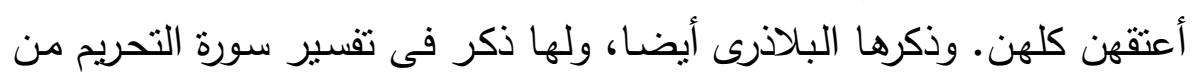
كتاب مردويه. قلت: خضرة نئئن: ومن سياق رواية الواقدى نص على أنها مولاة رسول الله ه

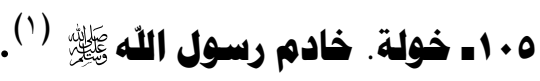

قال ابن عبد البر : روى حديثها حفص بن سعيد عن أبيه عنها فى تفسير سورة الضحى، وليس إسناد حديثها مما يحتج باله

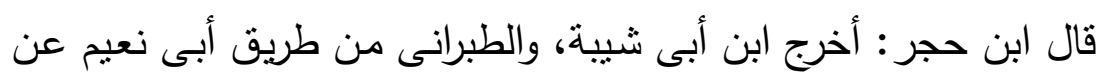

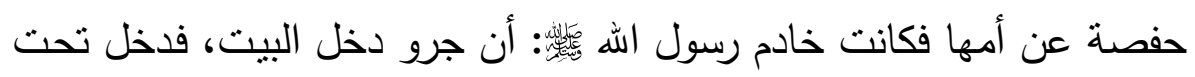
السرير ومكث النبى لئس

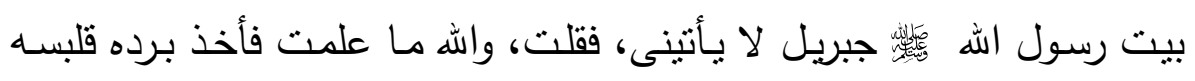

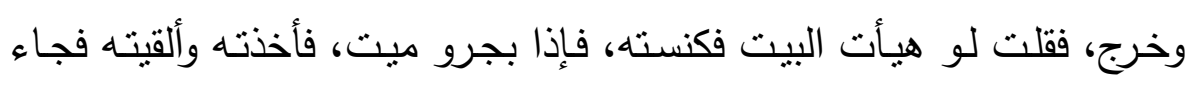

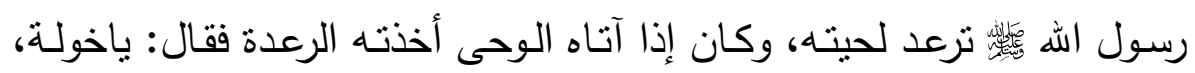

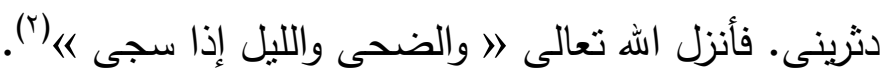

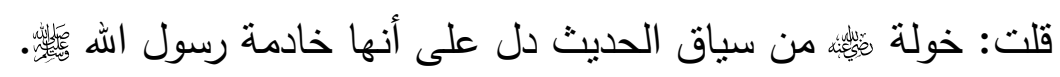

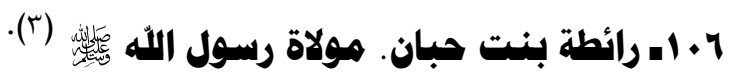

هى رائطة بنت حبان بن عنزة بن ناشرة من سبى هوازن، وهبوله وهبها رسول

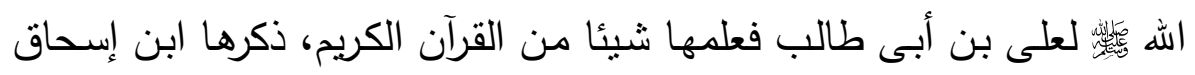
فى رواية يونس بن بكير وغيره عنه.

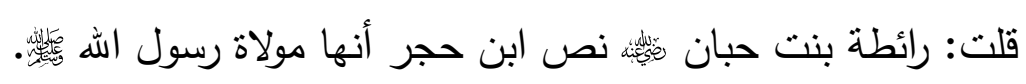

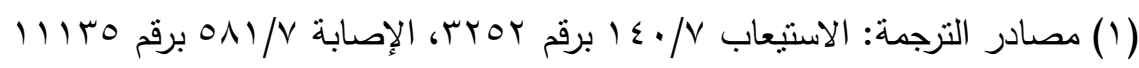

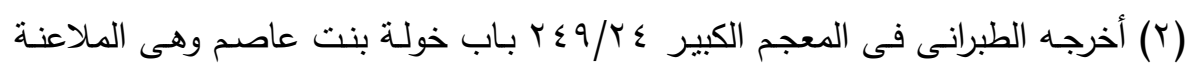

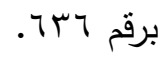

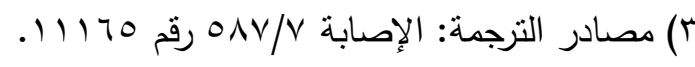
= 101 番 


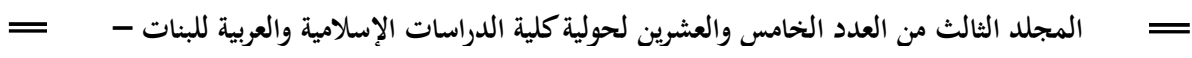

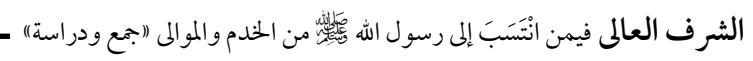

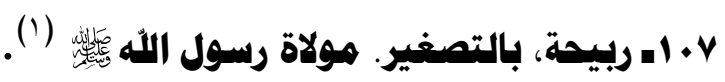

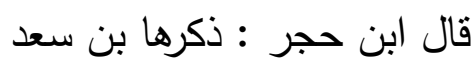

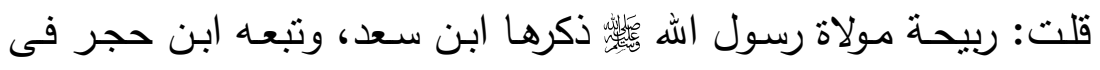

أنها مولاة رسول اله له كولاة.

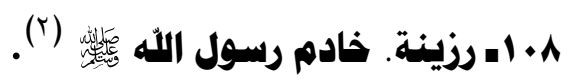

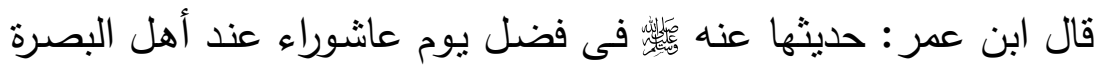

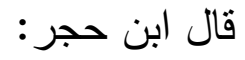

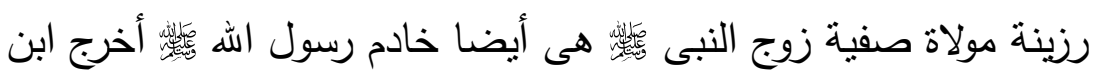

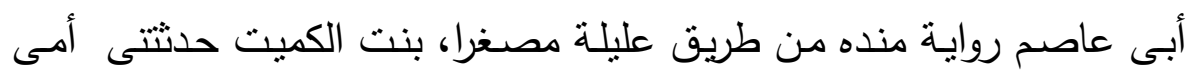

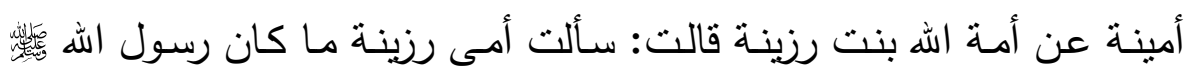

يقول فى صوم عاشوراء قالت: إنه كان ليصومه فيأمرنا بصيامه (َ).

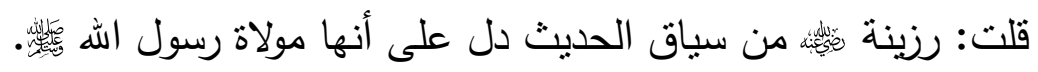

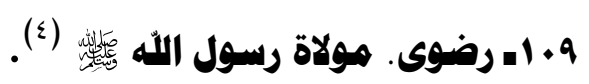
قال ابن حجر • تقدم ذكرها في خضرة.

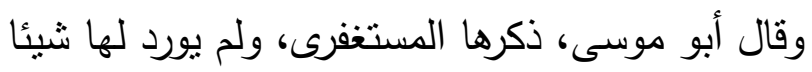

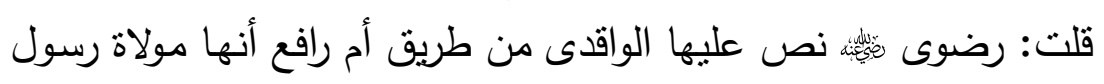

اله

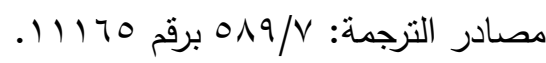

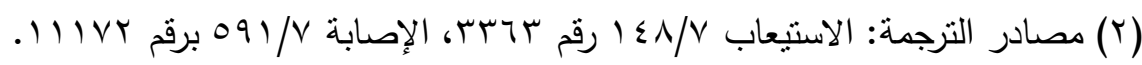

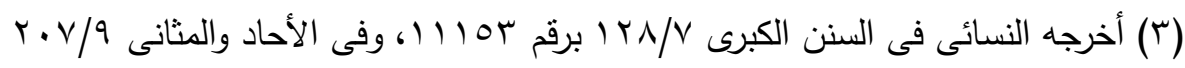

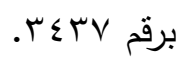

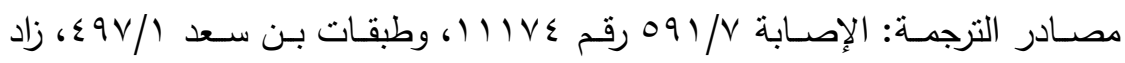

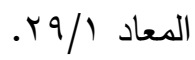

100 


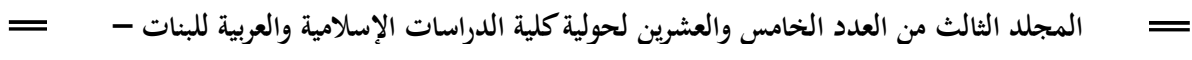

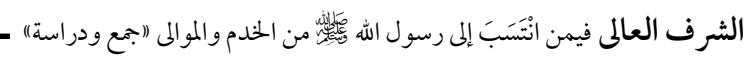

. 11 .

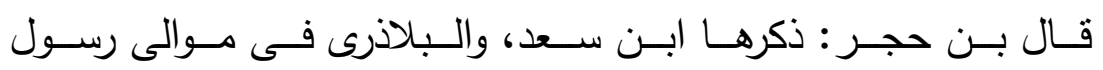

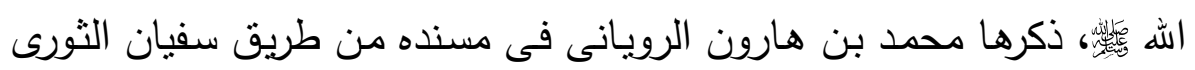

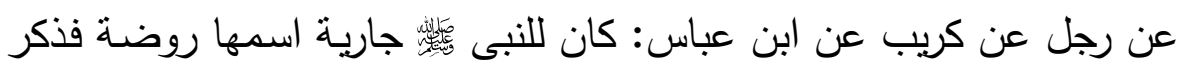
حديثا طويلا.

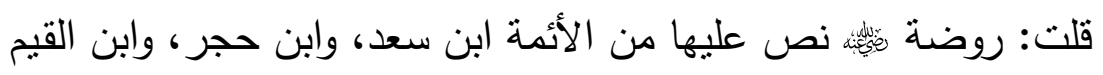

أنها مولاة للرسول فئ.

(「)

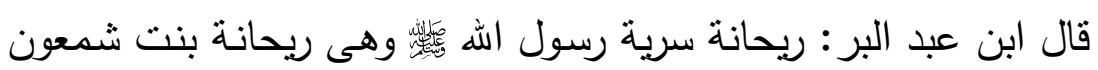

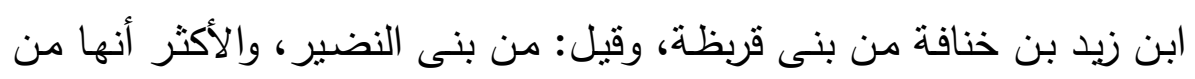

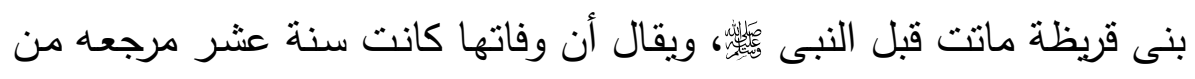
حجة الوداع. (r)

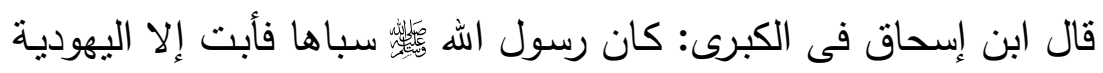

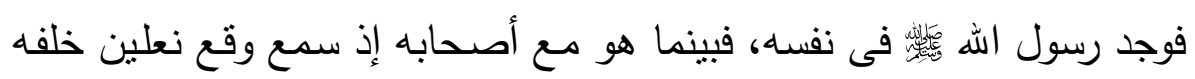

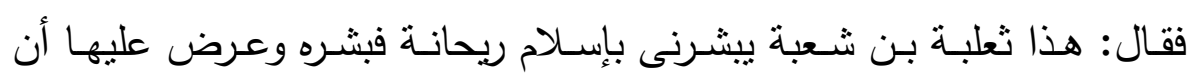

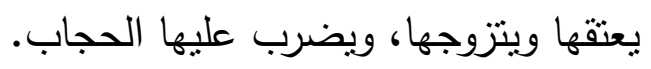

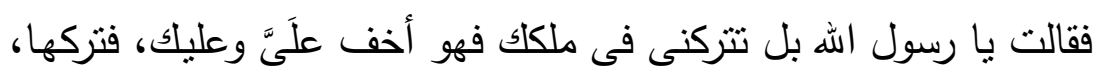

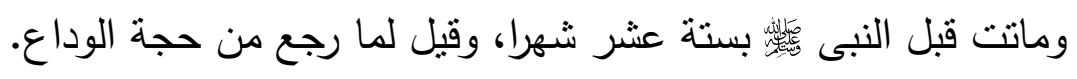

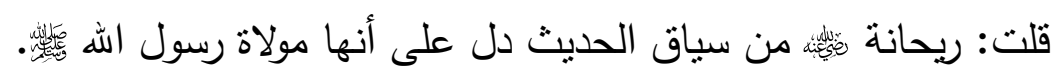

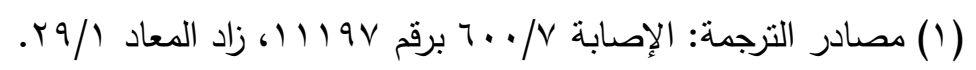

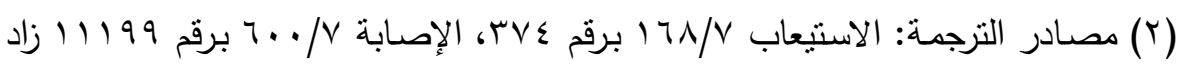
المعاد / T9/T.

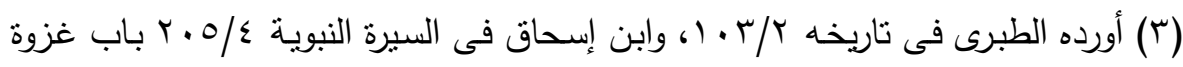
بنى قريطة. lor sos 


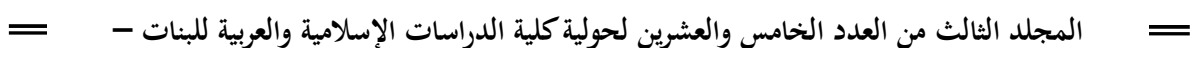

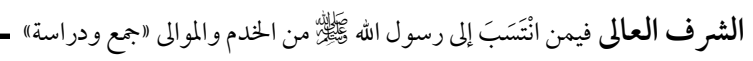

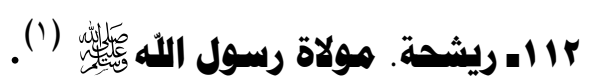

ذكرها بن القيم فى موالى رسول الله له له لم ولم أقف على غير ذلك.

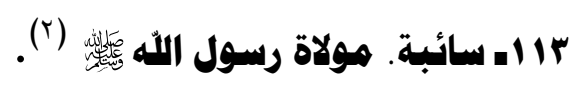

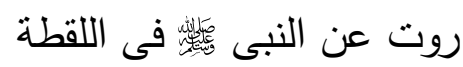

روى عنها: طارق بن عبد الرحمن فى تاريخ النساء، وكذا فى الذيل لأبى

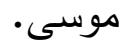

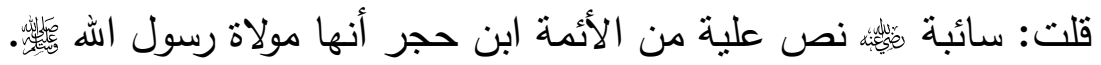

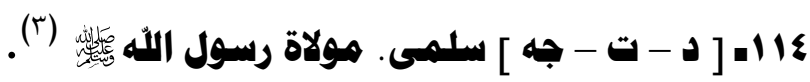

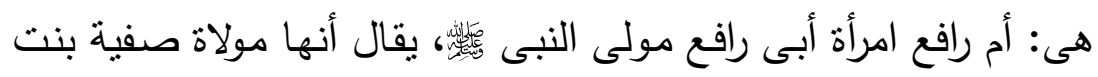

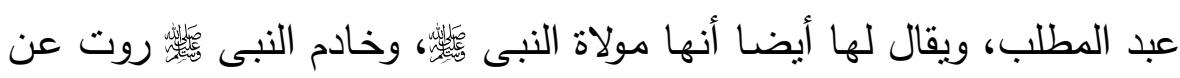
النبى

روى عنها: ابنها عبيد الله بن على بن أبنى أبى رافع.

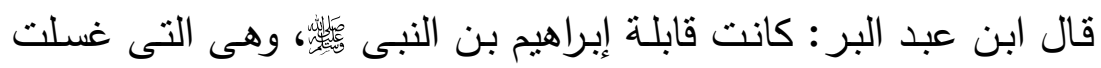

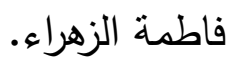

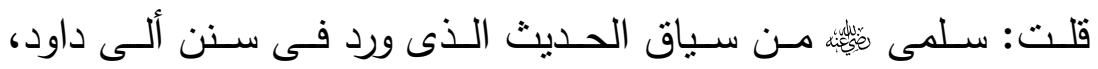

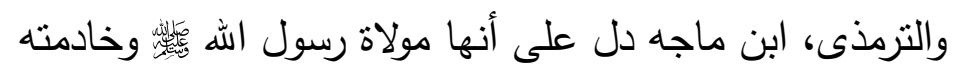

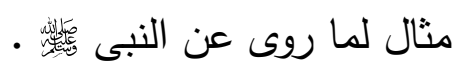

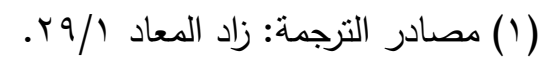

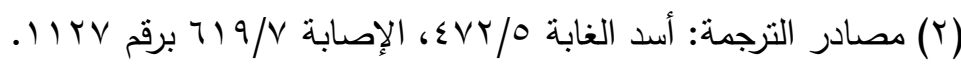

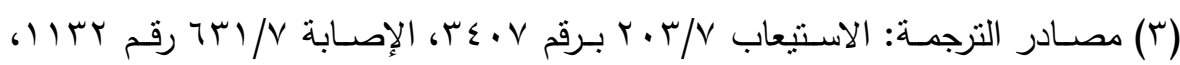

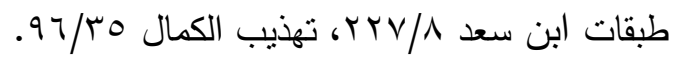
$=10 \%$ is 


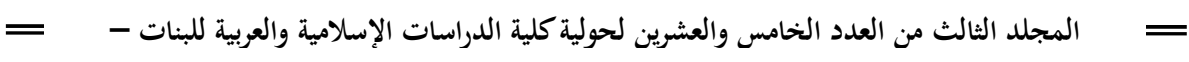

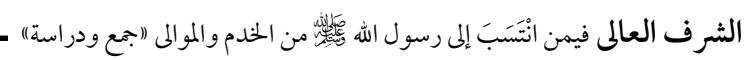

بمـا أخرجها ابن ماجـة رحمـه الله تعـالى : حدثنا عن الرحمن بن إبراهيم

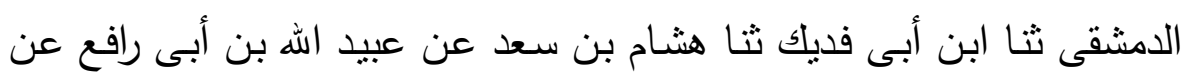

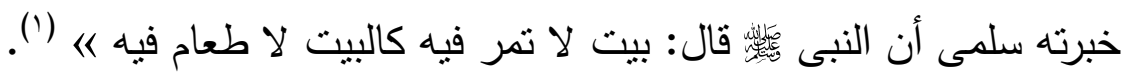
وأخرجها الترمذى فى الأطعمـة عن عائشـة وفى الباب عن سلمى امرأة أبى رافع وقال هذا حديث حسن غريب من هذا الوجـه لا نعرفه من حديث هشام من عرفه إلا من هذا الوجه. وما رواه الترمذى من طريق فائد مولى أبى رافع عن علم بن عبيد الله هن هاله

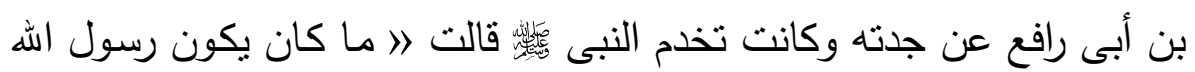

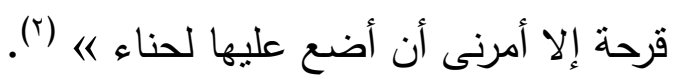

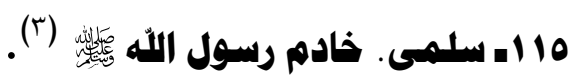
وقع ذكرها فى ترجمة زينب بنت جحش من طبقات بن سعد فى خبر رواه عن الواقدى، عن عبد الله بن عامر الأسلمى عن محمد بن يحيى ابن

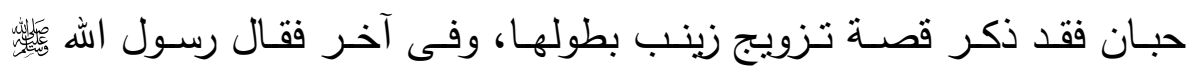

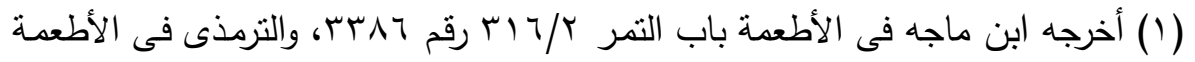

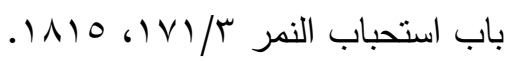

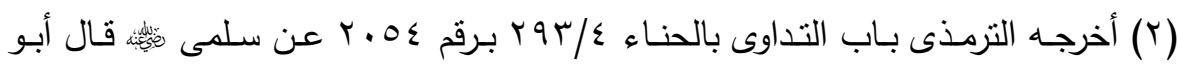

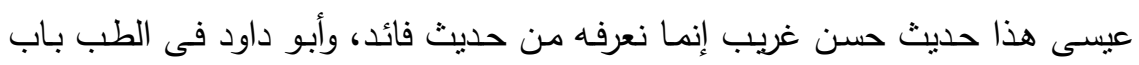

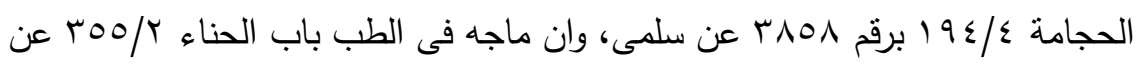
سلمى مولاة رسول الهه

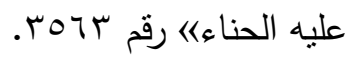

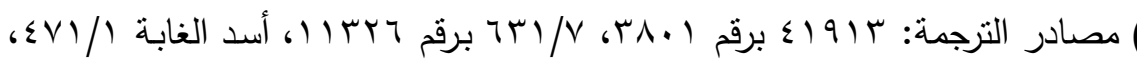

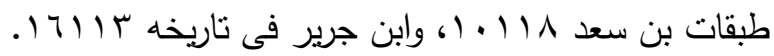

$\overline{=} 100$ 率 


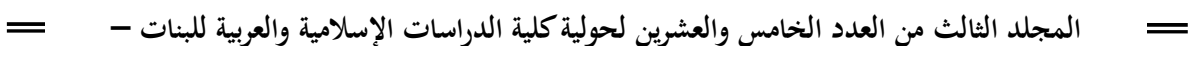

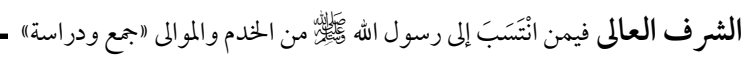

| ال من يذهب إلى زينب يبشرها أن الله زوجنيها قالت فخرجت سلمى خـادم

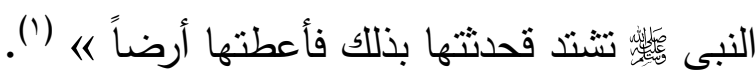

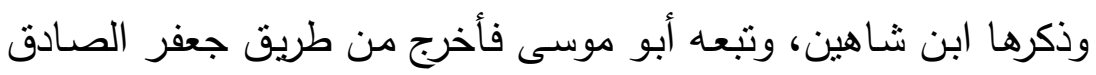

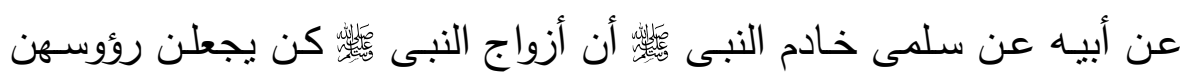

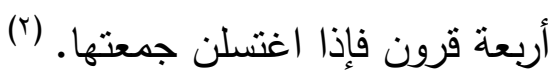

قلت: سلمى من سياق الروايات دل على أنها خادم رسول الله ئس

(117)

قال ابن عبد البر : سبرين أخت مارية القبطية أهداها المقوقس صاحب

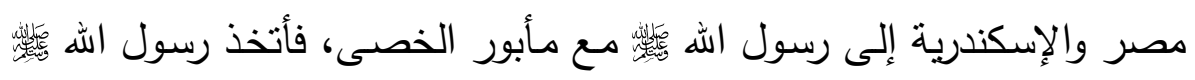
ماريـة لنفسه، ووهب لحسان ابن ثابت وهـى أم عبد الرحمن حسان بن ثابت. روى عنها عبد الرحمن حسان قالت:

رأى رسول الله تضـر ولا تتفع ولكن تقر عين الحى، وإن العبد إذا عمل شيئًا أحب الله أن

يتقنه

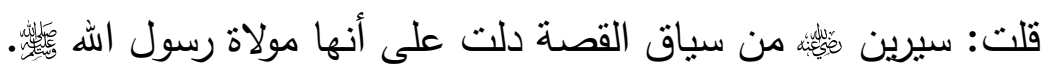

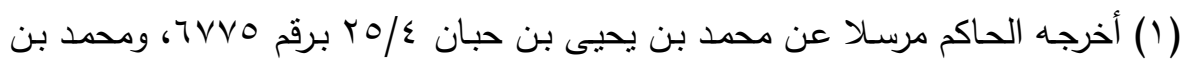

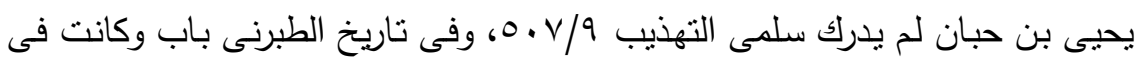

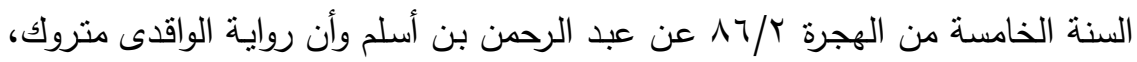

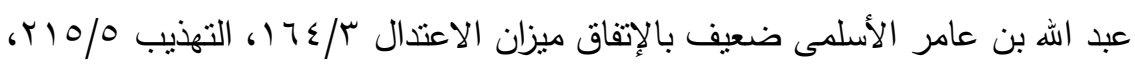

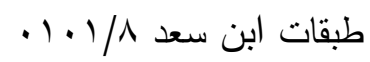

(r) اورده ابن حجر فى الإصـابة ولم أقف على تخريجه وأورده، وابن سعد فى الطبقات، وكذلك اردي

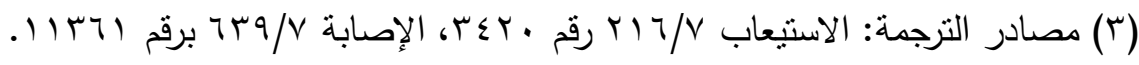

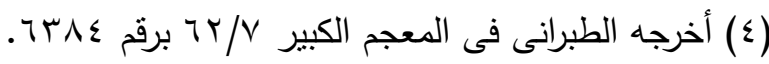




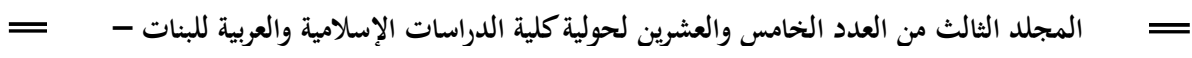

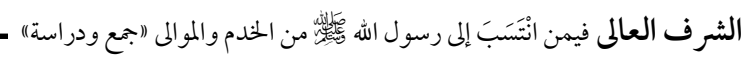

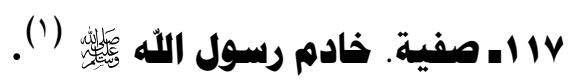

روت عنها أمة الله رزبنة فى الكسوف مرفوعاً

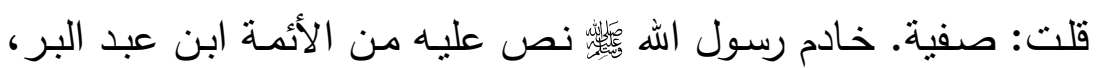

وابن حجر أنها مولاة رسول الله

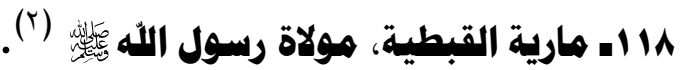

أم ولده إبراهيم. وهى: ماربة بنت شمعون أهداها لـه المقوقس، القبطى هوه

صساحب الإسكندرية ومصر فى سنة V من الهجرة، مع حاطب بن أبى بلتعة

فعرض حاطب على ماربة الإسـلام ورغبها فيه فأسلمت، وأسلمت أختها، وأقام

الخصى على دينه حتى أسلم بالمدينة بعد فى عهد رسول الله فئليَّة.

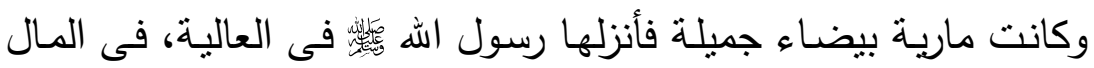

الذى صار يقال له سرية إبراهيم، وكان يختلف إليها هناك، وكان يطؤها بملك اليمين وضـرب عليها مـع ذلك الحجاب، فحملت منه ووضـت هنالك فى ذى الحجة سنة مهـ

ومـن طريـق عمـرة عن عائثـة قالت: مـا غرت على امـرأة إلا دون مـا

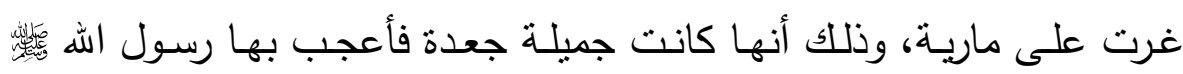
وكان أنزلها أول ما قدم بها فى بيت لحارثة بن النعمان، وكانت جارتتا فكان عامة الليل والنهار عندها حتى فزعنا لها، فجزعت فحولها إلى العالية، وكان يختلف إلبها هنالك فكان ذلك أثد علينا. قال الواقدى: حدثنى موسـى بن محمد بـن إبراهيم عن أبيـه قال: كان أبوبكر ينفق على مارية حتى مات، ثم عمر حتى توفيت فى خلافته وصلى

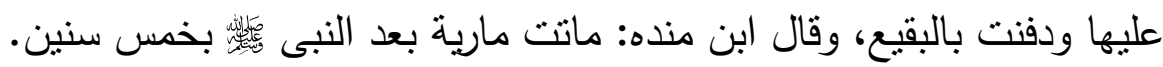

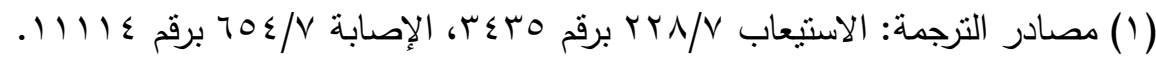

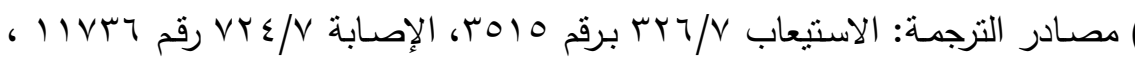

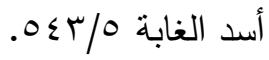

$10 \mathrm{~V}$ 


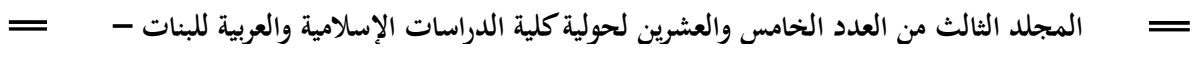

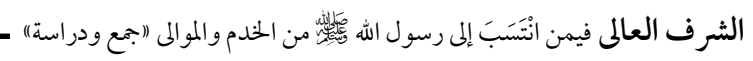

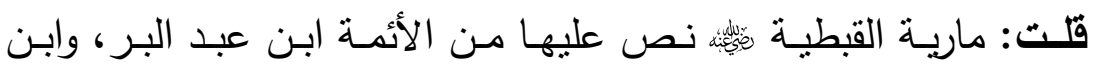

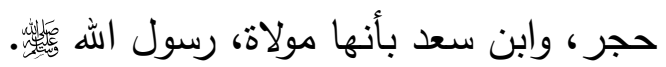

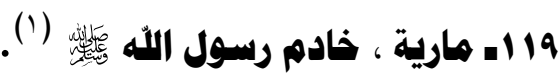

قال ابن عبد البر : تكنى بأم الرباب، وحديثها عند أهل البصـرة: أنها

تطأطات النبى

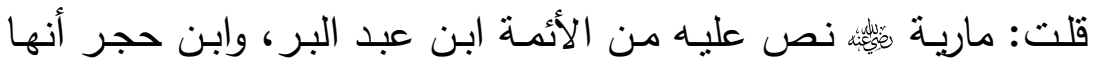

خادم رسول الله

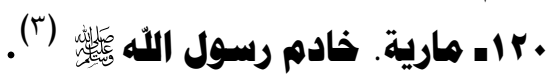

هى جدة المثنى بن صالح بن مهران مولى عمر وابن حريث لها حديث

$$
\text { واحد عند أهل الكوفة. }
$$

ورواه أبو بكر بن عباس عن المثنى بن صالح عن جدته ماربة قالت:

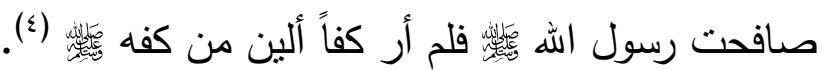

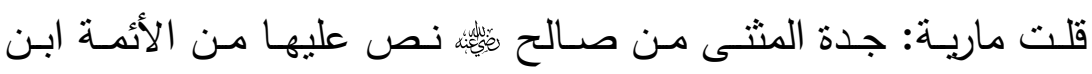

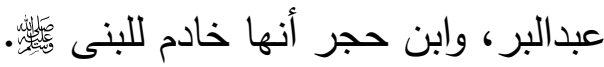

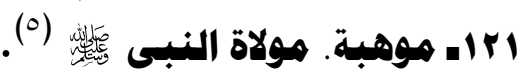

وقع ذكرها فى حديث أبى نضرة الغفارى فى نص إسلامه:

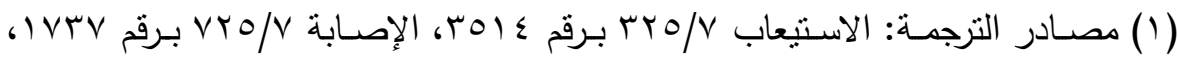

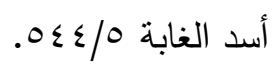

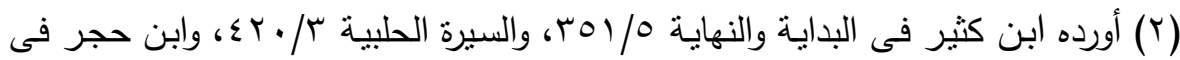

$$
\text { الإصابة VO V ولم أقف على تخريجه. }
$$

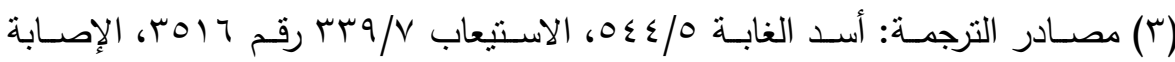

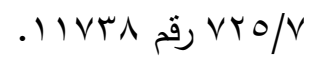

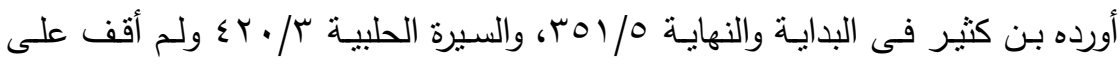

$$
\text { تخربجه. }
$$

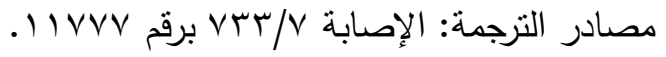




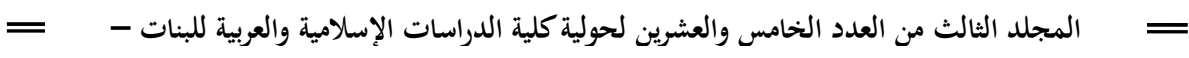

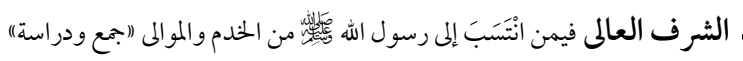

وفيه: (ا... فدعا موهبة بعير فحلبها فسقانى، فكأنى لم أشرب شيئا، ثم

دعا بأخرى إلى أن قال: فغضبت موهبة فأبغضنتى ا/(').

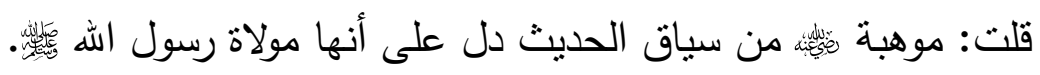

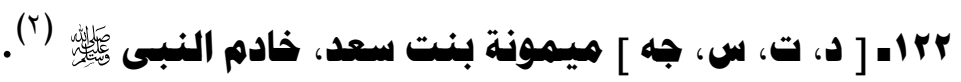

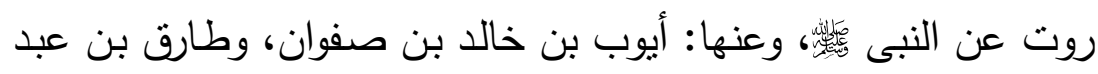

الرحمن وهلال بن أبى هلال المدنى، وأبو يزيد الضبى وآخرون.

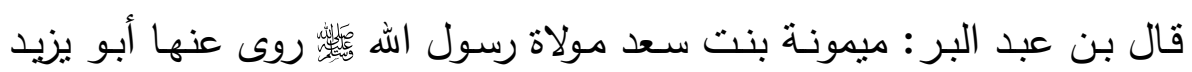
الضبى بن خالد حديث مرفوعا فى قبلة الصائم (r) وعتق ولد الزنا (ء) وليس سنده بالقوى.

وقال ابن حجر فى التهذيب: قبل إن التى روت عنها عثـان بن زبـاد

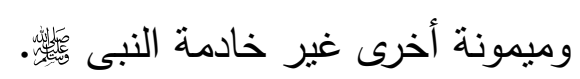

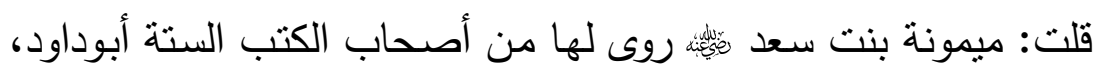
والترمذى و النسائى، وابن ماجة ونص عليها من الأئمة ابن عبد البر، وابن

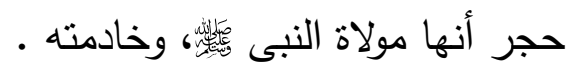
ومن مثال ما روت عن النبى فوله

(1) أورده صاحب كتاب فتوح مصر باب اكرام الضيف باب من قال الضيافة ثلاثة / / عـ.

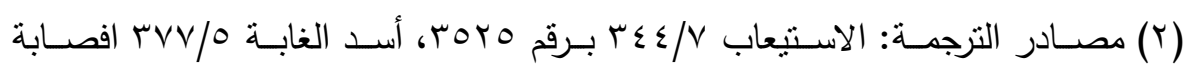

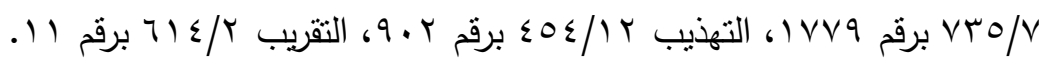

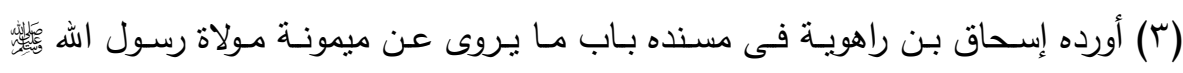

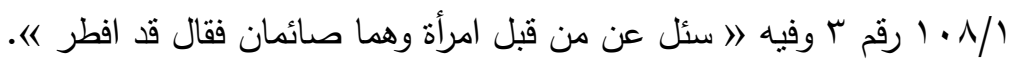

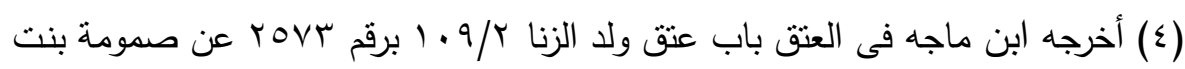

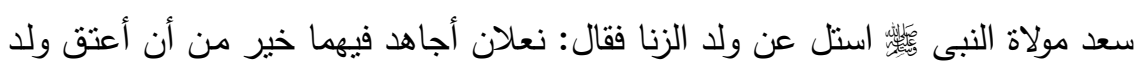
الزنا فى الزوائد ابو يزيد الضبى قال عبد الغنى منكر الحديث، وقال البخارى: مجهول وقال الذهبى والدار قطنى: ليس بمعروف. 


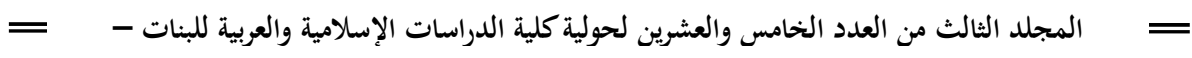

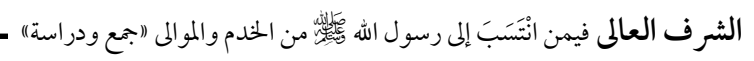

مـا أخرجه الترمذى قال حدثتا على بن خرشّم أخبرنـا عيسى بن بونس

عن موسىى بن عبيده ابن خالد عن ميمونة بنت سعد فكانت خادم النبى

قالت قال رسول الله

》 منل الرافلة فى غير أهلها كمنل ظلمة يوم القيامة ) (1)

قال أبو عيسى هذا حديث لا نعرفه إلا من حديث موسى عبيده، وموسى

ابن عبيده يضـعف فى هذا الحديث مسن قبـل حفظله وهو صدوق، وقد رواه

بعضهم عن موسى بن عبيده ولم برفعه.

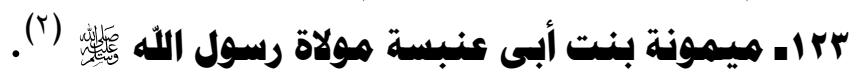

قال ابن عبد البر : روت عن النبى

وقال ابن منده: ميمونة بنت عنبسة، ويقال بنت أبى عنبسة مولاة رسول

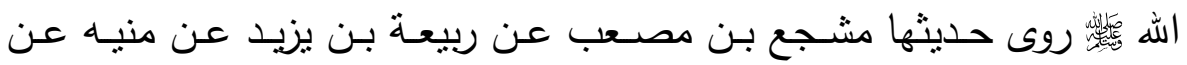

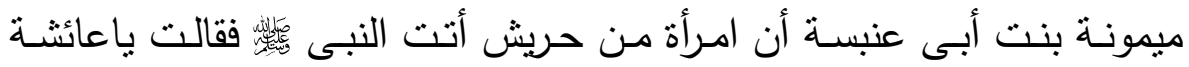

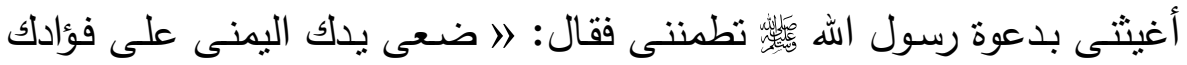
فأمسحيه وقولى [ اللهح داونى بدوائك، واشفنى بشفاك، وأغننى بفضلك عمن سوالك ] (r) قال ربيعة فدعوت به فوجدته جيداً. وصله أبو نعيم من هذا الوجه وقال: ميمونة بنت أبى عسيب.

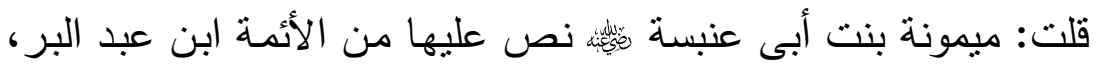

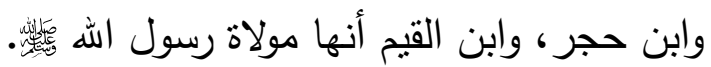

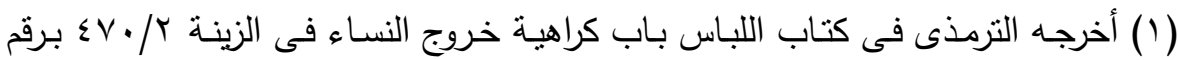
V7 ا ا ـ والرافلة رفل فلان فى ثوبه إذا أطاله وجره على الأرض.

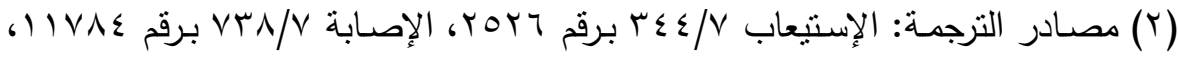

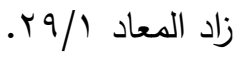

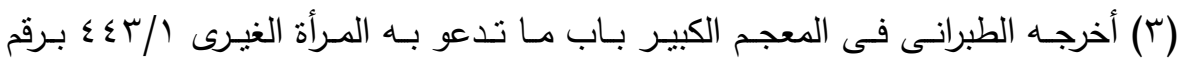

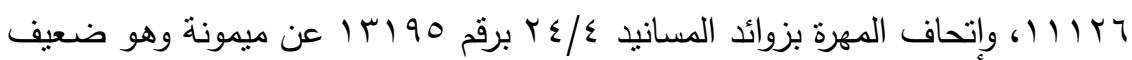
لجهالة روائه. 


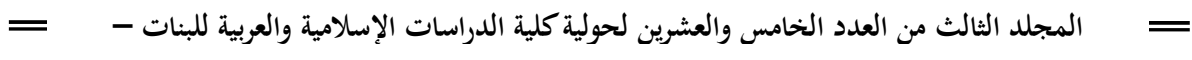

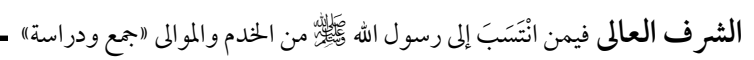

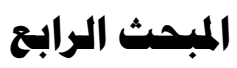

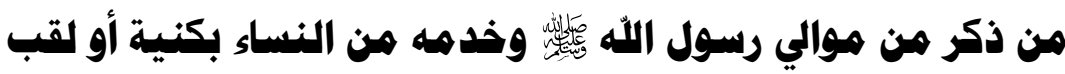

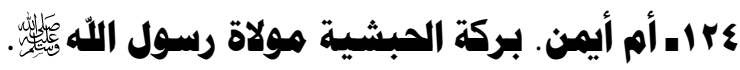

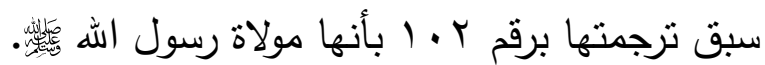

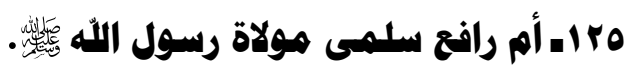

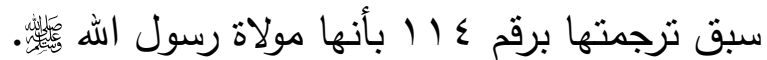

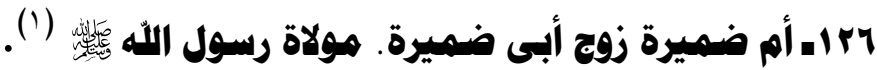

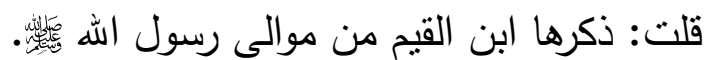

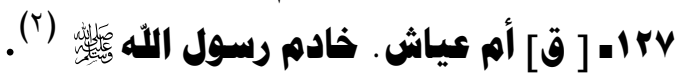

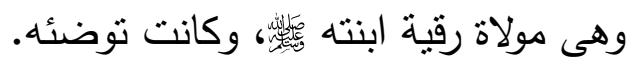

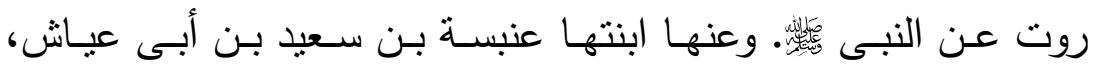
وزوجته أم سلمة بنت موسى.

وروى عبد الواحد بن صفوان عن أبيه عن جدته أم عياش خادم رسول الله

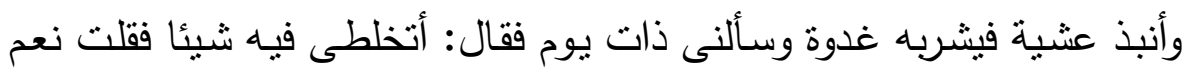
قال فلا تعودى /) ()

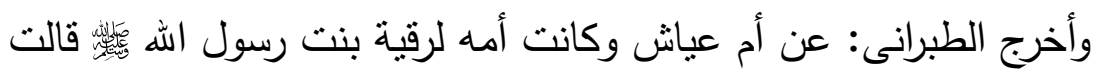

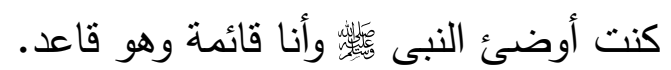

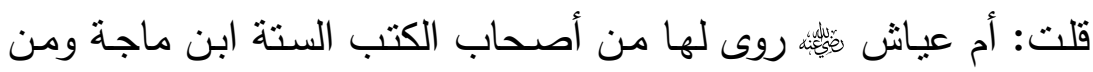

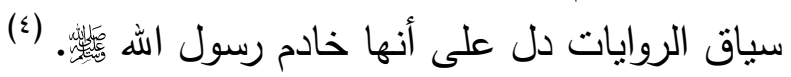

(Y) مصادر الثرجمة: زاد المعاد /9 r.

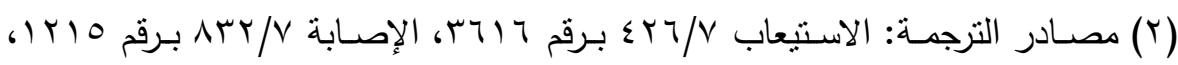

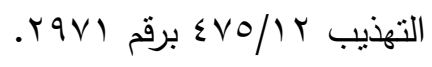

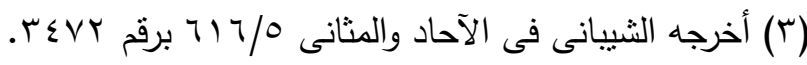

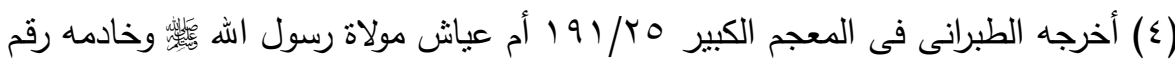
ع זr. وفيه عبد الكريم بن روح ضعيف 


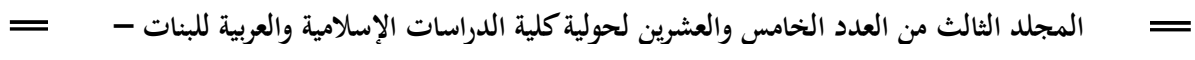

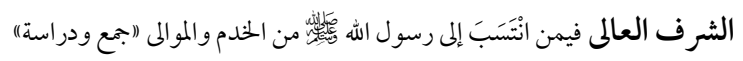

ومن مثنال ما روى لها عن النبى

بما أخرجه ابن ماجة رحمه الله تعالى قال: حدثثا كردوس بن أبى عبد

الله الواسطى حدثنا عبد الكريم بن الروح حدثتا أبى روح بن عنبسة بن سعيد بن أبى عياش مولى عثمان بن عفان عن أبيه عنبسـة بن سعيد عن جدته أم

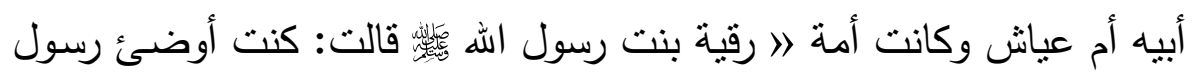

الله

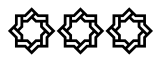

(1) أخرجه ابن ماجه فى الوضوء باب الرجل يستعين على وضونه فيصيب عليه 100/1 19 1 برقم . . ع قال فى الزوائد: اسناده مجهول وعبد الكريم مختلف فيه. وعبد الكريم بن روح

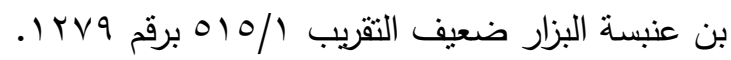

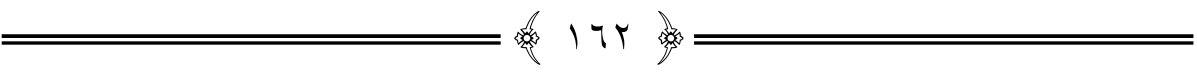




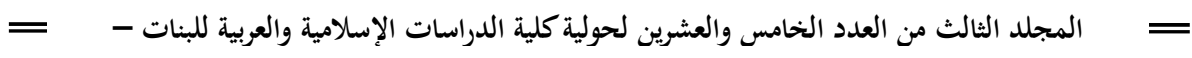

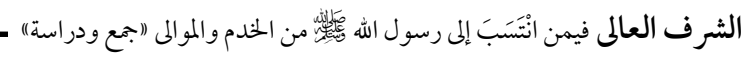

\section{الخاتمة}

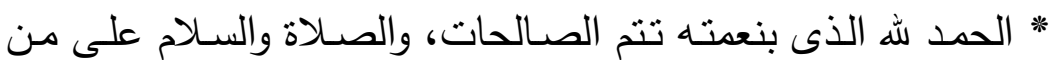

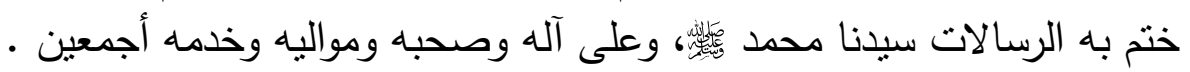

\section{وبعد}

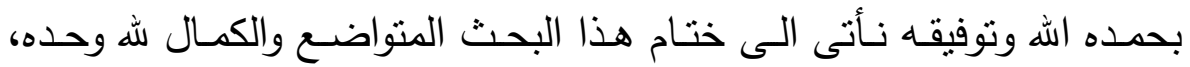

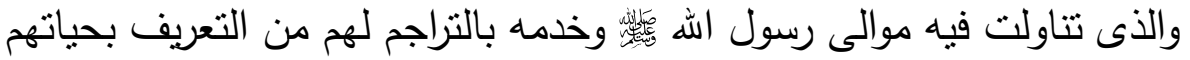

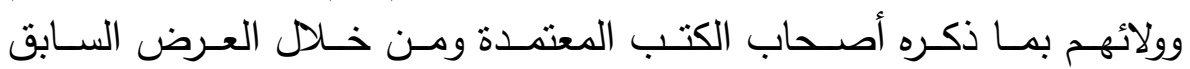
ومصاحبنى لهم حققت النتائج التالية:

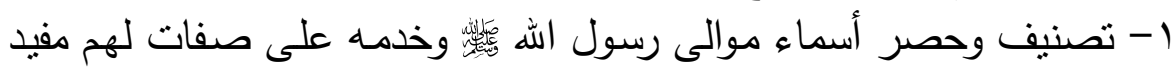
جدا فى أبواب كثيرة ولطائف عديدة من معرفة علوم الحديث منها :-- الأمن

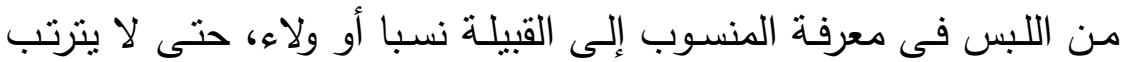

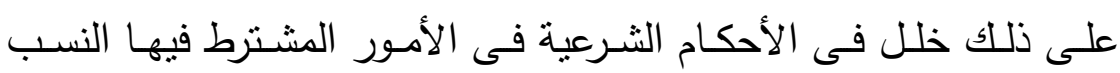
كالامامة العظمى، والكفاءة فى النكاح وغيرها.

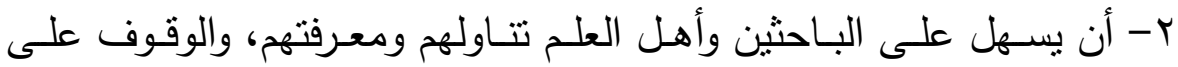

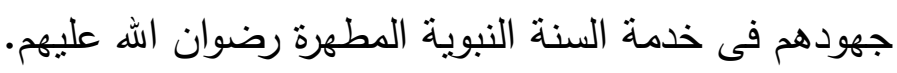

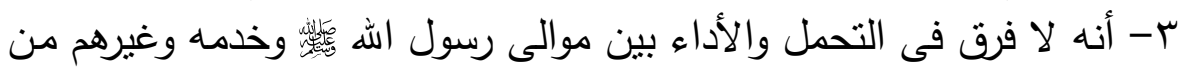

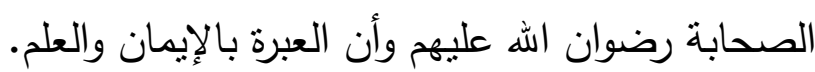

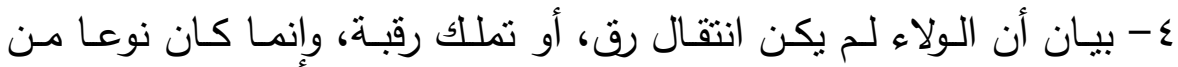

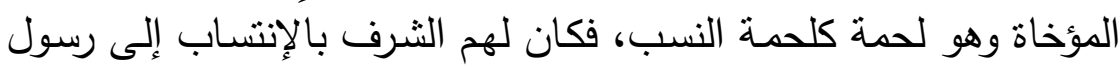
الله 0- أن العز والثرف والأصالة للموالى إنما هو بمواليهم لا بأنسابهم فما أعظم

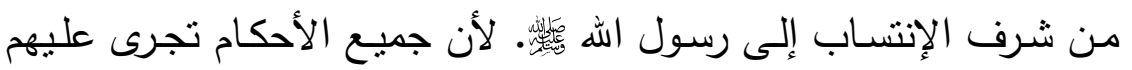

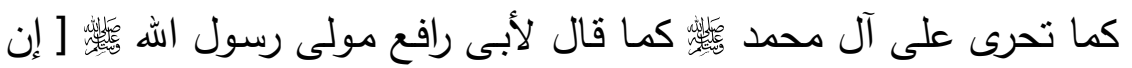

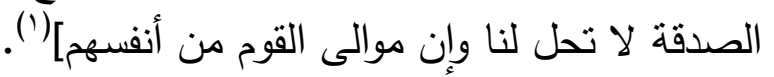

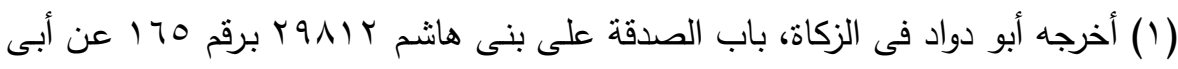

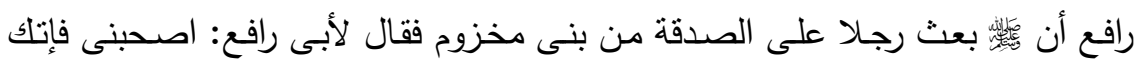

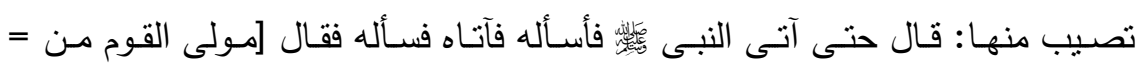




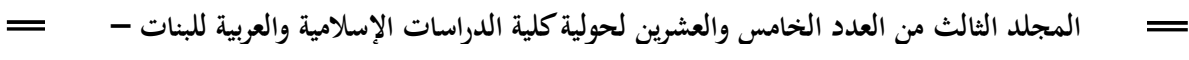

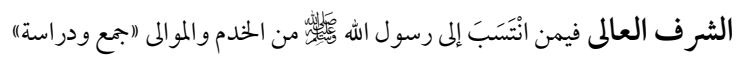

צ- إبراز دورهم فى خدمـة الإسـلام، وجميع نـواحى الحيـاة مـن جهاد وعلم،

وتعلم.

V- أبرزت في تـراجمهم مـا ذكر فـى الكتب المعتمـدة مـن ولانهم وخدمتهم

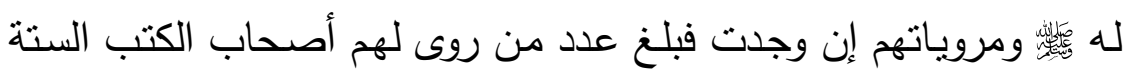

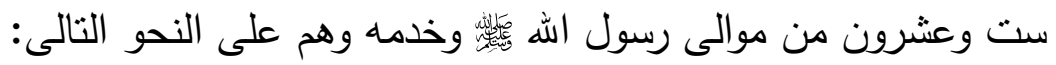

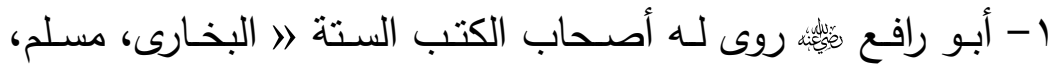

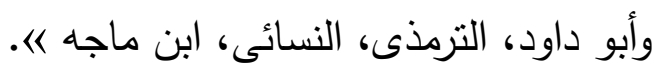

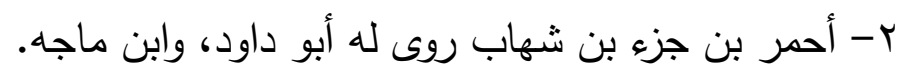
r- أسامة بن زيد روى له جله أصحاب الكتب السنة. ع - أنس بن ماللك روى له أصحاب الكتب السنة. 0- إياد أبو السمح روى له أبو داود، والنسائى، وابن ماجه. 7- باله بن رباح روى له أصحاب الكتب الستة. - ثوبان أبو عبد الله روى له أصحاب الكتب الستة. - حنين روى له النسائى. 9- زيد بن بولا روى له أبو داود، والترمذى. لهن. • 1- زيد بن حارثة روى له النسائى، وابن ماجه.

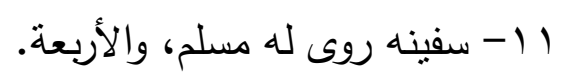
r ا - سلمان الفارسى روى له أصحاب الكتب الستة. rا - شقران روى لله التزمذى. ع ا - شمعون روى له ابو داود، والنسائى، والترمذى. 10 7 ا 1 - عبد الله بن مسعود روى لله أصحاب الكتب الستة. IV =أنفسهر لا تحل لنا الصدقة ] والترمذى فى الزكاة باب ما جاء فى كراهية الصدقة للنبى

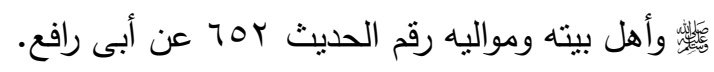




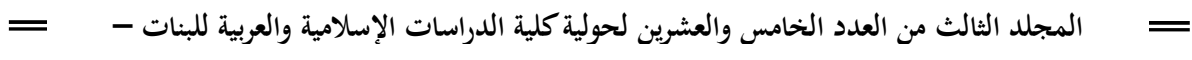

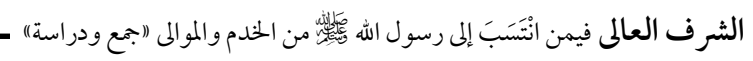

1 ا - قيس بن سعد بن عبادة روى له أصحاب الكتب الستة.

9 1 - نفيع بن الحارث روى له أصحاب الكتب الستة.

• - بسار بن زيد أبو بلل روى له أبو داود، والترمذى.

ا ب- أبو البشير روى لله البخارى، ومسلم، وأبو داود، والنسائى.

r r- أبو الحمراء روى له مسلم، وابن ماجه.

rr- بركة أم أيمن روى لها الترمذى، وابن ماجه.

ع r- سلمى روى لها أبو داود، والترمذى، وابن ماجه.

هr- ميمونة بنت سعد روى أبو داود، الترمذى، النسائى، ابن ماجه.

צr- أم عياش روى لها ابن ماجه.

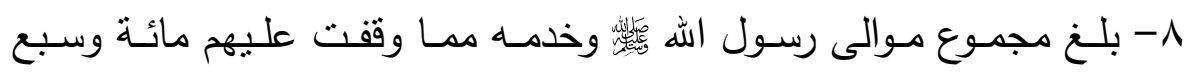

$$
\text { • وعشرون }
$$

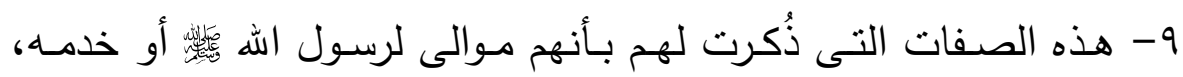
على سبيل التعريف بهم لا التنقيص لهم بل هو وسـام شرف لإنتسابهم •إلى رسول الله

هذا ما أردت بيانه فى خاتمة هذا البحث، وإننى لأرجو الله أن أكون قد وفقت فى كتابته، وما أردت إلا الخير ما استطعت.

وما توفيقى إلا بالله، وآخر دعوانا أن الحمد لله رب العالمين.

د/ الحسينى يوسف عبد العال أحمد 


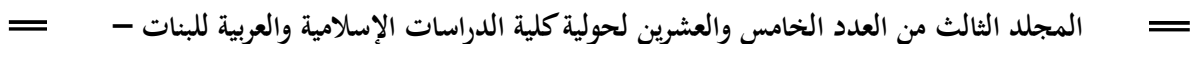

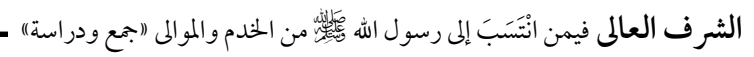

\section{فهرس المصادر والمراجع}

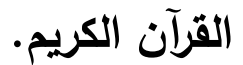

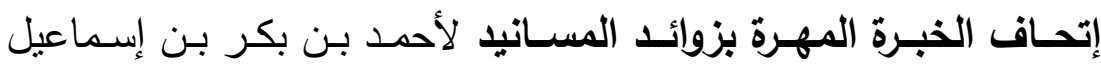

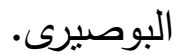

الآحاد والمثانى لأبى بكر الثيبانى أحمد بن عمرو بن الضحاك دارالنشر

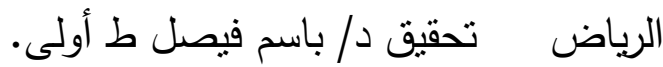

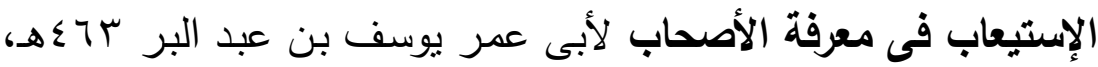

ط دار الغد العربى للطباعة والنشر والتوزيع. التهابعة القاهرة.

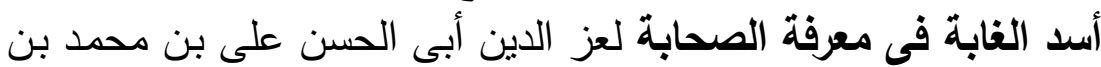

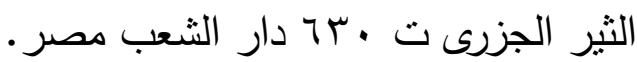

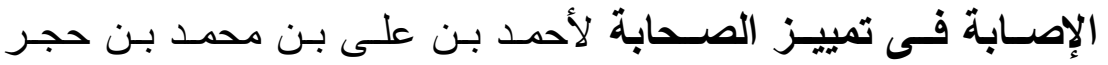

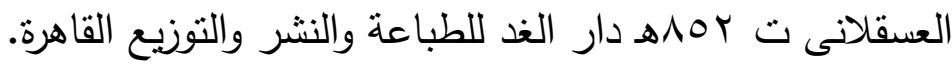
الباعث الحثيث فى اختصار علوم الحديث للحافظ بن كثير عماد الدين

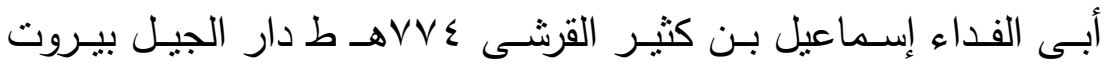
. $) 9 \wedge \mathrm{V}$

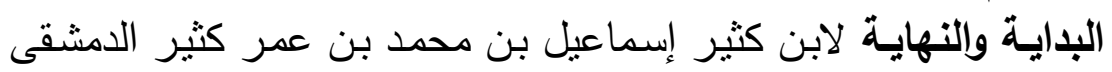
لهـ التاريخ الكبير للبخارى دار الفكر بيروت الفان

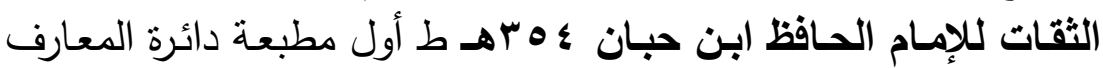

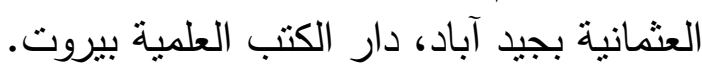

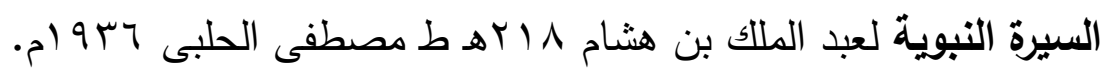

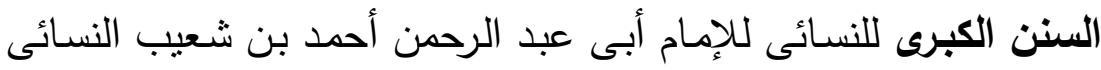

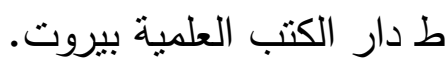
السنن الكبرى للبيهقى لإمام المحدثين الحافظ أبى بكر أحمد بن الحسن

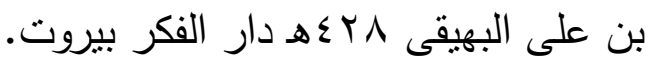

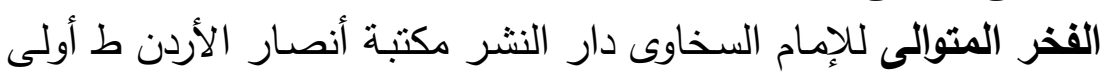
تحقيق الثهور حسن محمود سنة 9 ام. 


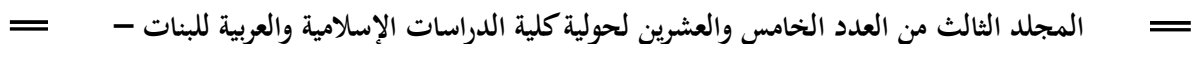

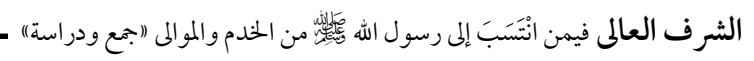

القاموس المحيط للفيروزآبادى لمجد الدين محمد بن بعقوب الفيروزبادى

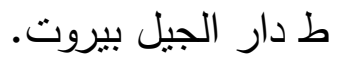
الكامل فى التاريخ على بن محمد بن الجزرى المعروف بإبن الاثير دار الكتاب العربى - بيروت لبنان.

المعجم الوجيز مجمع اللغة العربية بجمهورية مصر لبنان العربية.

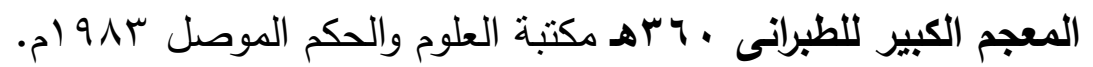

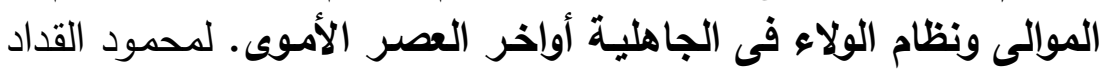

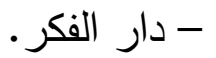
تـاج العروس مـن جـواهر القـاموس للمرتضـى الزبيدى دار النشـر دار الهداية . تاعن العربة

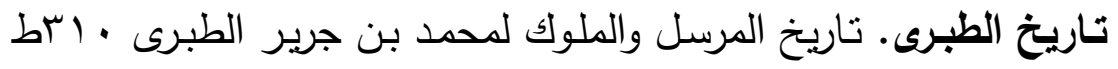

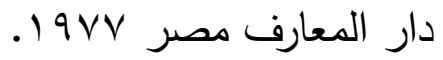

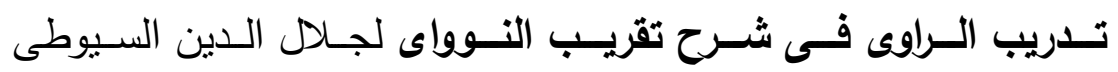
ط دار الكتب الحديثة القاهرة.

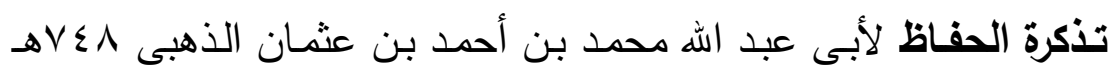
إصابة التراث العربى بيروت.

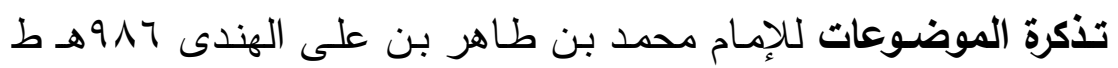

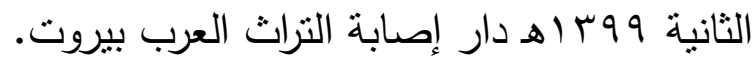

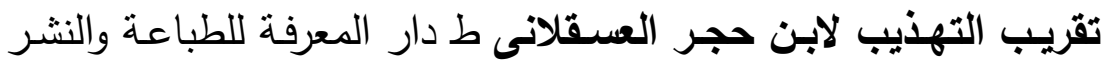
بيروت لبنان. تهذيب الكمال فى أسماء الرجال لأبى الحجاج يوسف على الزكى المزى ت V V V مؤسسة الرسالة بيروت.

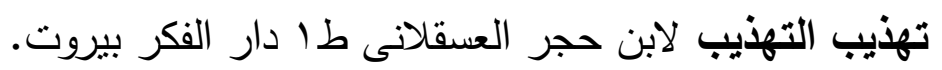

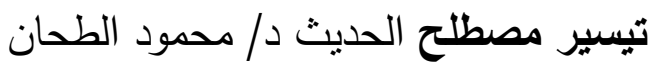

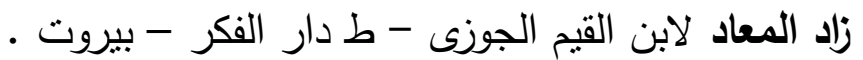

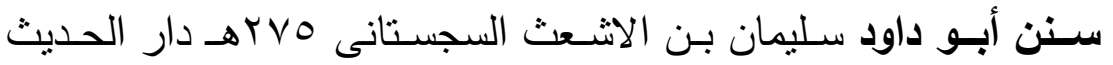
القاهرة. 


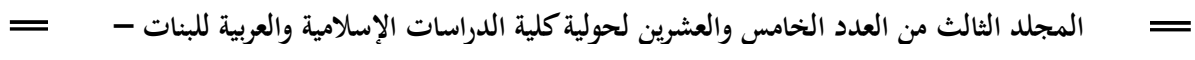

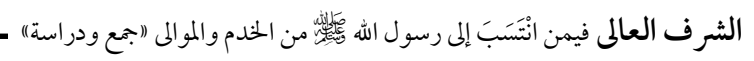

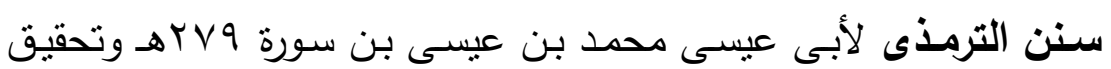

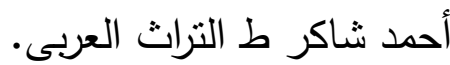

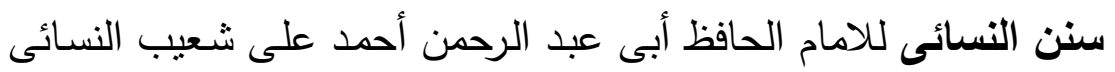

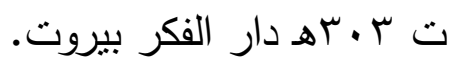
سنن ابن ماجه للحافظ أبى عبد الله محمد بن بزيد القزوينى الفكر بيروت. سنن الدارمى لأبى محمد عبد الله بن مهران الدرامى هـ بهـ دار الفكر بيروت. سير أعلام النبلاء للإمام الذهبى دار الفكر بيروت 99 ام. شعب الإيمان للإمام البيهقى.

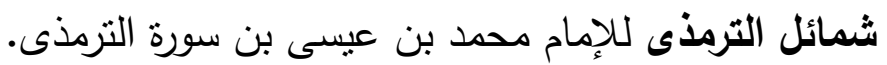

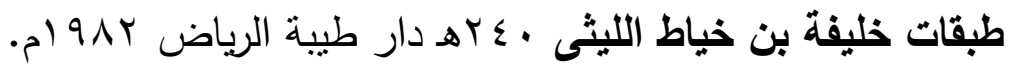

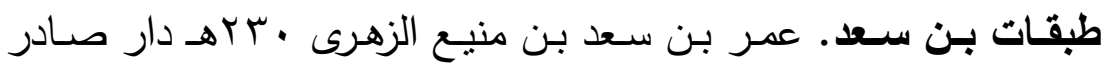
بيروت. عمل اليوم والليلة للامام أحمد بن شعيب النسائى.

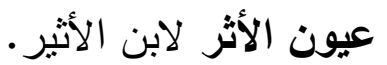
فتح البارى شرح صحيح البخارى لابن حجر العسقلانى ط دار الإفتاء الإني الرياض السعودية. فتح المغيث شرح ألفية الحديث لمحمد بن عبد الرحمن السخاوى ب . وط دار الكتب العلمية بيروت. كنز العمال فى سنن الأقوال والأفعال للمتقى الهندى دار الكتب العلمية بيروت . لسان العرب لابن منظور دار إحياء صادر بيروت .

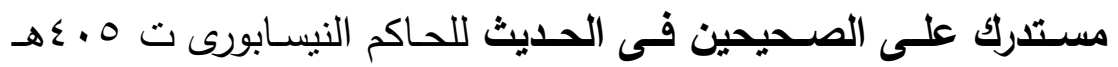

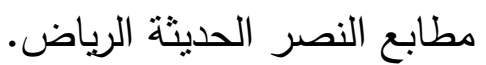

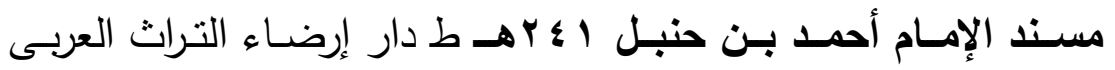
بيروت. 


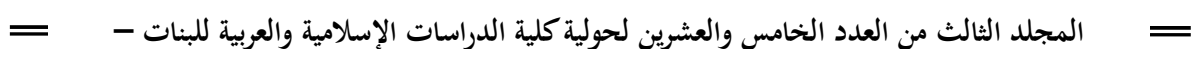

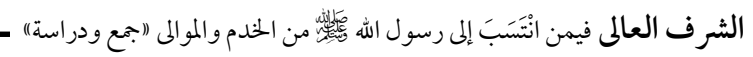

معرفة علوم الحديث لمحمد بن عبد الله الحاكم النيسابورى منشورات دار

$$
\text { الكتب التجارى - بيروت. }
$$

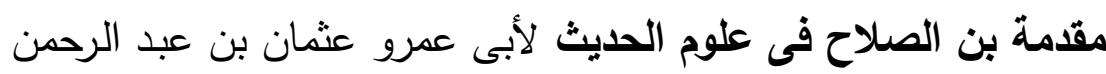

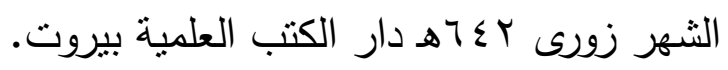

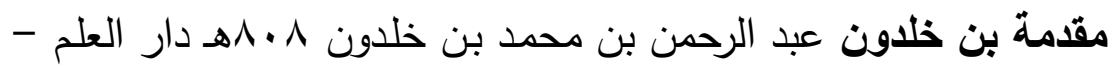

نـوادر الأصسول في معرفـة أحاديـث الرسـول نأليف الإمـام أبى عبد الله

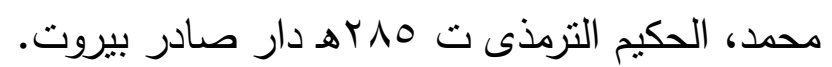

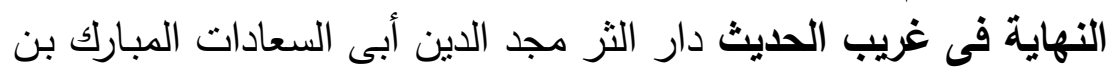
محمد الجزرى ت 7 . 7هـ - ط دار إحياء التراث العربى - بيروت. 


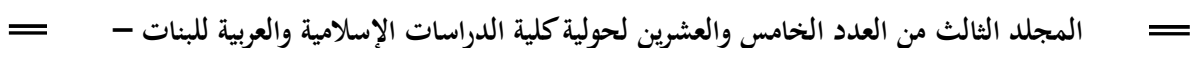

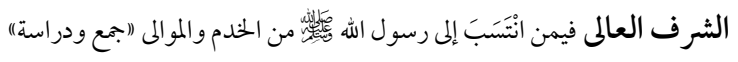

\section{فهرسر الموتهوعات}

VV

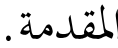

1)

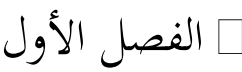

口ا المبحث الأول : المعنى اللغوى والاصطلاحى للولاء والموالى ................ 10 المبحث الثانى : كيفية معرفة الموالى وفوائد معرفتهم ل.......................

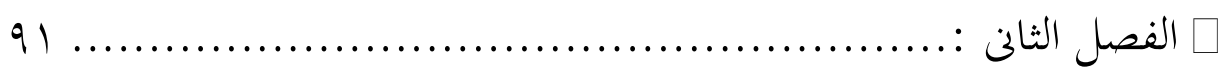

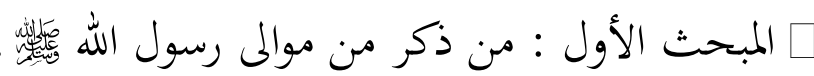

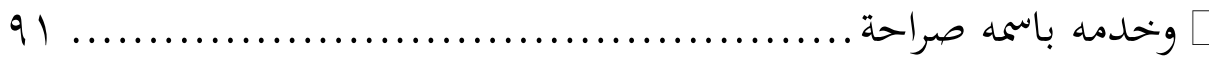

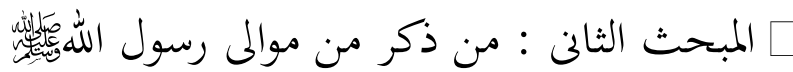

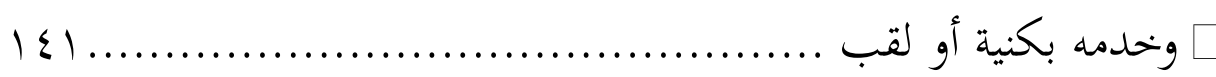

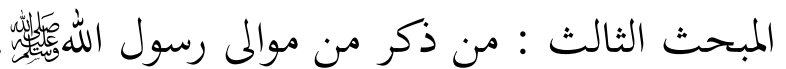

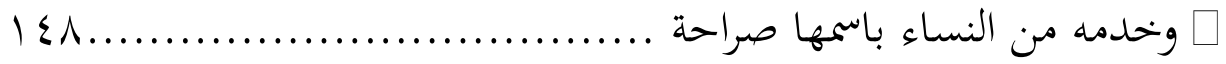

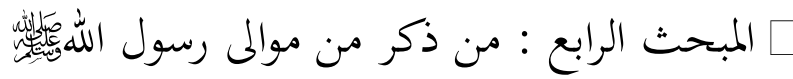

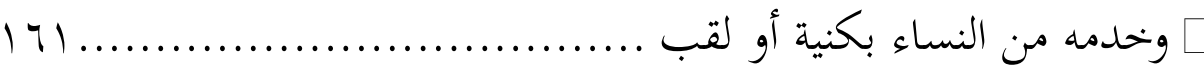
|

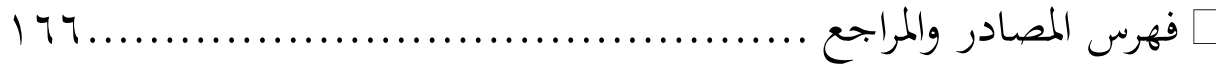
|

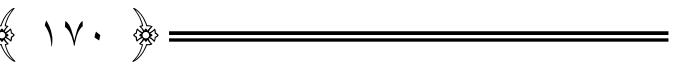

